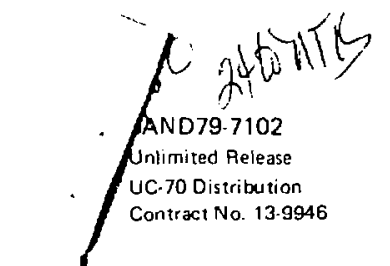

\title{
MASTER
}

\section{A Bibliography of Marine Radiation Ecology Prepared for the Seabed Program}

Vincent S. Schuitz

Washington State University

Zoology Department

Pullman, WA 99163

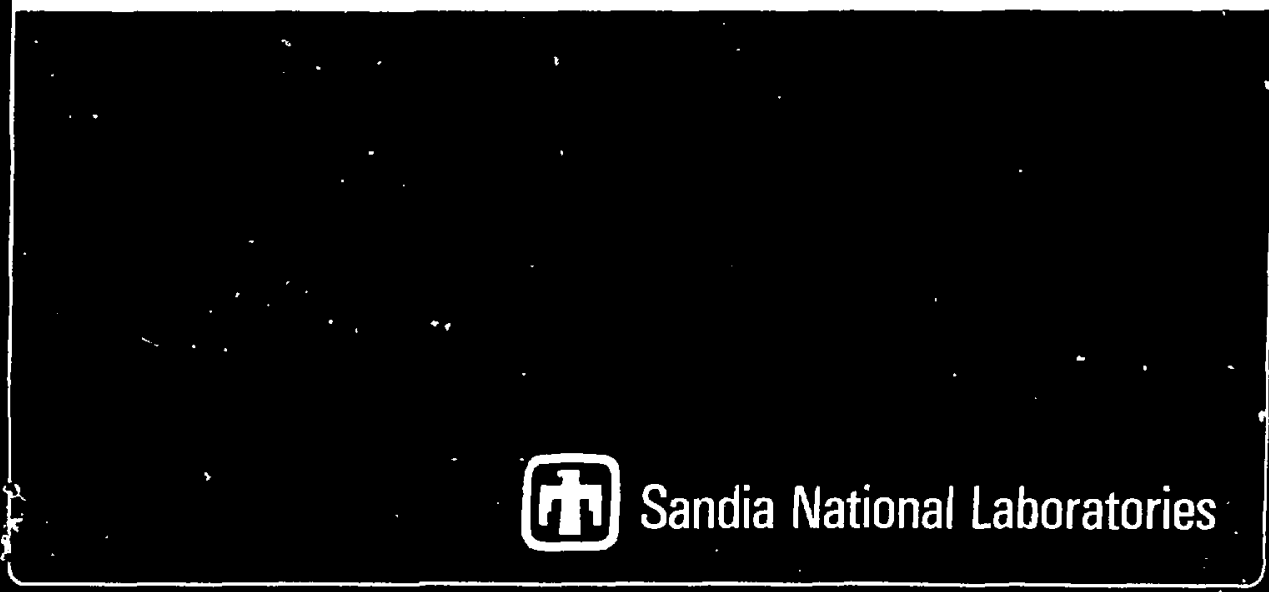


Issued by Sandia Laboratories, operated for the Unitod States Department of Energy by Sandiv Corporation.

\section{NOTICE}

This report was prepared as an account of work sponcored by the United States Government. Neither the United Strtes nor the Department of Energy, nor any of thair employees, nor any of their contractors, subcontretors, or thair employes, makes any warranty, express or implied, or aweumes any leal lisbility or responsibility for the sceurney, completeness or usefulness of any information, apparatus, product or process disclosed, or represents that its wis would not infringe privately owned rights.

Frimed in the United entus of Ameles

\section{Anilleilo from}

Nedenel Tcombual Informetion Corvios

U. 2 Depertument of Commores

cas Pon ford houd

erin,ilesd, VA 20101

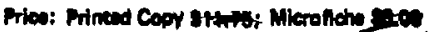

$$
\text { A } 14 \text { fol }
$$


SAND79-7102

UnIimited Release

Printed February 1980

\title{
A BIBLIOGRAPHY OF MARINE RADIATION ECOLOGY PREPARED FOR THE SEABED PROGRAM
}

\author{
Vincent S. Schultz, Compiler \\ Washington State University \\ Zoology Department \\ Pullman, WA 99163
}

1

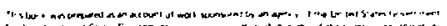

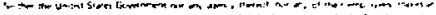

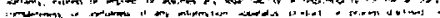

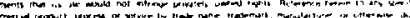

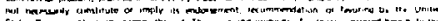

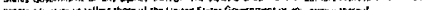




\section{PREFACE}

References on the effects of ionizing radiation on aquatic crganisms have been obtained from a number of sources. Many were obtained from reviews and other publications. Although the primary purpose of preparing this bibliography was to obtain information related to the nuclear wastes Seabed Disposal Biology Program of Sandia Laboratories, I included freshwater organisms as a matter of convenience and also with the belief that such a bibliography would be of interest to a wider audience than that restricted to the seabed Program. While compilation of a list in an area broad in scope is often somewhat arbitrary, an attempt was made to reference publications that were related to field or laboratory studies of wild species of plants and animals with respect to radiation effects.

In compiling this list, I have attempted to provide complete information concerning each reference without excessive library search. Since one often finds references listed in the literature that are incompletely cited, it was not always possible to locate the reference for verification or completion of the citation. I have included such references where they appeared to be of possible value. When known, a reference is followed with its Nuclear science Abstract designation, or rarely other abstract sources. Those desiring additional information should check Nuclear Science Abstracts utilizing the abstract number presented or other abstracting sources. In addition, the language of the article, other than English, is given when it is known to me. 
CONTENTS

$\underline{\text { Page }}$

Sources of Information on Marine Radiation

Ecology

7

Selected Review Articles on Effects of Ionizing Radiation on Aquatic Organisms

Effects of Ionizing Radiation on Aquatic

Organisms: A Bibliography

Ecological Modeling in Radiation Ecology:

Selected References

Aquatic Radiation Ecology: Selected References

on Dose and Dosimetry

Ecological Aspects of Radioactive Waste Disposal Into the Sea: Some General References

Effects of Ionizing Radiation on Aquatic

Organisms: Selected Tables

Selected Bibliographies on Biological Effects of Ionizing Radiation 


\title{
SOURCES OF INFORHATION \\ ON IUARIN RADIATION ECOLOGY
}

\section{by}

\author{
Vincent Schultz
}

The following selected 1lst of blblioeraphies, proceedings and books concerning or related to marine radiation ecology was prepared to aselst the reader interested in furthering $h \mathrm{~h}_{\mathrm{s}}$ knowledge of the subject.

For those publications that might be considered rather difficult to locate. I have given the Nuclear science Abstracts (NSA) citation number when known. All tities are presented in Engllsh, even thoueh the orifinal titie is in another language. If the publication is not available in English, the foreign language involved is indicated.

Aleksakhin, R. H. (ed.). 1977. Radioecology of Animals. hiaterials of I Ali-Union Conference. A. N. Severtsov Institute of Evolutional horphology and Ecology of Animals. "Nauke," Moscow, 266 pp. (In Ruesian).

Ancellin, J., P. Gueguenlat and P. Germain. 1979. Earine Radioecology. Study of Accumulation of Radionuclides Dicposed into the liarlne Environment and Applications to Radiation Protection. Ilbrairie de I'Enselgnement Technique, Farls. 272 pp.

Andrushaitis. G. P. (ed.). 1973. Redioecology of Water Orfanisme. Vol. 2. Distribution and litigretion of Radionuclides in Freshwater and Seawater Blocenoses. "Zlnatne:"Riga. 339 pp (Enclish tranel. 1975. AEC-tr-7606; iv, $194 \mathrm{pp}$ ), (NSA 30(8), 21082, 32(6), 14310 ). 
Andrushaltis, G. P. (od.). 1973. Radioecology of idater Organisms. Vol. 3. The iffects of Ionizing kadiation on ilater Organisms. "Zinatne." Riea. $156 \mathrm{pp}$. (EnElish trans 1.. 1974. AEC-tr-7529; ii, 95 pp.). (NSA 30(9): 24395; 31(5): 11691).

Anonymous. No date. Froceedings of the Seminar on harine Radioecology. Cherbourg, 3-6 Decembre, 1968. Oreanisation de Cooperation et de Developpenent Economiques, Agence Europeenne pour 1 'Energie ilucleaire, Paris. 153 pp. (In French) (NEA 24(17): 34204 ).

Anonymous. 1968. International symposium on the Application of Neutron Activation Analssis in Oceanography. Brussels, Belfium, 17-22 June, 1968. Institut Royal des Sciences Naturelles de Belgique. Bruxelles. $218 \mathrm{pp}$. (NSA 25(8), 15535).

Anonymous. 1972. harine Redioecology, The Cycling of Artificial Radionuclides Throuth liarine Food Chains. Proc. Second EITEA Seminar, Ilamour, Cermany, September 20-24, 1971. Organication de Cooperation et de Developpement Economiques. Faris. $209 \mathrm{pp}$. (In tenglish with English and French discussions) (iNA 29(1): 405).

Baranov, V. I. and I. M. Khitrov (eds.). 1964. Kadioactive Contamination of the Seas and Oceans. "Walka," icoscow. $224 \mathrm{pp}$. (Entrlish tranel.. 1964. JPRS 26.002 (Partial translation): 1966 . A 2 C-tr-664l; vi. 104 pp.). (NSA 18(19): 33779; $21(6): 8471)$.

Comnittee on the Effects of A tonic radiation on Cceanography and Fisheries. 1957. "'he Effects of Atomic sadiation on Oceanography and Fisheries. Fublica. 551. Nitional ncademy of siciences-National Research Council, Jashineton, DC. ix, $137 \mathrm{pp}$.

Egami, N. (ed.). 1973. Radionctivity and pishes (Contanination. Injury and Utilization). hoseisha-koseikaku Fubl. Co.. Tokyo, Japan. 398 pp. plus 2 plates. (In Japanesc) (specific articles: NSA 29(6): 1302313025; 13027; 16004; 16005).

Gromov, V. V. and V. I. Spitoyn. 1975. Artificial Radionuclides in the iarine invironment. Atonizdat, i.oscoir. $224 \mathrm{pp}$. (In Russian) (NISA 33(11); 26325). 
Hines, N. 0. 1962. Provine Ground, An Account of the Radiobiological studies in the Pacific, 1946-1961. University of Jashineton Press, Seattle. WA. xvil, $366 \mathrm{pp}$.

International Atomic Energy Agency. 1969. Disposal of Radioactive Wastes into seas. Dceans and Surface Waters. Froc. of a Symposium, Vienna, 16-20 liay. 1966. Vienna, Austria. Publication STI/PUE/126. (viii), $898 \mathrm{pp}$.

International Atomic Enerey Arency, 1970. Reference hiethods for hiarine Radioactivity Studies. Vienna, Auetria, Tech. Repts. Series No, 118. (vi), 284 pp. (STI/DCC/10/118).

International Atomic Energy Apency. 1973. Rajioactive Contamination of the liarine Envircnment. Proc. of a Symposium held in Seattle, inshington, USA, 10-14 July, 1972. Vienna, Austria. Fublication STI/PUB/313. (xi1), $786 \mathrm{pp}$.

International Atomic Energy Agency. 1975. Design of Radiotracer Lxparinients in larine Eiological Systems. Vienna, Austria, Tech; Repts. Series No. 16?. (v), $289 \mathrm{pp}$. (STI/DOC/167).

International Atomic 5nergy Agency, 1975. Reference lethods for larine Radioactivity Studies II. Vienna, Austria, Tech. Repts. Series No. 169. (v), 239 pp. (STI/DCC/10/169).

International $\Lambda$ tomic Enezgy Agency, 1976. Iffecte of Ionizing Radiation on Aquatic Orfanisms and Ecosystems. Vienna, Austria, Tech. Repte. Series No. 172. (vi1), 131 pp. (STI/OCC/10/172).

International Atomic Energy Agency. 1979. Methodology for Assessing Impacts of Radioactivity on Aquatic Ecosystems. Vienna, Austria, Tech. Repts. Series No. 190. (v), 416 pp. (STI/DOC/10/190).

Ostroumov, E. A. (ed.), 1975. Chemical Analysis of karine Sediments; "Nauka," Hoscow. 260 pp. (In Russian) (NSA 33(5), 8847).

Panel on Radioactivity in the Environment. 1971. Radionetivity in the Marine inviroming. Nationnl Acndemy of Eeiences, Wowhinelon, LL. Ix, 27a M.

Pertsov, L. A. (ed.). 1971. harine Kadioecolory. Atlanticheskiy Hauchno-Issledovatel'skiy Institut Rybnog, Khozyaistva 1 Okeanoernfly, Kaliningrad, USSR. Issue 44. $132 \mathrm{pp}$. (In Russian) (NSA 30(1), 3il). 
Fertsov, I. A. (ed.). 1971. Jiarine Radioecology. Atlanticheskiy Nauchno-Issledovatel'skiy Insiitut Rybnogo Khozyaistva i Okeanografiy, Kalinigrad, USSR. Issue 45. 85 pp. (In Russian) (ISA 30(1): 312 ).

Pol1karpov, G. G. 1966. Radioecology of Aquatic Organisms: The Accumuiation and Biological Effect of Radioactive Substances. English translation and revised edition: $\checkmark$. Schultz and A. W. Klement, Jr.., eds. COriginal: 1964. Radioecology of larine organisms. Atomizdat, Moscow, 295 pp.). North-Holland, Amsterdam, xxviii. 314 pp. (NSA 18(19), 33230; 21(12): 20115).

Polikarpov, G. G. (ed.). 1970. Warine Radioecology. "Naukova Dumka," Kiev. 276 pp; (EnElish transl. 1972. AEC-tr-7299; v, 348 pp.). (NSA 25(15): 35117 ; 26(10): 23186).

Polikarpov, G. G. (ed.). 1972. Radiation and Chemical Ecology of Aquatic Organisms. "llaukova Dumka," Kiev. $118 \mathrm{pp}$. (In Russian) (iNSA 26(22): 53532).

Polikarpov, G. G. (ed.). 1974. Chemoradioecology of the Pelagic and the Benthic Zones. (i.etals and Radionuclides in rquatic Oreanisms and Environnent). "Naukova Dumka," Kiev. 271 pp. (In Russian) (NSA $30(11): 29422)$.

Polikarpov, G. G. (ed.). 1975. Radiochemo-ecological Investigations in the liediterranean Sea. "Naukova Dumka." Kiev. $88 \mathrm{pp}$. (In Russian with English summaries).

Polikarpov, G. G, and I. S. Risik (eds.). 1977. Fadiochemoecology of the Black Sea. "Naukova Dumka," IKiev. $231 \mathrm{pp}$. (In Russian).

Polikarpov, G. G., Yu. P. Zaitsev, I. G. Kulebakina, V. I. Timoshchuk, V. G. Tsytsueina, L. I. Rozhanskaya, N. S. Risik, A. A. Strogonov and A. Ya. Zesento. 1970. Radioecological Investications of the fiediterranean Sea. "Naukova Dumka," kiev. 231 pp. (In Russian) (NSA 25(5): 8630).

Fruter, A. T', and D. I. Alverson (eds.). 1972. The Columbia River Estuary and Adjacent Ocean Waters: Bioenvironmental Studies. Univ, of Washington Fress, Seattle, WA. $\times 1 i 1,868 \mathrm{pp}$. 
Shvarts, S. S. (ed.). 1971. Problems of the Radioecology of Aqueous Organisms. Symposium held at liiass, lisir. July 10-15, 1968. Tr. Inst. Ekol. Fiast. Zhivotn. 78: 1-240. (In Russian) (NSA 26(12): 28093 ).

Shredov, V. P. and S. A. Patin. 1968. Radioactivity in the Oceans and Seas. Atomizdat, hoscow. 28 pp. (In Russian) (NSA 22(24): 51122).

Small. S. H. (ed.). 1963. Nuclear Detonations and llarine Radioactivity. The report of a symposium held at the Norwegian Defense Research Éstablishment 16-20 Septcmber, 1963. Norwegian Defense Research Listablistinent, Kjeller, Norway. $221 \mathrm{pp.}$ (In English) (iNSA 19(13): 24714).

Sokolova, I. A. 1971. Calcium, Strontium-90, and strontium in wierine Grganisms. "Naukova Dunka." Kiev. $240 \mathrm{pp}$. (In Russian) (NSA 26(18): 43396).

Sorokin, B. F. (ed.). 1971. Effect of Ionizing Radiation on the Orcanicm. The Froblem of the iffect of Fadioactive Water Follution on the keprociuction of Comnercial Fishes. Tr., Polvar. Nauchno-Issledovatel'skiy Ins ti tut Rybnofo Khozyaistva i Okeanografiy. No. 20: 1-182. (English transl... 1973. AliC-tr-7418; ii, 217 pp.). (NSA 2?(12): 27944).

Tsytsugina, V. L., N. S. Risik and G. E. Lazorenko. 1973. Artificial and Natural Radionuciides in liarine Life. "Naukova Dumka," Kiev. 152 pp. (English transl., 1975: TT 75-50010; vi, 115 pp.). (NSA 28(7): 15818; 29(9): $21246 ; 33(8): 17173)$.

Zoological Station of Naples, Italy. 1959. harine Biological Applications of Rario-isotope kesearch Techniques. Symposium held in Naples. Italy, Septeinber 15-28, 1957. Fubblicazioni Stazione zoologica Napoli 31(suppl.): (i), 189 pp... 7 plates. (In inglish). 


\section{Bibliographies :}

Deutsches Hydrographisches Institut. 1967. Bibliocraphics in nuclear science and technology. Section 25: liaritine radioecolory. Zentralstelle fur AtonkernenereiDokumentation, Frankfurt/irain. Gersiany. Report AEDC-25-01, iv, $41 \mathrm{pp} . ;$ 1968, ALD-C-02, viii, 35 pp.i 1973. AED-C-25-03, iii, 65 PB. 1973, AED-C-25-0l, iii, $85 \mathrm{pp}$. (Various languages) (N5A 22(2): 2254: 29(8): $18354,18355)$.

Edmundson, E., Jr., V. Schultz and A. W. Klement, Jr, 1969. Hiarine radioecology: A selected bibliography of non-Russian literature. 'U. S. AEC report TID-3917. i, $127 \mathrm{pp}$.; 1972, TID-3917 (Suppl. 1), i, 76 pp.; 1974, TID-3917 (suppl. 2), i. $53 \mathrm{pp}$.

Klement, A. $\mathrm{H} ., \mathrm{Jr}$. and V. Schultz. 1972. Russian radioecology: A bibliography of soviet publications with citations of Englioh translations and aostracts. U. S. AEC report TID-3915 (Suppl. 1). iii, 66 pp.

Klement, A. W. Jr. and I. E. Vallen. 1963. A selected list of references on marilie and aquatic radiobiology. pD. 729-7l+6. In: $V$. Schultz and $A$. if klement, ir. (eds.), Radioecology. Reinhold, NY. (Also: 1960. U. 3. AEC report TID-3903; 42 pp.).

Klement, A. W., Jr., C. F. Iytle and V. Schultz. 1968. Russian radioecology: A bibliography of Soviet publications with citations of English translations and abstracts. U. S. AEC report TID-3915. iv, 131 Pp.

Lattimer, J. ji. 1970. Estuarine radioecology, A biblioEraphy of report literature. Office of Library services, U. S. Dept. of Interior, Hashington. DC, Biblio. Series No. 16. iii, $52 \mathrm{pp}$.

O'Leary, J. M. and I. C. Foberts. 1962. Disposal of radioactive wastes into marine and fresh waters. International Atomic Energy Agency, Vienna, Austria. Biblio. Series No. 5. 365 pp. (STI/PUB/2l/5).

Polikarpov, G. G., ed.; Z. Ifi, Exuz 'yan, V. N. Yegorov and N. V. Kurilova, compls. 1974. Bibliographica.l index of publications of Institute of Biology of South Seas AS Ukr. SSR on the problem of "radiation and chemical ecology" (1957-1972). "Naukova Dumka," Kiev. 58 pp. (In Russian) (NSA $30(9): 24150$ ).

Schultz, V. 1976. Russian radioecolory, A bibliocraphy of Soviet publications with citations of English translations and abstracts. U. S. IRDA report TID3915 (Suppl. 2). v. 80 pp. 
Schultz, V. and F. W. Whicker. 1971. A selected bibliography of terrestrial, freshwater and marine radiation ecolocy. U.S. AEC report TID-25650. iv, 185 pp.; 1975. U. S. ERDA report TID-25650-Si, iii, 240 pp.

Triulzi, C. 1977. Scientific activities of the members of the inarine Padioactivity Comittee and related bibliography (1973-1976). Rapp. Comm. int. lier fiedit. 24(3): $107-158$.

Various authors. 1978. Radioactivity in the sea. pp. 247-429. In: Geochemical study of the Ocean and the A tmosphere. Yasuo liikake Seventieth Anniversary. (Collected papers (1939-1977) publishied by Geochenical Laboratory, weterological Research Institute, Tokyo, Japan). xili, $850 \mathrm{pp}$. 
SELECTED REVIEW ARTICIES

ON EFFECTS OF IONIZING RADIATION ON AQUATIC ORGANISNS

$$
\text { by }
$$

Vincent Schultz

$$
\begin{aligned}
& \text { Department of Zoology } \\
& \text { Washington State University } \\
& \text { Pullman, Washington } 99164
\end{aligned}
$$

1979 
Aleksakhin, R. 3. 1973. Achievements and some actual tasks of water radioecology. pp. ?-19. In: Radioecology of water creanisms. II. Distribution and f.ipration of Radionuclides in Freshwater and Seawater Biocenoses. (G. P. Andrushaitis, ed.). (Enelish trans1. AiE-tr-7606). (NSA 30-21354).

Altukhov, Yu. F., A. N. l.ilishnikov and T. A. Novikova. 1977. Analysis of genetic structure of parthenogenetic populations as a method of elucidation of mutagenic activity of the environment. pp. 70-71. In: Radioecology of Animals. (R. h. Aleksakhin, ed.). "Nauka," lioscow. (In Russian).

Andrushaitis, G. F. (ed.), 1973. Radioecology of water Organisms. Vol. 3. The iffects of Ionizinf Radiation on water Organisms. "Zinatne," Pifa. $156 \mathrm{pp}$. (inËlish transl. AEC-tr-7529).

Anonymous. 1967. liarine radioecolofy: Current research and future scope. Intern. Atomic Enerey Agency, Vienna, Austria. vi, $125 \mathrm{pp}$. (CII/RiL/105).

Blaylock, B. G. 1974. Effects on aquatic biota of radioactive effiuents from nuclear power stations. Trans. Amer. Nucl. Soc. 18: 46-47, (NSA 30-15372).

Elaylock, B. G. and J. R. I'rabalka. 1978. Evaluatine the effects of ionizine radiation on aquatic oreanisms. Adv. Radiat. Biol. 7: 103-152.

Blaylock, B. G. and J. E. Wi therepoon. 1978. Evaluation of radionuclides released from the light water reactor nuclear fuel cycle to the aquatic environment. op. 851-865. In: Environmental Chemistry and Cycline Processes. (D. C. Adriano and I. L. Brisbin. Jr., eds.). $U_{0} \approx$. DOE report CONF-7604;29. (DOE ¿ymp. Series 45 ).

Bowen, V. T.. J. S. Clsen, C. I. Osterbere and J. Ravera. 1971. Chp. 8. icological interactions of marine. radioactivity. pp. 200-222. In: Radioactivity in the Jarine invironment. National kesearch Council National Academy of Sciences. Washineton, DC. 
Butler, E. G. 1936. The effects of radium and $x$-rays on embryonic development. pp. 389-410. In: Bioloeical Effects of Kadiation. (B. M. Dugear, ed.). ickrawHill, NY.

Bychkovskaya, I. B. 1966. Dynamics of lethal radiation effects in various bioloeical species. kadiobiologiva 6(1): 39-45. (Enflish transl. Aic-tr-6770). (Frimates, rodents, insects, crustaceans, infusoria).

Chipman, w. a. 1972. Ionizine radiation. pp. 1579-1657. In: Vharine icolocy, Volume I, Fart 3. (C. Kinne, ed.). Wiley-Interscience, HY.

Curtis, H. C. 1936. iffects of $x$-rays and radium upon regeneration. pp. 411-457. In: Ejological iffect. of Radiation, vol. I. (B. li. Dugfar, ed.). i.cc raw:ill Book Co.. NY. (Forifera, Hydrozoa, Turbellaria, Nemertina, Chaetopoda, Iunicata, Amphibia).

Cushine, C. i. 1970. kadiation ecoloey in freshwater communities. pp. 45-56. Int iian and Aquatic Communities. water Resource: Research Institute, Orcfon itate University, Corvallis. (Also: Battelle Northwest Lab;, U. S. AEC report BNWL-SA-3291). (CONF$700554-1)$. (NiA 25-24073).

Davies, D. R. and H. J. Evans. 1966. The role of frenetic damage in radiation-induced cell lethality. $l_{d}$ dv. Radiat. Biol. 2: 243-353. (Includes alfae and proto20a).

Donaldson, L. R. 1960. Panel summary on the effects of the discharge of radioactive materials on aquatic life. pp. 40-41. In: Bioloeical Froblems in fater Follution. (C. W. 'iarzwell, comp.). U. i. Fll , R. A. Taft Sanitary Engineering Center, Cincinnati, OH. Tech. Rept. $160-3$.

Donaldson, I. R. 1964. Evaluation of radioactivity in the marine environment of the Facific provine cround. pp. 73-83. In: Nuclear Detonations and harine Radioactivity. ( $\mathrm{i}$. H. Small, ed.). Norwegian Defense Pesearch biablishment, ijeller, Norway. 
Jonaldson, 1. K. and R.F. Foster. 1957. Lffects of radiation on aquatic oreanisms, pp. 96-102. In: The iffects of Atomic Radiation on Oceanoeraphy anc isheries. National Academy of uciences - liational Research Council, Washineton, DC. Fublication 551.

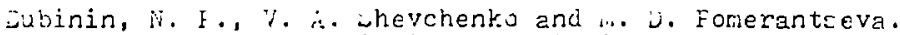
1971. Hife: of ionizine raciation on population: (radiation-genetic aspecte). pp. 183-228. In: Contemporary Froblems of Radiobiology. Volume 2: kadioecology. (v. … klecriovekiy, G. S. Folikarpov and $r$. i.. Eleksakhin, eds.). ftomizdat, loocow. (nish tranel. creenbers, $2 .$. ed. 1973. Radicecolocy. john Wiley, WY. pp. 157-196).

limball, $k . \vec{F}$. 1952. Cenotic effects of radiation. Ann. zev. inclear aci, 1: 479-49,4.

i.imball, $\because F . F$. 1955. The effecte of radiation on protozoa and the eros of invertebrater other than insects. ny. 285-33i. In: Vol. 2, kadiation Biology. (A. hollaender, ed.;. i.ceraw-till Book Co., NY.

lineldorf, D. $\therefore$, and $\therefore$. L. Funt, 1965. Ionizine Radintion: iteural Function and Behavior. Academic irter, in. xil, $331 \mathrm{pp}$. (Includes data on insects, frops, pienaria, darhnia, enaile, fish, crád, turtle).

liulikov, iv. $v$. 1970. On action of radionuclides upon hydrobionte. pp. 3- . In: istion of Ionizing Radiatione on Hydrobionts and Iand Flante. Firudy Instituta jhol or ii Rasteniy i zhivotngkh 7\%. (In suseian).

Kulikov, iv. $v$. 1071, jadioecolory of freshwater plants and animals. $\mathrm{pp}$. 367-38\%. In: contemporary trobleme of Radiobiolory. Volume 2: zadioecology. (V. ... :Iechkovakiy, G. G. Folikarpov and F. l... Aleksairhin, eds.). itomizdat, loscow. (Enflish transi. Creenbere, D., ed. 1973. Fadioecology. John wiley, NY. r,p. $323-337)$.

Lcs, 2.2 1955. Actions of Radiations on livine Cells. ( $r \in \mathrm{v}$. ed.). Cambridé liniv. iress, London. $416 \mathrm{pp}$. 
i:occati, A. F. and R. C. Frdmann. 1973. Fossible effects of ionizine radiation on marine life and the subsequent impact on man. Trans. Amer. Hucl. - oc.. iuppl. 16(1): 18-19. (WNA 28-12869).

lioscati, A. F. and R. C. irdmann. 1974. Fossible effects of ionizine radiation upon marine life and some implications of postulated accidental releases of radioactivity. Nucl. Technol. 22(2): 184-190. (NSA 30$6546)$.

Newcombe, li. 3. 1971. jhe renetic effects of ionizins: radiations, Adv, Genetics 16: 239-303.

Cphel, L. L. et al. 1976. Cho. 2. Iffects of ionizinf rediation on aquatic orcaniems. pp. 57-86. In: iffects of Ionizing liadiation on Aquatic Orfanisne and Ecosyetems. Intern. Atomic energy Acency, Vienn, Austrja, Tech. Repts. .eries ijo. 172.

Eolikarpov, G.G. 1966. Fart III. 'lhe effect of nuclear radiation on marine or Earistns. pp. 183-249. In: Radioecolory of Aquitic Creanisms: The Accumulation and iffect of Radioactive Substances. Enrlish trarslation and revised edition. $V$. Echuliz and $A$. $i$, Hilement, Jr., eds. North-Holland, insterdan. (Orieinal: 196\%. Radioecolony of itarine oreaniems. Atomizdat, ioscon, $295 \mathrm{pp}$.$) .$

Folikarpov, G. G. 1967. Frobleme relatine to the radioecolory and chemical ecolory of marine organisms. ckeanologiya 7. (Entish transl. pp. 435-443). (ives $23-38517$ ).

jolinarpov, G. G, 1967. Radioecological investifations in seas and oceans. Radiobiologiya 7(5): 801-El2. (English transl. AiC-tr-6954). (Nis 22-28396).

Iolikarpov, G. G. 19?0, Unsolved problems of water radioecology. Radiobiologiya 10(2): 242-252. (inelish transi. ALC-tr-7171). (N.A 24-39473).

Folikarpov, G. G. 1977. Effects of ionizing radiation upon aquatic oreanisms (chronic irradiation). pp. 25-46. In: Atti della Cionnata iul Tema Alcuní Aspetti di Radioecoloria. XX Coneresso iationalc, fssociazione Italiana di Pisica Sanitaria e Frotezione Contro le Radiazioni. Bologna. 
Preston, A., D. S. Woodhead, N. T. Hitchell and R. J. Pentreath. 1971. Impact of artificial radioactivity on the oceans and on oceanography. Proc. Roy. Soc. Edinburgh, Sect. B $72(41), 411-423$. (NSA 27-7803).

Rice, T. R. and J. W. Angelovic. 1969. Radioactivity in the sea: Effects on fisheries. pp. 574-578. In, Encyclopedia of liarine Resources. (F. E. Firth, ad.) Van Noctrand Rpinhold, NY.

Rice, T. R. and J. P. Baptist. 1970. Ecological aspects of radioactivity in the marine environment. pp. 107176. In: Environmental Radioactivity Symposium. (J. C. Clopton, ed.). Dept. of Geography and Environmental Engineering. The Johns Hopkins Univ., Baltimore, liD.

Rice, T. R. and D. A. Wolfe. 1971. Chp. 12. Radioactivity--chemical and biological aspects. pp. 325-379. In: Impingement of han upon the Oceans. (D. W. Hood, ed.). John Wiley, NY.

Rice, T. R., J, P. Baptist, F, A. Cross and T. W. Duke. 1972. Potential hazards from radioactive pollution of the estuary. pp. 272-276. In: larine Pollution and Sea Life. (M. Ruivo, ed.). Fishing INews Itd.. London.

Rugh, R. 1953. Vertebrate radiobiology: Imbryology . Ann. Rev. Nuclear Sci. 3: 271-302. (NSA 8-978). (Fish, amphibia, chick, mammal).

Rugh, R. 1959. Vertebrate radiobiology (embryology). Ann. Rev. Nuclear Sci. 9: 493-522. (NSA 13-11444). (Includes marine organisms, fish).

Rugh, R. 1960. General biology: Gametes, the developing embryo, and cellular differentiations. pp. 1-94. In, Hechanisms in Radiobiology, Vol. II. (M. Errera and A. Forssberg, eds.). Academic Press, NY.

Schroder, J. H. 1979. Methods for screening radiation-induced mutations In f1sh. pp. 381 - L02. In: Yethodolog for Assessing Impacts of Radioactivity on Aquat1c Ecosystems. Intern. Atomic Energy Agency, Vienns, Austrla, Tech. Repte. Series No. 190.

Seymour, A. H. 19?l. Chp. 1, Introduction. pp. 1-5. In: Radioactivity in the Marine Environment. National Research Council - National Academy of Sciences, Washington, DC. 
Seymour, A. H. et al. 1975. Aquatic environnent. pp. 103-161. In: Iong-term Worldwide iffects of iucleardeapons Detonations. (Committee to itudy the ioneterm vorldwide iffects of iuclear-ieapons jetonatione;. National Research Council - Hational fcademy of iciences, iashinfton, DC.

spitsyn, V. I. 1960. Comment of panel discussion No. 6 , effects of radiation on marine orfanisms. In: Disposal of Radioactive Wastes, Vol. 2. Intern. Atomic inerry Afency, Vienna, Austria, publication $\mathrm{II} / \mathrm{YUJ} / 18$.

Stannard, i. iv. 1973. Toxicology of radionuclides. frnn. Rev. Fharmacol. 13: 325-357.

ilempleton, $d$. L. 1976. Effecte of radiation on aquatic populations, pp. 287-297. In: Environmental roxicity of Aquatic Radionuclides: wodels and wechanirne. (in. I. billor and J. iv. Stannard, eds.). Ann hrbor icience Publ.. Ann arbor, i.i.

'Fempletor, i. I., K. Ĺ, Nakatani and E. L. ield. 1971. Chp. 9. Radiation eifects. pp. 223-239. In: incioactivity in the ilarine invironment. National jesearch Council - Vational Academy of Sciences, Washinetor, $\mathrm{LCC}$.

I'empleton, W. I., K. I. Wakatani and E. E. Held. 1972. iffects of radiation in the marine ccosystem. $p$. 353-355. In: diarine follution and Sea Iife. (1... Ruivo, ed.). Fishine News Itd., Iondon.

Fempleton, $/$. L. et al. 1976. Zffects of ionizing radiation on aquatic populations and ecosystems. pp. d?100. In: iffects of Ionizine Radiation on Aquatic Orfanisms and Ecosystems. Intern. Atomic inerey Agency, Vienna, Austria, Tech. Repte. Veries Vo. 172.

Turner, F. B. 1975. Effects of continuous irradiation. on animel population. Adv. Radiat. Biol. 5: 83-144. (vi:A 32-28299).

iolfe, D. A. and T. R. Rice. 1968. iafe levels of radioactivity in aquatic enviroments. Scientia (ivilan) $103(9-10): 469-487$. (NSA 23-22317). 
joodhead, J. S. 19?1. Biological effects of radioactive vaste. Froc. Roy. Soc. (Iondon) Bl77: 423-437. (NSA 25-42373).

2ajteev, Yu. F, and G. G. Folikarpov, 196't. The probleme of radioecoloey of hyponeuston. Okeanoloeiya 4(3):

423-430. (Enelish transl. JPFi 25.966). (NSi 19-22). 
EFFECTS OF IONIZING RADIATION ON AQUATIC ORGANISMS,

A BIBLIOGRAPHY

by

Vincent schultz

Department of $200100 \mathrm{By}$

Washington State University

Pullman, Washíngton, 99164

2979 


\title{
PREFACE
}

References on the effects of ionizing radiation on aquatic oreanisms have been obtained from a number of sources. Many were obtained from reviews and other publications. Although the primary purpose of preparine this bibliography was to obtain information related to the nuclear wastes Seabed Disposal Biolozy Program of Sandia Laboratories, I included freshwater organisme as a matter of convenience and also with the belief that such a bibliography would be of interest to a wider audience than that restricted to the Seabed Program. While compilation of a list in an area broad in scope is often somewhat arbitrary, an attempt was made to reference publications trat were related to field or laboratory studies of wild species of plants and animals with respect to radiation effects.

In compiling this list, I have attempted to provide complete information concerning each reference wi thout excessive library search. Since one often finds references listed in the literature that are incompletely cited, it was not alway possible to locate the reference for verification or apletion of the citation. I have insluded such references where they appeared to be of possible value. When known, a reference is followed with its Nuclear Science bstract designation, or rarely other abstract sources. Those desirint additional information should check Nuclear Science Abstracts utilizing the abstract number presented or other abstracting sourses. In addition, the language of the article, other than English, is given when it is known to me.

\section{ACKNOWLEDG EMENTS}

Typing and editorial assistance of Patricia L. Schultz is eratefully acknowledeed. Drs. L. S. Gomez and M. G. Viarietta of Sandia L-boratories provided the stimulation to accomplish this task.

\section{Symbols}

AEC-tr- U. S. Atomic Enerey Comission translation

BA

Blological Abstracts

CA

\author{
Chemical Abstracts
}


CONF

EPA

ERA

JPRS

NP

NSA

NTIS

ons

STI/PUB/

TT -

U. S. AEC

U. S. ERDA

U. S. DOE
U. S. AEC conference designation

Environmental Protection Agency (U. S.)

Energy Research Abstracts

Joint Publications Research Service, New York (See also TT-)

Report numbers assigned by U. S. AEC for non-AEC reports

Nuclear Science Abstracts

National Technical Information Service, Springfield, YA. 22151 (formerly CFSTI)

Office of Technical Services, U. S. Department of Commerce, Washington, DC. 20230

(Most reports listed are now available through NTIS instead of OTS.)

International Atomic Energy Agency order numbers

OTS and NTIS order numbers

United States Atomic Enerey Commission

United States Enerey Research and Development Administration (formerly U. S. AEC)

Un:ted States Department of Enerey

Dr. G. G. Polikarpov. Institute of Biology of South Seas, Sevastopol, and his many colleagues in the USSR, for contribution to our knowledge of marine radioecology. 
I. PIANTS -... 1

A. ALGAE - 1

1. Chlorophyceae $\ldots 1$

Acetabularia - 1

Chlamydomonas - 1

Chlorella 7

Desmid - 18

Oedogonium 18

Scenedesmus - 20

Others

2. Charaphyceae - 24

Chara - 24

Nitella - 25

Nitellopis $\ldots 26$

3. Euglenophyceae - 27

Euglena - 27

4. Bacillariophyceae - 30

5. Dinophyceae - 31

6. Cyanophyceae - 31

Anabena - 31

Anacystis 32

Others - 34

7. Miscellaneous 
B. FUNGI - 38

1. Phycomycetae -.. 38

C. "HIGHER" PLANTS - 39

II. ANIMALS - 42

A. INVERTEBRATES - 42

1. Protozoa - 42

Amoeba - 42

Blepharisma 46

Colpidium - 47

Colpoda - 47

Euploteg - 48

Paramecium - 49

Spathidium - 65

Stentor

Tetrahymena - 66

Others - 67

Miscellaneous - 68

2. Coelenteratg 69

Hydra - 69

Planaria - 71

3. Rotifera

4. Mollugag - 75

5. Annelida - 82

Nereis 
6. Arthropoda - 83

Artemia -

Asellus -

Cladocera - 89

Decapoda -- 91

Insects -.... 93

Limulus

Lirceus -.... 94

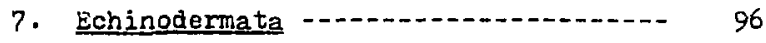

Sea Urchin - 96

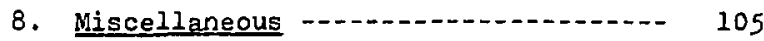

B. VERTEBRATES - 112

1. Fishes - 112

2. Amphibians - 161

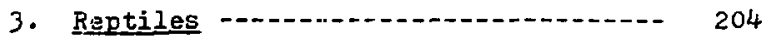

Turtle - 204

4. Miscellaneous -...... 204

III. MISCELIANEOUS --..- 205 


\section{FLANLS}

A. ALGAE

\section{Chlorophyceae}

(Acetabularia)

Sacq, Z. i..., F. Vanderhaeghe, J. Damblom, 1.. Errera and A. herve. 1957. Effets des raone $X$ sur Acetabularia mediterranea. Exptl. Cell Res. 12(3): 639-t48.

Eonotto, S. and $\bar{\kappa}$. Kirchmann. 1972. One particular type of abnormal morphogenesis arising from the eama irradiation of Acetabularia mediterranea. G. Sot. Ital. 106(1): 21-27. (In French) (NSA 27-20036).

Errera, .... A. Hicq, R. Lofan, Y. Ekreb and ${ }^{*}$. Vander haeghe. 1958. 'The effect of radiation on nucleo. cytoplasmic relations in livine cells. froc. 2nd Uis Intern. Conf. on the Feaceful Uses of Atomic inerey 22: 475-178. (Amoeba, Acetabularia).

Kirchman, H. J. and s. Bonotto. 1973. Effects biologiques et biochimiques des rayonnements ramma sur 1 algue marine scetabularia mediterranea. pp. 527541. In: Radioactive Contamination of the sarine invironment. Intern. Atomic Energy Agency, Vienra,

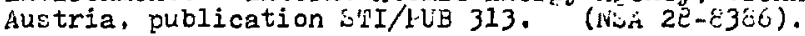

Cichter, G. 1959. Behaviour of FNA and colutle cyto. plasmic proteins in U.V. irradiated nucleated and non-nucleated cells of Acetabularia. 2. Naturforsch. 14b: 100-104. (In Germen).

ix, $\vec{E}$. 1958. The effect of radiation on Acetabularia. III. The effect of $x$-radiation and ultraviolet radiation on the nucleated part of Acetabularia

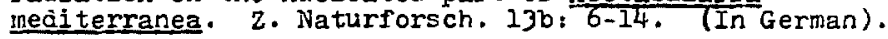

(Chlamydomonas)

Arnola, C.-G. and H. Ranneberg, 1967, Nonreciprocal recomination in Chlamydomonas reinhardi. Ber. Deut. Eot. Ges. 80: 512-516. (In German) (Nis 23-26760). (Gamma irradiation). 


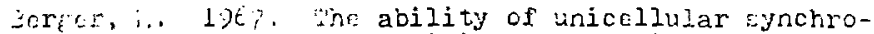
nized volvosajes to divide after $x$-irradiation. Intern. J. Keniat. 3ioi, la(5): 477-486. (In Garian;. (igematococcus pIuvialis, Chiamydomonas spp.).

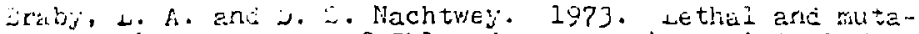
Cenic res ivase: of Ghlawiononas reinherdi to 1.55

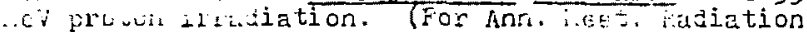
Rec. Loc., St. Louis, i.issouri, Aprii 29, 1973j.

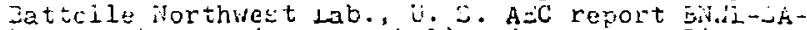
4531. Il; Ej. (CCNF-730431). (THA 2E-593E).

zmant, 上. $\therefore$ 196e. Lurvival after iractionated coses of radiation: nodification by aroxia of the responce of irlandomonas. Nature 219(5149): 75-77.

- want, 1. $\therefore$ 1370. Lffect of hypoxia on recovery from tublethal diame $c$ in Chlamionomas. Intern. j. Fadiat. 3iol, 17(6): 533-539. (itS 25-8795). (ilectron team).

-ryant. $\therefore$. 1972. Chance in sencitivity of cell: iurini" exposure to radiation at low dose ratc. Intern. $u$ tadiat. Biol. 22(1): 67-73. (NiA 2645754). (chlemydomonas).

zryant, i. - i. 1973. Lii as a ceterminant of oxyen enhancement ratio and shape of curvival curve for Chlaydomones, Intern, j. Radiat. $3101.23(3): 217-$ 220. (Nit $28-5934)$.

Eryant, $-\therefore$ I974. Chance in senritivity of cells after eplit dose recovery. A further test of the repair jo othesis. Irtern. J. :adiat. Dioi. 26(5): 499-504, (itit 31-22934). (Ehlanidomonas reinhardij).

Grant, i. $\therefore$ and id Farker. 1978. Absence of repair of aublethal U.V. lieht damare in Chlamydomonas. intern. J. Raciat. jiol, $3+(3): 273-278$.

Cochace!s, 2 . and $J$. Billova, 1970. JNA synthesic and chary es ir radiosensitivity aurinc the cell cjcle of veretative culture of chlamydomonas reinhardis. Intors. v. adiat. Biol. 17(2): 127-134. Tiva $24-34760)$. 
Davies, D. R. 1965. Repair mechanisms and variations in UV sensitivity within the cell cycle. l.utat. Res. 2(6): 477-486. (NEA 20-12687). (Chlamydomonas reinhardi).

Javies, D. F. 1966. Acriflavine inhibition of dark repair and late Eeneration death. Biochem. Biophys. Res. Commun. 23(5): 652-659. (iNA 20-38611). (UV-irradiation, chlamydomonas reinhardi).

Davies, D. R. 1966. Fatterns and rates of recovery in synchronous populations of aleal cells exposed to Eama-radiation. Radiation Res. 29(2): 222-235. (Chlanydomonas reinharai).

Lavies, D. R. 1968. Radiation studies on meiotic cells of Chlamydomonas reinhardi: pp. 123-133. In: Effects of Radiation on jieiotic systene. Intern. Atomic Inergy AEency, Vienna, Austria, publication STI/E-UB-173. (NSA 24-21322).

iavies, D. T. 1969. The induction and repair of radiation damace in Chlamydomonas. Curr. Top. Padiat. Pes. 5: 75-113. (NSA 23-38881).

Javies, D. R. and I. A. F. Thorburn. 1968. The effect of dose rate in relation to hypoxia, and the role of repair systems in the Ereen alga Chlarnyciononas: reinhardi. Tadiation Res. 35(2): 401-409.

Davies, J. R., F. D. Holt and D. G. Fapworth. 1969. the survival curves of haploid and diploid Chlamydomonas reinhardi exposed to radiations of different in Intern. J. Radiat. Biol. 15(1): 75-87. (Nif $23-24767)$.

Fahnrich, I. 1965. Inactivation of alcae cells with $x$-radiation. Radiation Bot. 5(6): 507-512. (In German) (NSA 20-8701). (Chlorelia. Chlamydomonas, Eurlena).

Gillham, ix. W. and R. F. Levine. 1962. Fure mutant clones induced by ultra-violet lient in the ereen alEa, Chlamydomonas reinhardi. Nature 194(4834): $1165-1166$. (NAA 16-20203). 
Cruber, 14. E. 1978. $X$-ray and proton-induced ultrastructural changes in dividinE Chlamydomonas reinhardi. Fadiation Res. 73(1): $137-159$.

Gruber, II. Z. and J. Z. Nachtwey. 1976. Cell cycle dependent $x$-ray-induced death in Chlamydomonas reinhardi. iadiation Ree. 66(2): 288-302.

Cruber, 3.2. and J. Z. Nachtwey. 1976. X-ray-induced division delay in Chlamydomonas reinhardi. ladiation Res. $66(2)$ : $303-303$.

jillova, J. 1966. Jecovery of $x$-ray induced damą"c in Chlamidomonas reinhardi. 3ull. soris lidric Inst. Aucl. Sci. 17(4)/A, uuppl.). (EnElish transl. $A: C-t r-6646 / 4 i)$. (isis 23-12236).

i:illova, J. 1967. Pailure of recovery from sub-lethal darage after ultraviolet irradiation in Chlamydomonas. Intern. j. Radiat. $2101.13(4): 3 E 3-3 \varepsilon 5$. Nidi $22-$ 3640/4).

Yillova, J. and $V$. Jra:il. 1967. The inhibitory effect of iodoace tamide on recovery from $=4 b-1$ ethal damare in Chlamycomonas reinhardi. Intern. J. kadiat. Jiol. 12(3): 201-20E. (Aini 22-40963). ( $B-$ raj).

Jiplics, $\dot{a}$... 1967. Immediate loss of flacella from Chlamydonoras reirhardi after uItraviolet irradiation. sajiation 3ot. $7(4): 347-343$. (NA 21-39540).

Iipkiss, $\therefore$. : 1971. Loss of flacella from Chlamydomonas reinhirdi after $x$-irradiation in the presence of iodcacetaride. :adiation Bot. 11(2): 171-173. (itis 25-47036).

Holt, -2.2 . 1969. The dosimetry of irradiations of Chlaroydomonas cells with high list radiations from a Var Je craaff accelerator. Fhys. l.ed. Biol. 14: 563-572. (NSA 24-4623).

Jacobrion, B. S. and T'. C. lee. 1967. Iiacromolecular synthesis and delayed mitotic death due to radiation and lrues in Chlamydomonas and Chlorella. Radiation Fes. $31(3)$ : $368-381$. (MEA $21-34824)$. 
Jacoscon, B. S. No date. Keversal of radiation damage in alrae. Final scientific report. Contract fit: $(40-1)-25 t 7$, Univ. of fexas, U. $\therefore$. AEC report CES465. 6 pp. (NSA 15-28989). (Chlamudomones reirharaii).

jacotson, 2. ... 1957. Evidence for recovery from $x-r a y$ tamace in Chlamidomonas. kajiation res. $7(4): 394-$ if 06 . (W:A $12-2672)$.

úacolson, ¿̇. $\therefore$ 1962. Kelationships between cell division and deatr. in $x$-irradiares chlamidomonas cultures. Cadiation ses. $17(1): 12-91$. (N.1 26$21980)$.

.acoicon, i. -. 1966. Wechanisme of lethal raviation dama'e and recovery in algal flagellater. 'inal rcientific report. Univ. of binnesota, $\mathrm{L} . \mathrm{S} . i_{2}=\mathrm{C}$ report CCC-1117-10. 37 pp. (iNSA 2l-13072).

(Chlemuclomonas reiniardi. Chlorelia elijpoiciea).

iacotson, E. C., L. J. Salmon and 1. L. Lansky. 1964. intimitotic effects of chloramphenicol and other inribitor's agents in Chlamwiomonas. Expt. Cell $\mathrm{ies}$. 36(1): 1-13. (NSA 19-7075). (X-irradiation).

Jokn, Y. I., J. C. i.cleod and t.. A. wirtht. 1967. Inhibition of chlloroplyll $A$ and $B$ synthesis: in Chlanvornonar reinhardi nutant strain y-2 to ionizin radiation. Radiation Bot. 7(2): $123-12 \mathrm{C}$. (Nsis 21-22280). (Electrons; $x$-rays).

Ladyin, V. $\mathrm{J}$, and ie. A. Burikov. 1972. Effects of ultraviolet radiation of an asynchronous culture an:1 on various sta: es of the ve: etative cellular c.clc of a cynchronous culture of Chlamydomonas reintari. Sadiobioloriya $12(5)$ : 723-729. TEn:lish trankl. A.ci-i, $r-7915)$ ). (iiSA 27-27829).

l.abyrin, V. G., G. A. Semenova and S. V. Tageyeva, 1972. jlastid ultrastructure of the white and "ellow mutants of Chlamidomonas reinhardi. 'Iri tologiya 14(12): 1455-1460. (In kiussian) (UisA 27-2002L). (X-irradiation).

Lawrence, C. H. 1965. Influence of non-lethal doses o: radiation on recombination in Chlamidomonas reintari. Nature 206 (4986): 789 799. (NiA 19-3184E). 
Lawrence, C. 2 is is6. The effect of dose duration in tr.e influence of irradiation on recombination in U.lar;domonas. iutat. nes. 2(6):487-493. (NoA 20-12(2)

lawrence, C. . 1967. Influence of nonlethal doses of radiation on allelic recomtination in Chlamvciomonas: reinharii. senetical Fes. 9: 123127 . (1ind 21223?3).

iavrence, c. $\therefore$. 1966. ffect of fractionated doses of raidation on recombination. lieredit? $23(1): 143-146$. (vis 22 49310). (Ckllamudomonas).

Iawrence, C. S. 196E. Radiation effects on genetic reconoination in Chlamidononas reinkardi. pp. 135lli:, In: iffecte of radiation on lieiotic ijstems. Interi. Atomic energy hency, Vienna, Austria, p:A tication S:I, TUB-I73. (NSA 24-21130).

Lawrence, C. A. 1970. Lose dependence for radiationinduced allelic recombination in crlamidomonas reinrardi. iutat. ines. 10: 557-566. (W.A 25-2ti22).

Lawrence, $C$. $A$ and $b . j$. liolt. 1970. iffect of gamina radiation and alpha particles on ene recombination in chlam,domonas reinharai. i.utat. kes. 10: 545.555 . $($. 2525123$)$.

. iaciokova, s., S. rodstavkova and T. Thi Hoa. 1973. injiolo ical responce of Chlamidomonas reinhardi uane. cells to treatment with $\mathrm{N}$-nitroso-N-methylurea and ultraviolet radiation. Biologia (Bratislava) $2 €(6): 451-462$. (In Slovak) (NiA 30-24229).

.rom, N. 1953. :ome experiences from mutation experimentr in Chlamiomonas; Hereditas $39(4): 317-324$. $(x-$ and UV-irradiation).

fodctavkova, s., E. L..iadokova and H. I'hi Hoa. 1973. sutarenic effect of $N$-nitroso-N-methylurea applied alone and combined wi th ultraviolet irradiation on Chlarndomonas reinhariij Dang. cells. Biolofia (Braticlava) $26(6): 469.476$. (In Slovak) (Nisa 30$24228\}$. 
Josner, H. B. and A. H. Sparrow. 1964. Surviva? of Chlorella and Chlamydomonas after acute and chronic gamma radiation. Radiation bot. 4(3): 253-257. (1ish 19-5685).

Fosen, H. and $\%$. T. Ebersold. 1972. Recombination in relation to ultraviolet sensitivity in Chlamydomonas reinhardi. Genetics $71(2): 247-253$. (NSA 26-41112).

Eyznar, I. and V. Drasil. 1967. Fhotoreactivation in Chlamydomonas reinhardi Dangeard. Folia dicrobiol., Praha 12: $524-528$.

Whevchenko, V. A., V. P. Vizein, A. Ya. Alekseyenok, I. i. liogan, D. R. Pyatyshey and N. P. Foratykh. 1969. Investigation of mutarenesis induced by acute and chronic ionizing irradiation in populations of Chlorella and Chlamidomonas. Genetika 5(9):61-73. (In iuseian) (iISA 24-675).

Tommasino, I., G. F. Whitmore and G. Silini. 1979, A new approach to the analysis of survival data, haciation Res. 77(1), 128-148. (Includes Chlamydomonac).

Lnderbrink, A. G., A. H. Sparrow and V. Pond. $196 C$. Chromosomes and cellular sensitivity - II. lie of interrelationehips anong chromosone volume, nucleo. tide content and $D_{0}$ of 120 divere $\epsilon_{\text {of }}$ onjerms in predictin $\tilde{i}$ radiosensitivity. Radiation Bot. $8(3)$ : 205-238. (Includes Chlamydomonas reinhardi. Faria pipiens, vurlena Eracilis, Amphiuma. NecturusT.

Wetherell, D. $P$. and R. W. krauss. 1957. X-rav-induced mutations in Chlamydomonas engametos. am. j. jotany $4 i$ (?): 609.619 .

(chlorella)

Anikeyeva, I, D. and Ye. V, joskvitin. I971, Kesults of combined exposure of Chlorella to vibration and Eamma irradiation. liosmich. Biol. l.ed. 5(3): 85-87. (English transl. JFRi-53801). (NiA 25-49315; 2552254 ).

Anikeyeva, I. 2., Z. i. Vaulina and V. A. Sheychenko. 1964. Influence of UV ravs on Chlorella. Kadiobiologiya 4(6), 883-893. (Englisin trans1. AEC-tr-6409). (NSA 19-17615). 
Anikeyeva, I. D., Ye, $\because$. Yaulina and V. A. Shevchenko. 1966. Lffect of $L V$ rays on various states of the cell cycle of chlorella. pp. 1t-2l. In: iffect of Ionizine vaciation on Heredity. (N. f, Jubinin, ed.). l.oscow, Fubl. House hcad. Eci. LusR. (In kussian) (1). $22-21631)$.

ipasheva, i. i... and $i$. V. Gusareva. 19?3. ihodification of the railiosencitivity of chlorella within the mitotic cycle. hadiobiolo iya 13(5): 761-765. (inrlish transl. inc-tr-750?). (Avi 29*26990).

Apasheva, I. H. and Z. V. Gusareva. 1974. Radiosensitiz ins effect of $\mathrm{N}$-ethymaleimide on cells of three strains of chlorella vilaris, differing in radiosensitivity. iafiobiolo iya li(2): 267-290. (an lish tranel. AcC$\operatorname{tr}-7571)$. (WSA 30-32397).

spacheva, L. l... j. V. usareva, A. V. liulinich and V. i. Shevchenko. 1972. Investiration of tre role of Hiol: in the determination of the radiosensitivity of various straine of Chlorclla vulgaris Beijer. fiadiobiolo iya 12(C): $904-906$. TEn!lish tranel. :UCtr-?

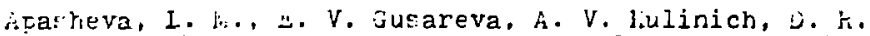
F.:atyshev and $V$. f. Thevchenko. 1973. Investization of tele role of thiols in the modification of the radiosensitivity of chlorella jurin the cell cjcle. Eailobiolo ije 13(I): $102-105$. (En:lich tranrl. ALCir -7430$)$. (N.A 28-1E442).

Arnaud, in. 1966. Irradiations continues aux rayons $x$ de cultures de chlorelies. Thesis, Grenoble Univ., France. (U. $\therefore$. ALC document number NF-17125).

barber, D. A., G. J. Neary and R. S. Kussell. 195?. Salliosensitivity of salt in plants. Wature 180(4585): 556-557. (Chlorella pyrenoidosa).

Eendix, S. and M. B. Allen. 1962, Ultraviolet induced mutants of Chlorella pyrenoidosa. Arch. Wikrobiol. 41. 115-141. (NSA 20-8648).

Eonham, k. and K. F. Ialumbo. 1951. iffects of x-rays on enails, crurtacea, and algae. Growth 15(3): 15518E. (Gadix japonica, "hais lamellosa, amphirod, Artemia salina, Chlorel la, Ankistrodesmus, Chroococcus, synechococcue). 
Brandt, A. B. and V. A. Krylov. 19?1. Stimulation of the growth of Chlorella pyrenoidosa by continuous irradiation with ultraviolet of low intensity. (Biofizika 16(4). (Enelish transl. pp. 760-763). (NEA 26-36347).

Cabela, E. and H. Altmann. 1971. Determination of irradiation effects on the thymidine kinase activities within a cell-cyclic of synchronously frowing Chiorella. A. Naturforsch, 26b: 149-151. (In German) (NiA 25-37897).

Cabela, E., E. Wawra and H. Altmann. 1971. Repair of strand breaks in Chlorella-DNA caused by gamma irradiation. Biophysik 7,200-204. (In German) (Nit) $25-35257)$.

Cabela, Ė., $\bar{E}$. Wawra and H. Altmann. 1972. Repair of radiation-induced DNA strand scissions in Chlorella during the cell cycle. Biopkysik 8(2): se-95. (NEA 26-36327).

Chandorkar, K. R., R. B. Szachrajuk and G. H. Clark. 1976. Effect of extremely low radiation dosages on synchronized cultures of Chlorella pyrenoidosa. Health Fhys. 35(5): 494-498.

Clades, H. 1954. Das Auftreten von $\mathrm{Zwischenprodukten}$ der Carotinoidsynthese vei ronteninduzierten Jiutanten und der Nachweis eines lichtfaktors bei der Carotinoidsynthese von Chlorella vulEaris. Coner. Intern. Bot. Fap. et Commun. Deuxieme ser 8 (sect. $11 / 12$ ): $78-79$.

Dubinin, N. P., V. A. Shevchenko, A. V. Rubanovich, L. K. Vekshina and I. S. Sakovich. 1975. Iffect of ionizinf radiations with different LET on survival and mutation in Chlorella. pp. 181-186. In I Ife Sciences and Space Research. XIIT. AkademieVerlag G. m. b. H., Berlin. (NSA 33-29571).

Durymanova. S. A. 1964. Chemical protection of Chlorella arrainst UV-radiation. Radiobiologiya $4(6), \frac{9}{923-924 .}$ (English transl. AEC-tr-6409). (NEA 19-17688).

Fahnrich, P. 1965. Inactivation of algae cells with $x$-radiation. Radiation Bot, 5(6): 507-512. (In German) (NSA 20-8701). (Chlorella, Chlamydomonas. Euflena). 
Fetter, F. and II. AItmann. 1968. Investifations on radioinduced chan:es in nuclei and metabolism of Chlorella pyrenoidosa. Bodenkulter 19:320-335. (In verman) (NA 23-24530).

Forctber:, $\dot{A}$. 1933. The time factor in the biological action of x-irradiation. II. Studies on alfae and Drosophila pupae. Acta Radiol, $14(4): 399-40$ ?. (In ierman) (scenedesmus. Chlorella, i,esotaenium).

ilet, i. 2965. Remarks on the extrapolation numbers from survival curves of various populations of Chlorella pyrenoidosa Chick after $\mathrm{x}$-irradiation. Compt. Fend. 261: 5686-56ce. (In French) (NSA $20-16246)$.

Gilet, R. 1971. Survival curves and cell restoration of ramma-irradiated Chlorella. France Commicsariat a l'Ener'ie Atomique, Centre d'itudes Nucleaires, Grenoble report CEA-H-4139. $112 \mathrm{pp}$. (In French) $(i+i)$ 25-47031).

illet, $i$. 1972. Iotentially lethal damare after gamma irradiation in Chlorella cells (green unicellular alfa). Stud. Biophys. 30(1): 37-44. (Nis 27-5457).

Gilet, $P$. and $J$. Terrier. 1969. Effect of the restoration processes make it possible to distinguish acute and subacute irradiations in Chlorella. Compt. Rend. D269: 383-385. (In French) (NSA 24-6142).

Gilet, R. and J. Terrier. 1970. Interpretation of the gamma ray survival curves of Chlorella. Bull. Inform. Sci. Tech. (Paris) (145): 67-72. (In French) (NSA 24-34766).

Gilet, R. and S. Santier. 1973. Analysis of clonal survival curves obtained on $\gamma$-irradiated Chlorella cells at several dose rates. Biophysik. 9(4): $335-$ 348. (In French) (NSA 28-30055).

Gilet, K. and 3 . Santier. 1979. Repair of potentially lethal camage in a Eama-irradiated autotrophic microorganism. Intern. J. Radiat. Biol. 35(5), 477480. (Chlorella pvrenoiciosa). 
Gilet, R., S. Santier and A. Villeroux. 1963, Comparative effect of $x$-rays of medium energy and of soft $x$-rays on the survival rate of Chlorella pyrenoidosa. Compt. Rend. 257(13): 1985-1988. (In French) (NSA 18-1393).

Gileva, Ye. A.. N. A. Timofeyeva and N. V. TimofeyevResovskiy. 1965. Influence of $60^{\circ}$ o gamma irradiation on the growth of Chlorella cultures. Radiobiologiya 5(5): 732-?34. TEnglish tratsis. AEC-tr6602 ). (NSA 20-53E9).

Hampl, W.. H. Altmann and R. Biebl. 197l. Variation in and effects of repair capacity of Chlorella cells at different stages of the cell cycle. Radiation Bot. 11(3): 201-207. (In German) (NSA 25-47050).

Jacobson, B. S, 1966. Wechanisms of lethal radiation damage and recovery in algal flagellates. Final scientific report. Univ, of hinnesota, U. S. AEC report C00-1117-10. 37 pp. (NSA 21-13072).

(Chlamydomonas reinhardi. Chlorella eliipsoidea).

Jacobson, B. S. and T. C. Lee. 196?. Macromolecular synthesis and delayed mitotic death due to radiation and drugs in Chlamydomonas and Chlorella. Radiation Res. $31(3)$ : 368-381. (NSA 21-34824).

Kamchatova, I. E., I. A. Zakharov, V. G. Korolev, I. Mi. Gracheva and N. Yu. Zheleznyakova. 1975. Study of the lethal action of ionizing radiation on Chlorella cells with various contents of intracellular cysteine. Radiobiologiya 15(2): 218-221. (English transl. ERDA-tr-51). (NSA 33-5699).

Kamshilov, M. M. 1963. The influence of ultraviolet light on microbiocoenoses of marine protozoa. Doklady Akad. Nauk SSSR (Biol. Sci.) 150(6): 1363-1365. (English transl. pp. 671-673). (Electonema notatum, diatoms, flagellates, amoebae, ciliates, bacteria, yeast-like cells, (hlorella).

Karpov, V. L. and V. F. Fillipov. 1965. Effects of ${ }^{14} \mathrm{C}$ beta particles in chlorella growine in a medium containing ${ }^{14} \mathrm{C}$-carbonates. Radiobiologiya 5(4), $580-$ 583. (English transl. AEC-tr-6601). (NSA 19-42253). 
Khropova, V. I., K. V. Kvitko and I. A, Zakharov. 1964. Comparative study of mutagenic effects of various types of radiation and ethylenimine on chlorella algae. Issled. Genet. 2: 69-76. (In Russian) (NSA 22-51496).

Knosy, H, U. 1972. Biological effectiveness of the primary reactions of thermal neutrons. 1. Damage rates and effectiveness of the capture reactions of thermal neutrons in Chlorella pvrenoidosa. Radiation Bot. 12(4): 261-269. (In German) (NSA 2659015).

Kroop. H. U. and $H$. Paschke. 1973. RBE of the $10_{B}(n, \alpha)$ Li capture reaction of thermal neutrons inside the ereen alga Chlorella pvrenoidosa. Kernforschungsanlage, Juelich, Germany. vp. (NSA 29-15875).

Kneop, H. U. and M. Paschke. 1974. RBE of the $10_{B(n, \alpha) 7}$ Ii capture reaction of thermal neutrons inside the green alga Chlorella pyrenoidosa. pp. 215-219. In. Biolocical Effects of Neutron Irradiation. Intern. Atomic enerey Agency, Vienra, Austria, publication STI/PUB-352. (NSA 30-3528).

Kossler, F, 1964. Breathing depression after chronic $\gamma$-irradiation and photoreactivation in Chlorella. iNaturwissenschaften 51(12): 289. (In German) (NSA 18-31193).

Kossler, F. 1964. Respiration and photosynthesis of Chlorelia during gamma irradiation. Thesis, HumboldtUniversitat, Berlin. $76 \mathrm{pp}$. (In German) (NSA 1929992).

Kossler, F. 1965. Respiration and photosynthesis of Chlorella under chronic $\gamma$-irradiation. Radiation Bot. 5(2): 115-123. (In German) (NEA 19-24333).

Kunz, W. F: 1972. Response of the alga Chlorella sorokiniana to $60 \mathrm{Co}$ gamma radiation. Nature 236 (5343): $178-179$. (NSA 26-33656).

licleod, G. C. 1958. Delayed light action spectra of several algae in vicible and ultraviolet light. J. Gen. Fhysiol. 42(2): 243-250. (Anacystis, Forphyridium, Chlorella, Dunaliella, Ronochrysis, Phaeodactylum. coscinodiscus). 
Mcleod, G. C, and J. McLachlan. 1959. Sensitivity of several algae to ultraviolet radiation of $253.7 \mathrm{m \mu}$. Physiol. Flant. 12(2): 306-309. (Chlorella, Scenedesmus, Ankistrodesmus, Botryococcus, Flatymonas, Dunalielia, Phaeodactylum, Sheletonema).

Viorton, S. D. and P. H. Derse. 1968. Use of gamma radiation to control algae. Environ. Sci. Technol. 2(11): 1041-1043. (NSA 23-5057). (Anabaena, Aphanizomenon, iilicrocystis, Chlorella. Gomphonema).

Nishina, J., H. Nakamura and H. Nakayama. 1940. Effect of neutrons on photosynthesis. Bull. Inst. Phys. Chem. Res. 19(10): 1343-1347. (In Japanese)

(Chlorella. Scenedesmus).

Nokes, M. A. and M. Simic. 1975. X-ray sensitivity of photosynthesis and reproductive systems in Chlorella. Fhotochem. Fhotobiol. 21(4): 265-268. (NSA 32-28206).

Ozenda, F. 1965. Some aspects of the radiobiology of chlorophyliic microorganisms. pp. 341-366. In: Travaux Dedies a Lucien Plantefol. liasson et Cie, Paris. (In French) (NSA 21-26 48 ). (Scenedesmus crassus. Chlorella vulearis. Chlorella pvrenoidosa).

Ozenda, F. 1970. Chlorella, a radiobiological material. Bull. Inform. Sci. Tech. (Paris) (145):49-52. (In French) (NSA 24-34757).

$\mathrm{O}_{201}$, A. A. 1973. Induced mutagenesis in strains of Chiorella valearis differing. in their radiosensitivity. Genetika 9(4): 39-48. (In Russian) (NSA 28-10994).

Ozol, A, and $N$. Yu. Zheleznyakova. 1971. UV-sensitive mutants of Chlorella vulgaris and their capacity to photoreactivation. Genetika 7(8): 143-149. (In Russian) (NSA 25-55172).

Faschinger, H, and T. Vanicek, 1974. Effects of gamma irradiation on the two mechanisms of $R b(K)$ uptake by Chlorella. Radiation Bot. 14(4), 301-307. (NSA 321059).

Fluchennik, H. 1965. Wutation process of Chlorella induced by incorporation of radioactive carbon dioxide. Genetika (5), 19-25. (In Russian) (NSA 20-22674). 
Forter, J. W. and h. S. Watson. 1954. Gross effects of growth-inhibiting levels of tritium oxide on Chlorella pyrenoidosa. Am. J. Bot. $41(7): 550-555$. (N5A 81498).

Forter, J. N. and H. J. Knauss. 1954. Inhibition of growth of Chlorella pyrenoidosa by beta-emitting. radioisotopes. Flant Fhysiol. 29(1): 60-63. (NSA $8-975)$.

Forter, J. W. and H. J. knauss. 1954, the effect of tritium oxide on some synthetic processes of Chlurella pyrenoidosa. Radiation Ree. 1(3): 253-261. TNSA 82086).

Fosner, H. B. 1965. Effects of Eamma irradiation on erowth, colony-forming ability and some cellular constituents of Chlorella pyrenoidosa. Radiation Bot. 5(2): 129-141. (N5A 19-24334).

Fosner, H. B. and A. F. uparrow. 1964. Survival of Chlorella and Chlamydomonas after acute and chronic Eamma radiation. Radiation Bot. 4(3): 253-257. (NSA 19-5685).

Rodicheva, E. K., I. I. Gitel'zon and I. A. Terskov. 1966. Action of ultraviolet radiation on the Chlorella under conditions of continuous, intensive cultivation. Izv. Libirsk. Otd. Akad. Nauk iSR (12) (Biol. ived.) (3): 33-37. (In Russian) (NSA 21-28676).

Rogatykh, N. F. 1971. Radiostimulation of the growth of Chlorella at various staees of the cellular cycle. Radiobiologiya 11(I): 92-95. (English transl. AECtr-7233). (NijA 25-44967).

Poux, J.C. 1966. Radiosensitivity of Chlorella after medium energy accelerated electron irradiation. Centre d'Etudes Nucleaires, Commissariat a l'Energie Atomique, Grenoble, France, report CEA-R-2984. $72 \mathrm{pp}$. (NSA 20-45353).

Roux, J. C. 1970. Radiosensitivity of Chlorella to alpha particles. Bull. Inform. Sci. Tech. (Paris) (145): 61-66. (In Erench) (NSSA 24-34758). 
Sakovich. I. S. 1971. Characteristics of a Chlorella culture in the transitional period of increase in optical density after irradiation. Radiobiologiya II (4): 633-635. (English trans1. AEC-tr-7304). (NSA 26-636340).

Sakovich, I. S. 1973. Influence of fractional irradiation on the survival and mutability of Chlorella. Radiobiologiya 13(5): 758-761. (English transl. AEC-tr-7507). (NSA 29-26989).

Sakovich, I. S. and I. K. Vekshina. 1969. Survival of Chlorella upon continuous cultivation after a single Eamina-irradiation. Kosm. Biol. Med. 3: 24-27. (In Russian) (NSA 24-23399).

Sakovich, I. S. and L. K. Vekshina. 1970. Survival of Chlorella irradiated with MeV protons. Kosmich. Biol. Med. 4(3), 86-87. (In R!ssian) (NAA 2552257).

Sakovich, I. S. and O. F. Ovchinnikova. 1971. Variation of the survival of Chlorella as a function of the density of the irradiated suspension. Radiobiologiya II(3): 472-473. (English transl. AEC-tr-7303). (NSA 26-33622).

Sakovich, I. S, and I. K. Vekshina, 1975. Dependence of the viability and mutability of Chlorelia on postradiation storage conditions. kosm. Biol. kied. 9(2): 84-85. (English transl. JPRS-64929). (NSA 32-14471).

Sakovich, I. S., I. Y. Smimov, V. A. Sakovich and I. K. Vekshina. 1967. A mathematical model for Chloreliacultivation parameters under conditions of ionizing irradiation. Kosm. Biol. Hed. $1: 44-47$. (In Russian) (NSA 22-52058).

Schwarze, F. 1967. Nulticellular Chlorella mutants. Flora (Jena) Al58, 545-548. (In German) (NSA 2322268). (UV irradiation).

Shabanova, E. A. 1972. Influence of chronic eamma irradiation on Chlorella. Radiobiologiya 12(I): 140-144. (English trans1. AEC-tr-7316). (NSA 26-50830). 
Shevchenko, V. A, 1965. X-ray influence on survival and mutagenic process in Chlorella. Radiobiologiya 5(2): 253-259. (English transl. AEC-tr-6599). (NSA 19-28080).

Shevchenko, v. A. 2966. Analysis of the nature of radiation damaee to Chlorella cells. pp. 8-15. In: Effect of Ionizing Radiation on Heredity. (N. P. Dubinin, ed.). Moscow, Publ. House Acad. Sci. UTSR. (In Russian) (NiA 22-21474).

Shevchenko, V. A. 1967. Natural and induced mutation in Chlorella. Uspekhi jovrem. Genet. (1): 246-278. (In Russian) (NNA 23-26754).

Shevchenko. V. A. 1970. Genetic adaptation of Chlorella populations to chronic effect of ionizing radiation. Cenetika 6(8): 64-73. (In Fussian) (NSA 24-50843).

Shevchenko, V. A., I. S. Sakovich, L. K. Meshcheryakova and M. G. Petrovnin. 1967. The vital activity of Chlorella under spaceflight conditions. Kosm. Biol. Ned, 1: 25-28. (NSA 22-17057).

Shevchenko, V. A., A. Ya, Alekseenok, B. S. Prister and G.G. Ryabov. 1973. iffect of fission products of $235 \mathrm{U}$ on the mutation process in Chlorella cultures. pp. 102-108. In: Radioecology of viater Organisms. III. The Effect of Ionizine Radiation on water Orranisms. (G. F. Andrushaitis, ed.). Riga, Izdatel'stvo zinatne. (English transi. AEC-tr-7592). (NSA $30-24377$; 31-11685).

Sherchenko, V. A., V. P. Vizgin, A. Ya. Alekseyenok, I. G. Kogan, D. R. Fyatyshev and N. P. Rogatykh. 1969. Investigation of mutagenesis induced by acute and chronic ionizing irradiation in populations of Chlorella and Chlamydomonas. Genetika 5(9), 61-73. (In Russian) (NSA 24-675).

Shurashkevich, 0. N. 1966. Effect of ionizing radiation on the metabolic processes of Chlorella. Ukr. Botan. 2h. 23: 79-81. (In Russian) (NSA 21-45847).

Solomon, M. J. and F. A. Crane. 1968. Isolation and characterization of some UV-induced mutants of Chlorella vulgaris Frings. J. Fharm. Sci. 57: 2038-2044. (NSA $23-9921$ ). 
Tugarinov, V. V. and V. V. Kuznetsov. 1966. Combined effects of $x$-rays and $s$ treptomycin on the mutability of Chlorella aleae. Tr. losk. Obshch. Ispyt. Frirody (3iol.) 22, 163-169. (In Russian) (NiA 2251511).

Tugarinov, $v$. $V$, and $V, V$. Kuznetsov, 1966. Combined effect of $x$-rays and streptomycin on the mutability of Chlorella. Genetika (2): 57-63. (In Russian) (NSA 20-32993).

Ujihara, A., S. Mori and S. Hori. 1965. Genetic studies on radio-resistant strain of Chlorella ellipsoidea. I. Radiosensitivity and a radio-resistant strain induced by repeated Eamma-irradiation in Chlorella ellipsoidea. Ann. Rep. Radiat. Center Osaka Prefect. $6: 90-92$ (NSA 20-38605).

Vekshina, L. K., I. S. Sakovich and V. A. Shevchenko. 1974. Influence of densely ionizing radiation on Chlorella. Radiobiologiya 14(3): 386-389. (Enelist. transl. A $\bar{E} C-t r-7596$ ). (NSA $31-16758$ ).

Vekshina, L. K., I. G. Kogan, N. F. Rogatykh, I. S. Sakovich and V. A. Shevchenko. 1969. Repair of visible mutations and lethal injuries in Chlorella. Biol. Nauki (10): 105-107. (In Russian) (NSA 2427576).

Vekshina, I. K., I. G. KoEan, E. I. Kudryashov, D. F. Pyatyshev, I. S. Sakovich and V. A. Shevchenko. 1969. Effect of alpha-irradiation on Chlorella survival and mutation. Kosm. Biol. lied. 3(5): 3438. (In Russian) (NSA 24-6025).

Vekshina, I. K., I. G. Kogan, Ye. I. Kudryashov, A. li. Harcennyi, D. R. Pyatyshev, I. S. Sakovich and V. A. Shevchenko. 1970. Relative biological effectiveness of multicharged ions during single irradiation of Chlorella. Kosm. Biol. Hed. 4(5): 39-42. (English trans1. JPRS-52121). (NSA 25-16375; 25-21964).

Zakharov, I. A. and V. V. Tuearinov. 1964, Radiosensitivity of the unicellular alga chlorella vulgaris. Radiobiologiya 4(I): 92-95. (Enelish transl. $A E^{\prime}$ tr-6404). (NSA 18-17581). 
(Desmid)

Forssberg, A. 1934. The effect of roentgen radiation on the development of liesotaenium caldariorum. Acta Radiol. 15(6): 803-807. (In German).

Godward, Ri. B. E. 1960. Resistance of algae to radiation. Nature 185(4714): 706. (NSA 14-9349). (Spirogyra. zygnema, liougeotia, Cosmarium, Euglena, eudorina. Chaetomorpha, Prorocentrum).

Hart, R. W. 1971. UV- and $x$-ray response of the desmid, Iicrasterias decomdentata. Thesis, Univ. of Illinois, Urbasa. (Uni v. l.ifcrofilms order No. 72-12,195). (NEA 26-31274).

Kallio, F. and H. Heikkilae, 1969. UV-induced facies change in licrasterias torreyi. Osterr. Bot. Z. 116: 226-243. (NSA 23-45962).

Harcenko, E. 1965. Restoration of irradiated algae after a period of darkness. Nature 207(4996): 542-543. (NSA 19-38410). (Micrasterias truncata).

liarcenko, E. 1966. The effects of gamma rays on algae (Desmidiaceen). Frotoplasma 62: 156-183. (In German) (INSA 2l-36760).

Oedogonium)

Banerjee, 2 . N. and R. J. Horsley. 1973. Ëffects of metabolic inhibitors on Eiant cell formation in Oedogonium Cardiacum: Radiation Res. 54(1): 121-129. (NSA 285956).

Horsley, R. J. and L. A. Fucikovsky. 1962, Radiosensitivity of Dedogonium zoospores and short multiplecell chains at increasing ages (abstr.). p. 226. In: Second Intern. Congress Radiation Research. Silver End Documentary Fublications, Ltd., London.

Horsley, R. J. and I. A. Fucikovsky. 1963. Changes in dose-sirvival curves durine the division cycle of Oedogonium cardiacum (abstr.). Radiation Res. 19(1). 219. 
Horsley, R. J. and I. A. Fucikovsky. 1963. Further growth and radiation studies with filamentous Ereen al fae. Intern. J. Radiat. Biol. 4(4):409-428. (Oedogonium cardiacum).

Horsley, R. J. and L. A. Fucikovsky, 1963. Variation in radiosensitivity durinf the cell-cycle of Oedogonium cardiacum. Intern. J. Radiation Biol. $6 ( 5 ) \longdiv { 4 1 7 - 4 2 9 } .$ (NSA $17-38795)$.

Horsley, R. J. and C. M. Fujara. 1969. Study of the inflexion in $x$-radiation survival curves for synchronized cell populations of the Ereen alga (Oedoronium cardiacum). Radiation Res. $40(2): 440-449$. (NSA 249971).

Horsley, R. J. and A. Laszlo. 197l. Unexpected additional recovery following a first $x$-ray dose to a sychronous cell culture. Intern. J. Radiat. Biol. 20(6): 593596. (Oedogonium cardiacum).

Horsley, R. J., S. N. Banerjee and li. Banerjee. 1967. Analysis of lethal response of gedogonium cardiacum irradiated at different cell staEes. Radiation Bot. $7(6): 465-476$.

Horsley, R. J., I. A. Fucikovsky and S. N. Banerjee. 196?. Studies on radiosensitivity during the cell cycle in Oedoeonium cardiacum. Radiation Bot. $7(3)$ : 241-246.

Howard, A. 1968. The oxyenen requirement for recovery in split-dose experiments with oedogonium. Intern. J. radiat. Jiol. $34(4) \cdot 341-350$. (NSA 23-26957) (x-ray).

Howard. A. 1970. Dose-modifying factors and inhibitors of repair. pp. 305-308. In: Radiation Frotection and Sensitization. (H. Moroson, ed.). Barnes and Noble. NY. (NSA 25-4574). (Dedogonium cardiacum).

Howard, A. 1970. Role of oxygen in the repair process. pp. 70-81. In: Conference on Time and Dose Relationships in Radiation Biology as Applied to Radiotherapy. Brookhaven National Lab. U.S. AEC report BNI-50203. (CONF-690915). (NSA 25-11304). 
Howard, A. 1973. Dependence of radiation sensitivity on oxygen tension in Oedogonium. I. Extra- and intra-cellular oxygen. Radiation Bot. 13(5) : 293296. (NSA 29-18586).

Howard, A. and R. J. Horsley. 1960. Filamentous green algae for radiobiological study. Intern. J. Radiat. Biol. 2(3): 319-330. (Oedogonium cardiacum).

Howard. A., C. W. Gilbert and D. Greene. 1974, Dependence of radiation sensitivity on oxygen tension in Oedogonium. II. Effect of temperature and LET. Radiation Bot. 14(2): 101-10?. (NSA 30-27027).

Howard, A., C.W. Gilbert and D. Greene. 1974, Dependence of radiation sensitivity on oxygen tension in Oedogonium. III. Applicability of the HowardFlanders-Alper formula for $14 \mathrm{MeV}$ neutron irradiation. Radiation Bot. 14(4): 351-353. (NSA 32-1060).

Farker, K. E. and R. J. Horsley. 1972. Ultraviolet radiosensitivity of Dedoronium cardiacum cells at various stages of the cell cycle. Radiation Bot. $12(4): 239-248$. (NSA 26-59013).

Fujara, C. M., R. J. Horsley and S. N. Banerjee. 1970. Radiation-induced division and mitotic delay studies in ereen algae (Oedogonium cardiacum). Radiation Res. 44(2): 413-420. (NSA $25-8644)$.

(Scenedesmus)

Forssberg, A. 1933. The time factor in the biological action of $x$-irradiation. II. Studies on algae and Drosophila pupae. Acta Radiol. 14(4): 399-407. (In (jerman) (scenedesmus, chlorelia, (hesotaenium).

Gilet, $R$. and P. Ozenda. 1960. Action of $x$-rays on the Erowth of cultures of a one-celled chlorophyll oreanism: Scenedesmus crassus Chod. (chlorophyll algae). Compt. Rend. 250, 1552-1554. (English transl. AECtr-4601). (NSA 14-12467; 15-19160). 
Gilet, R. and P. Ozenda. 1961. Analysis of the effect of $x$-rays on the multiplication of a unicellular chlorophyll organism: Scenesdesmus crassus Chod. Compt. Rend. 252(24): 3867-3869. (In French) (NSA 15-25869).

iricleod, G. C. and J. licLachlan. 1959. Sensitivity of several algae to ultraviolet radiation of $253.7 \mathrm{~m} \mu$. Physiol. Plant. 12(2): 306-309. (Chlorella, Scenedesmus, Ankistrodesmus, Botryococcus, Flatymonas, Dunaliella, Fhaeodactylum, Skeletonema).

Nishina, J., H. Nakamura and H. Nakayama. 1940. Effect of neutrons on photosynthesis. Bull. Inst. Fhys. Chem. Res. 19(10): 1343-1347. (In Japanese) (Chlorella, Scenedesmus).

Ozenda, P. 1965. Some aspects of the radiobiology of chlorophyliic microorganisms. pp. 341-366. In: Travaux Dedies a Lucien Plantefol. Iiasson et Cie, faris. (In French) (NSA 2l-20438). (Scenedesmus crassus. Chlorella vulgaris, Chlorelia pyrenoldosa).

(Others)

Berger, 3. 1967. The ability of unicellular synchronized volvocales to divide after $\mathrm{x}$-irradiation. Intern. J. Radiat. Biol. 12(5): 477-486. (In German) (Haematococcus pluvialis. Chlamydomonas spp.).

Bonham, K. and R. F. Falumbo. 1951, Effects of $x$-rays on snails, crustacea, and algae. Growth 15(3): 155188. (Radix japonica, Thais lamellosa, amphipod, Artemia salina, Chlorelia, Ankistrodesmus, Chroococcus, Synechococcus

Ducoff, H. S. 1965. Recovery from radiation-induced division block in protists. Illinois Univ., U. S. AEC final report for contract AT(11-1)-878, c00-87815. $17 \mathrm{pp}$. (NSA 19-21856). (Brachiomonas submarina, Chilomonas paramecium).

Ducoff, H. S., B. D. Butler and E. J. Geffon. 1964. $X$-ray survival studies on the alga Brachiomonas submarina Bohlin. Radiation Res. $23(3): 446-453$. 
Ducoff, H. S., B. D. Butler and E. J. Geffon. 1965. The effect of radiations on replication in Brachiomonas submarina Bohlin. Radiation Res. 24(4):563571. (NSA 19-24340).

Ehrhardt, J.F. 1973. Effect of $\boldsymbol{\gamma}$-irradiation on the respiration of unicellular algae. Compt. Rend. Soc. Bio1. 167(11): 1529-1531. (In French) (NSA 3018879). (Phormidium fovelolarum, Dunaliella salina).

Godward, F. B. E. 1954. Irradiation of spirogyra chromocomes. Heredity 8(2): 293.

Godward, K. B. E. 1960. Resistance of algae to radiation. Nature 185(4714): 706. (NSA 14-9349). (Spiropyra, Zygnema, Mougeotia, Cosmarium, Euglena, Eudorina, Chaetomorpha, Prorocentrum).

Halberstaedter, L, and A, Luntz, 1929. Die Nirkune der Radiumstrahlen auf Eudorina elegans. Arch. Protistenk. 68: $177-186$.

Halberstaedter, I. and I. Back. 1942. The effect of $\mathrm{x}$-rays on single colonies of Fandorina. Erit. J. Siadiol. 15(172): 124-128.

hiarrison, F. I. and J. J. Koranda. 1973. Tritiation of aquatic animals in an experimental freshwater pool. pp. 425-434. In: Radionuclides in Ecosystems. (i. J. Nelson, ed.). U. S. AEC report CONF-710501-Fl. (N5A 26-9484). (Clams, crayfish, goldfish, cattails, Fithophora, plankton).

Haupt, W., F. Mugele and D. Wuller. 1959. Auslosung der Chloroplastendrehung bei Hougeotia durch UV-Strahlung. Naturwissenschaften 46 (12): 409 .

Holweck, F, and A. Lacassagne. 1931. Actions des rayon $X$ sur Folytoma uvella. Determination des "cibles" correspondent aux principales lesions observees. Compt. Rend. Soc. Biol. 107: 812-814.

Jeschke, W. D., H, Gimmler and W. Simonis. 1967. Incorporation of $32 \mathrm{p}$ and $14 \mathrm{C}$ into photosynthetic products of ankistrodesmus braunii as affected by $x$-rays. tlant thysiol. 42(3): $380-386$. (INSA 21-24682). 
Kemp, C. L. 1972. Iiquid-holding and recovery from UV-induced damage in Eudorina elegans. Arch. Viikrobiol. 86: 255-264. (NSA 27-5452).

i.cleod, C. C. 1958. Delayed light action epectra of several aleae $\dot{i}_{1}$ visible and ultraviolet light. J. Cien. Physiol. 42(2): 243-250. (Anacystis, Forphyridium, Chlorelli, Dunaliella, llonochrysis, Phaeodactylum, coscinodiscus).

HcLeod, G. C. and J. licLachlan. 1959. Uensitivity of several algae to uitraviolet radiation of $253.7 \mathrm{m \mu}$. Physiol. Plant. 12(2): 306-309. (Chlorella, Scenedesmus, Ankistrodesmus, Botryococcus, Flatymonas, Dunaliella, Phaeodactylum, Skeletonema).

liantai, K. E. and N. I. Bishop. 1967. Studies on the effects of ultraviolet irradiation on photosynthes is and on the $520 \mathrm{~mm}$ lieht-dark difference spectra in green alras and isolated chloroplasts. Biochim. Biophys. licta 13i: 350-356. (NSA 21-30781).

i.iishra, N. C. and E. F. H. Threlkeld. 1968. Genetic studies in Eudorina. Genetical Res. 1l: 2l-3l. (NSA 22-38.241). (Irradiation).

liorton, S. D. and P. H. Derse. 1968. Use of gamma radiation to control algae. Environ. Sci. Technol. 2(11): 1041-1043. (Nis 23-5057). (Anabaena, Aphanizomenon. liirrocystis, Chlorelia, Griuphonema).

Fatel, R. J. 1970. Iffects of irradiation (high energy -rays) on Cladophorales. I. Chaetomorpha melogonium. Nucleus (Calcutta) 13(2): $111-i 17$. (NSA 25-58153).

Fetrova, J. 1963. The "direct" and "incirect" effects of $i$ onizing radiation on the alga zygnema. Folia Biol. (Pracue) $9(1)$ : 51-59. (NSA 17-17837).

Frasad, B. N. and H. B. E. Godward. 1968. Cytology of irradiated lioufeotia sp. Nucleus (Calcutta) Il: 4349. (NNA 23-33907).

Kalston, H. J. 1939. Immediate and delayed action of $x$-rays on punaliella salina. Am. J. Cancer $37,28 \varepsilon-$ 297. 
Ralston, J. J. 1939. The immediate and delayed action of $x$-rays upon the protozoan Durialiella salina

(abstr.). Am. I. Cancer 37(4): 609.

araiva, li. C. 1972. Influence of gamma radiation (cobalt 60) on cultures of a chlorophyte, Dunaliella bioculata. liar. Biol. 15(1): 74-80. (In Prench) (itis 26-56367).

weuberling, H. -B. 1971. HiEh resistance to $x$-rays of the activity and light-induced activation of NADPdapendent glyceraldehyde phosphate dehydrogenase in Ankistrodesmus braunij: Flanta 98: 270-273. (In German) (NSA 25-55353).

SiEler, W. F. 1965. some effects of accumulated radium on the productivity of algae. Hinal progress rept. for contract AT(11-1)-1023. Utah State Univ., U.. AEC report TID-22322. $31 \mathrm{pp.}$ (NSA 20-26). (Vaucheria, Cladophora).

Simonis, $W$. and $D$. Urbach. 1966. On the action of $x$-rays on photosynthesis and phosphate metabolism of uniceliular green algae (Ankistrodesmus braunii). $\mathrm{Z}$. Pflanzenphysiol. 54: 321-332. (In German) (NSA $21-3388$ ).

Underbrink, A. G., A. H. Sparrow and R. A. Owe:3 . 1969. The fine structure of the alga Brachiomonas submarina Bohlin after $x$ - and $y$-irradiation. Fadiation Bot. $9(4): 241-250$.

\section{Charaphyceae}

(Chara)

Gillet, C. 1963. The action of $x$-rays on Chara vulgaris I. I. Abnormal morphogenesis induced by irradiation. Re $\because$, Cytol. Biol. Vegetales 21: 59-76. (In French) (NS.. 19-36067).

Gillet, $C$. 1963. The action of $x$-rays on Chara vulgaris I. II. Details of effects of irradiation on the nuclear development and cytology of the vegetative plant. Rev. Cytol. Biol. Vegetales 21: 77-96. (In French) (NSA 19-36068). 
Gillet, C. 1963. Action des rayons $\mathrm{x}$ sur Chara vulgaris I. III. Role de l'euploidie dans la reponse de Chara a l'irradiation. Radiation Bot. 2(3/4) 195204.

Gillet, C. 1963. Action des rayons $x$ sur Chara vulEaris L. IV. I elangation, apres irradiation, des cellules internodales de 2 races chromosomiques. Radiation Bot. 3(2): 155-161.

Houtschen, J. 1957. Action of $x$-rays on the growth of internodal celis of the alga Chara vulgaris $L$. Experientia $13(6)$ : 240 . (In French) (NSA II9199).

(Nitella)

Berestroem, R. H. 1962. The effect of 5.3liev Fo2lo alpha particles on the restine membrane potential and ultrastructure of Nitella flexilis. Ann. Ned. ixptl. Biol. Fenniae (Helsinki) 40:45-53. (NSA $18-3509)$.

Isch, H. b. 1966. Dose-dependent Eamma irradiation effects on the restine potential of Nitella flexilis. Radiation Res. 27(3): 355-362.

Esch, H., H. Hiltenburger and 0. Hug. 1964. The effect of electrical potentials of algae cells by Roenten rays. Biophysik $1(4): 380-388$. (In Cerman) (NS.s $18-27092)$. (Nitella).

Gillet, C. 2962. Immediate effect of x-radiation on the cytoplasmic streaming of Nitelia flexilis. Bull. Classe Sci., Acad. Roy. Belg. 48(5): II6I-1168. (In French) (NSA 17-24919).

Gillet, C. 1963. Modification of the velocity of cytoplasmic streamine. induced at a distance, by irradiation in Nitella flexilis. Experientia $19(4): 198-$ 199. (In French) (NSA 17-24921).

Gillet, C. 1964. Permeability of cellular membranes and modification of cytoplasmic current of Nitelia flexilis after irradiation. Intern. J. Radíation Biol. 8(6): 533-539. (In French) (NSA i9-25958). 
Qillet, $C$. 1964. Relations between the dose of $x$-rays applied and the rate of cytoplasmic streamine in Nitella flexilis. Frotoplasma 58: 286-293. (In French) (NSA 19-8900).

iillet, C. 1969. Ke-establishment of cytoplasm and motive force during recovery of cyclosis in Nitella cells after irradiation. Frotoplasma 67: $269-278$. (In French) (NSA 23-45966).

Gillet, C. and L. Klerckx. 1965. Calcium flux from $x$-irradiated Nitella cells. Iife jci. 4: 1561-1565. (NEA 19-4381C).

Vansen, l.-t, 1969. Decay of the radiation effect on if tella at repeated i: radiation compared with the influence on the mechansim of excitation. Atomkernenerfie 14: 207-210. (In German) (NSA 23-29903).

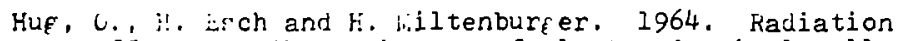
effects on the membranes of plant and animal cells. pp. 213-220. In: Fesponse of the Nervous system to Ionizirse Kadiation. ( $T$. J. Haley and $R$. E. Unider, ed..). Little, Brown and Co., Boston, MiA. (Mitelia).

i.iltenburfer, H., H. bech and O. HuE, 1965. Electrophysiolo ical potentials in plant cells under $x$-irradiation. Bayer. Landwirtsch. Jahrb 42(1): 63-68. (In'serman) (NSA 19-25533). (Limosa and Nitella).

Ozerskiy, 1.. I. 1969. Eiffecte of x-radiation on the permeability of the alea iNitella flexilis to $22 \mathrm{Na}$ ions. radiohiolopiya $9(1): 120-122$. (Enflish transl. AEC$\operatorname{tr}-7024)$. (NEA 23-24765).

(Nitellopsis)

BerEstrom, R. M., R, F. Elafield and M. W. Brenner. 1962. - elective destruction by heavy nuclear irradiation of the cell : mbrane in internodal cells of Nitellopsis obtusa. Ann. Nied. Exptl. Biol. Fenniae (Helsinki) 40 (suppl. 1); 44 pp. (NSA 17-23102). 


\section{Euglenophyceae}

(Euglena)

Bowne, S. W., Jr, and R. R. Mcgough. 1966. Fhototaxis of Euglena with beta and Eamma rays. Exptl. Cell Res. 42: 193-195. (NSA 20-24889).

Cook, J. R. 1963. Ul traviolet-induced aposhlorosis and photoreactivation in two strains of suflena gracilis. Univ. of California. Ios Ane eles, U. S. Aic report II)-18203. $10 \mathrm{pp}$. (NEA 17-15640).

Cook, J. R. and $\mathrm{W}$. Hunt. 1965. Uliraviolet bleachine of synchronized Euglena. Fhotochem. Fhotobiol. 4: 877-880. (NSA 20-16204).

Fahnrich, P. 1965. Inactivation of algae cells with $x$-radiation. Radiation Bot. 5(6): 507-512. (In German) (NSA 20-8701). (Chlorella, Chlamydomonas, Euglena).

Gibor, A. 1969. Effect of ultraviolet irradiation on DNA metabolism of EUElena Eracilis. J. Frotozool. 16(1): 190-193. (NSA 23-45667).

Codward, ii. B. E. 1960. Resistance of algae to radiation. Nature 185(4714): 706. (NSA 14-9349). (Spiropyra, Zyenema, Mougeotia, Cosmarium, EuElena, Eudorina. Chaetomorpha, Prorocentrum).

Hill, H. 2, 1964. UV-inactivation, photoreactivation and the decay of photoreactivability of the greencolony-formine system of Euglena gracilis. Thesis, Brandeis Univ., Wal tham, hiA. (NSA 20-129).

Hill, H. 2, and D. W. Alling. 1969. A model for ultraviolet and photoreactivating light effects in Euklena. Biophysics J. 9: 347-359. (NSA 23-31892).

Hill, H. Z., J. A. Schiff and H. T. Epstein. 1966. Studies of chloroplast development in Euglena. XIII. Variation of ultraviolet sensitivity with extent of chloroplast development. Biophys. J. 6(2): 125-133. (NSA 20-20450). 
Hill, H. Z., H. T. Epstein and J. A. Schiff. 1966. Studies of chloroplast development in EuFlena. $X I V$. Sequential interactions of ultraviolet light and photoreactivating lifht in green colony formation. Biophys. J. $6(2): 135-144$. (NSA 20-18253).

Ishida, li. R. and S. liatsuoka. 1959. Incorporation of P 32 into Euglena cells exposed to $\gamma$-radiation. Bull. Inst. Chen. Research, Kyoto Univ. 37: 405-40?. (WiA $: 4-11452)$.

Kasinova, F. V. 1963. Lffect of $\mathrm{x}$-rays on the dynamic quantity of green and colorless strains of Euelena racilis. Tsitolofiya 5(6): 692-693.

Karinova, G. V. 1964. Influence of different culture conditions in green and colorless cells of Euglena eracilis on their survival after $x$-ray irradiations. Acta Frotozool. 2: 279-285. (In Russian) (NSA 192420\%?).

Kasinova, f. V. 1964. X-ray sensitivity of the ereen and colorless cells of Euglena gracilis Klebs. Radiobiologiya 4(4): 603-606. (English transi. AEC-tr-640?). (NSA $18-4118 ?$ ).

Killebrew, R. and J. A. Winkler, III. 1965. Effects of SOCo irradiation of Euglena gracilis $\left(\mathrm{K}_{1}\right)$. J. liss. Acad. Sci. 11: 205-208. (NSA 20-42906).

Klein, K. H.. il.-F. fiorselli and J. Wansor. 1963. Effect of ultraviolet radiation on growth of autotrophic and oligate heterotrophic cultures of Euglena. J. Protozool. 10(2): 223-225. (NSA 17-33689).

i.atsuoka, 5 . 1963. Structure of the chlorophyll-less mutant of Euglena cell by neutron irradiation. Acta scholae Hed. Gifu 10: 95-99. (NSA 19-8805).

atsuoka, 3. 1964. Effects of radiation on the growth of urlena cells. Bull. Inst. Chem, Res., Kyoto Univ. 42 (1): 1-9. (NSA 18-17501; 21-11067).

i.atsuoka, S. 1965. Effect of Eamma-irradiation on the RlNA content of Euglena celis. Bull. Inst. Chem. Res..

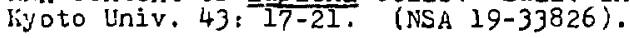


Piatsuoka, S. 1966. Diffusion of some nucleotides into outer medium from non-irradiated and gamma irradiated EuElena cells. Bull. Inst. Chem. Res., Kyoto Univ. 44: 57-65. (NSA 20-28904).

Hatsuoka, S. 1967. Lethal effect of gamma irradiation on Euglena cells in two different growth phases. Buli. Inst. Chem. Res., Kyoto Univ. 45: 12-20. (NSA $21-22822)$.

liatsuoka, S. 1967. Effect of gamma irradiation on uracil-14C incorporation into Euglena cells, Bull. Inst. Chem. Res., Kyoto Univ. 45: 21-29. (NSA 2122823).

Hatsuoka, S. 1967. Effects of gamma irradiation on the protein content of Euplena cells and on the alanine$14 \mathrm{C}$ incorporation into the cells. Bull. Inst. Chem. Res., Kyoto Univ. 45, 30-42. (NSA 21-22824).

liatsuoka, S. 1972. Response of some nucleotides in vivo to gamma radiation on Euglena cells in two different growth phases. Bull. Inst. Chem. Res., Kyoto Univ. 50(1): 38-44. (NSA 26-33597).

Michaels, A. and A. Gibor. 1973. Ultrastructural changes in Euglena after ultraviolet irradiation. J. Cell Sci. 13(3): 799-809. (NEA 29-15906).

Fetropulos, S. F. 1964. Ultraviolet inactivation of chloroplast formation in synchronously dividing tuglena gracilis. Science 145(3630): 392-393. (HSA $1 8 - 3 1 2 3 3 \longdiv { \text { . } }$

Schiff, J. A., H. T. Epstein and H. Iyman. 1961. Ultraviolet inactivation and photoreactivation of chloroplast development in Eugleng. pp. 289-292. In: Frogress in Fhotobiology. (B. Christensen and $B$. Buchmann, eds.). Elsevier, Amsterdam. (NSA 2118186).

Simonis, W. and H. B. Seuberling. 1973. Sensitivity of chlorophyll formation and of increase of NADF-dependent GPD-activity in greening Euglena gracilis to $x$-rays and to other inhibitors of protein synthesis. Atmos. Envir. 13(5): 297-300. (NSA 29-18575). 
Theiss-Seuberline, H. B. 1973. Effect of $x$-rays and inhibitors of protein synthesis on the synthesis of chlorophyll and NADP-linked glyceraldenyde 3-phosphate dehydrogenase in Ereening EuElena gracilis. Arch. itikrobiol. 92(4): 331-344. (In German) (NSA 30-487).

Underbrink, A. G., A. H. Sparrow and V. Pond. 1968. Chromosomes and cellular radiosensitivity - II. Use of interrelationships among chromosome volume, nucleotide content and $D_{0}$ of 120 diverse organisms in predictine radiosensitivity. Radiation Bot. 8(3): 205-238. (Includes Chlamydomonas reinhardi, Rana pipiens, Euglena gracilis, Amphiuma, Necturus).

ilichterman, R. 1955. Survival and other effects following $x$-radiation of the flagellate, Euclena Eracilis (abstr.). Biol. Bull. 109(3): 371 .

\section{Sacillariophyceae}

Braetter, P. 1963. Effect of UV on the diatom Nitrschia linearis. Radiation Bot. 3(3): 287-295. (NSA 185086).

De Salvo, 1. II, and A. B. Cobet, 1974. Control of an estuarine microfouling sequence on optical surfaces using low-intensity ultraviolet irradiation. Appl. icrobiol. 27(1): 172-178. (NSA 29-27000). (Ascidians, barnacles, sessile protozoa, bacteria, diatom).

Hellwie, F. 1963. iffect of roentgen rays on the diatom Hitzschia linearis. Radiation Bot. $3(3): 249-257$. (In German) (NSA 18-5083).

liamshilov, i... 1963. The influence of ultraviolet light on microbiocoenoses of marine protozoa. Doklady Akad. Nauk SSSR (Biol. Sci.) 150(6): 1363-1365. (English transl. pp. 671-673). (Plectonema notatum, diatoms, flagellates, amoebae, ciliates, bacteria, yeast-like cells, Chlorella).

licleod, G. C. 1958. Delayed likht action spectra of several alcae in visible and ultraviolet lieht. J. Gen. Fhysiol. 42(2): 243-250. (Anacystis, Porphyridium. Chlorella, Dunaliella, Bonochrysis, Phaeodactylum. Coscinodiscus . 
jicleod, C. C. and J. AcLachlan. 1959. Sensitivity of several algae to ultraviolet radiation of $253.7 \mathrm{~m} \mu$. Fhysiol. Plant. 12(2): 306-309. (Chlorella, Scenedesmus, Ankistrodesmus, Botryococcus, Flatymonas, Dunaliella, Fhaeodactylum, Skeletonema).

iorton, S. D. and F. H. Deree. 1968. lise of Eamma radiation to control alqae. Environ. Sci. Technol. 2(11): 1041-1043. (Anabena, Aptanizomenon, ricrocystis, Chlorella, Gomphonema).

\section{Dinophyceae}

Jodge, J. J. 1965. siffects of ultra-violet light on the survival and nuclear divicion of dinoflacellate. irotoplasma 59: 485-493. (NEA 19-31867).

$\operatorname{Dod}_{\varepsilon} \mathrm{e}, \mathrm{J}$. D. and i... B. E. Codward, 1963. Some effect: of $x$-rays on the nucleus of a dinoflarellate. Radiation Bot. 3(2): 99-104. (Erorocentrum micans).

Codward, lo. B. L. 1960. Resistance of algae to radiation. Nature 185(4714): 706. (NSA 14-9349). (Spiropyra, Zyenema, Boufeotia, Cosmarium, Euglena, Eudorina, Chaetomorpha, Prorocentrum).

liolnes, R. N. 1967. The dissolution of protoplasm in thecate dinoflacellates by ultraviolet-induced oxidation. Stain Technol. 42: 34-35. (NSA 2231259).

Folikarpov, G. G. and L. A. Lanskaya. 196l, Reproduction of the abundant one-celled alea Frorocentrum micans Ehr. in the presence of $\$ 35$. Tr. Sevastopol. Biol. Stants. 14: 329-333. (English transl. JFRs 20,795: 01: 63-31614). (NSA 17-37022).

\section{Cyanophyceae}

(Anabena)

liorton, S. D. and F, H. Derse. 1968. Use of gamma radiation to control aleae. Environ. Sci. Technol. 2(11): 1041-1043. (Anabena, Aphanizomenon, ijicrocystis. Chlorella, Gomphonema). 
Finfh, R. N. and $H$. N. Singh. 1964. Ultraviolet induced mutants of blue-ireen algae. I. Anabaena cycadeae zeinke. Arch. ikrobiol. 48: 109-117. (NSA 20$35256)$.

sing $h, L$. $A$. and $H$, it. Jingh, 1964. Ultraviolet induced mutants of blue-reen algae. II. Anabaena doliolum Tharadivaja. Arch. i!rotiol. 4E: 11E-121. (NSA 2035257).

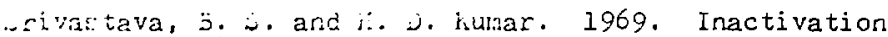
and killin of the blue-treen alra Anabaena doliolum sown on ultraviolet-irradiated culture medium. Radiation Eot. 9(4): 291-295.

(istacystis)

f: 2 to, $y$. i969. Genetic studies of the blue-treen alea, Anacyetis nidularn. Thesis, iniv, of hawail, Honoluidu. 111 pi. (Five 24-36742). (UV irradiation).

inato, $\because$. 1971. Hotorecovery of Eanma irradiated cultures of blue-ireen alca, Anacystis nidulans. Radiation sot. $11(4)$ : 313-316. (WSA 25-49316).

Jritrijev, A. 1. and J. i... Grodzinskiy. 1973. Combined effect of chenical compounds and radiation on the cells of blue-rreen alf a fnacystig nidulans. iticrobioloetiya 42(2): 307-311. (In Russian) (NAA 30-128E6).

Jnitriyev, $A, k$, and $\bar{j}$..... Grodzinckiy. 1973. Ladiosensitipation of blue-rreen ais unacystic nioulane by chersical compound:. tud. Biophys. 35(3): 157-163.

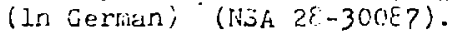

mitrigev, A. S. and J. i... Grodzinskiy. 1974. Influence of a radioseneitizer (monoiodoacetate) on the repair of sublethal dariares in cells of the blue-freen aifa Anacystis nidulane. Fadiobioloriya 14(3): $382-385$.

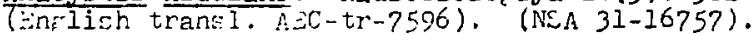

uritriyev, A. F, and D. i... crodzinskiy, 1974. Influence of tome radiosencitizers on Eamma-ray-induced decradation of Jif. in the tlue $-\varepsilon$ reen a $l_{f}$, Anacystis nidulans. sadiation 3ot. 14(1): 11-15. (NSA 30-9747). 
Gearine, F. J., C. van Baalen and F, L. Farker. 1973. Responses of blue-Ereen alrae to technetium. pp. 857-865. In: Radionuclides in Ecosystems. (D. J. Nelson, ed.). U. S. AiC report CONF-710501-P2. Afmenellum quadruplicatum. Coccochloris elbans. Anacystis nidulans).

Kumar, H. D. 1963. Effects of radiations on blue-rreen alsae. I. The production and characterization of strain of Anacystis nidulans resistant to ultraviolet radiation. Ann. 30t. li.s. 27(108): 723-733. (NisA 19-45842).

Kumar, H. D. 1964. Effects of radiations on blue-green al gae. II. iffects on krowth. Ann. Bot. N.S. 26 (112): 555-564. (NSA 19-35966). (Anacystis nidulans, Chlorogloea fritschii).

cleod, G. C. 1958. Delayed lipht action spectra of several ale ae in visible and ultraviolet likht. J. Gen. Fhysiol. 42(2), 243-250. (Anacystis, forphyridium, Chlorella, Dunaliella, Wonochrysís, thaeodactylum, coscinodiscus).

Lhestakov, S. V., V. Hi. Clazer and V. D. Zhevner. 1973. UV-radiation-induced incorporation of thymine and thymidine into the DNA of blue-Ereen algae. Biol. Nauki (5): 107-111. (In kussian) (NSA 30-18896). (Anacyetis nidulans, Synechocystis aquatilis).

Whes takov, S. V., I. V. Llanskaya, V. Li. Glazer and V. j. Zhevner. 1975. Repair of breaks induced by $x$-rays in the DNA of the biue-green alga: Anacystis nidulans. Doklady Akad. Nauk SSSR 222(5): 1217-1219. Tinelieh transl. pp. 218-220). (NSA 33-17355).

Singh, li. N. 1968. Effect of acriflavine on ultraviolet sensitivity of normal, ultra-violet sensitive, and ultra-violet resistant strains of a blue-Ereen alka, Anacystis nidulans. Radiation Bot. 8(4): 355-361. (NSA 22-52028).

Singh, H. N., H. D. Kumar and C. Frakash, 1969. Fostirradiation modification of ultraviolet-sensitivity of normal and nitrofurazone-resistant strains of the blue-green alga Anacystis nidulans. Radiation Bot. 9!2): 105-110. (NSA 23-33905). 
Stoletov, V. N., V. D. Zhevner, D. V. Garibyan and \%. v. Shestikov. 2965. Piement inutations in Anacystis nidulans induced by nitrosomethylurea. Genetika (6): 61-66. (In Russian) (NSA 20-28958). (UV and $x$-irradiation).

(others)

Balloni, A., G. Florenzano and $\bar{k}$. iraterassi. 1965. Influence of irradiated nitrogen on the nitrocenfixine activity of blue-ereen alqae. inn. Inst. Fasteur 109(juppl.): 62-67. (In French) (NSA 2020408).

.h thardt, J. 1. 1973. Effect of $\gamma$-irradiation on the respiration of unicellular algae. Compt. Rend. Eoc. 3iol. 167(11): 1529-1531. (In French) (NSA 3018879). (Ehormidium foveolarum. Dunaliella salina).

earing, F. J., C. van Baalen and F. I. Farker. 1973. Response of blue-freen algae to technetium. pp. 857-865. In: Radionuclides in Ecosys tems. (D. J. iielson, ed.). U. S. AEC report CONF-710501-E2. (NSA 2E-29831). (Afmenellum quadruplicatum. cocco hloris elabens, Anacys tis nigulans).

Coiubkova, ... C. and D. F. Grodzinskiy. 1972. Interccllular interactions and recovery of a population of the blue-green alga Flectonema boryanum after ramma irradiation. Radiobiolngiya 12(1): 144-148. (inglish transl. AiC-tr-7316). (NSA 26-50831).

kamshilov, li. i.. 1963. The influence of ultraviolet light on microbiocoenoses of miarine protozoa. Doklady Akad. Nauk SSSR (Biol. Sci.) 150(6): 1363-1365. (inclish transl. pp. 671-673). (Electonema notatum. diatoms, flaEellates, amoebae, cjiliates, bacteria, yeast-like cells, Chiorella).

lraur, i.. F. 1969. Resistance of blue-Ereen algae to 60 co amma radiation. Radiation Bot. $9(6): 481-4 \varepsilon 9$. (Nis 24-12331). (23 species).

kraus, i.. t, 1975. Wolecular mechanisms for Diva repair in the blue-treen alfae. pp. 525-528. In: iolecular l.echanisms for Repair of DNh. Fart B. (F. C. Hanawalt, ed.). Flenum fress, IVY. (EKA 1-7544). (Includes (amma radiation). 
Yutlakinnedov, Yu. A. and $\ddot{z}$. :. Crodzinskiy. 1973. Thenomenolorical peculiarities of the photomodification of radiation damare in the blue-freen alga i-lectonema borjanum, Kadiobiologiya i3(3): $448-451$.

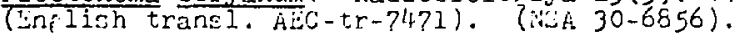

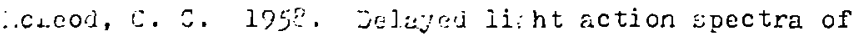
reveral al at in vi:ible ara liltraviolet licht. $\therefore$ "en. Fhyiol. 42(2): 243-250. (Enacystic, forjyridiug, Chiorellá, Dunaliella, onochrysis, Phaeodactylun, coscinodiscus

..orton, 3 . D. and 1. H, Dersa. 1968. Use of ramma radiation to control alrae. Environ. sci. Technol. 2(11): 1041-1043. (ivia 23-5057). (Anabaena, Bohanizomenon. icrocietis, chlorelia, Comphonema).

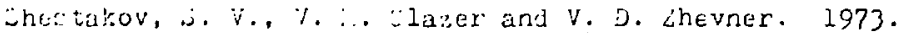
liv-radiation-indidced incorporation of thymine and thymidine into the jiv of biue-i reen alrac. jiol. Maliki (5): 10?-11. (In Lussian) (vist 30-18896). (inacyotig nidulang, iuschocyetis aquatilij).

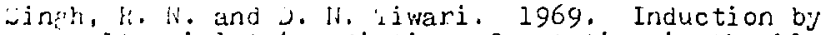
ultraviolet irradiation of mutation in the bluereen alfillostoc linckie (Roth) Born. et Flah.

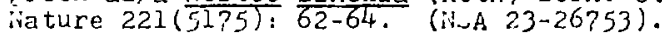

irivastava, B. S. 1369. L'ltra-violet induced fildation: to frowth factor requircment and pericillin reaistance in a blue-freen alfa. Arch. i.ikrobiol. 66: 234-238. (iis 25-26?12). (whormidium mucicola).

Thompson. J. i. 1974. studies on 31 cyanophyta species. I. Amino acid analyses. II. iffects of irradiation with $60_{C o}$. Jicsertation, univ. of Houston. Ilouston, $\mathrm{T} X$. $170 \mathrm{pp}$. (Univ. l.j.crofilms order ivo. $74-21,400)$. (NSA $31-708)$.

Van Baalen, $\mathrm{C}$. 1968. 'the effects of ultraviolet irradiation on a coccoid blue-green alea: Survival, photosynthesis, and photoreactivation. Flant Fhysiol. 43(10): 1689-1695. (NiA 23-5056). (Agmenellum guadruplicatum). 


\section{Wiscellaneous}

Anderson, J. B., E. C. T'sivoplou and S. D. Shearer. 1963. isfects of uranium mill wastes on biological fauna of the Animas River (Colorado-New liexico). pp. 373383. in: Radinecolofy. (V. Schultz and A. if. kilement, ur.. eds.). Peinhold Publishing Corp., NY. (Bottom fauna, Salmo Eairdnerii, algae).

An:clovic, J. $d$. 1965. Some effects of accumulated radium on the productivity of algae. Thesis, Utah Etate Viniv., Logan, Utah. 149 pp. (NSA 20-14381). (3) enera).

Einte, 1. R. 1952. Effects of radiation on marine al Eat. . Cell. Comp. Fhysiol. 39(Suppl. 2): 11-18. (Vield observations in South facific test area).

jown, F. A., Jr., li. A., webb and th. F. Bennet. 1958. Comparisons of some fluctuations in cosmic radiation and in organismic activity during 1954, 1955 and 1956. Am. J. Physiol. 195(1): 237-243. (Includes Lca nuEnax, Triturus, Fucus, quahog).

Joshi, Y. A., S. T'. Malreja and F. S. Rao. 1968. Froduction of hifh quality agar by amma irradiation of ccaweeds. Indian J. Technol. 6: 275-277. (NSA 2350934). (Gracilaria milardetii, Hvpnea musciformis).

Joshi, Y. A. and F. S. Rao. 1967. Radiation induced eshancement of gel streng,th in red seaweeds. Indian f. Chem. 5: 342-343. (NSA 22-10885). (Gelidiella acerosa, G. micropterum, cracilaria miliardetii).

Jucorf, H. S. 1965. Recovery from radiation-induced divicion block in protists. Illinois univ., U. $\mathrm{S}$. $A-C$ final report for contract AT(11-1)-878, 'c00-87815. $17 \mathrm{pp}$ (NSA 19-21856). (Brachiomonas submarina, Chilomonas paramecium).

dhrhardt, J. F. 1973. Effects of acute and subacute rama radiation on photosynthetic release and respiraion of three unicellular marine al kae. Thesis, *Crdeaux-1 Univ.. 33. france. $119 \mathrm{pp}$. (FRNC-THisoe). (In French) (WSA 29-15911). 
Ehrhardt, J. F, and I. Leguay. 1971. Immediate effects of a sub-acute gamma irradiation on the photosynthesis of unicellular algae. pp. 141-144. In: Scientific . Sork, 1971. Centre de Fecherches du Service de Sante des Armees, Clamart, France, report FRNC-R-19. (In French) (NSA 28-30076). (3 species).

iugster, J. G. 1964. Suradiation experiments concernine the concept of the natural radiation environment. Aerosp. lied. 35(6): 524-526. (Artemia, Ereen alea).

Lileva, Ye. A., H. A, 'limofeyeva and H. V. TimofeyevFesovskiy. 1964. The effect of continuous irradiation of a camma rield on the biomass of freshwater aíai periphyton. Doklady Akad. Nauk SSSK 156(2): 455-456. (English transl. pp. 393-394). (iNSA 18$32831)$.

cociward, $\therefore$. B. i. 1962. Invisible radiations. pp. 551566. In: Physiology and Biochemistry of Alfae. (R. A. Lewin, ed.). Academic Fress, NY.

Jayson, G. G. and D. C. Pickerine. 1962. The effects of ionizine radiations on the absorption of bivalent ions by ereen filamentous algae (abstr.). p. 195. In: Second Intern. Confress Fadiation Fesearch. Silver ind Documentary Fublications, Itd.. London.

Katsuura, K., S. Euzuki and $\mathrm{T}$. Okano. 1962. Effect of $x$-ray irradiation on red seaweeds. Koeyo kacaku Zasshi 65: 10?6-10?8. (NSA 1?-27132). (Bucheuma spinosum, Gracilaria confervoides).

O'Kelley, J. C. 1976. The potential biological effects of depleted uranium on range $C-74$ upon the alkal flora of Rocky Creek on Iigin Air Force Base. Final report Nov 1974 - Jul 1976 . Alabama Univ., Univsity, AI. Contraci 20 B635-75-C-0039. $50 \mathrm{pp}$. (AD-A-040809). (ERA 3-5295).

Fetri, V. N. (ed.). 1970. Effects of ionizing radiation on hydrobionts and land plants. Ir. Inst. Ekol. Rast. Zhivot. (74): 1-98. (In Russian) (NSA 25-24462). (isox iucius, Tunica tunica, Lvmnaea stagnalis, alqae). 
Razyulite, R. N., K. K. Yankyavichyus, S. F. SaulenayteBudriene and G. Yu. iankavichyute. 1973. Influence of $\gamma$-rajs and temporary factors on planktonic bioceonoesis. pp. 73-77. In: Radioecology of water Organisms. III. The effects of Ionizine Radiation on ilater Oreanisms. (G. F. Andrushaitis, ed.). (Enelish trans l. AEC-tr-7592). (NSA 31-11540). (13 species of altae, 8 species of zooplankton).

Gaks, i. l... and J. J. Lee. 1973. Radiosensitivity and linht quality responses of salt marsh epiphytic alfac. op. 1c23-1028. In: radionuclides in icosystems. (D. J. Nelson, ed.). U. S. AisC report CONT-710501-1.2.

Saks, it. $\because$. and J. J. Lee. 1973. The differential sensitivity of various species of salt marsh epighytic alpae to ionizine radiation and thermal stress. pp. 565-570. In: Radioactive Contamination of the arine invironment. Intern. Atomic Enerfy Agency, Vienna, Austria, publication STI/FUB-313.

Sirler,.$?$. 1965. Some effects of accumulated radium on the productivity of algae. Final progress report for contract Al(11-1)-1023. Utah State Univ., U. S. A.C report IID-22322. 31 pp. (NSA 20-26). (Vaucheria, Cladophora).

シ. PLNGI

\section{Fhycomycetae}

Coonill, T. Y. and K. A. Deerinf, 1969. Ultraviolet lient inactivation and photoreactivation of Blastocladiella emersonii. Radiation Res. $39(2): \sqrt{374-385}$. (WEA 23-41500).

Deerine, R. A. 1968. Radiation studies of Blastocladiella emereonii. Radiation Res. $34(1): 87-109$. 


\section{C. "HIGHER" FLANTS}

Bukatsch, F. 1938. The effects of radon and mineral materials upon photosynthesis of submerted plants. lilanta 28: 264-274. (Chem. Abstr. 32: 7515).

Dijkman, I... J., li. I. Boss and E. R. Russell. 1964. ixtension of life span of Iemna perpusilla clone 6746 by ultraviolet irradiation. Fadiation Fes. $22(4): 662-667$. (NSA 18-35366).

Jorris, B. J. 1964. Fopulation variability and response to ionizing radiation in Isoetes melanospora inrelm. Thesis, Emory Univ., Atlanta, GA.

Feldmann, A. 1969. Contributions to radiation stimulation. IT. 'l'he effect of leneth of day on the radiation induced increase in growth of Lemna minor $i$. Radiation Bot. $9(6): 459-471$. (In German) (itsis 2l12327 ).

تeldmann, A. 1971. Contributions to radiation stimulation. III. Influence of temperature on radiation-induced Erowth stimulation in Lemna minor $L$. Radiation jot. Il(1): 59-65. (In German) (N5A 25-35248).

Feldrann, A. 1974. Radiation induced mitotic delay and ctimulation of Erowth. Stimul. Newsl. (6): 10-16. (ivi 32-28232). (Lemna minor; Lepidum sativum).

Feldmann, A. 1975. Contributions to radiation stimulation. IV. The influence of variations in light and temperature as well as time of irradiation on radiation-induced frowth stimulation in Eerna minor $I$. Radiation 3ot. 15(1): 49-58. (In German) (NSA 3217439).

Gertsuskiy, D. $\mathrm{I}$, and L. V. Alekseyenko. 1971. Biolurical effects of protons and Eamma radiation on waterciess seeds. Radiobiologiya II(4), 575-579. (wnglish transl. AEC-tr-7304). (NSA 26-36354).

Grechishkin, S. V. 1934. The biological effect of irradiation on ilodea densa. Bacterium ponticum and Saccaromyces cerevisiae. Bot. $2 \mathrm{~h}$. 19(6): 527-533. 
Harrison, F, L, and J.J. Koranda. 1973. Tritiation of aquatic animals in an experimertal freshwater pool. op. 425-434; In: Radionuclides in Ecosystems. (D. J. Nelson, ed.). U. S. ASC report CONF-?10501Fl. (NSA 26..9484). (Clams, crayfish, Ëoldfish, cattails, Fithophora, plankton).

hieizorunn, $i$. $V$, ard $k$. Daugherty. 1935. Indirect effects of radiation on Elodea leaves. Eiol. Bull. 69(2): 279-286. (Elodea Sanadensis).

Sasinov, V. B. 1966. Fate of reproduction and survival of duckweed Lemna minor after gamma irradiation. Radiobiolociya 6(4):605-612. (English transl. AÉC$\operatorname{tr}-6773$ ). (NSA $21-22787$ ).

irat:inov, V. B. 1966. Reversed development order of corymbs in irradiated colonies of Lemna minor. Doklady Akad. Nauk SSSR 167: 201-204. (In Russian) (INA 21-9017).

iasinov, V. B. and G. V. Kasinova. 1971. Dynamics of radiation damage to the plant orfanism with the lesser duckweed as an example. Radiobiologiya 11(4): 580586. (Enclish transl. AEC-tr-?304). (NSA 26-36355).

liatinov, V. B. and G. V. Kasinova, 1971. Farmanently polymorphic clones of duckweed as a model for study of come problems of developmental biology. Ontogenez 2(6): 555-564. (English transl.. Sov. J. Develop. Biol. 2(6): 441-448). (NSA 28-5961). (X-irradiation).

Iasinov, V. B. and G. V. Kasinova. 1971. Radiationinduced deformities in vegetatively reproduced duckwecd. Doklady Akad. liauk SSSR 199(2): 460-463. (In Fussian) (NSA 26-15429).

ieinerte, $\because$. F. 1968. ixperiments on the irradiation of a duckweed (Lemna minor $I$.) with $\gamma$-rays and fast neutrons. Fadiobioloeiya 8(i): 156-15?. (EnElish transl. AiEC-tr-6914). (NSA 22-47636).

Leinerte, $\therefore$ P. 1969. Crowth of higher freshwater plants after irradiation with gamma-rays and fast neutrons. Latv. FSF '2inat. Akad. Vestis (11): 68-72. (In Pussian) (NSA 24-36852). (Lemna minor, Elodea canadensis, ivriophyllum spicatum). 
Leinerte, H. F. 1969. Influence of extsrnal $\gamma$-irradiation of higher aquatig plants on their accumulation of $90 \mathrm{Sr}, 137 \mathrm{Cs}$, and $144 \mathrm{Ce}$. Fadiobiologiya 9(3): 427-432. (English trans 1. AEC-tr-7026). (NSA 249968). (Lemna minor, Ceratophyllum demersum, Elodea canadensis).

ahar, II. 1974. Combined effects of cobalt-60 irradiation and selected herbicides on spirodela polyrrhiza. Dissertation, Univ. of lichican, Ann Arbor. $121 \mathrm{pF}$. (Univ. Vicrofilms order No. 74-25,259). (NSA 31$3850)$.

ivordenskiold, $K$. 1962. Studies of meiosis in Iuzula purpurea. Hereditas 48(3): 503-519. (NSA 18-75).

Nordenskiold, H. 1963. A study of meiosis in the progeny of $x$-irradiated Iuzula purpurea. Hereditas 49(1-2): 33-47. (NSA 18-76).

Timofeyeva-Resovskaya Ye. A. and iv. V. Timofeyev-Resovskiy. 1966. Influence of various doses of $60^{\mathrm{Co}}$ gama-rays on duckweed and water thyme. pp. 235-237. In: Effect of Ionizing Fadiation on heredity. (Il. F. Dubinin, ed.). hoscow, Publ. House Acad. Sci. USSI. (In Russian) (NSA 22-21632).

Vlasyuk, F.A. and N. I. Bidzilya. 1958. The influence of - particles of radioactive isotopes on size variation on chioroplasts of Elodea canadensis. Dokilady Akad. Nauk SSSR 119(1): 65-67. (English transl. pp. 130-133). (NSA 12-10306). 


\section{ANIMIALS}

A . INVERTEBRATES

\section{Frotozoa}

(isiroeba)

Sychkovskaya, I. B. and G. K. Ochinskaya. 1972. Dynamics of post-radiation death in amoebae related to the irradiation dose. Tsitologiya 14(1): 137-140. (In Russian) (NSA 27-20020).

Bychkovskaya, I. B. and G. K. Ochinskaya. 1973. Viability of the propeny of irradiated cells (experiments on Faramecium caudatum and Amoeba proteus). Radiobiolofiya $13(2): 211-215$. (English transi. AeC-tr-7444). (ISA 29-24844).

Bychkovskaya, I. B., G. K. Ochinskaya and A. I. Kyumtreva. 1971. Sitrificance of the toxic effects of an irradiated medium in the postradiation cleath of cells. Communication I. Experiments on Amoeba protelis. Raciobioloriya ll(2): 235-238, (English transl. AsCtr-7269). (NSA 25-44942).

Chatter.jee, S. 1968. $X$-ray induced changes in the cell body of amoeba. L. Biol. 116: 68-80.

Chatterjee, S. and S. K. Shattacharjee. 1975. Effect of near ultraviolet and visible light on amoeba. J. Cell sci. 19(1): 117-126. (NAA 33-9591).

Janiels, $E$. H. 1951. Studies on the effect of x-irradiation upon Eelomyxa carolinensis with special reference to nuclear division and plastmotany. J. Exptl. 2001. 117(1): 189-209. (NSA 5-6058).

Daniels, E. W. 1954. Cell division in the giant amoeba, Pelomyxa carolinesis, followine $x$-irradiation. II. analysis of therapeutic effects after fusion with nonirradiated cell portions. J. Exptl. Zool. 127(3): 427-46I.

Daniels, E. W. 1955. X-irradiation of the Eiant amoeba, felomyxa illinoisensis. I. curvival and cell division following exposure. Therapeutic effects of whole protoplasm. J. Exptl. Zool. 130(2): 183-19?. 
Daniels, E. W. 1956. Recovery from lethal x-radiation injury in amoebae after injection of centrifugal portions of nonirradiated cells (abstr.). Radiation Res. 5(6): 604-605.

Daniels, E. W. 1958, X-irradiation of the giant amoeba, Pelomyxa illinoisensis. II. Further studies of recovery following supraletha? exposure. J. Exptl. Zool. $137(3)$, 425-442. (NSA 13-1918).

Daniels, E. W. 1959. Micrurgical studies on irradiated Pelomyxa. Ann. New York Acad. Scie. 78(2): 662-674. (NSA 13-19786).

Daniels, E. W. and H. H. Vogel, Jr. 1958. Frotective component in nonirradiated protoplasm of amoeba. Proc. 2nd Intern. Conf. on the Peaceful Uses of Atomic Energy 23: 29-33. (NSA 12-14502).

Daniels, E. W. and H. H. Vogel, Jr. 1959. Effects of nonirradiated protoplasm on recovery of amoebae exposed to supralethal doses of fission neutrons. Radiation Res. 10(5): 584-596. (NSA 13-13197).

Daniels, E. W. and I. E. Roth. 1961, X-irradiation of the giant amoeba, Pelomyxa illinoisensis. III. Electron microscopy of centrifuged organiems. Radiation Res. $14(1)$ : 66-82.

Daniels, E. W. and E. P. Breyer. 1970. Recovery of supralethally $x$-irradiated and nitrogen mustard (HN2)treated amoebae. Intern. J. Radiat. Biol. 18(2): 179-187. (NSA 24-51022). (Pelomvxa illinoisensis).

Daniels, E. W. and E. P. Breyer. 1970. Rescue of supralethally $x$-irradiated amoebae with nonirradiated cytoplasm. Radiation Res. 41(2): 326-341. (NSA 24$17127)$.

Daniels, E. W. and E. P. Breyer. 1971. Supralethally $x$-irradiated amoebae treated with nonirradiated, homogenized protoplasm. Radiation Res. 46(1): 8588. (NSA 25-32521). 


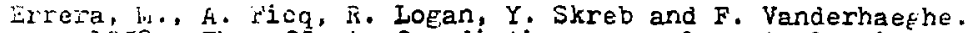
1958. The effect of radiation on nucleocytoplasmic relations in living cells. Proc. 2nd UN Intern. Conf or the Peaceful Uses of Atomic EnerEy 22: 475-478. (Amoeba, Acetabularia).

Fiedrich-ire:- a. $\mathrm{K}^{r}$, and F. Kaudewitz: 1953. iethal afte effects atter incorporation of Fja in Amoeba proteus

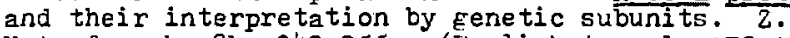
Naturforsch. 8b: 343-355. (ËElish transl. AEC-tr4401). (Nos 15-7199).

Iverson, $\bar{k}$. W. 1958. Nuclear transfer studies on ultraviolet-irradiated Amoeba proteus. Exptl. Cell Res. 15(1): 268-270.

Kal niy, V. S. 1967. Radioresistance of Amoeba proteus in relation to irradiation conditions and mitotic etates. Tsitologiya 9: 1535-1542. (In Fussian) (NSA 22-36351).

Kal'niy, V. S. 1969. A comparative radiosensitivity of two strains of Amoeba proteus. Tsitologiya l].(1): 68-71. (In Russian) (NSA 23-35857).

hiharlamova, I. A. 1972. Investigation of the radiobiolofical reactions in Amoeba proteus. Communication 1. Survival, delay of cell division, and forms of death after eamma irradiation of radiosensitive and radioresistant strains. Radiobioloeiya 12(3): 401407. (Enelish trans1. AEC-tr-7402). (NSA 27-17535).

iharlamova, L. A. 1973. Investigation of the radiobiological responses in Amoeba proteus. Radiobiologiya 12(6;: 934-937. (Enelish transl. AEC-tr-7421). (NSA $28-2840)$.

Wharlamova, I. A. 1973. Investigation of the radiobiolofical responses in Amoeba proteus. Communication 3. JNA content influence of modifying factors on the survival of amoebas after irradiation. Radiobiolofiya 13(2): 260-264. (inglish transl. Aic-tr$7444)$. (NSA 28-24845).

roror odina, Yu. V. and V. I. Korogodin. 1971. Radiobiolofical reactions of amoebae with few chromosomes. kadiobiologiya 11(6): 865-870. (Enelish transl. Aec$\operatorname{tr}-7307$ ). (NSA 26-41217). 
Korogodina, Yu. V., Ye. N. Sokurova, I. A. Kharlamova and $V$. I. Khaustov. 1973. Nucleic acid contents in some species of amoebae differing in their radiosensitivity. Tsitologiya 15(5),613-616. (In Russian) (NSA 28-21578).

hookerjee. S. and S. Chatterjee. 1970. Formation of supernumary surface layers on irradiated amoebae. Current Sci. (India) 39,468-469. (NSA 25-11249).

Ord, If. J. and J. F. Danielli. 1956. The site of damage in amoebae exposed to $x$-rays. Quart. J. Microscop. Sci. 97. 29-37.

Faribok, V. F., V. S. Kal'niy and T. B. Ikonnikova. 1968. The effect of dose rate during $x$-irradiation of Amoeba proteus. Tsitologiya 10, 1479-1484. (NiA $23-14244)$.

Fechenko, 1. F. 1922. The effect of radium rays on amoeba. Vestn. Rentgenol. Radiol. 2(1): 39-48.

Read, J. 1963. Restoration of supralethally irradiated amoebae. Intern. J. Radiation Biol. 7(1): 101-102. (NSA 18-19637).

Rinaldi, R. A. 1959. The induction of pinocytosis in Amoeba proteus by ultraviolet radiation. Exptl. Cell Res. 18(I): 70-75.

Samoilva, K. A. and V. A. Krylenkov. 1973. Comparison of the effects of far and near ultraviolet radiation and their photoreactivation on some protozoa. itud. Biophys. 36-37: 191-203. (NSA 29-778). (Earamecium caudatum. Amoeba proteus).

skreb, Y. 1968. The effect of certain aEents on radiosensitivity of amoeba and on recovery from radiation damage. Arh. Hig. Rada Toksikol. 19(Suppl. 1): 117123. (NSA 24-7985).

Skreb, Y, and H. Errera. 1957. Effect of ultraviolet rays on nucleated and non-nucleated fragments of amoebae. Exptl. Cell. Res. 12(3): 649-656.

Skreb, Y. and N. Skreb. 1960. Effects of U.V. rays on respiration of ameeba fraements. Biochim. Biophys. Acta $39(3)$ : 540-541. (In French). 
Skreb, Y. and B. Gavrilovic. 1962. Influence of irradiation on nucleo-cytoplasmic interactions in Amoeba proteus (abstr.). p. 95. In: Second Intern. Congress Radiation Research. Silver End Documentary Fublications, Ltd., London.

ikreb, Y. and \% Horvat. 1966. Influence of gamma-radiation ias line lrieorporation of $14 \mathrm{C}$-adenine and $14 \mathrm{C}$-pheri, lalanine into whole amoebae and nucleate and anucleate amoeba fragments. Exptl. Cell Res. 43: 639-644. (iviA 21-10797).

$\approx k r \in b, Y$. and D. Horvat. 1971. Riodification of the effects of radiation on amoebas. I. Sensitizing action of actinomycin $D$ before eamma irradiation. Intern. J. Radiat. Eiol. 20(2): 129-135. (In French) (NSA 264692).

$3 k r e b, Y_{.}$, [.. Eger and D. Horvat. 1965. Effects of gamma rays on the ribonucleic acid and protein content of arnoeba. Biochim. Biophys. Acta 103(1): 180-182. (Enelish trans1. U. S. AEC report ANL-Trans -475 ). $4 \mathrm{pp}$. (NEA 19-383i; 21-28686).

fhoms on, J. F. and E. W. Daniels. 1961. Cytochrome oxidase in radiosensitive and radioresistant amoebae. Froc. Soc. Expt1. Biol. Med. 107(4): 916-919. (NSA 15-30488).

Jichterman, $R$. 1957. X-irradiation of the Eiant amoeba, Chaos chaos (abstr.). Biol. Bull. $113(2): 359$.

wichterman, R. and C. M. honegger. 1958. Action of $\mathrm{x}$-rays on the two common amoebas, Chaos diffluens and Chaos chaos. Froc. Fenn. Acad. sci. $32: 240-253$.

(Blepharisma)

Giese, A. C. 1965. Blepharisma intermedium: ultraviolet resistance of piemented and albino clones. Science 149(3683): 540-541. (NSA 19-36073).

Ciese, A. C. 1973. Blepharisma: The biology of a lightsensitive protozoan. Stanford Univ. Press, Stanford. CA. $x, 366 \mathrm{pp}$. 
Giese, A, C., B. McCaw and R. Cornell, 1963. Retardation of division of three ciliates by intermittent and continuous ultraviolet radiations at different temperatures; J. Gen. Physiol. 46(5), 1095-1108. (NSA 20-8674). (Paramecium caudatum. Blepharisma iaponicum, Colpidium colpoda).

Hirshfield, H. I., A. M. Zimmerman, J, V. Landau and D. Marsland. 1957. Sensitivity of UV-irradiated Blepharisma undulans to high pressure lysis. J. Cell. Comp. Physiol. 49(2): 287-294.

\section{(Colpidium)}

C: owther, J. A. 1926. Action of X-rays on Colpidium colpoda. Froc. Roy. SOc. London 100(B 704): $390-404$.

Giese, A. C., B. LicCaw and $\bar{h}$. Cornell. 1963. Retardation of division of three ciliates by intermittent and continuous ultraviolet radiations at different temperatures. J. Gen. Physiol. 46(5), 1095-1108. (NSA 20-8674). (Paramecium caudatum. Biepharisma japonicum, Colpidium colpoda).

Taylor, C. V., J. O. Thomas and ki. G. Brown. 1933. Studies on protozoa. IV. Lethal effects of the $x$-radiation of a sterile culture medium of colpidium camphylum. Fhysiol. Z001. 6(4): 467-492.

(Colpoda)

Bridgman, A. J. and R.F. Kimball. 1954. The effect of $x$-rays on division rate and survival in Tillina magna and Colpoda sp. with an account of delayed death. J. Cell. Comp. Physiol. 44(3): 431-445.

Calkine, J. and G. Griggs. 1969. Photoreactivation of U.V. reactivation in protozoa. Photochem. Photobiol. 10: 445-449. (NSA 24-14574). (Colpoda cucullus). 
Giese, A. C. and F. Rushbrook. 1974. Effects of simulated space ultraviolet and visible radiation upon cysts of Colooda inflata. Fhotochem. Fhotobiol. $19(4): 277-283$. (NSA 30-7114).

GriEes, H. G. 1969. Studies on recovery of colpoda from potentially lethal $x$ - and ultraviolet radiation induced Uanage. Thesis, Univ. of Kentucky, lexington. $166 \mathrm{pp}$. (Univ. Viicrofilms Order No. 70-12,354). (N'A 25-13342).

rozlov, A. A. 1971. Effect of background doses of Eamma irradiation on the rate of division of infusorians. sadiobiologiya 11(6): 935-937. (English transl. AiCtr-7307). (NEA 26-41219). (Colpoda sp.).

liozlov, A. A. 1974. Influence of preliminary irradiation of the nutrient medium and infusoria on the division rate. Soobshch. Akad. Nauk Gruz. SSR 74(1): 213-215. (In Russian) (NSA 30-21351). (Colpoda sp.).

Lozina-Lozinskiy, I. K. and 2. I. Uspenskaja. 1868. The influence of ultraviolet irradiation (2537 $\AA$ ) on infusoria Colpoda maupasi. Acta Protozool. 6(26): 297-307. (NSA 24-34598).

avljanova, I. I. 1966. On the reaction of infusoria of the genus Colpoda to $60 \mathrm{Co}$ gamma radiations. Fedobioloeia 6:129-139. (In German) (NEA 21-16543).

(inplotes)

immermann, D. 1971. Horphology and development of the macronuclei of the ciliates Stylonvchia mytilus and Euplotes aediculatus. Chromosoma 33(2), 209-238. (NSA 25-58096). (X-rays; autoradiographic experiments).

Hilderbrand, E. and H. Stieve, 1972. Fermeability of the protozoan cell membrane to water and ions under the action of ultra-violet lieht. Z. Naturforsch 27b(10): 1243-1257. (In German) (NSA 27-5546) (Faramecium. Euplotes, Opalina).

Nise, B. N. 1965. Effects of ultraviolet microbeam irradiation on morphogenesis in iuplotes. J. Exptl. 20ol. 159(2): 241-26́?. (NSA 20-5345). 
Hise, B. N. 1965. Norphogenes is in Euplotes. Thesis, Yale Univ., New Haven, CT. Pts. I, II. $147 \mathrm{pp}$. (NSA 20-10696).

(Paramecium)

Alpatov, H. H. and A. W. Shoobina. 1962. The influence of drugs upon the blood serum toxicity acquired under the action of ionizing radiation. Byull. Eksptl. Biol. i Med. 53; 28-31. (In Russian) (NSA 16-23440). (Paramecium).

Back, A. 1939. Sur un type de lesions produites chez Faramecium caudatum par les zayons $X$. Compt. Rend. 500. Biol. $131(19):$ 1103-1106.

Back, A. and 1. Halsberstaedter, 1945. Influence of the biological factors on the form of roenteen-ray survival curves, Experiments on jaramecium caudatum. Am. J. FoentEenol. Kadium Thi,rapy 54: 290-295.

Bychkovskaya, I. B. and G. K. Ochinskaya. 1972. Viability of profeny of irradiated Paramecia during vegetative reproduction and after conjugation. Radiobioloriya 12(5): 767-770. (English transl. AEC-tr-7415). (NSA 27-27984).

Bychkovskaya, I. B. and G. K. Ochinskaya. 1973. The significance of the toxic effect of an irradiated medium in the postradiation death of cells. 2 . Experiments on Paramecium caudatum. Radiobiologiya 13(5): 680-685. (Enelish transl. AEC-tr-7507). (NSA 29-27113).

Bychkovskaya, I. B, and G. K, Ochinskaya. 1973. Viability of the progeny of irradiated cells (experiments on Faramecium caudatum and Amoeba proteus). RadiobioIOElya 13(2):211-215. (English transi. Aic-tr-7444). (NiA 29-24844).

Bychkovskaya, I. B., O. V. Malinovskiy, G. K. Ochinskaya and $A$. I. Filippov. 1972. Stability of radiation injury in cell population of faramecium caudatum. Doklady Akad; Nauk SSSR 205(1): 213-215. (In Russian) (NSA 27-5552). 
Calkins, J. C. 1963. Detailed study of the lethal effects of $x$-rays and ultraviolet light on two ciliate protozoans. Thesis, Univ. of Texas, Austin. $139 \mathrm{pp}$. (NSA 20-36661). (Earamecium aurelia, Tetrahymena pyriformis).

Calkins, J, 7963. Variation of radiation sensitivity of rarameclum aurelia as a function of time of irradiation in the interdivision growth cycle. Nature 198(4881): 704. (NSA 17-23125).

Calkins, J. 1965. A stuay of the time course of recovery of Paramecium aurelia from the lethal effects of $x$-rays. Radiation Res. 26(1): 124-131. (NSA 1945978 ).

Calkins, J. 1965. iffect of $x$-ray dose on the frowth rate and delay of the first post-irradiation division in a strain of Faramecium aurelia. Nature 205(4970): 511-513. (INA $19-15137$ ).

Calkins, J. 1966. An alternative multi-target equation useful for fittine survival curves of $x$-ray irradiated protozoa. Nature 209(5019): 172-173. (NSA 2016273). (Faramecium).

Croute, F., J. F. Soleilhavoup and H. Flanel. 1972. iffect of autogamy on the sensitivity of cells to natural ionizing radiations. Compt. Rend. Soc. Biol. 166(6): 948-951. (In French) (NSA 28-8479). (raramecium).

Croute, F., Y. Blanquet, R. Tixador and J. F. Soleihavoup. 1972. Effect of continued radioprotection on successive cycles in Faramecium aurelia. Compt. Rend. soc. Biol. $166(8): \frac{1170-1173}{117}$ (In French) (NSA 28$24694)$.

Croute, F., H. Planel, J. F. Soleihavoup and F. Blanquet. 1973. Isolation of atocks of Paramecium aurelia of different radiosensitivities towards natural ionizing radiation. Compt. Rend. Soc. Biol. 167(12): 19841989. (In French) (NSA 31-14300; 31-26055).

Janiel, G. E. and H. D. Fark. 1953. Glutathione and $x$-ray injury in hydra and Earamecium. J. Cell. Comp. Fhysiol. $42(3)$ : $359-367$. 
Daniel, G. E. and H. D. Park. 1953. Reproduction in Paramecium as affected by smali doses of $x$-ray and beta radiation. Proc. Soc. Exptl. Biol. Med. 83(4): $662-665$.

De Haller, S. 1968. Experimental morphogenesis in the ciliates, Effects of UV-irradiation in the differentiation of the cilia of Faramecium aurelia. Rev. Suisse 2001. 75: 583-588. (In French) (NSA 24-832).

Ehret, C. F. 1959. Induction of phase shift in cellular rhythmicity by far ultraviolet and its restoration by visible radiant energy. pp. 541-550. In: Fhotoperiodism and Related Phenomena in Plants and Anirals. Am. Assoc. Adv. Sci., Washington, DC. (iNSA 14-15558). (Paramecium).

Fiege, H. J. and $\mathrm{k}$. Wichterman. 1959. The protection of radiation-sensitized paramecia from lethal doses of roentgen radiation (abstr.). Anat. Record 133: 276.

Geckler, R. O, and R. F. Kimball, 1953. Effect of x-rays on micronuclear number in paramecium aurelia. science $117(3030)$ : $80-81$.

Giese, A, C., B. McCaw and R. Cornell, 1963. Retardation of division of three ciliates by internittent and continuous ultraviolet radiations at different temperatures. J. Gen. Physiol. 46(5): 1095-1108. (INSA 20-8674). (Faramecium caudatum. Blepharisma japonicum, Colpidium colpoda).

Grayevskiy, Ye, Ya. and A. A. Neyfakh. 1956. Effects of small doses of ionizing radiation on the farameciun caudatum (contribution on the problem of radiostimulation). Doklady Akad. Nauk USSR 111: 1004-1006. (In Russian) (NSA 11-4790).

Grayevskiy, Ye. Ya. and Ye. G. Zinov'yeva. 1958. An investigation of cell radiosensitivity with repeated exposures to ionizing radiation. Doklady Akad. Nauk SSSR (Biol. Sci.) 121(1-6):538-541. (Paramecium).

Grayevskiy, Ye. Ya. and Ye. C. Zinov'yeva, 1958, Fossibility of changes in radiosensitivity of cells under influence of fluorochromes. Doklady Akad. Nauk SSSR 118: 476-478. (In Russian) (Paramecium caudatum). 
Erayevskiy, Ye. Ya. and Ye. G. Zinov'yeva. 1958. The effect of fluorochromes on the sensitivity of cells to radiation. Soviet Phys. (Doklady) 3: 206-208. (Faramecium caudatum).

Grayerskiy, Ye. Ya. and A. I. Shul'mina. 1960. Significance of changes oriçinating in an irradiated aqueous medium during the process of injurine cells by ionizine radiation. Voprosy Tsitologii I Obshchey Fizioloeii. pp. 80-85. (English transl. JHNS-12921). (NSA 16-17438). (Iaramecium caudatum).

Grayevekiy, Ye. Ya., I. V. Nekrasova and A. I. Shul'mina. 1962. Study of the radiation-protective action of cotne protective materials on protozoa. Radiobiolociya 2(1): 148-155. (Énelish transi. AJC-tr-5428). (ISA 16-30309). (Faramecium caudatum).

:alberstaedter, $i$, and A. Back. 1943. Influence of colchicine alone and combined with $x$-rays on Farainecium. Nature 152(3853): 275-276.

Haller, G. 1968. Experimental morphogenesis with the Ciliata: Il. Effects of an UV-irradiation on the differentiation of the cilia in paramecium aurelia. Rev. Suisse Zool. 75: 583-58?. (In French) (NSA $23-33815\rangle$.

Hance, $F, T$, and $A$. Clarce. 1926. Studies on $x$-ray effect. The effect of $x$-rays on the division rate of Earanecium. J. Lxptl. lied. $43(1): 61-70$.

layashi, s. and T. Takayanagi. 1966. Cytological and cytogenetical studies of Earamecium polycaryum. VI. iffects of ramma irradiation especially concerning nuclear division in conjugation. Annot. Zool. Japan 39: 16-22. (NSA 21-18034).

Hildebrand, E. and H. Stieve. 1972. Fermeability of the protozoan cell membrane to water and ions under the action of ultra-violet light. 2 . Naturforsch. 27b(10): 1243-1257. (In German) (NSA 27-5546). (Faramecium, Euplotes, Opalina).

Igarashi, S. 1966. Temperature-sensitive mutation in Iaramecium aurelia. I. Induction and inheritance. i.tutat. Fes. 3: 13-24. (NSA 20-18348). (X-irradiation). 
Igarashi, S. 1966. Temperature-sensitive mutation in Faramecium aurelig. II. Nodification of mutation frequency by pre- and postirradiation conditions. Mutat. Res. 3: 25-33. (NSA 20-18349). (X-irradiation).

kimball, R. F. 1949. The induction of mutations in Faramecium aurelia by beta radiation. Genetics $34(2): 210-222$.

limball, R. F, 1950. The effect of radiations on genetic mechanisms of Paramecium aurelia. J. Cell. Comp. Physiol. 35(SuppI. 1): 157-169.

Kimball, R. F. 1955. The role of oxygen and peroxide in the production of radiation damage in Faramecium. Ann. New York Acad. Sci. 59: 638.647.

Kimball, R. F. 1957. Hodification of the genetic effects of $x$-rays by treatment after irradiation. pp. 252-255. In: Proc. Intern. Genetics Symposium, 1956. Tokyo and Kyoto, September, 1956. Science Council of Japan, Tokyo. (NSA 12-15306). (Earamecium).

Kimball, R. F. 1961. Postirradiation processes in the induction of recessive lethals by ionizine radiation. J. Cell. Comp. Physiol. 58(Suppl. 1i: 163-170. (Earamecium).

Kimball, R. F. 1962. Fractionation of dose and radiation intensity in the induction of recessive lethal mutations oy $x$-rays in Faramecium aurelia (abstr.). p. 6. In: Second Intern. Congress Radiation Fesearch. Silver End Documentary Publications, Ito., London.

Kimball, R. F. 1963. Repair and differential sensitivity to mutation induction: summary and synthesis. pp. 427-441. In: Froc. Symp. on Repair from Cenetic Radiation Damage and Differential Radiosensitivity of Germ Cells. (F. H. Sobels, ed.). Fergamon Fress, NY. (NSA 18-1446). (Paramecium). 
limball, R. F. 1963. The relation of repair differential radiosensitivity in the production of mutations in Faramecium. pp. 167-178. In! Repair from Genetic Radiation. Pergamon Fress, NY. (NSA 17-38854).

Iimball, R. F. 1963. X-ray dose rate and dose fractionation studies on mutation in Paramecium. Genetics $48(4)$ : 581-595. (NSA 17-21515).

i.imball, R. F. 1964. Studies on radiation mutazenesis in microorganisms. pp. 227-234. In: Cenetics Today. Pereamon Press, NY. (NSA 19-21981). (Includes Paramecium aurelia).

rimball, 3.. F. 1964. The distribution of $\mathrm{x}$-ray induced mutations to chromosomal strands in Faramecium aurelia. Hutat. Res. 1: 129-138. (Ni 19-7114).

linball, R. F. 1969. Studies on mutations induced by ultraviolet radiation in Faramecium aurelia with special emphasis on photoreversal. hitat. Res. 8: 79-89. (NSA 23-31709).

rimball, R. F. and N. Galther. 1951. The influence of light upon the action of ultraviolet on Faramecium aurelia. J. Cell. Comp. Physiol. 37(2): $211-233$.

Simball, R. F. and N. Galther. 1952. The role of externally produced hydrogen peroxide in damace to Faramecium aurelia by x-rays. Proc. Soc. Exptl. Biol. Hed. $80(3): 525-529$.

Zimball, P. F, and N. Gaither. 1953. Influence of oxygen upon cenetic and nongenetic effects of ionizing radiation on Parameoium aurelia. Froc. Soc. Exptl. Biol. Bied. 82(3): 471-477.

Jimball, R. F: and J. Z. Hearon. 1955. Tests for a role of $\mathrm{H}_{2} \mathrm{O}_{2}$ in $\mathrm{x}$-ray mutagenesis. I. Istimations of the concentration of $\mathrm{H}_{2} \mathrm{O}_{2}$ inside the nucleus. Radiation Res. 3(3): 283-294. (Paramecium).

r.imball, R. F. and If. Gaither. 1956. Behavior of nuclei at conjugation in Paramecium aurelia. II. The effects of $x$-rays on diploid and haploid clones, with a discussion of dominant lethals. Genetice $41(6)$ : 715-728. (WSA II-845). 
kimball, R. F, and L. Vogt-Kohne, 1962. Effects of radiation on cell and nuclear growth in paramecium aurelia. Exptl. Cell. Res. 28(2), 228-238. (NSA 17-10408).

kimball, R. F. and S.W. Perdue 1962. Studies on the refractory period for the induction of recessive lethal mutation by $x$-rays in Paramecium. Genetics $47(11), 1595-1607$. (NSA $17-7842)$.

Kimball, R. F. and S. W. Perdue. 1967. Comparison of mutagenesis of $x$-rays and triethylene melamine in Faramecium, with emphasis on the role of mitosis. Wutat. Res. 4: 37-50. (NSA 21-16324).

Kimball, R. F., R. P. Geckler and N. Galther. 1952. Division delay by radiation and nitrogen mustard in Faramecium. J. Cell. Comp. Physiol. 40(3): 427-459.

Kimball, R. F., J. Z. Hearon and N. Gaither, 1955. Tests for a role of $\mathrm{H}_{2} \mathrm{O}_{2}$ in $\mathrm{x}$-ray mutagenesis. II. Attampts to induce mutations by peroxide. Radiation Res. 3(4): 435-443. (Paramecium).

Kimball, R. F., N. Gaither and S. M. Wilson. 1957. Fostirradiation modification of mutagenesis in Farameciun by streptomyc1n. Genetics $42(5): 661-669$. (NSA 122698).

Kimball, R. F., N. Caither and S. M. Wilson. 1959. Recovery of stationary-phase paramecia from radiation effects leading to mutation. Proc. Natl. Acad. Sci. (U.S.) $45(6): 833-839$.

Kimball, R. F., N. Gaither and S. M. Wilson. 1959. Keduction of mutation by postirradiation treatment after ultraviolet and various kinds of lonizing radiations. Radiation Res. 10(4): 490-497. (Earamecium).

Kimball, R. F., N. Gaither and S. W. Ferdue. 1961. Wetabolic repair of premutational damage in Parameci.zm. Intern. J. Fadiation Biol, 3: 133-147. (NSA 1: : i3).

Komala, 2. 1968. The observations on the influence a small dose of $x$-rays on the conjugating paramecia. Folia Biol. (Krakow) 16: 299-306. (NSA 23-33819). 
liomala, 2. 1970. Observations on the behaviour of Faramecium jenningsi under the influence of a sublethal dose of x-rays. Folia Biol. (Krakow) 18: 1-8. (NSA 24-51021).

Komala, 2. 1975. Effect of x-rays on strains and syngens of Paramecium aurelia differing in genetic affinity. Folia Bio1. (Krakow) 23(4): 341-423. (NSA 33-2975?).

Kovaleva, N. Ye. 1948. Investigation of the effect of $x$-rays on Paramecium caudatum. Uch. Zap., Leningrad. Gos. Fed. Inst., Kaf, 2001 . Darvinsma. (Yu. U. Folyansky, ed.). 70:75-144. (In Russian).

jovaleva, N. Ye. 1962. Effect of cultivation temperature on sensitivity of infusoria to injurious acti": of $x$-rays. Tsitologiya 4(3): 306. (EnElish tri.i 1 , Federation Froc. 22: T507-513 (liay-June, 1963)). (NSA 17-30318). (Faramecium caudatum).

Kovaleva, N. Ye, 1964. The influence of temperature on the content of cytoplasmic ribonucleic acid in Faramecium caudatum irradiated with $x$-rays. TsitoI0Eiya 6,709-7I7. (In Fussian) (NSA 21-9033).

Kovaleva. N. Ye. 1966. The influence of ionizing radiation on some pathways of metabolic processes in paramecia, Tsitologiya 8: 629-638. (In Russian) (NSA 24365 ).

Kovaleva, N. Ye. and A. V. Yankovskiy. 1965. The effect of ionizing radiation on nuclear reorfanization processes in Earamecium putrinum. I. Nuclear processes in irradiated conjueants. Zh. Obshch. Biol. 26: 176-189. (In Russian) (NEA 20-29007).

hovaleva, N. Ye. and A. V. Yankovskiy. 1966. Nuclear processes at conjugation of paramecia following $x$-ray irradiation. Tsitologiya 8: 80-89. (In kustian) (NSis 20-3304?).

Kovaleva, N. Ye, and G. V. Selivanova. 1966. The influence of temperature variation in the medium on the DNA content of paramecia after ionizing irradiation. pp. 36-45. In. Effects of Ionizing kadiations on Heredity: (N. P. Dubinin, ed.). Ifoscow, Publ. House Acad. Sci. USSR. (In Kussian) (NSA 22-21608). 
Kovaleva, N. Ye, and H. A. Frenkel. 1967. The investigation of the activity of some dehydrogenases in infusoria after $x$-irradiation. Tsitologiya 9: 1550-1558. (In Russian) (NSA 22-36184). (Paramecium caudatum).

Kovaleva, N. Ye. and H. A. Frenkel, 1969. The sensitivity to $x$-irradiation of some dehydrogenases in paramecia adapted to low temperature. Tsitoloeiya 11: 12661274. (In Russian) (NSA 24-7980).

Iitvinova, I. B. 1959. Effects of ionizine radiation on Faramecium cultivation at various temperatures. Doklady Akad. Nauk SSSR 124(2): 448-451. (English transl. pp. 22-24).

Litvinova, I. B. 1959. The effect of postirradiational temperature on the reaction of paramecia produced by different doses of iunizine radiation. Doklady Akad. Nauk SSSR 124(3): 678-680. (English transl. pp. 25-27).

Lozina-Lozinskiy, 1. \%. 1961. The resistance of paramecia adapted to life in warm radioactive springs to different external factors. Tsitologiya $3(2)$ : $154-$ 156 (Fef. $\mathrm{hh}$. (Biol.). 1961: 20D8; BA 38(4): 16469).

liashanskiy, V. F. and K. A. Samoylove. 1964. The effect of ultraviolet radiation on the ultrastructures of the cell. Tsitolofiya 6:59-65. (INSA 18-31241). (Paramecium caudatum).

jole, K. H. 1963. Dose rate and time factor. pp. 1E-33. In: Radiation Effects in Physics, Chemistry and Biology. North-Holland Fubl. Co., Amsterdam. (NSA 17-25019). (On Drosophila eges, mice, birds, Earemecium and silkworm larvae).

likitin, S. A. 1929. Studies on $x$-ray sensitization. II. Chemical sensitization of simple organisms. 2h. Eksper. Biol. Jied. 11: 28-33. (CA 24: 1E76). (Earamecium caudatum). 
Nikitin. S. A. 1929. Studies on $x$-ray sensitization. III. Sensitizing effect of thorium nitrate. $2 \mathrm{~h}$. Eksper. Biol. lifed. 11: 34-40. (CA 24: 1876). (Faramecium caudatum).

Nikitin, S. A. 1930, Roentgen sensitization. II. Chemical sensitization. Strahlentherapie $36: 539-$ 545. (In German) (Includes $x$-ray; Paramecium caudatum).

Ochinskaya, G. K. and I. B. Bychkovskaya. 1965. On the existence of system in the response of biolocical objects to irradiation (Analysis of data obtained on Paramecium caudatum). Doklady akad. Nauk SSSI 160(6): 461-463. (Enelish transl. pp. 4.6). (NSA 19-27997).

Elanel, H.s.J. J. Soleilhavoup and R. Tixador. 1965. Investigations on the action of natural ionizing radiations on the rrowth of one-cell animals. Compt. Rend. 260: 3770-3773. (In French) (NSA 19-27988). (Earamecium caudatum).

Elanel, H., J. F. Soleilhavoup and R. Tixador, 1965. lisise an evidence d'une influence probable des radiations ionisantes naturelles cur la multiplication de Iaranecium caudatum. Compt. Fend. シiol. Sci. 159(4): $988-992$.

Flanel, H., J. P. Soleilhavoup and F. Croute. 1975. Effects of space balloon flikhts on reproductive activity in Farameciun aurelia. pp. 173-180. In: iffe Sciences and Space Fesearch. XIII. AkademieVerlag G.m.b.H., Berlin. (NSA 33-29762).

Planrl, H., A. Bru, J. F. Soleithavoup and R. Tixador. 1967. Effects of low doses of ionizine radiation on multiplication of Earamecium aurelig. Compt. Rend. D264: 2945-2948. (In French) (NSA 22-19435).

Planel, H., J. P. Soleilhavoup, R. Tixador and C. Caratero. 1968. Effect of protection against natural irradiation in Paramecium aurelia after autogany. Compt. Rend. Soc. Biol, 162, 990-995. (In French) (NSA 23-16377). 
Planel, H., R. Tixador, G. Vedrenne and G. Richoilley. 1970. Study of the development of Paramecium

aurelia in an underground laboratory: Influence of natural ionizing radiation. Compt. Rend. Soc. Biol. 164: 654-658. (In French) (NSA 25-13556).

Planel, H., J. P. Solejlhavoup, R. Tixador and C. Caratero. 1971. Detection of a biological response to very weak radiations. pp. 336-339. In: Protection Against Low Energy or Short Range Radiations and the Biological Effects of Radiation. Service Central de Protection Contre les Rayonnements Ionisants, Le Vesinet, France. (In French) (NSA 26-12432). (Paramecium).

Planel, H., J. P. Soleilhavoup, D. Blanc, J. Fontan and $R$. Tixador. 1966. Action du rayonnement du thorium sur la croissance de Paramecium caudatum et de Paramecium aurelia cultives sous dispositif de radioprotection. Compt. Rend. Soc. Biol. 160(5): 1090-1093.

Planel, H., J. P. Soleilhavoup, D. Blanc, J. Fontan and R. Tixador. 1966. Test of experimental demonstration of the biological activity of natural ionizine radiations. Compt. Rend. Ser. D262: 2767-2770. (In French) (NSA 20-43886). (Paramecium caudatum).

Flanel, H., J. P. Soleilhavoup, C. Caratero, R. Tixador and $A$. Caratero. 1968. Influence of radioactivity on the environment in the study of cellular growth. compt. Rend. Soc. Biol. 162: 1215-1219. (In French) (NSA 23-38410). (Paranecium).

Planel, H., J, P. Soleilhavoup, F. Cottin, R. Tixador and G. Kichoilley. 1969. Research on the biological action of natural radiation: study of the erowth of Paramecium aurelia and Paramecium caudatum in subterranean laboratories. Compt. Rend. D269, 16971700. (In French) (NSA 24-12228).

Planel, H., J. P. Soleilhayoup, R. Tixador, P. Croute and G. Richoilley. 1973. Effect of autogamy on cellular sensitivity to natural ionizing radiations and $x$-rays. Final scientific report. I June - 31 October, 1972. Toulouse Univ.. France. $12 \mathrm{pp}$. (AD-761837). (NSA 28-30042). (Paramecium aurelia). 
ropov, A. S. 1961. Influence of urea peroxide on the radiation injuries in infusoria. Radiobiologiya l(5): 676-683. (English transl. AEC-tr-5426). (Paramecium caudatum).

ropov, A. S. 1963. The influence of urea peroxide on the post-irradiation recovery of infusoria. Radiobiologiya 3(1): 121-125. (English transl. AíC-tr5434). (NSA 17-30418). (Faramecium caudatum).

ropov, A. S. 1967. Role of organic peroxides in the initial stafe of radioinduced injury in animals. Radiobiologiya 7(6): 825-830. (English transl. ALC-tr-6891). (NSA 22-51983). (Paramecium).

Fopov, A. 3. and Iu. F. Vinetskiy. 1967. Effect of irradiated glucose solution on phage and infusoria. Radiobiologiya 7(4): 630-631. (English transl. AECtr-6889). (NSA 22-15122). (Paramecium caudatum).

Lowers. E. L. 1948: Death after autogamy in Paramecium aurelia following exposure in solution to the radioactive isotope $\mathrm{P} 32$ and $5 r^{89}, 90, \gamma 90$ (abstr.). Cienetics 33(1): 120-121.

fowers, i. I. 1955. Radiation effects in Paramecium. Ann. New York Acad. Sci. 59:619-637. (NSA 9-3014).

Fowers, E. I. and D. Shefner. 1950. Effects of high dosaces of $x$-rays in Faramecium aurelia. Cenetics 35: 131 .

Koss, A. 1966. Estimation of Erowth patterns of protozoa in radiation experimente. Faper presented at Biometric Soc. Inst. Wathematical statistics, Eastern Regions Joint Weeting, Upton, NY., Apr. 27-29, 1966. Johns Hopkins Univ : Baltimore. 9 pp. (CONF-660441-1). (Gmelin, AED-CONF-66-118-1). (NSA 20-45472). (Paramecium caudatum).

soth, R. 1943. Uber die Kultivierung von Paramecium caudatum, die Veraschune der gezuchteten Klone unde die AbwandlunE des Gesamtaschenbildes unter der Einwirkung von Rontgenstrahlen. Strahlentherapie $74(1)$ : 169-181. 
Sacher, G. A. 1968. Mathematical analysis of the division delay produced by ionizing radiation. Kadiation Res. 33, 644-658. (NSA 22-31240). (Includes Faramecium).

Sacher, G. A., H. L. Powers, D. Shefner and J. li. Gurian. 1962. Effect of $x$-rays on the fission rate of Faramecium aurelia. Argonne Natl. Lab., U. S. Az̈C report TID-15521. 37 pp. (NSA 17-5778).

Saier, F. I. and A. C. Giese. 1966. Action of ultraviolet radiation upon ciliary movement in faramecium. Expt1. Cell kes. 44: 321-331. (NSA 21-11145).

Saier, F. I. and A. C. Giese. 1967. The effect of ultraviolet radiation upon osmoregulation in Faramecium. Photochem. Photobiol. 6: 745-755. (NSA 22-15121).

samoylova, K. A. 1963. Changes in fat and glycozen contents in Paramecium caudatum after UV treatment. Tsitologiya 5, 546-553. (In Russian) (NSA 20-28918).

Samoylova, K. A. 1965. Influence of short-wave UV-irradiation on seneitivity of infusoria to inhibitors of respiration and Elycolysis. Radiobiologiya 5(5): 703-706. (English transl. AEC-tr-6602). (NSA 205386). (Earamecium caudatum).

Samoylova, K. A. and I. F. Ovchinnikova. 1963. The influence of ultraviolet radiation on the nucleic acid content in Paramecium caudatum. I. Sb. Rabot, Inst. Tsitol., Akad. Nauk SSSR (3): 145-15j. (English transl. Oak Ridge National Lab., U. S. Aic report ORNL-tr-1289). (NSA 20-42800).

Samoylova, K. A. and V. A. Krylenkov. 1973. Comparison of the effects of far and near ultraviolet radiation and their photoreactivation on some protozoa. Stud. Biophys. 36-37: 191-203. (NSA 29-778). (Earamecium caudatum. Amoeba proteus).

Schneider, E. 1926. Die biologische Wirkung cer Rontgenstrahlen auf einzellige Lebenwesen nach UntersuchunEen an Faramecium. Strahlentherapie 22: 92-106. 
Schneider, I. 1961. Electron microocope studies of the effect of radiations on the cytoplasm. I. The early effects of $x$-rays on the cytopiasm of Faramecium. Protoplasma 53: 530-553. (In German) (NSA $21-24681$ ).

Schneider. I. 1961. Electron microscope studies of the effect of radiations on the cytoplasm. II. The late effects of $x$-rays on the cytoplasm of paramecium. Protoplasma 53: 554-574. (In German) (NNSA 2I-24680).

ihepard, D. C, 1957. Relation between hydration and ultraviolet radiation sensitivity of Faramecium calkinsi. Dissertation, Stanford Univ., Stanford, CA. (DIss. Abstr. I7(7), 1579).

imirnova, I. B. 1960. The effect of temperature on the response of paramecia to irradiation. Doklady Akad. Nauk SSSR 130(4): 901-903. (English transl. pp. 2830). (NSA 14-14693).

Tixador, K., H. Planel, G, Richoilley and J. H., Jollon. 1969. Generation time is lengthened in Faramecium aurelia cultivated under radioprotection. Compt. Rend. Soc. Biol. 163: 1429-1432. (In French) (NSA 24-51012).

Wichterman, R. 1948. liating types and conjugation of four different races of Faramecium calkinsi and the effects of $x$-rays on the mating reaction (abstr.). Biol. Bull. 95(2): 271-272.

Wichterman, R. 1948. The biological effects of $x$-rays on mating types and conjugation of Paramecium bursaria. Biol. Bull. 94(2): 113-127.

Wichterman, R. 1951. Effects of high dosage irradiation with $x$-rays upon dividing and non-dividing cells and conjugant stages: Paramecium (abstr.). Anat. Record $111(3): 527$.

Wichterman, R, 1951. The effects of $x$-rays upon conjugant and vegetative stages of Paramecium calkinsi (abstr.). Biol. Bull. 101(2): 232-233. 
Wichterman, $R$. 1953. Studies on the effects of $x$-radiation upon Paramecium: variations amone and within species (abstr.). Biol. Bull. 105(2): 387 .

wichterman, $R$. 1953. The Biology of faramecium. HecravHill Book Co., NY. 527 pp.

Wichterman, R. 1954. Paramecia and high dosage radiation. Gesearch Reviews (O.N.R.). Gctober. pp. 7-14.

dichterman, $R$. 1954. Variation in $x$-radiation sensitivity of different stages of growth in Paramecium (abstr.). Biol. Bull. 107(2): 322 .

Nichterman, R. 1955. The usefulness of the one-celled animal, Paramecium, in studying the biological effects of high-dosage x-radiation. Froc. Fenn. Acad. Sci. 29: $78-93$.

Wichterman, R. 1959. Wutation in the protozoan Faramecium multimicron-nucleatum as a result of x-1rradiation. Science 129(3343), 207-208. (NSA 13-4424).

Wichterman, R. 1960. Production of viable races of Paramecium caudatum after micronuclear elimination with $x$-rays (abstr.). Biol. Bull. $119(2): 348$.

Wichterman, R. 1961. Survival and reproduction of Faramecium after $x$-irradiation. J. Frotozool. $8(2)$ : $158-162$.

ilichterman, K. and F. H. J. Figge. 1952. Invironmental factors concerned with the lethality of $x$-rays in Faramecium (abstr.). Biol. Bull. 103(2): 311 .

Wichterman, R. and F. H. J. Figge. 1952. The effects of hematoporphyrin and other substances upon $x$-ray sensitivity of Faramecium (abstr.). Biol. Bull. 103(2): 302 .

Wichterman, R. and F.H. J. Fiege, 1953. The influence of hematoporphyrin, sodium nitrate, and nembutal on radiation sensitivity in Paramecium. Froc. $\mathrm{Am}$. Assoc. Cancer Res. 1: 16. 
Wichterman, R. and F. H. J. Figge. 1954. Lethality and the biclogical effects of $x$-rays in Paramecium: Radiation resistance and 1 ts variability. Biol. Bull. $106(2)$ : 253-263.

Wichterman, R. and F. H. J. FigEe, 1955. Effect of hematoporphyrin on $\mathrm{x}$-radiation sensitivity in Paramecium (abstr.). Science 122(316\%): 468-469.

Nichterman, R. and F. H. J. Figge. 1956. Influence of hematoporphyrin and phenol on x-radiation sensitivity of Paramecium (abstr.). Biol. Bull. 1ll(2): 302-303.

Wichterman, R. and F. H. J. Figge. 1959. The protection of radiation-sensitized paramecia from lethal doses of roenten radiation. Anat. Record 133: 276.

Whehterman, R., H. Solomon and F. H. J. Figge. 1958. The influence of protoporphyrin - nitroresorcinol and other phenols on $x$-radiation sensitivity of Paramecium caudatum (abstr.). Biol. Bull. 115(2): 369-370.

2aar, Ye. I. 1965. Reaction of Paramecium caudatum to the chronic action of small single and fractional doses of ultraviolet radiation. Radiobiologiya 5(2): 169-173. (EnElish transl. AEC-tr-6599). (NSA 19-26016).

Zinov'yeva, Ye. G. 1958. Causes of death in infusorians under the influence of x-rays. Doklady Akad. Nauk SSSR 121: 80-83. (English transl. pp; 521-526). (NSA 12-16880). (Paramecium caudatum).

Zinov'yeva, Ye. G. 1958. Dependence of the survival of Paramecium caudatum on their number in unit volume on irradiation by $x$-rays. Doklady Akad. Nauk SSSR 118: 694-697. (English transl. pp. 209-212). (NSA 12-9585; 13-4426).

Zinov'yeva, Ye. G. 1962. Paramecium injury caused by the radiolytic products of water at the moment of radiation interaction. Doklady Akad. Nauk SSSR 145(6): 1389-1392. (English trans1. pp. 722-724). (NSA 17-52). 
zinov'yeva, Ye. G. 1966. Investigation of the radioreeistance of Faramecium caudatum durine nuclear regeneration. pp. 28-35. In: Effect of Ionizine Radiation on Heredity. (N. F. Dubinin, ed.). Mloscow, Pubi. House Acad. Sci. USSR. (In Russian) (NSEA 2221606).

(Spathidium)

Williams, D. B. 1958. Effects of $x$-rays on fission in the predaceous Holotrich, ipathidium spathula. J. Protozool. 5(Suppl.): 25 .

Williams, D. B. 1962. Sensitivity of Spathidium spathula to low doses of $x$-radiation. J. Protozool. 9(2): 119 122. (NSA 16-21954).

Williams, D. B. 1966. Effects of $x$-rays on cell lethality and micronuclear number in the ciliate Epathidium spathula. J. Protogool. 13:272-277. TNEA 21-8977).

Williams, D. B. 1968. Iffects of radiation, antibiotics and alkylating agents on cell diviaion and Erowth in the ciliate Spathidium spathula. J. Irotozool. 15(4): 811-816. (NSA 23-38755).

(stentor)

Burchill, 3. R. 1968. Effecte of radiation on oral reEeneration in Stentor coeruleus; S. ixptl. Zool.

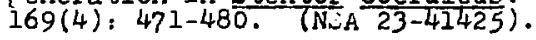

Burchill, B. R. and K. C. Rustad. 1969. Ultravioletmicrobeam irradiation of regenerating stentor. J . Frotoz001. 16(2): 303-306. (iNA 23-48191).

Himball, $F . F .1958$. Experiments wi th stentor coeruleus on the nature of the radiation-induced delay in fission in ciliates. J. Frotozool. 5(2): 151-155.

Freece, A. W. 1969. Camma irradiation of stentor polymorphus. J. Frotozool. 16: 289-294. (NSA 23-48190). 
(Tetrahymena)

Calkins, J. C. 1963. Detailed study of the lethal effects of $x$-rays and ultraviolet light on two ciliate protozoans. Thesis, Univ. of Texas, Austin. $139 \mathrm{pp}$. (NsA 20-36661). (Paramecium aurelia. Petrahymena pyriformis).

Calkins, J. 1967. Similarities in the radiation response of Escherichia coli and Tetrahymena pyriformis. Intern. J. Radiat. Biol. 13: 283-288.

Calkins, J. and G. Griges. 1969. U.V. reactivation of protozoa. Fhotochem. Fhotobiol. 10: 61-66. (NSA 24-7983). (Tetrahymena pxriformis).

irnet, S, G., E. C. Rustad and N. I. Oleinick. 1975. Radiation-induced inhibition of RNA synthesis in Tetrahymena pyriformis. Intern. J. Padiat. Biol. 28(1): 67-74.

Fa:upathy, K., I. S. Netrawali and D. S. Pradhan. 1975. Oxidative phosphorylation by ietrahymena pvriformis mitochondría exposed to Eamma radiation in vivo and in vitro. Intern. J. Radiat. Biol. 28(6): 593-597.

Fasupathy, K., If. S. Netrawali, D. S. Fradhan and A. ireenivasan. 1976. Repair of radiation-induced strand scissons in nuclear and mitochondrial DNA's in ietrahymena pyriformis. Radiation Res. 66(1): $147-157$.

Paul, I. J. and A. H. Zimmerman. 1975. RNA synthesis and polyribosome metabolism in $x$-irradiated synchronized Tetrahvmena. Fadiation Res. 61(1): 144157 .

Roth, J.S. and G. Buccino. 1965. Biochemical studies on irradiated protozoa. III. Catalase activity in Tetrahymena pyriformis $\mathrm{l}$. J. Protozo01. $12(3)$ 432438. (NSA 20-22598).

Schmid, P. 1967. Effect of $x$-radiation on the erowth and division process of Tetrahymena pyriformis. Biochem. Biophys. Res. Commun. 26: 615-620. TNSA 21-18025). 
Stephens, R. E., I. J. Paul and A. Ji. 2immerman. 1976. RNA precursor pool metabolism and RNA synthesis in $x$-irradiated Tetrahymena. Intern. J. Radiat. Biol. $30(1): 83-89$.

Vijver, G. van de. 1967. Studies on the metabolism of Tetrahymena pyiformis GI. III. Effects of $\gamma$-irradiation on the respiratory rate. Enzymologia 33: $331-344$.

Yatvin, M. B., C. K. Kintner and C. i. Elson. 1976. Polyribosomes and protein synthesis. A paradoxical effect of oxygen in -irradiated Tetrahymena pyriformis. Intern. J. Radiat. Biol. 29(6): 589-593.

(Others)

Ammermann, D. 1971. Morphology and development of the macronuclei of the ciliates Stylonvchia mytilue and Euplotes aediculatus. Chromosoma 33(2): $209-238$. (NSA 25-58096). (X-rays; autoradiographic experiments).

Bacq, Z. Hi. 1952. Effect of $x$-rays, cyanide, and various radiation protective agents on the infusoria. Acta Radiol. 38: 489-505. (In French) (NSA 7-2968). (4 species of Ophryoglenidae).

Balcerzak, C. 1971. Influence of water radiolysis products on the mortality of the protozoa Spirostomum ambiguum. Ann. Acad. Hes. Lodzenis 12: 7-18. (In Folish) (NSA 30-9939). (Irradiated water molecule).

Bridgman, A. J, and R. F. Kimball, 1954, The effect of $x$-rays on division rate and survival in Tillina masna and Colpoda $\mathrm{sp}$. with an account of delayed death. J. Cell. Comp. Physiol. 44(3): 431-445.

Brideman, J. and C. Kine. 1962. A study of the effects of repeated irradiation on the cysts of a ciliate, Tillina maena. Radiation Res. 17(2): 203-208. (NSA $16-26827)$.

Ducoff, H. S. 1957. Factors affecting radiation-induced division delay in Chilomonas paramecium. Physiol. Zool. $30(3): 268-280$. (NSA $11-11861)$. 
Ducoff, H. S. and B. D. Butler. 1965. Photoreactivation of ultraviolet-induced suppression of division in Chilomonas paramecium. Exptl. Cell. Res. 40(1): 104111. (NSA 20-6823).

Hildebrand, E. and H. Stieve. 1972. Fermeability of the protozoan cell membrane to water and ions under the action of ultra-violet light. $z$. Naturforsch. 27b(10): 1243-1257. (In German) (NSA 27-5546). (Faramecium, Évplotes, Opalina).

Fodson, S. A. 1968. Comparative responses of two protozoa to two types of radiation. Experientia 24 (1): 59 . (iN\$A 22-21619). (Actinophrys sol, Actinosphaerium nucleofilum).

Hunter, N. W. 1965. Effect of different pH levels on the activity of the phosphomonoesterases of Stylonychia pustulata following ultraviolet irradiation. Fhysiol. 3001. 38(4): 343-348. (INSA 20-5272).

Kasturi Bai, A. K. and [.. E. lianjula. 1974. Effects of tritiated water on the division rate of Spirostomum ambieuum minor. Stimul. News 1. (6): 34-41. (NSA 32-28223).

Schaudinn, F. 1899. Ueber den kinfluss der Rontgenstrahlen auf Protozoen. Pflugers Arch. Ees. Physiol. $77(1 / 2)$ เ 29-43. (20 epecies).

Shepard, D. C., A. C. Giese and C. I. Brandt. 1956. Action of $x$-rays on Didinium nasutum. Radiation Res. 4(2): $154-157$. (NiA $10-5459)$.

(Wiscellaneous)

Bonham, K., A. H. Eeymour, L. K. Donaldson and A. D. Welander. 1947. Lethal effect of $x$-rays on marine microplankton oreanisms. Science 106(2750): 245-246. (Reviews literature on bacteria, yeasts and Frotista).

Kamshilov, M. W. 1963. The influence of ultraviolet light on microbiocoenoses of marine protozoa. Doklady Akad. Nauk SSSR (Biol. Sci.) 150(6): 1363-1365. (English transl. pp. 671-673). (Plectonema notatum, diatoms, flagellates, amoebae, ciliates, bacteria, yeast-like cells, Chlorella). 
Kimball, R. F. 1957. Nongenetic effects of radiation on microorganisms. Ann. Rev. Hicrobiol. 11: 199-220. (NSA 12-4663). (Fungi, bacteria, protozoa).

tharton, D. R. A. 1957. Action of ionizing radiations on protozoa. pp. 225-234. In: Radiation Preservation of Foods. (S. D. Bailey et al.. eds.). U. S. Army Research and Development Series No. 1 .

Wichterman, $R$. 1957. Biological effects of radiations on protozoa. Bios 28: 3-20.

Nichterman, R. 1972. Biological effects of ionizing radiations on protozoa: Some discoveries and unsolved problems. Bioscience 22(5): 281-289.

\section{Coelenterata}

(Hydra)

Barbarin, V. V. and V. A. Kostromskaya. 1963. Qualitative changes in oxidation-reduction processes during Eamma irradiation. Sb. Tr. Sverdlovsk. Gos. Wed. Inst. 39: 11-18. (NSA 19-8912). (Hydra).

Bhattacherya, S. 1971. Effect of $x$-rays on the rereneration of the oral structures of Hydra vulgaris. I. Effect of $x$-rays on the rate of regeneration. 2 . Biol. 116(6): $480-486$. (NSA 26-23139).

Bhattacherya, S. 1971. Effect of $x$-rays on the regeneration of the oral structures of Hydra vulgaris. II. Role of interstitial cells in the process of receneration. 2. Biol. $116(6)$ ) 487-493. (NSA 26-23138).

Bhattacherya, is. 1971. Effect of x-rays on the regeneration of the oral structures of Hydra vulgaris. III. Contribution of endoderm cells in wound healing and hypostome differentiation. Z. Biol. 116(6): 493-501. (NSA 26-23140).

Bhattacherya, S. 1972. Cell interaction during regenerati on of normal and radiated hydras. Indian J. Exptl. Biol. 10(1): 8-12. (NivA 26-43367). 
Brien, F. and J. P. van den Eeckhoudt. 1953. Bourgeonnement et receneration chez les hydres irradies par les rayons $x$. Compt. Rend. 237 (14): 756-758. (NSA 8-51).

Daniel, G. L. and H. D. Fark. 1951. The effect of x-ray treated media on hydra tentacles. J. Cell. Comp. Fhysiol. $38(3): 417-426$.

Daniel, G. E. and H. D. Park. 1953. Glutathione and $x$-ray injury in hydra and paramecium. J. Cell. Comp. Fhysiol. $42(3)$ : $359-367$.

“itra, J. 1969. Relative radio-sensitivity of different cell-types in hydra. Gegenbaurs Horphol. Jahrb. 114: 258-268. (NSA 25-42613).

i.itra, J. 1970. Differential $x$-ray sensitivity of hydras in relation to age. Indian J. Exptl. Biol. 8: 302303. (NEA 25-39906).

liookerjee, A. 1968. Extraction and x-ray denaturation studies of sponge and hydra DNA. Sci. Cult. (India) 34: 105-108. (NSA 22-51407).

l.ookerjee, S. and A. Aditya. 1966. Re oneration time in irradiated hydras. Indian J. Expt.L. Biol. 4: 201205. (iNSA 21-20368).

Noda, $K$. and N. sgami. 1975. Regenerati un of transplanted intact cell populations in lethally irradiated hydra. Radiation Res. 63(1): 174-184. (NSA 33-7567). (Felmatohyaira robusta).

Fark, H. D. 1958. Sensitivity of hydra tissues to $x$-rays. Fhysiol. 2001. 31(3): 188-193.

Fodder, N. G., A. IHookerjee, N. N. Saha and R. Falit. 1970. Iffect of $x$-irradiation on hydra in the presence of arginine and citrulline and study of the radiolytic products. Indian J. Exptl. Biol, 8: 3738. (NEA 25-2588). 


\section{(Planaria)}

Anonymous. No date. Biological and psychological effects of radiation in the planarian. Univ. of Michigan, Tech. Report No. 1 , U. S. AEC report TID-18949. 22 pp. (NSA 17-28679).

Asakura, K., Y. Kishida and $\mathrm{T}$. Kido. 1969. Effect of $x$-irradiation on the regeneration of the planarian, Dugesia japonica. Scient. Rept. Kanazawa Univ. (Japan) 14:253-261. (ISA 24-46649).

Benazi, bi. 1962. The effect of lonizing radiation on the development of Plangrla. Atti. Accad. Nazl. Lince1. Rend.. Classe Sci. Fis.. Hat Nat. 32, 26-29. (inglish trans 1. UCRI-Trans-10276). (NSA 17-5789; 23-5011).

Benaza1, H. 1962. The action of irradiated sperm in normal fecundation and in peeudoeramia in planaria. Atti, Accad. Nazl. Incei. Rend.. Classe Sc1. Flo. liat. Nat. 32(8), 286-289. (In Italian) (NSA 1717810).

Bordeen, C. R. and F. H. Baetjer. 1904. The inhibitive action of the roenteen rays on regeneration in planarlans. J. Exptl, 2001. 1(1), 191-195.

Brown, F. A., Jr. 1963. An orientational response to weak camna rediation. Biol. Bull. 125(2), 206-225. (NSA 18-11673). (Planaria).

Brown, F. A., Jr, and Y. H. Park. 1964. Seasonal variations in olen and strength of gamma-taxis in planar1ans. Nature 202(4931): 469-471. (I37Cs source).

Brown, F. A., Jr., H. H. Webb and L. G. Johnson. 1962. Orientational responses in organisms ffected by very small alteratione in eamma (Cs 37 ) radiation (abstr.). Blol. Bull. 123(2):488-489. (Planaria).

Chandebois, R. 1965. Variation of the regenerating. capacity of 1rradiated planaria (Dugesis gubtentaculate as a function of the $x$-ray dose. compt. Rend. 260. 4834-4837. (In Freneh) (NSA 19-40366). 
Chandebois, R. 1968. The respective roles of mitotic activity and of cell differentiation in planarian regeneration. J. Embryol. Exptl. Niorphol. 20(2): 175-188. (NSA 23-20160). (X-ray).

Chandebois, R. 1971. Increase of regeneration power in planaria irradiated to lethal doses by stimulation of the type I cell system. Compt. Fend. D272(10): 1417-1419. (In Pranoh) (NSA 25-44890).

Corbridge, A. 1967. Planaria: How they are affected by direct radiation and by irradiated food. Ann. J. Colorado Dent. AEsoc. 45: 22-25. (NSA 24-6107).

haslauer, J. 1964. The effects of visible and ultraviolet light on the regenerative growth of planarian. Strahlentherapie 125: 604-630. (In German) (NSA 19-8922).

Hori, I, 1979. Regeneration of the epidermis and basement membrane of the planarian pugesia japonica after total-body x-irradiation. Radiation Res. 77(3): 521-533.

liendall, K. and D. S. Nachtwey, 1968. Inhibition of regeneration of planaria by midlethal exposures to $x$-rays. U. S. Naval Radiological Defense Lab., San Francisco, report USNRDI-TR-68-29, 24 pp. (AD-668330). (NSA 23-16374).

Lefuarda-Figueras, A. 1969, Effect of $x$, Eamma, and UV radiations on populations of Dugesin dorotocephala (Platyhelminthes: Turbellaria) under action of the serotonin-sulfate complex of creatinine. Thesis, Univ. Nac. Autonome de Mexico, Niexico City, D. F. $98 \mathrm{pp}$. (In Spanish) (NSA 24-39519).

Laquarda-Figueras, A, and h. Villalobos-Pietrini. 1967. Frotection by orotonin-creatinine sulfate complex of the planaria Dugeris tifring against the lethal effects of $x$-rays. Proc. Soc. Exptl. Blol. wied. 126, 667-669. (NSA 22-23597).

Lange, C. S. 1968. An outline of studies on the cellular besis of planarian radiation lethality. J. Fhysiol. 197: 54F-55F. (NSA 23-2913). (Dufesie lugubris). 
Lange, C. S. 1968. Studies on the cellular basis of radiation lethality. I. The pattern of mortality in the whole-body irradiated planarian (Tricladida, Paludicola). Intern. J, Radiat. Biol. 13(6): 511530. (NSA 22-49517). (Dugesia spp., Polycelis tenuis).

Lange, C. S. 1968. Studies on the cellular basis of radiation lethality. II. Survival-curve parameters for standardized planarian-populations. Intern. J. Radiat. Biol. 14(2): 119-132. (NSA 23-20331).

Lange, C. S. 1969. Studies on the cellular basis of radiation lethality. $V$. A survival curve for the reproductive integrity of the planarian neoblast and the effect of polyploidy on the radiation response. Intern. J. Radiat; Biol. 15(1), 51-64. (NSA 23-22360). (Dugesia lueubris).

Lange, C. $s$. and C. W. Gilbert. 1968. Studies on the cellular basis of radiation lethality. III. The measurement of 5 tem-cell repopulation probability. Intern. J. Radiat. Biol, 14(4), 373-388. (NSA-23 33817). (Dueesia lupubris).

Le lioigne, A. 1965. Effects of irradiations with x-rays on the embryonic development and the regeneration capacity for hatchine of Polycelis nifra (Turbellarie, Triclade). Compt. Rend. 260: 4627-4629. (In French) (NSA 19-31826).

Le Hoigne. A. 1966. Study of embryonic development and regeneration in the embryo of the planarian Folycelis niera (turbellarian, tricladidan). J. Embryol. IxptI. Horphol. 15: 39-60. (In French) (NSA 21-28648).

Ie lifoifne, A. 1968. Electron microscopic study of the development of $x$-irradiated embryonic planarian structures. J. Jmbryol. Exptl. Wiorphol. 19: 181192. (In French) (NSA 22-40928).

WicConnell, J. V., M. I. Clay and R. B. Kauffman. 1961. Evaluation of $2 D 50$ level in decapitated Planaria. Univ. of Michiean, U. S. AiC report TID-15984. 7 pp. (NSA $16-23414$ ).

Kieserve, F. G. and H. J. Kenney. 1934. The effects of $x$-rays on Planaria dorotocephala. Science $79(2053)$ : $408-409$. 
Folikarpov, G. G. 1957. Features of the reactions of radiation aftereffect in Felmatohydra olifactis. pp. 34-35. In: Biochemical and Fhysico-chemical Baris of Fadiation Iffects (February 23-28, 1957). (abstracts of reports). Noscow State Univ. (In Fussian).

5olikarpov, G. G. 195?. The development of radiation after-effects. Biofizika $2(2): 174-177$. (English transl. pp. 176-179. (NiA 12: 2641). (Gelmatohydra olieactis .

valive, H. T. and li. I. Clay. 1964. Froject glowworm rides aqain. Jorm Kunner': DiE. 6: 78-81. (NSA 18-31249). (rlanaria).

-chaper, A. 1904. ixperimentel.le Untersuchungen uber den Linfluss der kadium-strahlen und der kadiumemanation alif embryonale und regenerative intwicklungeborgan! $\epsilon$. Anat. Anz. 25(12/13): 298-314; 25(14/15): 326-337. (In German) (Bana esculenta, Eana fusca, triton, planaria).

Sengel, C. 1959. Is the caudal region of planarian capable of inducinf the regeneration of a pharynx? J. imbryol. ixptl. borphol. 7(1): 73-85. (In French) $(x-\mathrm{ray})$.

ienger, C. l.. 1964. Effect of $x$-ray irradietion on oxyfen uptake by planarians, Worm kunner's Dif. 6: 46-51. (1iis $18-31248)$.

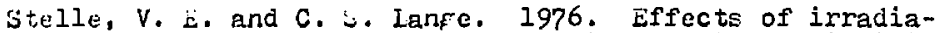
tion on stem cell response to differentiation inhibitors in the planarian Dugesia etrusca. Radiation Fes. 6? (1.): $21-29$.

"'ehirofi, $i$. 1963. Fusion of different body seEsents usinf $x$-ray-irradiatod animalr and non-irradiated ones in a freshwater planarian, Bdellocephala brunnea. Sci. Kept., rac. Iit. Sci, Hirosaki Univ. 10(1). (NSA 13-31232).

.jolff, L. and si. Lender. 1962. The neoblast and phenoinena of jnduction and inhibition in refeneration of planaria. Annee Biol. 38, 499-529. (In French) $(N i A) 18-29263)$. 


\section{Rotifera}

Failla, F. hi. 1959. Some effects of radiation on rotifere and their unirradiated profeny (abstr.). Radiation Res. 11(3): 442 .

Failla, P. IV. 1962. iffects of radiation on rutifers irradiated at different afes. pp. 52-57. In: Radiolofical Fhysics Division Semiannual seport, Ju1y - December, 1961. ArFonne latl. Lab., U. $\therefore$. AEC report ANI-6474. (HEA $16-30184$ ).

Yockey, H, F. 1958. A etudy of aeine, thermal killine, and radiation damafe by information theory. pp. 297316. In, Symposium on Information Theory in Diolory, Catlinbure, Tenn., October 29-31, 1956. J'ereanion Prese, Iondon, Linfland. (Involves jeast, insectr, rotifers).

\section{Hollusca}

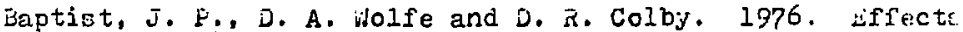
of chronic Eamma radiations on the growth and curvival of juvenile clams (Liercenaria mercenaria) and scallop:s (Arropecten irradians). Health Fhys. 30(1): 79-83.

Bogomoletz, V. I. and V. A. Waiskiy. 1966. Charige in the. biophysical parameters of the surface layer of the protoplasm of mollusk neurons under the effect of ionizing radiation. Fiziol. $2 \mathrm{~h}$., Akad. Nauk Lkr. Wi: 12, 63-69. (In Ukrainian) (NSA 20-22591).

Bonham, $Y_{2}$. 1949. Effects of $x$-rays upon the firesh-whter snail, Kadix japonica. Univ, of Washineton, U. S. AEC report AECU-309; UNFI-21. 31 pp. (NiA 3-505).

Borhan, l. 1955. Siensitivity to $x$-rays of the early clenvage stages of the snail llelisoma subcrenatuli. Growth 19(1), 9-18. (NEA 9-5845).

zonhan, l., and $\because$. F. halumbo. 19jl. iffects of $x$-raje cn snails, crustacea, and alewe. Growth 15(3): 155-1EE. (ikdix japonica, Thais Iomejlosa, anphipod, Artemic salina, Chlorelia, Ankistrodesmus, Chroococcus, synechococcus). 
Born, $d$. 1960. Release of reflexes in snails by $x$ and a.Lpha rays. itrahlentherapie $112: 634-636$. (I Cerman) (INSA 14t-22791).

Srown, F. A., Jr, and H. Hebb. 1968. Some temporal and reofraphic relations of snail response to very weak ranma radiation. Fhysiol. Z001. 4l(4): $385-$ Ho0. (NA 23-22361). (ivessarius obsoletus).

srown, F. A., Ir., F. i.: Sebb and $\therefore$. F. Eennet. 1950. Conparisons of some fluctuatione in cosmic rediation and in orfaniemic activity durine 1954, 1955 and 1956. im. J. Hysiol. 195(1): 237-243. (Includes lica sienar, Triturus, Fucue, quahog).

Cither, 3 . it. 3959. The effects of $x$-radiation on the early cleavope stares of the snail. Ilyanassa obso1etil. Fadiation lies. 11(5); 720-731. (Nis 14-1393).

A.i. j. A. and r. Boeller. 1968. X-radiation of unconelania formosena, cnail host of ichistosoma jeporicun: iffect on reproductivity and mortalit $t^{\prime}$. $\mathrm{m}$. i. Frop. ㅅet. IIVE, 17: 900-903. (NSA 23-29724).

Coojey, J. I. 1970. juffects of chronic irradiation and texperature on populations of the aquatic snail yitsa heterostropha. Thesis, Univ. of tennessee, inoxville. ix, 67 pp. (Also: Cooley, J. I. and j. J. Helson, Oalk Fidec Nat. Lab., U. U. AlC report OUit-4612). (WSA 25-26915).

Coojey, J. i. 1973. Sffects of chronic enviromental radiation on a natural population of the aquatic Enail Fhysa heterostropha. Radiation nes. 54(1), 130-140. (isisa 28-6071).

Gostey, I. 1. 1973. Lffects of temperature and chronic irradiation on populations of the aquatic snail Ihysa heterostrouha. pp. 585-590. In: :adionuclides in icosyeteme. (D. J. Helson, ca.). U. $s . A i c$ report CCNO-710501-FI. (NSA 28-27634).

cooleg, J. L. and F. L. filler, Jr. 197l. Liffects of chronic irradiation on laboratory populations of the aquatic snail Fhysa heterostropha. Siadiation res. 47(3): 716-724. (N)A 25-55314). 
Ganelis, S. A. 1973. itudy of rnciosensitivity of naturnl populntions of freshwater molluck Iemnaca rtarnalis 1. pp. 89-94. In: tadioccolocy of dater oreanisms. III. The Effect of Ionizini Tiadiation on water Orranism: (G. F. Andruchitie. e..). Ri, Ia, Iatel'stvo zinatne. (wn lish transi. AiC-tr-7592). (NSA 30-24360; 31-11651).

Panelis, S. A. 1975. Radiosensitivity of enbryos of Iymnaca etarnalis 1. from two natural popl:1:at.jo:er. Ekologiyg 6(2): $84-86$. (sin lish tuank1. pp. 150 153). (INSA 33-29758).

lanelis,, A. and 1. I. Il'in. 197?. radiosentitivit of comon pond snail embryos from two icolated natudis populations inhabitine different ecolor ical conditioni . pp. 167-163. In: Radioecolo y of inimals. (i..... Mleksaklin, ed.). "ivuka," toscow. ( $f_{n}$ nuksi:in).

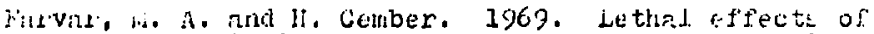
Fuma radiation on the schis tos onte larva carricl snail (ilustralorbie labratuii). An. J. lubl. lilt!.. 59: $2077-2160 .\left(\right.$ Mis $\left.^{2} 24-17125\right)$.

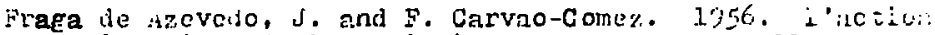
biolofique de la radiation faruma sur der mol! se rue! d'enu rouce. sull. Soc. Fath. ixotique $42(5)$ : 217 . ?21.

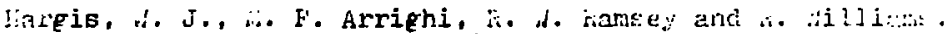
1057. Some effects of hifh-frequency $x$-rays or tire oyster drill, Uroealpinx cinerca. Froc. Hat. .hell. firh. dicsoc. 47: 68-72.

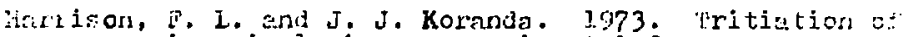
aquatic animals in an experimental freshwe $\tau \in \dot{k}$ nool. pp. 425-43/4. Ins tadionuclides in tcover telli.

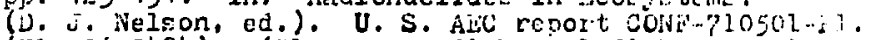

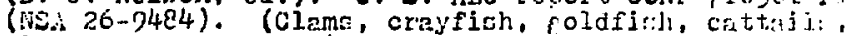
Ithophora, Plankton).

listann. 11. 197l. Carbonate crye tals and screloprotelis

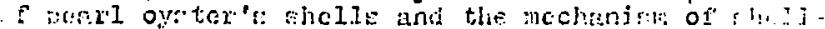

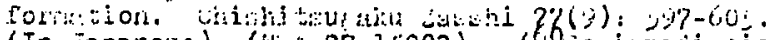

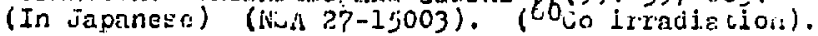


Horiguchi, Y. and T. 'Isujii. 1967. Studies on the production of black pearls by irradiation with radioactive rays. III. Relationship between the coloration obtained by -ray irradiation and the manganese contents in the shelle of several shellfishes. Nippon suisan Cakkaishi 33, 5-11. (N'A 22-10855).

HuF, 0. I. 1958. The release of the feeler reflex in snails by $x$ and alpha radiation. strahlentherapie 106: 155-160. (In German) (NEA 12-11256).

Joosse, J., J.. H. Boer and C. J. Cornelisse. 1968. Gametogenesis and oviposition in Lymnaea stagnalis as influenced by gamma-irradiation and hunger. Symp. zool. soc. Lond. 22: 213-235.

Kulikov, N, V.. N, A. Timofeyeva and S. A. Lyubimova. 1966. Influence of iorizine radiations on the early ctaces of development of i.fmnaea staenalis I. Radiobioloriya 6(6): 908-912. Tinglish transl. NëC-tr6775). (NSA 21-36717).

Luwahara, $\vec{x}$. 1973. Effect of radionurlides on floating larva of Crassostrea echinata. pp. 18-21. Investication of the Effecte of low Concentrations of Redionuclides on Aquatic Life. liuclear Safety iesearch Assoc., Pokyo. (In Japanese) (NEA 31-8958).

Iu, C., T. Hu, C. Ch'en Y. Li and T. FanE. 1964. Effect of lare e doses of 60Co-radiation on the cametes of Laninaria angustata. Chune iuo Hal Yang Hu Chao Heueh Jui 1963 Nien ksueh Shu Nien Hui Lun Wen Chai Yao Hui Plen. Feking. p. 94. (In Chinese) (INSA 21-9032).

bix, ii. C. 1970. Histopathological effects of ionizine radiation on the lacific oyster, Erassostrea fieas. An examination of defenerative syndromes, cellular reparative mechanisms, and their relation to normal cell renewal. ejstems. Thesis : Univ. of Washington, :eattle. $183 \mathrm{pp}$ (Univ. isicrofilins Crder No. 7lE515). (NijA 25-42607).

i.ix, l.. C. 1972. Chronic tissue dereneration in the lacific oyster: Crassostrea rifas. following acute f-irradiation. kadiation Ree. 49(i): 176-189. (NSA 26-23141). 
Mix, h. C. and A. K. Spariss. 1971. Repair of digestive tubule tissue on the Facific oyster, Crassastrea eicas, damae ed by ionizine radiation. J. Invertebr. Fathol. 17(2): 172-177. (NEA 26-43361).

Nelion, V. A. 1968. vffects of strontium-90 - yttrium-90, zinc-65, and chromium-51 on the larvae of the Facific oyster, Crassostrea eifas. Thesis, Univ. of Washington, seattle.

Neleon, V. A. 1972. Effects of ionizing radiation and temperature on the larvae of the Pacific oyster, Crassostrea Eieas. Thesis, Univ. of vashinfton, Seattle. 88 pp. (NSA 26-48276).

Welson, V. $\therefore$. 1972. iffects of strontium-90+yttriun-90, zinc -65 , and chromium-51 on the larvae of the Facific oyster Crassostrea eieas. pp. 819-832. In: 'i'he Columbia kiver Istuary and Adjacent Ccean waters: Bioenvironmental studies. (A.T. Fruter and D. $i$. Alverson, eds.). Univ. of Jashineton fress, ieattle, ilA.

ielson, V. A. 1973. Lffects of ionizine radiation and temperature on the larvae of the Pacific oyster, Crassostrea eifas. pp. 591-598. In: kadionuclides in icosystems. (D. J. Nelson, ed.). U. Z. A.C report CONF-710501-F1. (NSA 25-37861).

iatrusheva, O. I. and I. A. Tarchevskiy. 1965. Q -irradiation influence of frequency of systoles in mollusk embryo. Radioblologiya 5(2): 314. (inelish transil. AOC-tr-6599). (NEn 19-26025).

Eerlowapora-czumlewicz. A. 1964. Iffect of ionizing radiation on the population kinetics of the snail Australorbis Elabratus: AEe at exposure and the effects on reproduction. Padiation kes. 23(3): 392-404. (BEA 19-2139).

ferlowarura-izunlewica, A. 1964. iffects of radiation on the population linetics of the snail qustralorbit labratus: Afe at exnosure and immediate and late effocts of x-rays. iadiation fies. $23(3)$; $377-391$. (iWA 19-2138). 
Perlowagora-Szumlewicz, A. P. 1964, Schistosomiasis: Age of snails and susceptibility to $x$-irradiation. Science $144(3616), 302-303$. (NSA 18-19698).

Ferlowagora-Szumlewicz, A. 1964. Survival, Erowth, and fecundity of Australorbis labratus snails deveioped from eegs exposed to ionizing radiation. Exptl. Farasitol. 15(3): 232-241. (NSA 18-38836).

Ferlowacora-Szumlewicz, A. and E. G. Berry. 1964. iffects of icnizine radiation on uustralorbis glabratus eggs. ixpti. Farasitol. 15(3): 22S-23I. (ifis 18-38835i.

Perlowagora-szumlewicz, A., I. G. Berry and H. I. Andrews. 1962. iffects of lonizine radiation on the snail, Australorbis glabratus, an immediate host of schistosoma mansoni (abstr.). p. 200. In! Second Intern. Coneress kadiation Research. Silver End Documentary Fublicatione, Itd., Iondon.

Fetri, V. N. (ed.). 1970. Effects of lonizing radiation on hydrobionts and land plants. Ir. Inst. Ekol. kast. zhivot. (74), 1-98. (In Russian) (NSA 25-24462). (Esox lucius, Tunica tunica, Ivmnaeg stamalis, alfae).

Freston, A., i : h. Dutton and B. R. Harvey, 1968. Detection, estimation and radiological significance of silver-110m in oysters in the Irish Sea and the Black-ilater Estuary. Nature $218(5142)$ : 689-690.

Frice, T. J. 1965. Accumulation of radionuclides and the effects of radiation on molluscs. pp. 202-210. In: Biological Froblems in water Follution. (C. i.. Tarzwell, ed.). U. S. Fis, R. A. Taft Sanitary Hngineerine Center, Cincinnati, OH. Fublic Health Service Fubl. Wo. 999-itF-25.

Funt, A., F. Nijhof-Pombach and B. Schippers. 1957. Auscle contracture elicted by ultraviolet irradiation. Acta Fhysiol. Fharnacol. Neerland 6 ; 551-555. (iisytilus eduIis, frog). 
Bavera, C. 1966. Effects of $x$-irradiation on various stafes of the life cycle of Fhysa ecuta Draparnalud, a fresh-water gactropod. pp.799-808. In: Jisposel of Radioactive Wastes into Seas, Cceans and Surface lyaters. Intern. Atomic inerey AEency, Vienna, Austria, pubIlcation $\equiv I I /$ FUB $/ 126$. (NSA 20-40700).

Favera, 0 . 1966. The effect of $x$-rays on demographic characteristics of a freshwater Eastropod, Fhysa acuta Drap. Walacologia 5: 51 . (MEA 21-34747).

ilavera, 0.1967 . The effect of $x$-rays on the demoEraphic characteristics of Fhysa acuta (Gastropoda: Basotumatophora). Wialacologia 5: 95-109. (NSA 226885).

Ravera, 0. and G. liariani. 1966. Fecundity, fertili.ty and recovery of eerminal tissue of jhysa acuta exposed to acute doses of $x$-rays. Atti. Accad. Nazl. incei. Rend., Classe ci. rie liat. Nat. 41: 380-385. (In Italian) (INEA 21-32763).

Ravera, $\mathrm{C}$. and $\mathrm{k}$. de Bernardi. 1970. Iffects of Eamma and $x$-irradiation on the variety normal and albino of Biomphaleria Elabrata, Say (Gastropoda, Frosobranchiata). pp. 1137-1150. In: Actes du Synposiun International de radioecologie. Vol. 11. France Comissariat a 1 Enereite Atomique. (NiA 24-41963).

Fugh, 2. 1953. The x-irradiation of maxine cametes.

A study of the effects of $x$-irradiation at different levels on the eerm cells of the clan, Spieula

(formerly Hactra). Biol. Bull. $104(2): 197-209$.

Sasaki, $\tilde{f}$ and N. hajiwara. 1963. Bacteriostatic effect of $60_{\mathrm{Co}}$ Eanma ray irradiation on oyster. Hiroshimalien Eisei lienkyushoho (13): 22-27. (In Japanese) (iis A 21-26686).

Sato, I..., G. Austin and H. Yai. 1967. Radiation and whoie light effects on molluecan nerve cells in vitro. Radiation Res. 31(3), 452-466. (NSA 21-34761). (ApIysia californica).

Conehara, $\Sigma$. 1933. Studies on the effecte of $x$-rays upon the development of a pond snail innmaee (Badix) japonica. T. Sci. Hiroshima Univ. íer. B. Div. 1: 151-16\%. 
orio, $\therefore$ 1924. On the effects of uranium to cleavare of ojetcr ere. Imp. Fish. 20(4):

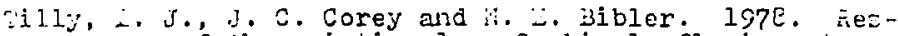
pcre of the asiatic clam, Copbicula flumines to

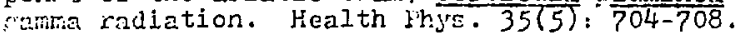

miji, r. and Y. ilorifuchi. 1966. Studies on the proAuction of black pearis by irradiation with radio ctive raye. II. un the formation of maneancserich ronine pearls in peerl oyeters. Bull. ivippon cuizan Gaklaish 32: 217-921. (itis 22-10e56).

.hita, J. C., Ir and J. U. Angelovic. 1966. F'olerences o: several marine species to Co-úo irradiation. Shesapeake sci. $7(1): 36-39$. $(6$ species of marine releowts; 2 species of marine invertebrater - rud

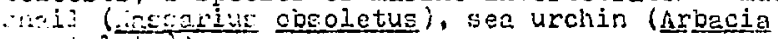
Duictulatior.

$\because x, \because$ and $c$. :un, 1965 . iffecte of camna radiation frop 60 Co on the survival roproduction and rate of infeotion of waterenails. Yuan zh ifene. (3): $272-$ 279. (ivis 20-31116).

5. isnnelidà

(iigris)

Isctard, C, 1914. The effect of radium radiations on the fertilization of IEreie. J. ixptl. zool. 16(1) $8:-129$. (rereis liniots).

alicid, $\therefore$. C. and $\therefore$. i. Eright. 1918. Temperature coifficient of the action of beta rays upon the eri of Sercis. $\because$ cen. thysiol, $1(2): 255-260$.

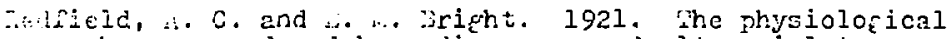
chatses produced by rediur. raye and ultre-violet licht in the of $\mathrm{E}$ of Hereie. J. Ihysiol. 55(1/2): $61-55$.

ichen-Jubois, T. 1956. ivolution du refenerat caudal d: Lereis diversicolor apres irradiation reilona aur rayons $\mathrm{X}$. Bull. LDC. Z00J. i'r. 81: 199-207. 
Townsend, G. 1940. Concernint sensitivity of cells to $x-$ raj (abetr.). Biol. Eull. 79(2): 362-363.

(Nereie and Arbecia efes).

\section{Arthropode}

(Artemia)

Aagelovic, J. $N$ and D. W. Eneel, 1968. Interaction of Eama irradiation and salinity on respiration of trire shrimp (Artemia salina) nauplii. Fadiation fies. $35(1)$ : 102-108. (रिi 22-43400).

Anelovic, J. H. and D. Al. Engel. 1970. iffects of radiation on estuarine oreanisms. Jarine Follution slill. 1(7): 103-105. (NSA 25-21845). (Summary of thei2 laboratories' research: Falaemonetes pueio, Gelii. nectes sepidue, rundulus heteroclitus, Artenia salina, Irefodon rhomboldes.

Enj.Lardin, 3. and Hetalli. 1962. Tirst results on $x$-ray-incuced genetic damafe in Artenia salina Leach. Atti. Assoc. Cenet. Ital. 7: 219-231. (NSA 16-28764).

Ballardin, i. and F. Fetalli. 1965. Selation between polyploids and radiosensitivity of oxytes of Artemia Salina Ieach. Boll. Z001. 32:613-618. (In Italian) (NSA 22-43277).

Jallardin, E. and $F$. Hetalli. 1966. Effects of $x$-rayc on oofenesis and rhythm of molting in irtemia salina Leach. 3011. 3001: 33: 195-196. (In Italien) (NEA 23-2915).

3allardin, E. and P. Hetalli. 1968. ïstimntes of some components of fitness in diploid parthenocenetic Artemia salina irradiated over several ceneratione. Att1. Aesn. Genet. Ital. 13: 341-345. (In Italian) (iNA 23-6561).

Enllardin, 7. and $t$. letalli. 1972. Firansmission of traits in parthenocenetic Artemia salina. Boll. zool. $32(4): 551-564$. (In Italian) (W. $30-367 ?)$. $\therefore-$ irradiation). 
Bonham, K. and R. F. Palumbo. 1951. Effects of $x$-rays on snails, crustacea, and algae. Growth 15(3): 155-188. (Radix japonica. Thais lamellosa, amphipod, Artemia saling. Chlorella. Ankistrodesmus, Chroococcus. Sinechococcus).

Boswell, J. L. 1966. Some effects of acute $60^{\circ}$ Co gamma radiation on four developmental stages of the brine shrimp Artemia salina (L.). Thesis, Texas A Univ., College Station. B8 pp. (NSA 21-34810).

Burlakova, Ye. V., B. L. Kakushkina and N. V. Korneyeva. 1963. X-radiation effects on Artemia salina $L$. eggs. Nauch. Doklady Vyssh. Shkoly, Biol. Nauk (3): B3-87. (In Russian) (NSA 20-35291).

Cervini, A. and S. Giavelli. 1965. Effect of low temperature on radiosensitivity of Artemia oocytes. Progr. Biochem. Pharmacol. 1; 52-58. (NSA 20-18447).

Cervini, A. and S. Giavell1. 1965. Radiosensitivity of different meiotic stages of oocytes in parthenogenetic diploid Artemia salina Leach. Wutat. Res. $2: 452-456$. (NSA 20-5359).

Easter, S. S., Jr. and F. Hutchinson. 1961. iffects of radiations of different LieT on Artemia eggs. Radiation Res. 15(3): 333-340.

Engel, D. H. and D. J. Fluke. 1961. Relation of water content to radiosensitivity for emergence of Artemia larvae from the encyated phase (abstr.). Radiation Res. 14(4): 463, abetr. 47 .

Engel, D. W. and D. J. Fluke. 1962. The effect of water content and postirradiation storage on radiation sensitivity of brine shrimp cysts (eggs). Radiation Res. $16(2)$ : 173-181. (NSA 16-17504).

Engel, D. W. and E. H. Davis, 1976. The effects of gamma radiation on the eurvival and growth of brine shrimp, Artemia salina. pp. 376-380. In: Radioecology and Enerey Resources. (C. E. Cushing. Jr. et al., eds.). Dowden, Hutchinson and Ross, Stroudsbure. PA. 
Eugeter, J. G. 1964, Suradiation experiments concerning the concept of the natural radiation environment. Aerosp. Med. 35(6): 524-526. (Artemiar, Ereen alga).

Gajewskaja, N. 1923. Elnfluss der Roentgenstrahlen auf Artemia galina, Verhandl. Intern. Ver Theor. u. Agnew. LImnol. Grund-Vers. Z. Kiel. pp. 359-362.

Grosch, D. S. 1962. The survival of Artemia populations in radiogctiye sea water. Biol. Bull. 123(2): $302-$ 316. (32: $65 \mathrm{zn}, x-$ ray $)$.

Grosch, D. is. 1966. The reproductive capacity of Aftemia subjected to successive contaminations with radiophosphorous. Biol. Bull. 131(2): 261-271.

Grosch, D. S. and H, E. Erdman. 1955. X-ray effect on adult Artemia. Biol. Bull. $108(3): 277-282$.

Hallopeau, C. 1969. Recherches de l'action eventuelie de pollutions radioactives (Cs-137, melange de produits de Iission) sur le developpement et la reproduction d'Artemia saling. Rapp. P.-v. Reun. Comm. Int. Explor. Scient. Wer biediterr. 19, 961 -

Holton, R. 2. 1968. Effects of $60^{\circ} \mathrm{Co}$ gamma irradiation on the reproductive performance of the brine shrimp, Artemia. Thesis, Oregon State Univ.. Corvallis. 81 pp. (NSA 23-33818).

Holton, R. L., C. L. Osterberg and W. O. Forster. 1973. Effect of camma irradiation on the maintenance of population size in the brine shrimp, Artemia. pp. 1198-1205. In: Radionuclides in Ecosys tems. (D. J. Nelson, ed.). U. S. AEC report CONF-710501-F2. (NSA 28-30242).

Holton, R. L., C. L. Osterbere and W. O. Forster. 1973. Effect of Eamma irradiation on the reproductive performance of Artemia as determined by Individual pair matings. pp. 1191-1197. In: Radionuclides in Ecosystems. (D. J. Nelson, ed.). U. S. AEC report CONP-710501-P2. (NSA 28-30241).

Iwasaki, $T, 1958$. Effects of water content on $x$-ray sensitivity in Artemis eggs (abstr.). Radiation Res. 9(1): 133 . 
Iwasaki, 2 . 1959. Effects of the moisture content on $\gamma$-ray sensitivity in Artemia efes. Bull. Inst. Chem. Research, Kyoto Univ. 37: 400-404.

Iwacaki, T. 1964. Sensitivity of Artemia eggs to $\gamma$-irradiation. I. Hatchability of encysted dry eggs. J. Radiation Res. 5: 69-75. (NSA 19-38383).

Iwasaki, T, 1964. Sensitivity of Artemia eegs to $\gamma$-irradiation. II. Effects of water content. J. Radiation Res. 5: 76-81. (NSA 19-38384).

Iwasaki, T. 1964. Sencitivity of Artemia eges to the $\gamma$-irradiation. IV. After-effect of irradiation in comprison with the cfoct oi hent-treatment. J. sidiation Res. 5: 97-101. (NSA 19-43815).

Iwasaki, T. 1965. Sensitivity of Artemia eges to gammairridietion. V. Biological after-effect of irradiation in relation to water content and temperature. 1. Radiation kes. 6: 11-16. (NSA 20-18342).

Iwasaki, T. 1965. Sensitivity of Artemia eggs to $\gamma$-irradiation. VII. Relationship between the degree of biological damage and the decay of free radicals in irradiated eges. Intern. J, Radiat. Biol. 9(6): 573-580. (NSA 20-8602).

Iwasaki, T. 1966. Sensitivity of Artemia eges to the $\gamma$-irradiation. VI. The effect of fractionated irradiation. biem. Coll. Sci., Univ. of Kyoto Series B (biology) 32: 177-.

Iwasaki, T. 1966. Sensitivity of Artemia eges to $\boldsymbol{r}$-irradiation. VIII. Modification of amount of radiationinduced free radicals by post-irradiation treatments. Intern. J. Kadiat. Biol. I1(2): 153-159. (NSA 2120038).

Iwasaki, T. 1971. Effects of fast neutrons and $60^{\circ} \mathrm{Co}$ $\gamma$-rays on Artemia. pp. 1-4. In: Alteration Factors of Radiation Injury. (iv. Ishida and T. Oijima, eds.). kesearch Reactor Inst., Kyoto Univ., Japan, report KURAI-TR-87. (In Japanese) (NSA 27-2819).

Iwasaki, T. 1971. Sensitivity of Artemia efes to r-irradiation. IX. A correlation between radiation-induced free radicals and hatchability in eges exposed to -mercaptoethylamine. Intern. J. Radiat. Biol. 20(1): 39-47. (NSA 25-55262). 
Iwasak1, T. 1973. Protective effect of a-mercaptoethylamine against fast neutrons in dry eggs of Artemia. Intern. J. Radiat. Biol. 23(1): 95-97. (NSA 27-24978).

Iwasaki, T. 1973. The differential radiosensitivity of oogonia and oocytes at different developmental stages of the brine shrimp. Artemia galing. Biol. Bull. 144(1): 151-161. (NSA 28-18529).

Iwasaki, T. and T. Maruyama. 1971. Comparative effects of $60 \mathrm{Co} \gamma$-rays and $29 \mathrm{MeV}$ electrons on Artemia. Intern. J. Radiat. Biol. 20(5): 493-496. (NSA 2615509).

Iwasaki, T. and $Y$. Kumamoto. 1976. The effect of oxygen on the radiation sensitivity of Artemia eggs: A preliminary result of OER on dry eges. Radiation Res. 67(1): $168-172$.

Iwasaki, R., T. Maruyama and A. Nichimura, 1973. The relative biological effectiveness on Artemia exposed to fast neutrons. pp. 25-28. InI First Report on Cancer Therapy with High Energy Particles and the Utilization of Short Lived Radionuclides in Diagnostics. National Institute of Radiological Sciences, Ciba, Japan, report NIRS-R-2. (In Japanese) (NSA $32-6786)$.

Imasaki, T., Y. Kato and S. Antoku. 1974. Study of the biological effectiveness of high-energy electrons at ultra-high dose rates uging dry eggs of Aftemia. Radiation Res. 57(2): 195-206. (NSA 29-24510).

Iwasaki, T., T. Maruyama, Y, Kumamgto and Y, Kato. 1971. Effects of fast neutrons and $60 \mathrm{Co} Y$-rays on Artemia. Radiation ReB . 45(2), 288-298. (NSA 25-26917).

lietalli, P. and E. Ballardin. 1962. Artemia salina Leach, a new material for radiobiological research. Strahlentherapie, Sonderbande $51: 126-128$. (In German) (NSA 18-1437).

lietalli, P. and E. Ballardin. 1965. Effect of $x$-radiation oil the life span of various strains of Artemia salina Leach. Boll. Z001. 32, 587-602. (In Itallan) (NSA $22-43470)$. 
Metalli, P. and E. Ballardin. 1965. On the relationship between radiation resistance and recuperation ability of Artemia salina oocytes. Paper presented at European Soc. for Radiation Biology, Section on Genetical Effects, Annual Meeting, Utrecht, Sept, 16-18, 1965. $10 \mathrm{pp}$. (Also: Comitato Nazionale per l'Enereia Nuciear, Rome (Italy) report RT-BI0-(65)3I). (CONF650968-1). (NSA 20-22618).

Fletalli, F, and E. Ballardin. 1972. Radiobiology of Artemia: Radiation effects and jloidy. Curr. Topics Rad. Res. Quart. 7: 181-240. (NSA 26-23155).

Fahl, G. 1962. Effect of irradiation temperature on hatching of brine shrimp eggs (abstr.). p. 241. In: Second Intern. Congress Radiation Research. Silver End Documentary Publications, Itd., London.

Planel, H., J. P, Soleilhavoup, Y. Blanquet and R. Kaiser. 1974. Study of cosmic ray effects on Artemig salina eges during the Apollo 16 and 17 fliehts. pp. 85-89. In: Life sciences and Space Research XII. (P. H. A. Sneath, ed.). Akademie-Verlag, G. M. B. H.. Berlin. (NSA 31-26194).

Ruether, W., E. H. Graul, W. Heinrich, O. C. Allkofer, $R$. kaiser and $F$. Cueer. 1974. Freliminary results on the action of cosmic heavy ions on the development of eggs of Artemia salina. pp. 69-74. In: Life Sciences and Space Research XII. (F. H. A. Sneath, ed.). Akademie-Verlag, G. m. b. K., Berlin. (NSA 31-26193).

Rugh, R. and H. Cluggton. 1955. Hydration and radiosensitivity. Proc. Soc. Expt1. Biol. Med. 88(3): 467-472. (Artemia).

Snipes, $W$. C. and W. Gordy. 1963. Radiation damage to Artemia cysts: Effects of water vapor. Science 142 (3591): 503-504. (NSA 17-40622).

Squire, R. D. 1969. An analys is of fitness components in the brine shrimp, Artemia salina, with reference to camma irradiation and inbreeding depression. Thesis, North Carolina State Univ., Raleigh. 129 pp. (INSA $24-14575$ ). 
Squire, R. D. 1970. The effects of acute gamma irradiation on the brine shrimp, Artemia. II. Female reproductlve performance. Bio1. Bull. 139(2): 375-385. (NSA 25-21285).

Squire, R. D. 1973. Effects of acute gamma irradiation on the brine shrimp, Artemin. III. ihale $F_{1}$ reproductive performance following paternal irradiation of mature sperm. Biol. Bull. 144(1), 192-199. (NSA $28-18530 ; 28-21776)$.

Squire, R. D. and D. S. Grosch, 1970. The effects of acute camma irradiation on the brine shrimp. Artemia. I. Life spans and male reproductive performance. Biol. Bull. 139(2), 363-374. (NSA 25-24309).

\section{(Asellus)}

Balesdent-Marquet, M. -L. 1955. Localized irradiation with $x$-rays and determination of the temporary sexual character of the isopod crustacean Asellus aguaticus $\mathrm{L}$. female. Compt. Rend. 241: 609-611. (In French).

Balesdent-Warquet, M.-I. 1955. Temporary castration by $x$-rays and determination of temporary sexual character of the isopod crustacean Asellus gauaticus $I$. Compt. Rend. 240(11): 1275-1277. (In French).

Balesdent-Miarquet, H.-I. and A. Veillet. 1958. Surgical castration, localized irradiation with $x$-rays and determination of the external sexual characteristics in the female crustacea Isopoda Asellus aquaticus I. Compt. Kend. 246:1753-1756. (In French) (NSA 127659).

(Cladocera)

Baylor, E. R. and F. E. Smith. 1958. Animal perception of x-rays. Radiation Res. $8(6): 466-474$. (Daphnia).

Harris, J. B., A. F. McBride, A, W. Fraser and V. Obreshkove. 1937. Liutations in parthenogenetic cladocera induced by $x$-radiation. Physiol. 2001. 10(3): 269275. 
Held, s. $\therefore$ and A. W. Bellamy. 1950. Irradiation responses in Daphnia maena. I. Increased resistance to $x$-irradiation under low uxygen tension. Univ. of Calif, at Los Angeles, $U$. $S$. AEC report UCLA-69. (NiA 4-3843).

rituiva, T. and T. Yagi. 1956. Effects of fission products lipon development of aquatic animals. pp. 1219-1224. In: Research in the iffects and Influences of the Nuclear Bomb Test ixplosions, Yol. II. Japan Society for the Fromotion of Science, Ueno, Tokyo. (English edition). (Daphnia pulex, boina macrocopa. Pseudorasbora p. parva, cryzias latipes).

i.ersten, K. and 3. . Snider. 1935. Daphnia magna as a biological dosimeter for soft $x$-rays. Radiology 25 : 285-288.

Lebodeva, G. j. and S. G. Sinevid. 1958. The effect of radioactive strontium upon survival and propagation in Daphnia marna. Doklady Akad. Nauk iSSR 122:586588. (In Russian) (NSA 13-2657).

sarchali, J. S. 1961. The effects of continuous eamma radiation on the intrinsic rate of natural increase of Daphnia pulex. Univ. of ivichiean. Industry Frogram of the Col1. Of Enfineering, report IF-491. vi. $68 \mathrm{pp}$.

i.arrhall, J. 5. 1962. The effects of continuous eamma radiation on the intrinsic rate of natural increase of Daphnia pulex. Ecology 43(4): 598-60n.

iarshall, J. 2. 1963. The effects of continuous, sublethal eamma radiation on the intrinsic rate of natural increase and other population attributes of Japhnia pulex. pp. 363-366. In: Kadioecology. (V. Schuttz and $A$, W. Klement, Jr., eds.). Reinhold Fliblishing Corp., NY.

i.arshall, J. i. 1966. Fosulation dynamics of Daphnia as modified by radiation stress. pp. 43-44. In Radiation Effects on Natural Fopulations. (C. A. Sacher, ed.). Division of Biological and liedical kesearch, Arfonne National Lab., Lemont. IL.

iarshall, J.S. 1966. Fopulation dynamics of Daphnia pulex as modified by chronic radlation stress. icology 47(4): 561-57?. 
Marshall, J. 3. 1967. Radiation stress in exploited Daphnia populations. Limnol. Oceanogr. 12(1): $154-158$.

ikarshall, J. S. 1969. Competition between Daphnia pulex and $D$. maena as modified by radiation stress (abstr.). Bull. Ecol. Soc. Amer, 50(2): 70 .

Cbreshkove, v. 1934. The quantitative biological effect of $x$-rays of different effective wave-lengths. Physiol. 2001. ? (3): 330-339. (Cladocera).

Obreshkove, V. and A. J. King. 1932. A change in the morphology of a cladoceran affected by $x$-ray treatment. Physiol. 2001. 5(3): 472-478. (Simocephalus vetulugs).

Obreshkove, $V$. and A. J. King. 1932. The effect of x-rays on the gaseous metabolism of a cladoceran. Fhysiol. 2001. 5(3): 457-471. (S1mocephalus vetulus).

Onanko, Yu. I. and I. A. Antlpova. 1977. Effect of chronic irradiation of cladocera. pp. 83-84. In: Radioecology of Animals. (R. M. Aleksakhin, ed.). "Nauka," Moscow. (In Russian).

snider, G. and H. Kersten. 1935. The action of soft $x$-rays on cladocera (Daphnia maena). Physiol. Zool. $8(4): 530-538$.

Snider, G. and H. Kersten. 1936. Susceptibility to soft $x$-rays of Daphnis magma during 1 ts development from eegs to young in the brood pouch. J. Exptl. Zool. $74(1), 1-6$.

Telitchenks, Ho M. 1958. Chronic effects of small doses of $238 \mathrm{U}, 232 \mathrm{Th}$, and $89+90 \mathrm{sr}$ on a number of enerations of Daphnia magna Straus. Nauchn. Doklady Vyssh. Shkoly (Biol.) (1): 114-118.

(Decapoda)

Angelovic, J. W. and D.W. Engel. 1970. Effects of radiation on estuarine oreanisms. Marine Follution Bull. 1(7), 103-105. (NSA 25-21845). (Susamary of their laboratories' research: palaemonetes pugio, Califnectes inpidus, Bundulus heteroclitus, Artemia Balina. Lagodon rhomboldes). 
Brown, F. A., Jr., M. F. Bennet and C. I. Ralph. 1955. Apparent reversible influence of cosmic-ray-induced showers upon a blologlcal system. Proc. Soc. Exptl. Biol. Med. 89: 332-337. (Uca puenax).

Brown, F. A., Jr., H. A. Webb and li. F. Bennet. 1958. Comparisons of some fluctuations in cosmic radiation and in orfanismic activity during 1954, 1955 and 1956. Am. J. Physiol. 195(1): 237-243. (Includes Uca pugnax, Triturus, Fucus, quahog).

Engel, D. W. 1967. Effect of single and continuous exposures of camma radiation on the survival and growth of the blue crab, Callinectes sapidus. Radiation Res. 32(4), 685-691. (NSA 22-19418).

Lingel, D. A. 1971. The effects of salinity, temperature and radiation on the ionic regulation of the blue crab, Callinectes sapidus. Thesis, North Carolina state Univ., Raleigh. 49 pp. (Diss. Abstr. Intern. $33(4))$.

ingel, D. $W$. 197 The radiation sensitivities of three species of \pm :dler crabs (Uca pugilator. U. puenax and U. minax). Chesapeake Sci. 14(4): 289-291. (NSA 30-9941).

bngel, D. H., E. W. Davis, J.W. Angelovic and D. E. imith. 1973. Effect of radiation, salinity, and temperature on the ionic regulation of the blue crab, Calinectes sapidus. pp. 1113-1118. In: Radionuclides in Ecosystems. (D. J. Nelson, ed.). U. S. AEC report CONF-710501-P2. (NSA 28-30234).

ilugster, J. 1964. Mutations caused by cosmic radiation. Bi id iliss. (2): 26-34. (In German) (NSA 21-6480). (Includes crab eges).

Iieberman. E. W. 1965. Stmactural and functional sites of action of uitraviolet radiation in crab nerve fibers. Thesis, Univ. of Florida, Gainesville. $186 \mathrm{pp}$. (NSA 21-20106).

hees, G. H. 1962. Effects of gamma radiation on two decapod crustaceans, Palaemonestes pugio and pugnax. Chesapeake sc1. 3(1), 29-34. (NSA 1U-21931). 
Terwilliger, R. C. and C. K. Levy. 1964. Behavioral response of the fiddler crab (Uca pugilator) to light and ionizing radiation (abstr.). Physiologist $7(3)$ : 270.

(Insects)

Blaylock, B. G. 1965. Chromosomal aberrations in a natural population of Chironomus tentans exposed to chronic low-level radiation. Evolution 19(3): 421429.

Blay lock, B. G. 1966. Chromosomal polymorphism in irradiated natural populations of chironomus. Genetics 53(1): 131-136. (NSA 20-12662).

Blaylock, B. G. 1966. Cytogenetic study of a natural population of Chironomus inhabiting an area contaminated by radioactive waste. pp. 835-846. In: Disposal of Radioactive Wastes into Seas, Oceans and Surface Haters. Intern. Atomic Enerey Agency, Vienna, Austria, publication STI/PUB/126. (NSA 20-40530).

Blaylock, B. G. 1971. The production of chromosome aberration in Chironomus riparius (Diptera: Chironomidae) by tritiated water. Can. intomol. 103(3): $448-453$.

Blaylock, B. G. 1973. Chromosome aberrations in Chironomus riparius developing in different concentrations of tritiated water. pp. 1169-1173. In: Radionuclides in Ecosystens. (D. J. Nelson, ed.). U. $S$. AEC report CONF-710501-P2. (NSA 28-30333).

Blaylock, B. L.. S. I. Auerbach and D. J. Nelson. 1964. Chronosomal aberrations in a natural population of Chironomus tentans exposed to chronle low-level environmental radiation. Dissertation of B. G. Blaylock, Univ, of Tennessee, Knoxville, vi, $76 \mathrm{pp}$. (Also, Oak Ridge Natl. Lab., U. S. AIC report ORNL3531).

Keyl, H.-G. 1958. Investigations on the karyotype of Chironomus thummi. II. Structural changes in the ealivary giand chromosomes following roenteren irradiation of embryos and larvae. Chromosoma 9(5): 441483. 
Lezzi, il. 1961. Behaviour of the puff pattern of the salivary-gland chromosomes in Chironomus under the influence of Drosophila egg contents. (Diplomarbeit). Eidgenossische Technische Hochschule, Zurich (Switzerland). $30 \mathrm{pp}$. (In German) (X-ray).

Nelson, D. J. and B. G. Blaylock. 1963. The preliminary investigation of salivary gland chromosomes of Chironomus tentans Fabr. from the Clinch River. pp. 367-372. Int Radioecology. (V. Schultz and A. H. Klement, Jr., eds.). Reinhold Publishing Corp., NY. (NSA 17-33585).

\section{(Limulus)}

Dawson, W. W. and J. C. Smith. 1959. Low level irradiation and threshold shift in the visual receptor. Science 129(3364), 1670-1671. (Iimulus).

Jawson, W. $W$. and $H$. Widerwohl. 1965. Functional alteration of visual receptor units and retinal pigments by x-irradiation. Radiation Res. 24(2), 292-304. (NSA 19-15182). (Limulus polvphemus, Rana catesbiana).

Rodkey, F. L., P.-li. Niaussat and li. Hackenzie. 1965. Effect of whole body $x$-irradiation on hemolymph proteins of Limulus polvphemus. U. S. Naval Medical Research Institute, Bethesda, (Haryland. 11 pp. (NSA 21-890?).

\section{(Iirceus)}

Styron, C. E. 1964. Observations on the ecology of a Eranite outcrop isopod. Ilrceus fontinalis Raf., with emphasis on lonizing radietion effects (abstr.). BuI1. Assoc. Southeastern B101. 11(2): 56 .

Styron, C. E. 1964. The ecology of a eranite outcrop population of Lirceus fontinalis Raf., an aquatic isopod, with emphasis on the effects of ionizing radiation. H. S. Thesie, Emory Univ.. Atlanta, GA. 
Styron, C. E., Jr. 1965. An ecological. study of granite outcrop populations of an aquatic isopod, Lirceus fontinalis kaf., with emphasis on the effects of ionizing radiation (abstr.). Bull. Ecol. Soc. Am. 46(3): 97 .

Styron, C. E. 1969. Ecology of two populations of an aquatic isopod (Lirceus fontinalis Raf.), with emphasis on ionizine radiation effects. pp. 53-60. In: Symposium on Radioecology. (D. J. Nelson and F. C. Evans, eds.). U. S. AiEC report CONF-670503.

Styron, C.E. and W. D. Burbanck. 1967. Ecology of an aquatic isopod, Lirceus fontinalis Raf., emphasizine radiation effects. Am. Midl. Nat. $78(2): 389-415$. 


\section{Echinodermata}

$\cdot i \cdot$.

-..., 1. Zasumasu, R. I. Shoger and A. Fujiwara.

Do. Effects of eamma-irradiation on Elycolysis

$\therefore$ the sea urchin eEE. J. Kadiat. Kes. $11(1): 20-$

$\because \quad(16424-39437)$.

$\therefore, \therefore, ., G ., k$. Gasvoda and V. Flood. 1949. Studies

$\therefore$ the mechanism of action of ionizine radiations.

$\because \because$ iffect of $x$-ray irradiation on the respiration sea urchin sperm. Bíol. Bull. 97(1): 44-50.

-. sbricia punctulata).

- 1903. Influence of radiation from radium on

$\therefore$ infartilizod and fertilized eggs and on the firc:

$\because$ es of development. Compt. Rend. $236: 1085-1080$.

(in rrench) (Stronglyocentrotus).

… i. 1934. The effect of radiation upon cell

Feriration. Biol. Bull. 67(2): 259-272. (Inclucies

.tacia and Chaetopterus eqEs).

$\therefore, \therefore$ 1967. Thotosensitization of sea-urchin

$\because . r m$ to lone-wave ultraviolet light by psoralen.

xitt. Cell Les it8(i): 167-169. (NSA 22-21563).

(iracentrotus lividus).

: ch. i.. C. 1971. Frompt responses of the sea urchin, ironevlo entrotus purpuratus, to ionizine radiatien. hesis, Orecon State Univ., Corvalis $200 \mathrm{pp}$.

(iniv. Microfilms order No. 71-25,063), (NSA 26$\therefore 06)$.

$\therefore \therefore C . \quad \therefore$ and $D$. J. Kimeldorf. 1974. Immediate Whavioral responses of an echinoderm to ionizing radiations. Physiol. Behav. 22(3): 393-398. (NSA $30-15974)$.

$\because$ i:. J. 1972. Introduction to the discussion on ili totic delay. Curr. Tlop. Radiat. Kes. unart. $7(3)$ : 3-322. (Nis 27-2821). (Sea urchin eqgs and radia(in). 
Evans, T. C. 1940. Effects of roentgen radiation on the jelly of the Arbraita ege. I. Disintegration of the felly (abstr.). Biol. Bull. $79(2), 362$.

Evans, T. C. 1940. Oxygen consumption of Arbacia eggs following exposure to Roentgen radiation (abstr.). B101. Bull 79; 361 .

Failla, D. 1968. Recovery from radiation-induced division delay in sea urchin eggs (abstr.). Radiation Res. $35(2), 514$.

Failla. P. M. 1962. Recovery fron radiation-induced delay of cleavage in gametes of Arbacia punctulata. Science 138(3547): 1341-1342. (NSA 17-5895).

Fallla, P, 1969. Recovery and modification of radiationinduced division delay in developing sea urchin eges. Radiology 93: 643-648. (NSA 24-2771).

Failla, P. M. and R. C. Rustad. 1970. Protein synthesis and recovery from $\gamma$-ray-induced mitotic delay in fertilized sea urchin eggs. Intern. J. Radiat. Biol. 17(4): 385-388. (NSA 24-32162). (Arbacia punctulata).

Heilbrunn, I. V. and R. A. Young. 1935. Indirect effects of radiation on sea urchin eggs. Biol. Bull. 69(2), 274-278. (Arbacia punctulata).

Henshaw, P. S. 1932. Studies of the effect of roentgen rays on the time of the first cleavage in some marine invertebrate egge. I. Recovery from roentgen ray effects in Arbacila eggs. Amer. J. Roentgenol. 27: 890-898.

Henshaw, P. S. 1938. The action of $\mathrm{x}$-rays on nucleated and non-nucleated egg fragments. Am. J. Cancer 33: 258-264. (Arbacia punctulats).

Henshaw, P. S. 1940. Further studies on the action of roenteen rays on the gametes of Arbacia punctulata. I. Delay in cell division caused by exposure of gperm to roentgen rays. Am. J. Roentgenol. $43(6)$; 899-906. 
Henshaw, P. I. 1940. Further studies on the action of rocntgen rays on the Eametes of Arbacia punctulatid. II. Wodification of the mitotic time scredule in the effs by exposure of the gametes to roenteen rays: Am. J. RoentFenol. 43(6): 907-912.

llenshaw, F. $\because$. 1940. Further studies on the action of roenteen rays on the famctes of Arbacia plinctulata. III. Fixation of irradiation effect by fertilization in the efgs. Am. J. Koentenol. 43:6): 913-0,10.

hienshaw, F. 3. 1940. Further studies on the action of roenteen rays on the fametes of Arbacia punctulata. IV. Chances in radiosensitivity during the first cleavafe cycle. Am. J. Roentqenol. 43(6): 917-920.

henshaw, F. $\therefore$ 1940. Further studies on the action of roentfen rays on the kametes of Arbacia punctuleta. $v$. lihe influence of low temperature on recover: from roenteen-ray effects in the efes. Am. $J$. Roentienol. 43(t): $921-922$.

intonshaw, P.S. 1940. Further studies on the action of roentgen rays on the eametes of / rbacia punctulata. VI. Production of inultipolar cluavace in the $E$ : by exposure of the amotes to ruentren rays. hm. J. roentgenol. $43(6)$ : 923-933.

Senchaw, $\because .3$ anc $j$. 3 . Prancis, 1936. The effect $0:$ $x$-rays on cleavage in arbacia efes: ividence of nuclear control of division rate. Biol. Eull. $70(1)$ : $28-35$.

Henshaw, F. S., C. T. Henshaw and i. E. Francis. 1933. The effect of roenten rays on the time of the first cleavage in marine invertebrate eEgs. II. Differential recovery and its influence when different nethods of exposure are used. Radiology 21, 533-541. (Sea urchin).

Hinrichs, M. A. 1926. Liodification of development on the basis of differential susceptibility to radia. tion. III. Arbacia lerm cells, and (a) ultraviolet radiation, $(t)$ visible radiation following sensitization. Blol. Bull. 50(6): 455-472. 
Hinrichs, $\mathrm{K}$. A. 1926. The effect of ultraviolet radiation on the fertilizing power of Arbacia sperm. Biol. Bull. 50(6): 473-489.

Hinrichs, M. A. 1927. Ultraviolet radiation and the fertilization reaction in Arbacia punctulata. Biol. Bull. 53(6): 416-437.

Hniao, S. C. and F. I. Daniel. 1960. Studies on the effect of ionizing radiation upon developing sea urchin. II. (abstr.). Anat. Record $137(3)$ : 365366 .

liutchings, I. H. 1963. The combined effect of ultraviolet irradiation and heat upon cleavage of sea urchin eggs. Biol. Bul1. 125(2), 302-310. (NSA 1811674). Arbacia sp.. Strongylocentrotus uurpuratus).

Ikeda, ii. 1965. Behavior of sulfhydryl groups of sea urchin eges under $b^{\prime}$ ockage of cell division by UV and heat shock. i..ptI. Cell, Res. 40(2): 282-291. (NSA 20-12624). (Anthocidaris crassispina, Clypeaster japonicus. Hemicentrotus pulcherrimus).

Kimura, H. 1974. Effects of caffeine on mitotic delay of sea urchin eggs fertilizcd with $x$-irradiated sperm. J. Radiat. Res. 15(2): 75-80. (NSA 30-19011). (Anthocidaris crassispina, Hemicentrotus pulcherrimus. Clypeaster japonicus .

Kimura, H. 1975. Effects of caffeine on cleavage delay of sea urchin eefs induced by ethidium bromide or puromycin. J. Radiat. Res. 16(2): 125-131. (Xand UV-irradiation; Hemicentrotus pulcherrimus l.

Kimura, H. 1975. Studies on C-Alap contents in sea urchin eges fertilized with normal and $x$-irradiated sperm. J. Radiat. Res. 16(2): 120-124. (Hemicentrotus pulcherrimus).

Kimura, I. 1974. Nucleic acid metabolism in sea urchin embryos and its alteration after $x$-irradiation. Expt1. Cell. Res. 89(2): 327-335. (NSA 33-9593). 
Konstantinova, M. Mi., A. C. Parasenko, I. V. Nekrasova and G. V. Dontsova. 1975. Analysis of the nature of fluctuations in the radioresistance of the sea urchin durine early embryocenesis. Radiobiologiya 15(2): 286-288. (cinglish transl. ERDA-tr-51). (NSA 33-5804).

Little, E. F. and T. C. Evans. 1940. Delay in first cleavage of Arbacia effe following roenten irradiation of zygotes (abstr.). Biol. Bul1. 7Э(2): 362 .

iravor, J. W. and D. Hi. De Forest, 1924. The relative susceptibility to $x$-rays of the eges and sperms of Arbacia. Froc. Soc. Expti. Biol. lied. 22(1): 19-21. Arbacia punctulata).

i.iwa, Bi.. H. Yamashita and K. Rori. 1939. Lethal action of alpha-rays on sea urchin egEs. Nature 144(3643): 378. (Pseudocentrotus depressus).

liwa, i.., K. Yamashita and K. lori. 1939. The action of ionizine rays on sea urchin. I. The effects of roentgen. ermma and beta-rays upon the unfertilized egers and sperm. Gans 33 (1:: 1-12.

iliwa, H.. K. Yamashita nd K. Mori. 1939. Tihe action of ionizing rays on sea urechin. IV. The effects of alpha rays upon unfertilized efes. Ciann 33(4): 323331 .

jaiwa, h., H. Yamashita and h. biori. 1941. The spern of sea urchin as a biological test object in roentên dosimetry. Gann 35(2), 127-132.

ivori, K., iv. MiWa and H. Yamashita. 1939. The action of ionizine rays on sea urchin. III. Further observations on recovery from effects of beta rays upon unfertilized eegs and sperm with additional studies on the time factor problems. Gann 33(4): 316-322.

Wotomura, I. and bi. Yamamoto, 1968. Biological effect of electron beam irradiation of small creatures. I. Res. Kep. Lab. Nucl. Sci., Tohoku Univ. I(1): 92-93. (In Japanese) (NSA 24-2127E). (Newts, Nchinus spawne). 
Nakamura. I. 1975. Change in radiosensitivity on the development of sea urchin eges durine. the early cleavage stage. II. Protection against $x$-ray irradiation by cysteamine. J. Radiat. Res. $6(4)$ : 203210. (Pseudocentrotus depressus, Hemicentrotus pulcherrimus).

Fakamura, I. 1977. Change in radiosensitivity of sea urchin egg during early cleavage stages III. Effects of split-dose irradiation with 137 Cs - -rays. Intern. J. Radiat. Biol. 32(3): 267-276. (Hemicentrotus pulcherrimus).

Kahn, 0. 1934. The physico-chemical basis of biological radiations. Symposium on Quantitative Biology 2: 226-240. (Includes sea urchin eges).

Rao, B. 1963. An analysis of $x$-ray-induced mitotic delay in sea urchin eges. Thesis, Univ. of California, Berkeley, v, $62 \mathrm{pp}$. (Also: Univ. of California, U. S. AEC report UCRL-10979).

Rao. B. and R. I. Hinegardner, 1965. Analysis of DNA synthesis and $x$-ray-induced mitotic delay in sea urchin eEgs. Radiation Res. 26(4): 534-537. (NSA 20-6861). (Stroneylocentrotus purpuratus).

RuFh, R. and K. Fu. 1965. AET as a radioprotective aEent at the cellular level. Biol. Bull. 128(1): 125-132. (NSA 19-28116). (Arbacia punctulata).

irustad, R. C. 1959. Consequences of unflateral ultraviolet radiation of sea urchin eggs. Biol. Bull. $116(2)$ : 294-303. (Stroneylocentrotus franciscanus).

Rustad, R. C. 1960. X-ray induced dissociation of the mitotic and micromere "clocks" (abstr,). Biol. Bull. 119(2): 284. (Sea urchin eges).

Fustad, R. C. 1960. X-ray induced mitotic delay in the Arbacia eggs (abstr.). Biol. Bull. 119(2): 337.

Sustad, R. C. 1967. The stimulation of amino acid incorporation into the protein of unfertilized sea urchin eegs by $\gamma$-irradiation. J. Cell. Physiol. 70(1): 7578. (NSA 22-12799). (Arbacia punctulata). 
kustad, R. C. 1970. Variations in the sensitivity to $x$-ray-induced mitotic delay durinf the cell division cycle of the sea urchin efE. Kadiation Res. $42(3)$ : 498-512. (NSA 24-34597). (Arbacia punctulata).

Kustad, R. C. 1972. Techniques for the analysis of radiation-induced mitotic delay in synchronousiy dividing. sea urchin eggs. pp. 153-181. In: Concepts in Radiation Cell Biology. (G. L. Whitson, ed.). Academic Press, NY. (NSA 26-41225).

Fustad, R. C. 1973. Nuclear-cytoplasmic relations in the mitosis of sea urchin eggs. IV. hodification of $x$-radiation-induced damage to sperm in whole eges and in haploid and diploid half-eges. Radiation Res. $54(2), 328-332$. (NSA 28-8482).

Fustad, R. C. 1973. Fartial additivity of the mitotic delays induced by separate $\gamma$-irradiation of sea urchin eges and sperm. Intern. J. Radiat. Biol. $24(2): 213-21 ?$. (NSA 29-7?1).

Fistad, R. C. ard B. R. Burchill. 1966. Radiationinduced mitotic delay in sea urchin eegs treated with puromyein and antinomycin. Kadiation Res. 29(2): 203-210. (NSA 21-14743). (Arbacia punctulata. (Lxtechinus pictus).

Kustad, R. C. and H. A. Creenbere. 1972. Prefertilization stimulation of sea urchin eees can "cure" radiation-1nduced mitotic delay. Expti. Cell kes. 75(1): 285-288. (NSA 28-2970). (Arbacia punctulata).

Rustad, R. C., S. Yuyama and I. C. Rustad. 1971. Nuclearcytoplasmic relations in the mitosis of sea urchin eEfs. III. $\gamma$-ray-induced damage to whole eqers and nucleate and anucleate half-eeEs. J. Cell. Biol. 49(3), 906-912. (NSA 26-45874) (Arbacia punctulata).

umirnova, I. B. and R. V. Latis. 1972. Role of thiols in the radiosensitivity of sea urchin eges. Doklady Akad. Nauk SSSR 203(1): 254-256. (NSA 26-45882).

Smith, Bi. E. and T. C. Evans. 1940. iffects of roentech radiation on the jelly of the irbacia eef. II. Changes in pH of ege media (abstr.). Biol. Bull $79(2): 362$. 
ipiedel, C. C. and R. H. Cheney, 1960. Comparative effects of $x-r a y$ and ultraviolet radiation of gametes on the developing sea urchin Arbacia (abstr,). Biol. Bu11. 119(2): 338 .

Tarasenko, A. G., I. V. Nekrasova and l. F. Novoselova. 1971. Correlation in radiosensitivity changes durinf: the early embryogenesis of the sea urchin introngilocentrotus nudus and fluctuations of the cell thiol content. Radiobiologiya 11(6): 900-903. (English transi. AEC-tr-7307). (NSA 26-41218).

I'arasenko, A. G.., V. I Sarvateev and I. V. Nekrasova. 1972. Radiosensitizing action of iodoacetate and KI on developing, sea urchin eges. Doklady Akad. lialik SSSR 202(6): 1438-1440. (NSA 26-50957).

Tounsend, G. 1940. Concerning sensitivity of cells to $x-$ ray (abstr.). Biol. Bull. $79(2): 362-363$. (Nereis and Arbacia egers).

'lisytsugina, V. G. 1969. Protection of the chromosomes of sea urchin Scorpaena porcus embryos from the action of Incorporated $91 Y$ with streptomycin. Radiobiologiya 9(6): 930-931. (English trans1. AEC-tr-7245). (NSA 24-16954).

Tyler, A. 1964. Effects of ionizing radiation on sea urchin sperm and mechanism of fertilization. pp. 287-295. In: Effects of Ionizing Radiation on the Reproductive System. (W. D. Carlson and F. $X$. Gassner, eds.). Fergamon Press, Oxford. (NSA 1823339).

Vaynson, A. A., A. S, Herkulov and A. H. Kuzin. 1969. Effects of radiotoxins on the development of sea urchin embryos. Radiobiologlya 9(3): 457-459. (EnElish trans 1. AEC-tr-7026). (NSA 24-9917).

White, J. C., Jr. and J. W. Angelovic, 1966. Tolerances of several marine species to Co-60 irradiation. Chesapeake Sc1. 7(1): 36-39. (6 species of marine teleosts; 2 species of marine invertebrates - mud snail (Nassarius obsoletus). sea urchin (Arbacia punctulata)). 
Yamashita, H., K. liori and K. Liwa. 1939. The actior. of ionizine rays on sea urchin. II. The effecte of roentgen, cramma, and beta rays upon fet tilized erps. Gann 33(2): 11?-121.

Gmashita, H... k. Hori and i....iwa. 1940. The action of ionizing rays on sea urcinins. $V$. The mitotic observations on the effects of roentyen rajs upon the unfertilized eges and sperm. Lann 34: 239-245.

Zeitz, I., R. Fereuson and i. Garfinkel. 1968. hadiation-induced effects on DNA synthesis in developinE sea urchin eggs. Radiation Res. 34(1): 200-208. (NSA 22-28337). (Stroneylocentrotus purpuratus, Arbacia punctulata). 
8. Miscellaneous

Shott, 2. i' and il. C. liix. 2979. Radiation eftecti. of tritiated seawater on development of the foose barnacle, follicipes polimerus. healih Fhys. Ji(s): $7.8 \dot{3}-28 ?$.

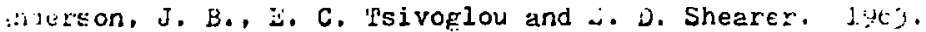
iffects of uranium mill wastes on bioloeical fauna of the hnimas fiver (Colorado - New i.exico). np. jij-383. In: Radioecoloey. (V. Schiltz arid is. Ylement, Jr.. eds.). Reinhold Fliblishinf Corp., is!. (Botton fauna, Salmo gairdnerii, alfaei.

arcill, E. A., B. G. Blaylock, C. A. Gehrs and J.. irabalka. 1977. sffects of acute ionizinf radial. on selected life stafes of the calancid copepoj Eiaptomus clavipes schact. Oak Ridpe National Lat..

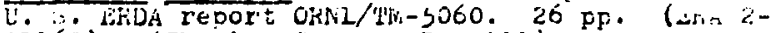
31160). (Thesis of E. A. Bardill).

$\therefore$ :ily, s. 1962. Inhibition of caudal refeneratich, $b_{3}$ $x$-irradiation in sylis amica (Annelio polyche te). Comp. Fend. $255(11): 1414-1416$. (In French) (iv:A $17-5808)$.

boilly, B. 1968. Origin of regeneration selle ir jricin ioetida Clap. (anr.nelid Folychete). darch. Siat:. licroscop. worphol. Expt. 57: 237-30e. (In Frescon) (NSA 24-17130). (x-ray).

Bonham. k. 1948. Lethal effects of $x$-rays on marine alliphi-

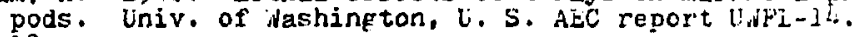
$18 \mathrm{pp}$.

sonham. $\%$ and R. F, ralumbo, 1951. Effects of $x-2$ ay, on snails, crustacea, and algae. Growth $15(3)$ : is IE8. (Hadix japonica, "thais lamellosa. ampripos, Artemia sallna, Chlorelia, Ankistrodesinus, Chrooconcui. inechocoecus :

3rdakova, Ye. V. and I. Li. Limarenko. 1961. Influetec:

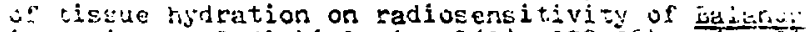
jurovisus. tadiobiolopiya $1(3): 378-364$. Teril... trans1. AEC-tr-5424; JFRS 12,387 ).

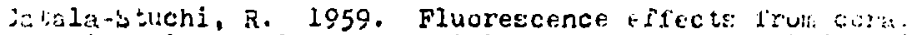

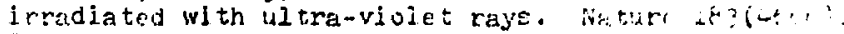
349. 
Chase, A. fi. and A. C. Ciese. 1940. iffects of uitriviolet radiation on Cypridina luciferin and lucifirase. J. Cell. Comp. Phyeiol. ib́(3): $3<3-340$.

Chesley, I: 1934: The effect of radiatiur upon cill rea-

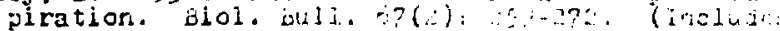

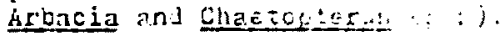

Llark, L. J. 1971. Rezcions of the spa anemone, dirthopleura xanthorramica, to acctrumancic radiations in the visible, Ultravionst ias x ray laretis. 'thesis, Oreion jtate lna ., Gorvailis. Sol pl. (Univ. bicrofilms crder ive. 71-6775), (NoA 25-26912).

Gook, J.S. 1968. On tre rolc of JNA in the liltraviole: : msitivity of cell divisior in sand dollar 2yote: . iexpt1. Cell kes. 50(3), E27-638. (NiSA 22-43432). (Echinarachritis parina).

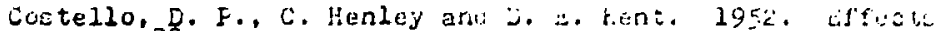

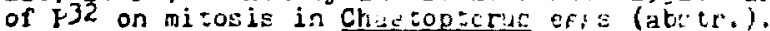
Biol. Bull. 103(2): 208-3.

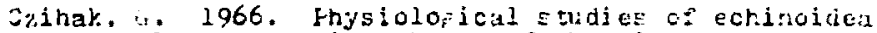
jevelopment. Disturbance of the micrciere by liv itra. diation. A contribition to the froblem of induction. and repulation. Arch. Entwickilnesmech. Orfan. 157: 199-211. (In terman) (NSi 2i-16320). (ryturechinus: miliasus).

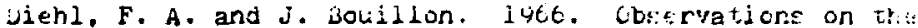
morphogenetic potentialicies of irraiated tiseut: of Cordvlophora caspia (faillae). Bull. Cl. Sci.. Acad. Roy. Bele. 52(5): 138-146. (In French) (Nik $20-45383)$.

viualvo, L. H. and A. j. Cobet. 1974. Conirol ui art estuarine microfoulinp sequence on optjcal surfaces usine low-intensjty uitraviolet irradiation. Appl. licrobiol. 27(1): 272-173. (Wja 29-27000). (ACcidans, barnacles, sessile protozoa, bacteria, diatom).

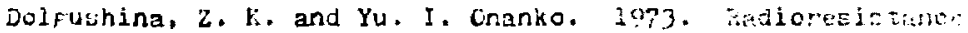
of some planktor and beritos epecies of cristaced. pp. 50-56. nt Bailoecclog of water crranicms. III. The iffect of Iorizire ksuitition on water Gr-

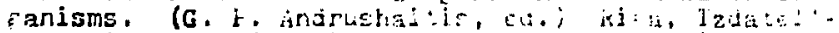

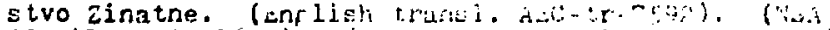

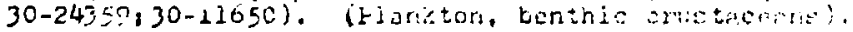


Ferguson, T. 1973. Some effects of irradiation on delayed amputation upon regeneration in Tubularia crocea. Intern. J. Radiat. Biol, $24(4): 421-425$. Intern. J. Kadiat. Biol. 24(4): 421-425. (NSA 29$18646)$.

Frecinan, G. 1964. The role of blood cells in the process of asexual reproduction in the tunicate Perophora viridis. J. Expt1. 2001. 156(2): 157-183. (NSA 1933939). (Ces1um-137 source).

Freman, 6; 1970. Reciculoenduthelial system of tunicates. J. Reticuloendothel. Soc. 7: 183-194. (NSA 24-48672). (X-irradiation).

Gehrs, C. W., J. R. Trabalka and E. A. Bardill. 1975. Censitivity of adult and embryonic calanoid copepods to acute ionizing radiation. Radiat. Res. 63(2): 382-3E5. (NSA 32-22632). (Diaptomus clavipes).

Giese, A. C. and E. J. Furshpan, 1954. Ultraviolet excitation of a stretch receptor. J. Cell. Comp. Fhysiol. 44(2): 191-202. (Crayfish).

Grosch, D. S, and Z, H. Smith. 1957. X-ray experinents wi th Bolgula manhattensis: Adult sensitivity and induced zyeotic lethality. Biol. Bull. I12(2): I7I179.

Farrison, F. L. and J. J. Koranda. 1973. Tritiation of aquatic animals in an experimental freshwater pool. pp. 425-434. Ins Radionuclides in Ecosystems. (D. J. Nelson, ed.). U. S. AEC report CONF-71050I-HI. (isSh 26-9484). (Clams, crayfish, goldfish, cettails, Fi thophora, p.lankton).

Henley, C. and D. P. Costello. 1957. The effects if $x$-irradiation on the fertilized egfs of the annelid. Chaetopterus. Biol. Bull. 112(2): 184-195.

hoppenheit, M. 1969. Radiobiological research on the tammarids (Cristacea. Ampipods). Heleol. W: s. isceresunters. 19: 163-204.

iioppenheit, if. 1972. Effects of single $x$-irradiation on the reproductive performance of females of Gammorus duebeni (Crustacea, Amphipoda). Heleol. Jise. i.eeresunters. 28(4): 467-484. (In German wi th inf Iish summary) (BA $57(1): 5341$ ). 
Hoppenheit, bi. 1973. Effects on fecundity and fertility of single sub-lethal x-irradiation of Gammarus

duebeni females. pp. 479-486. In: Radioactive Contamination of the liarine Environment. Intern. Atomic Enerey Agency, Vienna, Austria, publication i'I I PUB-313. (NSA 28-8486).

Huet, H. 1966. Study of receneration in Asterina Eibbosa Fenn. (Echinoderm, Asteroid) after irradiation with $x$-rays. Compt. Rend. Soc. Biol. 160: 466-469. (In French) (NSA 21-3445).

Jordan, N. li. and D. J. Kimeldorf. 1971. Visual response of the purple shore crab, Nemigrapsus nudus, to ionizinf and non-ionizing radiations. Fxperientia 27(6): 653-655. (ISA 25-49272).

kimeldorf, D. J. and R. W. Fortner. 1971. The prompt detection of ionizing radiations by a marine coelenterate. Radiation Res. 46(1): 52-63. (Anthopleura xanthorrommica).

Korotkova, G. F. and G. P. 'l'okin. 1965. Responses of sponges and coelenterates to 3 -irradiation. Radiobiologlya 5(2), 290-197. (English transl. AEC-tr6599). (NSA 19-24353).

Korotkova, G. F. and G. P. Tokin. 1969. Stimulation of the processes of somatic embryogenesis in some Forifera and Coelenterata. III. Effect of irradiation on the formative processes in spones and Coelenterata. Acta Biol. Acad. Sci. Hung. 20, 141-152. (NSA 2432281).

ii, Y., T. Hu and TI. Fane. 1964. Sensitivity of Bunodactis asiaticus Uchid to 60 Co gamma radiation. pp. 113-114. In! Chung Kuo Hai Yane hu Chao Heueh Hui 1963 Nien ksueh Shu Nein Hui Ima Wen Chai Yao Hui Pien. Peking. (In Chinese) (NSA 20-45385).

Iiu, C. K. 1948. X-radiation effects on restitution of dissociated ijicrociona (abstr.). Biol. Bull 95(2): 259.

Lohmann, W., C. F. Fowler and J. H. Ferkins. 1963. Effects of roenteen rays on the enzyme-substrate (luciferase-luciferin) system of the crustacean Cypridina. Acta Radiolorica (N. i.) 1: 183-189. (NSA 17-38759). 
Lynch, W. F. 1958. The effect of $x$-rays, irradiated sea water and oxidizing agents on the rate of attachment. of Bupula larvae. Biol. Bull. 114(2): 215-22:. (Bupula turrita, Bufula flabellata).

I.icquart-lioulin, C., S. Honnier and P. Race. 1973. ixperimental contamination and radiation effects on planktonic crustaces, pp. 89-96. In: Seventh liattional Colngress of the Health Physicists' Association. Centre National de la Racherche Scientifique. liarseilles, France. (In French) (NSA 30-7116). (iurydice inernus).

May, R. Wh. . H. Maria and J. Guimard. 1964. Differential action of $x$ and ultraviolet rays on the tardierade ilacrobiotes areolatus in the active and desiccater state. Bull. Biol. France Bel". 98(2): 349-36\%. (In French) (NSA ig-38373).

ookerjee, A. 1968. Extraction and $x-r F y$ denaturation studies of sponge and hydra DNA. Jci. Cult. (1.:.., 34: 105-108. (NSA 22-51407).

Niaussat, P.. H. Vachon, J. H. Ebersoli, A. Eoisson and C. Crenot. 1965. Radioresistance of the limule xiphosura polyphemus 1 . and modifications of $i t s$ nucleic acids after $x$ and eamma irradiations . Compt. Rend. 260(6): 1795-1798. (In French) (NSA 19-21900).

U'irrien, J. P. 1946. Studies on the cellular basis of refeneration in Naie parafuavensis and the effect. of $x$-rays thereon. Growth 10(1:25-44.

Cka, S. 1954. Radiosensitivity in Lophopodella cartexi, a fresh water bryozoan. Sci. Rept. Tokjo Buririka Daigaku 111: 211-21?.

backard, $C$. 1918. The effect of radium radiation on th: development of Chaetopterus. Diol. bull. 35(1): 50-70.

ladilla, G. is. and F. A. Van Dreal. 1963. Fadiatiorinduced division delay in exponentially and sycr:?... nously dividing 4stasia loner (abstr.). J. Cill $\therefore$ 19(2): $54 \mathrm{~A}$. 
Fatel, $S$, and B. Fatel. 1971. Effect of ionizinf radistion on haemorlobin of merine lamellibranchs. i..rint Biol. 10(3): 272-279. (NEA 26-12231).

Fatel, $\dot{j}$ and 3. Fatel. 1973. iffect or ionizin" radiation on the blood of a marine polychaete worm: har. physa mossal.bica Feters. pp. 1206-1212. In: Radionuciides in ticosystens. (0. j, ivelson, ed.). U. $\therefore$. AEC report CONF-710501-5E. (NSA 28-30243).

Ftisl, F. and 3. tatel. 19?3. sifect of ioni-ing radian tinns on haenoglobin of a tubificid worm iubifex $\mathrm{sp}$. pp. 487-497. In: iradioactive Contamination of the tharine invironment. Intern. Atoinic intery dfenci, Vienna, Austria, publication $2 I / 1-3 E-313$. (Nis $28-8331)$.

ictri, V. N. (ed.). 197(1. iffects of ionizinf radiatior, on hydrobionts and Iand piante. Iir. Inst. jkol. kast. Zhivot. (74): 1-98. (In ruseian) (N\$2524462). (isox Iuci.is, Iunica tunjca, Lymnaca sta nalis, alfae).

Iuckett, i. 0 . 1936. The effects of $x$-rediation on the refeneration of the hydroid, Eennaria tiarella. Biol. Bull. $70(3): 392-99$.

iazyulite, R. N., k. k. Yankyavichyus, z, F. vendan,

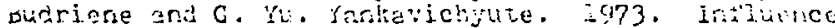
of $\gamma$-rays and temeorary fractors on planktonic bioceonosis. pp. 73-77. In: Ladioecology of water crfanisms. III. ihe effects of Ionizin kadition on iater orfanisms. (G. F. Andrustiaitis, ed.). (inflish transi. Aic-tr-7592). (NSA 31-1154). (13 species of algae, 8 species of zooplarikton).

rodrjmez, A. 1976. Eehavioral and Electrophyeiolocical evidence for the mechanisms involved in the detectiun. of ionizing radiations by the crayfish Facifastacus trowbrideif. Dissertation. Crezon state Univ., Corvallie, 104 pp. (Liniv. hicrofilne Order No. ?:29,987). (NSA 33-29759).

savafaon, .. A. and A. Sreenivasan. 1975. Kadianioninduced increased melanosis in crustacean shellfist:. Fadiation Res. 64(3): 624-632. (NEA 33-150/4). (Eenaeus indicus, Eanulirus nol.irus). 
schuidt, N. $\mathrm{N}$. 1946. The axial pradients of injur, 3. to the effects of $x-r a y s$ and other arents ia jenth... coelum lacteum: Doklady Akad. Nalik SSSh 53(3T: $7 \mathrm{t}$. 70.4. (In Enf lish).

- thmidt, N. h. 1949. 'ithe effects of $x-r a y s$ on thes organism in relation to its pclar differentiatiot. suthor's summary of thesis for Jesee of Candicti: of Bioloeical Gciences. Leningrad, Leninfrad St: Univ. $15 \mathrm{pp}$. (In kussian).

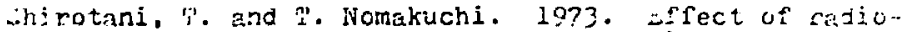
nuclides on the development and proliferation of marine products. pp. 22-32. In: Investifation $\because$ the Effects ot Low Concentrations of Radionticiicis: on squatic life. Nuclear iafety iesearch Arsoc., 'l'okyo. (In japanese) (iNaA 31-8959). (Cioria interinalis).

Sthier, W. F., W. Helm, J. W. Anelovic, D. W. jis.

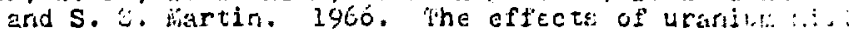
wastes on $\mathrm{stream}$ oista. itah Agr. Expt. 3ta., Lie' tate lniv.. Lopan. Bulletin 462. 7t pp.

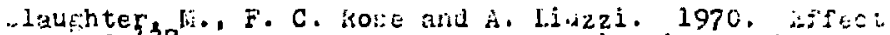
of $137 \mathrm{Cs}$ ramma rays on refeneration in fubularia. Biol. Buli, $138(2)$ : 194-199. (NSA 2t-4t5E?).

Sutton, . W. 1965. Effect: of ionizine rejiation: peritrichs. Finesis, Howarg Univ.. Vachidia is: 2. 95 pp. (NAA 20-16295). 
B. VLRTEBRATES

\section{Fishes}

Al-Daham, N. F. 1970. Use of chemosterilants, sex hormones, radiation, and hybridization for controlling reproduction in ilapia species. Thesis, Auburn Univ., Auburn, AI. $176 \mathrm{pp}$. (Univ. i/icrofilms order No. 70-22,269). (NSA 25-16326).

Aleksan'yan, O. la. N. R. hosinove rnd $T$. li. lirylova. 1978. Effects of strontium-90 and metaphos on Cyprinus carpio. Radiobiologiya 18(1): 131-134. (English transI. pp. 159-163). (ERA 3-51246).

Aleyander, $F$. and K. A. Stacey. 1959. Cross-linkine of deoxyribonucleic acid in sperm heads by ionizing radiations. Nature 181+(4691): 958-960. (Fish sperm).

Allen, A. L. 1958(?). Cross responses. I. The effects of $x$-irradiation upon embryonic development in the paradise fish, hacropodus opercularis. Brifhan Youne Univ.. U. S. AEC report APCU-3978. $46 \mathrm{pp}$. (NEA 13-4389).

Allen, A. 1. 1958. The effects of $\mathrm{x}$-irradiation upor, embryonic development in the paradise fish, i.iacropodus opercularis, with some notes on normal states. Bripham Youne Univ. U. S. AEC report AECU-3967. 3 ? PP. (NSA 13-P35I).

Allen, A. L, and L. lil. Wulkay, 1960, X-ray effects on embryos of the paradise fish. with notes on normal stapes. Growth 24(2): 131-168. (NSA 15-27435).

Al'shits, L. K., N, A. Timofeyeva and N. V. Kulikov. 1970. Influence of $60 \mathrm{Co}$ gamma-rays upon embryonic development of the pike (Esox lucius L.). pp. 12- . In: Action of Ionizing Radiations upon Hydrobionts and Land Plants. Tr. Inst. Ekol. Rast. Zhivot., Sverdlovsk 74. (In Russian).

Amano, Y.. H. I'ozawa and A. Takase. 1956. Studies on fish contaminated by radiation. Nippon Suisan Gakkaishi (Bull. Jap. Soc. Sci. Fisheries) 2l(12): 1261 . 
Alnano, Y., K. Yamada, II. Gfuii, A. Takase and s. Lenaka. 1955. Studies on fish contaminated with radiaisur. I. Radiation of fish tissue. Nippon - uisan sarkiti. i.: (sull. Jap. zoc. Zci. Ficheries) 20(10): 907.

Anders, A., F. Anders and $\therefore$. kase. 1969. ZY females caused by $x$-irradiation. Experientia $25(6)$ : E? (Elatyooecilus maculatus).

inders, A., $\vec{F}$. Anders, N. lorster, K. Rilinke and $\alpha$. Fas 1970. $X X-, X Y-, Y Y-? \$$ and $K-, X Y-, Y Y-C^{\prime 1}$ be $i$ Elatvpoecilus maculatue (Foecillidae). Verh. Dtec... 2001. Ges 1969, 2001. Anz, 33(suppl.): 333-

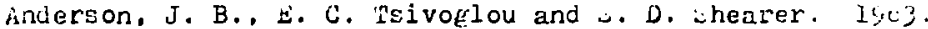
cffects of uranium mill wastos on biolofical fainit of the Animas kiver (Colorado - New i.exico). pr. 373-3e3. In: radioecolog: (V. wchult and is.... r.lement, Jr., ede.). jieinhold jublishing Corv.,... (Bottom fauna, ialno rairanerii, algae).

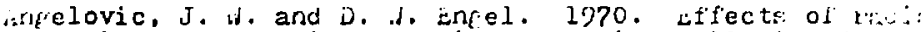
tion on estuarine oreasisus. barine lollution jud. l(7): 103-105. (ivis 25-21845). (wuminary of thicis. laboratory recearch: Falaetionctes pueio, Callinech. Eapigus, lunculus heteroclitur. irtenia saline. Iafodon rhomboides).

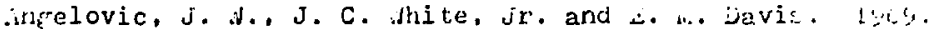
Interactions of ionizing radiation, salinity, ars cemperature on the estuarine fish, rundulus hetero. clitus. pp. 131-141. In: Eymposiun on kadioncolo;,

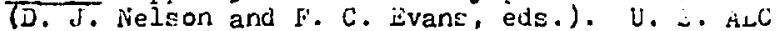
report $\mathrm{CONF}-670503$.

inonymous. 195?. nadiation effect on fish - new stik. . Atomic $8(2): 3 \varepsilon$.

Anonymous. 1964. Biolocical ctudies. Biochemistry ani biophysics; Cytology and morpholocy; Ihysioloc; ienetice. $\mathrm{pp}$. 19-56. In: Annual ireport, 1963 . National Inst. of Madiolofical Sciences, Chiba, war. . report iIf:-3. (N-A 19-31070). (Includes stujier of silkworm spernatozonie, artenia etes and irrauia.... Caracsius auratus).

roki, $k$. 1963. The effect of whole body $x$-ray irraitis tion on the hematopoietic tis sue in cold $\mathrm{f}$ sh. Larasius auratus: zoolorical (jolyo) $72(10)$ : (In japanesc) (ivis of je pan $3(5): 010 \% 0$ ). 
Aolid, li. 1966. affect of temperature on changer in number of hematopoietic cells: and mitoris in the head ridne:

in the $x$-irradiated goldisish. Jap. I. Ichthyol. 14:

$\because 90$.

sakulina, io. D.. C. L. Iokrovekaya ano D. D. Komashov. 19i2. Cn radiosensitivit $j$ of loach (11. iseurnus

roivilie I.) sperila to:03. Kadi biologiva 2(1):

92-100. (English trans1. Aje-ir-5428). (Niji 16$30301\}$.

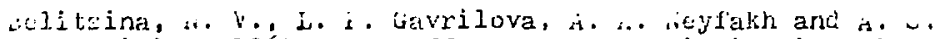

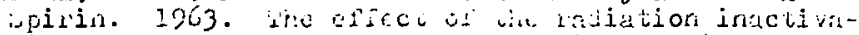
tion of nuclei on tice eynther is of information riborucleic acid in the errbryos of groundine fish

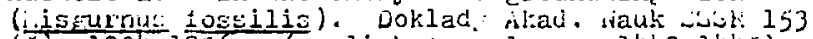

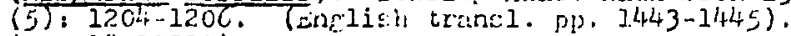
(idun $1:-11722)$.

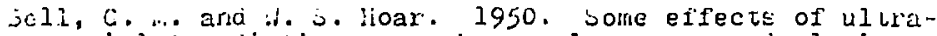
violet radiation on sockeje salmon effe and alevins. can. j. jes. 2ED(1): 35-43. (Oncorhynchus nerka).

ic 1.ajeva, V. il. anci G. L. rokrovslsa:e. 195?. Arrest of :-i cosis by $x$-rays at early developmental stafes in

loach spawn. Doklady skad. riauk sisin ll9(1): 361 36. (Enrlien tran:1. pp. 149-153).

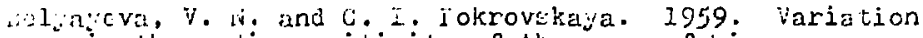
in the radiosunsitivity of the eres of biskurnus loesilis 1 . obcerved in the coures of the firet tuibryonic ini tos: Doklad: iskad. wauk jojk 125: 632-635. (wnylish transl. pp. 192-195). (.... 13$12382)$.

jilayeva, V. H. and C. 1. Eokrovskaye. 1906. Cinange in radioseneitivit' of eges of loach in procese of initial enbryonic mitosis. Ini wecond International OceanoEraphic Congress. l.oscow, Fublishine House of the Academy of Sciences USSR.

jinzlock, E. G. 1969. The fecunity of a Cambusia affinis affinis population exposed to chronic environnental raciation. Fadiation kes. $37(1): 108-117$.

ilajlock, B. G. and n. J. i.itchell. 1969. the effect of temperatire on the dose lesponse of Gallbusia arinis afrinis from two netural popuiations. riatiation kes. l:0(3): 503-511. (N..A $24-14590$ ). 
Blaylock, B. G, and N. A. Griffith. 1971. Lffects of acute beta and gamma radiation on developine enbr.os of carp (Cyprinus Carpio). Kadiation Res. 4E(1): 99-104. (NSA 25-32581).

blajlock, i. G. and H... I. Frank, 1978, the effect of ionizing radiation on the thermal tolerance of mosquitofish. pp. 785-793. In: Energy and snvironmental stress in Aquatic systems. ( $J$. H. Thorp and J. $a$. jibbons, eds.). U. S. JOe report CONF-?71114. (DCE Symp. Series No. 48:. Garatusia affinis).

Bonet-haury, F. 1963. Biological effects of ionizing radiations on the folden carp. Compt. Rend. ioc. 3io1. 157(3):473-477. (In French) (NSA 17-33iss).

Bonharn, K. 194t. Histolofical effect of $x$-ray on adult maje silver salmon, (Cricorhynchus kisutch valbaun). Univ. of dashington. $\bar{U}$. $J$. ACC report U.rFi-4. 75 i. .

نonham, $K$. 1946. Section 10 of series of experiments involving the effect of $x$-ray on fishes: Fingerlint chinook salnion (Oncorhynchus tschawytscha daloaum). Univ. of washington, U. S. AdC report U.lli-3. 71 kp.

sonham, K. and A. H. Jeymour, 1947. sections 1 and il of a series of experiments involvine the effect of $x$-ray on fishes: Chinook salinon (Oncorhynchus tschawytscha ialbaum) observed through more than one generation. Univ. of dashington. U. 3. iel re. port U.MI-6. $41 \mathrm{pp}$.

Bonham, K. and A. J. welander. 1963. Increase in radioresistance of fish to lethal doses with advancint embryonic development. pp. 353-356. In: Radioecolokgy. ( $V$. Echultz and $A$. Ki. Klement, Jr.. eds.). Reinhold Fublishing Corp., NY. (INSA 17-33584).

Bonham, K. and I. R. Donaldeon. 1966. Low-level chronic: irradiation of salmon eEgs and alevins. pp. $4 C 9-\varepsilon \varepsilon 3$. In: Disposal of Radioactive .astes into Seas. Cceans: and wrface vaters. Intern. stomic EnerEy ifency, Vienna, Austria, publication $\mathrm{s}^{\prime} \mathrm{I} / \mathrm{I} \cup \mathrm{B} / 126$.

Bonham, K. and $I$. $k$. Donaldson. 1972. sex ratios and retardation of gonadal development in chronically famma-irradiated chinook salmon smolts. irens. sis. Fish. soc. $101(3)$ : $42 \varepsilon-4+34$. 
Donham, i., I. R. Donaldson, R, F. Foster, A. D. Welander and A. H. Seymour. 1948. The effects of $x$-ray on mortality, weicht, leneth, and counts of erythrocytes and hematopoietic cells in fingerline chinook salmon, Oncorhynchus tschawytscha (Walbaum). Growth 12(2): 107-121. (Also: Univ, of Washington, U. $ড$. Aic report U.isi-3a; $\mathrm{DDC}-1416)$. (NSA 1-1087).

srown, $V$. $\mathrm{i}$. and $W$. I. Templeton. 1964. kesistance of fish embryos to chronic irradiation. Nature 203(4951): 1257-1259. (NiA 18-43273).

Zwehringer, $i$. 1973. Radiosensitivity of the rainbow trout ( almo Eairdneri Kich.) during embiyonal and larval development. Arch. Fischereiwiss. 24(1/3): 51-63. (In German) (ivis 30-3634).

Shakpitak, s. 1967. The effect of Eamma radiation on the hatchability, rate of Erowth, and reproduction of the fish. Trichogaster pectoralis keran. Tha:.land Orfice of A tomic Enerey for Peace, Bankkok, report thaI.AiC-13. II pp. (In Enflish and Thai) (iNSA 24-21282).

Chavin, 4 , and $3 . N$. Bouwman. 1963. Effect of radioiodine on the depression of thyroid iodide uptake in eoldfish, Carrasius auratus L. (abstr.). Am. 2001. 3(4): $539-540$. (BA $45-54046)$.

Chee, F. C., K. J. Vetter and G. J. Atchison. 1979. Lffect of dose rate on survival time in the fathead minnow, Plmephales promelas. Radiation Res. 77(1): 98-102.

Cherfas, N. B. 1962. Radiation damage to carp gonads. Vopr. Ikhtiol. 2(1): 104-115. (BA 40-17348).

Conte, F. F. 1965. Iffects of ionizing radiation on osmoregulation in fish oncorhynchus kisutch. Comp. Biochem. Physiol, 15(3): 293-302. (BA 46-106011).

Cooper, I. I. 1963. The effects of antibiotics and $x-$ irradiation on the survival of scale homoerafts in Fundulus heteroclitus. Diesertation, Brow Univ., Erovidence, RI. (Diss. Abstr. 24-3890).

Cooper, L. 1. 1964. The effects of antibiotics and $x$ irradiation on the survival of scale honofrafts in Fundulus heteroclitus. Transplantation 2(1): 2-20. (ก) $18-19726)$. 
Corcella, E. 1930. Influsso delle radizzoni roenteen sullo svilluppo emirionale dei T'eleostei (ulmo lacustris I, 'almo irideus iti. Eerca fluviatilis I.). Fiv. Biol. IIIlano 12: 93-117.

Cosgrove, ü. L. and B. .. Blaylock. 1973. foute and chronic irradiation effects in nosquito fish at 15 or $25^{\circ} \mathrm{C}$. pp. 579-594. In: Kadionuclides in Ecosysteme. (D. J. Jelson, ed.). L. S. AilC report CUNF-710501-1-1. (NiAA 28-27624).

Cos rove, G. E., S. G. Hlaylock, G. L. Llrikson and F. I. . Cohan. 1975. Kadiation-induced henatopoietic lesions in fish. pp. 463-476. In, the Fathology of Fishes. (iv. E. kibelin and i. inlfaki, eds.). Univ, of ilisconsin prese, iladison, WI.

Datroweki, K. and S. Tucholeki. 1973. Nplyw chroniczne; o i okresoweto oddzialyvania zelaza radioaktywne 0 $59 \mathrm{Fe}$ na ro-woj embrionalny troci (jalmo trutta 1.$)$. 2 jazd Hydrobioloe ow lolikich w. Foznaniu 3-ह wnesnia (1973). Streperenia referatwo. Foznan. pp. 97- .

Davison, C, and F. Ellinfer. 1942. Kadiation effects on nervous system and roenten pifnentetion of foloils (Caraseius auratue). Froc. . oc. Exnti. Siol. bed. $49(3): 491-495$.

De Franciscis, 1... U. De sella and V. .uto. 1961. jotal Lody $x$-irradiation in carps. Azompraxis $7(\varepsilon)$ : 292294. (NSA 15-29013).

Detlaf, T. A. and A. S. Ginzburf. 1956. r'he emoryonic development of the stureeor in connection with problems $\rightarrow$ ureedine. Izd. Hi sisil. (In zussian) (Irradiation;.

Jokholyan, v.K., B. E. hostrov and J. i. bitjutskaja. 1973. Accumulation of $90 \mathrm{Sr}, 90 \mathrm{Y}$, and the effect on those elements diseolved in water on entryonic development of some fish species in the Caspian see. pp. 36-44. In: Radioecology of dater creaniene. III. The iffect of Ionizinf Radiation on vater Crraniems. (ii. F. Andrushaitis, ed.). kifa, Irdatel'gtvo Zinatne. (Enelish tranel. AEC-tr7592). (NSA 30-24;0C; 31-11669). 
Jo3.eushina, 2. K. 1977. Influence of external $\gamma$-irradiation in combination with chlorophos upon eEgs and larvae of pike-perch. pp. 73-74. In: Radioecology of fnimais. ( $\bar{k}$, li. Aleksakhin, ed.). "Nauka," inoscow. (In kuesian).

JolEukhina, 2.K., I. G. Zaitseva and I. I. Yakubova. 1977. Action of dissolved fractions of oil in combination with irradiation on the development of pike eges. pp. 75-76. In: Radioecology of Animals. (….. Aleksakhin, ed.). "Nauka," hoscow. (In Russian).

jol ruehina, 2. K., I. L. Zaitseva and I. I. Yakubova. 1977. Changes of some physiological characteristics of carp under influence of oil and irradiation. py. ?4-75. In: nadioecolory of Animals. (R. L. . Aleksakhin, ed.). "Nauka," fioscow. (In Russian).

jonaluson, 2. F. 1945. Lquipment and procedures used in the stludy of the effects of irradiation of fish with $x$-raye. univ, of lashington, $U$, $i$. ALC report U.JFI-I. $35 \mathrm{pp}$.

jonaldson, 1 . $k$. and $k$. Eonham, 1964. Effects of lowlevel chronic irradiation of chinook and coro salmon efge and alevins. Trans. Atr. rish. ioc. 93(4): $333-341$.

Jonaldson, $\dot{i}$. K. and $K$. Bonham. 1970. Effects of chronic exposure of chinook salmon eges and alevins to grama irradiation. Trans. Am. Kish. soc. 99: 112-119. (Nit 24-29877).

suluundson, ¿. H., Jr. 1971. Effects of acute ganma radiation and temperature on erowth and survival of juvenile raintow trout (Salmo eairdneri). Dissertation, íashington State Univ., Fullman. ix, $4 \varepsilon$ pp.

Ecinundeua, E. H., Jr. 1976. Effects of gamma radiation and temperature on Erowth of juvenile rainbow trout (salmo gairdneri). Northwest sci. 50(3): 163-188.

Leami, H. 1963. studies on variation in number of anal fin rays in uryzias latipes. Effect of $x$-irradiation. Copeia (3): 592-593. (NSA 19-102).

Sfani, N. 1967. Cell population kinetics and agine with epecial reference to effects of temperature and radiation on cell renewal eystems in fish. Jikken keitaifakushi 21: 366-37E. (In Japanese). (NoA 23$33(55)$. 
Egami, N. 1969. Kinetice of recovery from injury after whole-body $x$-irradiation of the fish Oryzias latipes at different temperatures. Radiation kes. 37(1): 192-201. (NSA 23-16416).

EFami, N. 1969. Temperature effect on protective action by cysteamine against $x$-rays in the fish, oryzias latipeE. Intern. J. Kadiat. Biol. 15(4): 393-394.

Jgami, N. 1972. Repais potency and afing in oreanisme. Chanfe in regeneration rate with are in the teleost, Grvias latipes. Saibo Jeicutsueaku hinpojiunu 23: 203-206. (In Japanese) (INSA 28-30225). ( $\mathrm{x}$-ray).

Erami. N. 1973. Hereditary effect of external radiation. pp. 174-201. In: Kadioactivity and Fishes. Contamination, Injuries, and Vtilization. (N. Egami, ed.). Koseisha Kosei Kaku, Tokyo. (In Japanese) (NSA 2013025).

ZFani, N. and $\pi$. Ztoh, 1962. Dose-Eurvival time relationship and protective astion of reserpine aeainst $x$-irradiation in the rish, crialas lotipes. finnot. zool. Japa.2 35(4): 188-192. (3101. Abstr. 45(2): 4682 ).

irami, N. and Y. Hyodo. 1965. Fsects of $x$-irradiation on oviposition of the fish. urizias latipes. pp. 4\%45. In: Annual keport of kadiolofical siences, Science and Iechnolory Afency, Japan, report iviti-4.

EEami, N. and $Y$. Hyodo. 1965. Inhibitory effect of $x$-irradiation on the development of the ovaries of the fish, omzias latipes, in sexually inactive Eeasons. Annot. 2001. Japan 38: $\overline{-111}$. (NSA 2014307).

Leami, N. and $H$. itoh. 1966. Effect of temperature on the rate of recovery from radiation-induced danaie in the fish Oryzias latipes. Radiation kes. 27(4): $630-637$. (N5A 20-22731).

Leami, $N$, and $K$. lionno. 1966. Effect of $x$-irradiation on fertility of the male of the fish Oryzias latipe:. pp. 30-31. Ini Annual Report 1965, National Insti.tute of Radiological cciences, Science and Technology. Japan, report iNIFis-5. 
andi, is and k. Aoki. 1966. Effects of $x$-irradiation applics to a part of the body on the ovary of the loacti, isgurnus anguillicaudatue. p. 28 . In: Annial keport 1965. National Institute of Radioiosical ciences, cience and Technolog' Afency, iarian, rciport NIki- -5 .

$\therefore$ uni, i, and $Y$. ifyocio-Taguchi. 1969. hermaphroditic onade produced in uryzias latipes by $x$-radiation curing embrycnic stages. copeía (1): 195-196. (iivi 23-i+5910).

$\therefore$ ani, N. and 1. Hyodo-llaguchi. 1973. Dominant lethal ilitation rates in the fish, Oryzias latipes, irradiatE: at various strges of gametogenesis. Fp. 75-81. In: Genetics and itafenesis of rish. (J, $H$. chroder, ed.). Springer-VerlaE. NY.

$\because a ! n i$. N. and $\because$. Iasuchi. 1973. Inhibition of formation of svermato oa of killfishes bred in tritium solution. po. 6-17. In: Investication of the kffects of Low concentrations of Radionuclides on fquatic Life. Vucleer safety Research Assoc., Tokyo. (In Japanese) (

Ari. $\therefore$ and $i$. Eto. 1973. Lomatic effect of external irradiation on mature fish (compendium). pp. 65-91. In: Falioactivity and Fishes. Coniamina ion, injurjes. and vtilization. (N. Eeami. ed.). roseicha losei Kaku, Tokyo. (In Japanese) (NidA 29$13024)$.

Erami, N. and A. Hama, 1975. Dose-rate effecto on the ratchability of irratiated embryos of the fish. Cryaias latipes. Intern. J. Radiat. Biol. 28(3): 273-278. (TivA 33-20526).

iraiai, iv., 'i'. Chshime and Y. H. Nakanishi. 1965. Inhibitor $:$ effects: of $x$-irradiation on the development 0. ma $i$ characteristics in females of the teleost, cryalas latipes, kept in water containing methyltestosterone. Jap. J. 2001. 14:31-43. (NEA 20$16263)$.

carri, iv., $Y$. fijodo and $Y$. Ito. 1966. Inhibitory effect of $x$-irradiation of enbryos on testis formation in cruzias latipes. pp. 31-32. Int Annual keport loús, iitional Inctitute of Radiolocical ciences, -cience

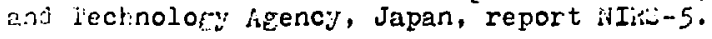


Leani, i.., Y. HJodo-Tlaguchi and $K$. Konno. 1967. Autaradiographical studies on spermatorenesis in the iich, Orvaias latipes, with special reference to radistion effect: on fertility of fish. Gunna jinp. indocrinol. 4: 147-159. (NSA 23-913).

Lrami, H., k. eto and i. Taruchi. 1973. iffects of external irradiation on the bodies of adult fiches; (consideration in detail). pp. 92-173. In: hadioactivity and $\bar{r}$ ishes. Contamination, Injuries, and Utiliration. (is. Jeami, ed.). roseisha losei raku, Tokyo. (In Japanese) (NiA 29-13023).

Egani, iN., It. itoh, C. Tachi and Y. hyodo. 1962. Felationship between survival time after exposure to $x$-ravs and dose of the irradiation in the fishes, Carassiue auratus and Oryzias latipes. Dobutsueraku zasshi 7I: 313-321. (In Japinese) (iin a 19-2098).

irami, N., H. Etch, C. bachi, K. Aoki and k. Arai. 100?. kole of the pituitary gland in melanization in the skin of the goldfish, Carassius auratus, induced by $x$-ray irradiation. Fros. Japan Acad. 3E: 345-347. (iHSA 17-12167).

Léani, N., H. Etoh, Y. Hyodo-Papuchi, $k$. Sanaka and it. Yoshimura. 1970. Effects of low radioactive effluent on fisheries propagation. keport on the Influence of Low Concentrations of hadionuclider in fater to $\mathrm{hr}_{1}$ ia if Crranisms. iuclear jafety hesearch issoc, of Japan. pi.7- . (In japanese).

Lisler, k. 1961. Effects of visible radiation on salmonid embryos and larvae. Growth $25(3): 281-346$.

illinrer, $i t$. 1939. Note on the action of $\mathrm{x}$-raye on $\mathrm{ci}:$ Sish (Carassius auratus). Froc. ioc. Exptl. Bioi.. i.ed. 4I(2): $527-529$.

Ellinger, F. 1940. ZoentEen Titrenterion in the roldfieh. Eroc. Eoc. Ixpt1. Biol. Wed. $45(1)$ : 148-150.

slinger, F. 1940. The goldrish at a new biologic tes: object in experimental radiation therapy. radiolory 35: $563-57 t^{4}$.

nlinger, $\mathrm{r}$. 1945. Lethal dose studies with $\mathrm{x}$-rajc. radiology lit(2): 125-1!1. (Goldfish). 
..llinger, $r$ and $i$. Gross. 1941. Depth dosage measureinente by ineans of goldfish. Kadiology 37(6): 717-723.

Lling"er, $\mathrm{i}$. and $\mathrm{C}$. Davison. 1942. Changes in the central nervous zysten of goldfish, irradiated in the defthe of a water phantom. Radiology 39(1): 92-95.

Eret, D. A. 1969. iffect of sublethal gamma irradiation on the iron netabolism of the pinfish. Lasodon rhonboider. pp. 152-156. In: symposiun on fadioecolof: (J. S. Welson and F. C. Evans, eds.). U. ... A.O report CCNr-670503.

$\therefore$ ncel, J. ., j. W. Angelovic and z. j.. Davis. 1965. ome effects of an acute dose of cobo gamna radiation on the blood of the pinfish, Lagodon rhomboides. (aostr.). Radiation kes. 25(1), 186.

تntel, D. i., J. A. Angelovic and E. in. Davis. 1966. iffecte of acute earma irradiation on the blood conEtituents of pinfich, Iagodon rhomboides. Chesapeake ijci. ?(I): 90-94.

jpstein, Ya. A. and N. F. Lavrovskaya. 1959. Effect of ionizing radiation on the protein metabolism of fich. Biokhimíya 24(4): 592-599. (English transl. pp. 549555). (NNA 14-12459).

srickson, R. C. 1970. iffects of tritiated water and other sources of ionizine radiation on mortality, growth, male characters, courtine behavior, and thermal death of Poecilia reticulata, the guppy. Thesis, Univ. of vashineton, seattle. $x 1,160 \mathrm{pp}$.

irickson, E. C. 1973. Effects of chronic irradiation by tritiated water on Foecilia reticulata, the guppy. 00. 1091-1099. In. Radionuclides in Ecosys tems. (D. J. ivelson, ed.). U. S. AEC report CONF-710501E2. (NSA 26-4837).

Lrnoknin, V. Ya, and s. F. Iuntyan. 1977. Sorne peculiarities of bioloey of Rutilus rutilus from a water-body with hiwher content of 905r and 137Cs. pp. 76-77. In: Radioecoloes of Animals. (k. i.l. Aleksaknin, ed.). "Nauka." l.oscow. (In Jussian).

'to, li. 1973. iffect of external irradiation on fich effe and enbryo. pp. 202-233. In: Kadioactivity and iiches. Contamination, Injuries, and Utilization. (N. Ekani, ed.). Koseisha hosei Kaku, Tokyo. (In vapanese) (NiLA 29-16005). 
Eto, K. 1973. Effect of internal irradiation on fisk. pp. 298-316. Int Radioactivity and Fiches. Conte.... ination, Injuries, and Utilization. (N. EEaril, ed.). koseisha kosei kakli, rokyo. (In japanese) (Nis 2 !$10474)$.

itoh, 11. 1963. The effect of $\boldsymbol{r}$-irradiation on the vil. io logical responees of the nerve-fielanoniore syctc: in Carassius carassius. Zool. .af. (Tokjo) $72(10): 277 \ldots$ 232. (In Japanese) (Niva of Japan 3(5): 01075).

Ltoh, it. 1965. Effect of rractionation of irradiate' $\vdots 2$. of co6o $\gamma$-rays on the fish, Cryzias latines. LOOI. liag. (Tokyo) $74(1): 29-30$. (In Japanese) (ivi 0 : Japan 4(3), 01829). (N,SA 19-21904).

Etoh, H. 1968. Changes in incorporation of $3_{i-t h y i d i m}$ into hematonnietic colls of goldfish followinf. x-irradiation. Dobutrueaku zusehi 77: 213-219. (In Japanese) (NA 23-20?81).

Ltoh, $H$. 1969. Changes in 3i-tinyludine incorporation into hematopoietic cells of goldfish durine recover, period from radiation injury. innot. 2001 . Jap. 142: 159-165. (NiA 24-144.34).

itoh, $H$, and $\mathrm{H}$. Lrani. 1963. Lffect of hypopingsectom and adienalectomy on the lentth of survival ti:le after $x$-irradiation in the coldfish, Carassiug alizici. . iroc. japan dcal. 39: 503-506. (itais 19-10609).

stoh, K. and N. Egani. 1963. Kesponses to $\mathrm{Na}^{\top}, \mathrm{J}^{+}$. atropine, and adrenaline of melanophores induced by $x$-irradiation in the fin of the coldfich caras i

stoh, ii. and N. LEami. 1965. Effect of temperature on curvival period of the fish (rizias latipes, followiri: irradiation with different $x$-ray doecs. Anrot. .001 . Japan 38: 114-121. (Nis 20-16236).

Etoh, 1., and N. Heami. 1967. Damage accumulation ani recovery in the rish uryias latipes exposed to fractionated or protracted radiction at ilf fer a: terseratures. radiation ses. 32(4): $384-091$. 
-toir, s. anci x. l'auchi. 1973. 1.ortality response of olcfieh after excosure to fast neutron: and kBi of fi:t neutrons for inhibition of hatchability in Lriaris enbrios. pp. 18-25. In: Firet Report on ancer therapy with Jigh Enerey Farticles and the utili ation of short lived hadionucliates in Diagnosiics . iational Institute of kadiolocical jciences, Civa, japan, report IVIRS-s-2. (In vapanece) (INSA $32-6 ́ 755)$.

scoi, Ii., i. Hodo-taguchi and ii. iaruyalia. 1968. Erfectr of $x$-irradiation of a part of the body on s.ortail $y$ rate and on histological changes in the roloish, Carasrius auratus. J. Radiation kes. $9(3 / 4): 1+2-151$. Tise $23-43864)$.

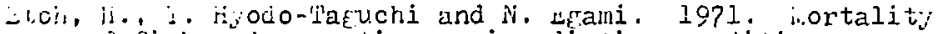
0 fish uncier continuous irraciation conditions. je. 213-212. In: Biological Aspects of kauiation froiection. (T. Sukahara, ed.). Igoku whoin, "rokyo. (CC:1:-61041). (INAA 25-42634).

a....j. $\cdots$ on . 1970. Investifation of fecundity and rowth of ilapia lossambica Feters after action by y-raje in errall doees. Thesis. A. $\dot{k}$. Zhdanov, Lcninerad state tniv., Leningrad. (In kussian).

ccercy, is. $\therefore, \forall$. it. Fodumakhin, iv. D. Whohiteniso and $\because \because$. Thumachento. 1964. Influence of weak radioactive contamination of the water on the developtient of Fleuronectes olatessa L. Voprosy Ikhtiol. 4 $(3(32)): 579-5,55$.

ieciorova, G. V. 1963. The effect of $\mathrm{sr} 90$ on Coregonus lavaretus ludofa errs and larvae. Vest. Ieningradsk. iniv. wer. Jiol. 1: $4 \mathrm{E}-53$. (BA 43-4255).

Feciorova, $G . V$. 1364. On the effect of $\mathrm{C}^{14}$ on developing: ova and larvae of freshwater fish. Voprosy Ikhtiol. 4. 723-72E. (English transl. JFRS-29452). (WSA 19$21: 263)$.

Leuorova, G.V. 1965. iffects of irradiation with ${ }^{60} \mathrm{co}$ on ewbrjonic and early post-embryonic developinent of Corekconus yeled. Nauchn. Dokl. VJssh. Shkoly (riol.) (2): Sil.-.

Indorova, G. V. 19úz. Lffect of ${ }^{14} \mathrm{C}$ on hatchine of whitefirh lalvae frola roe. Vestn. Ieningrad, Univ. (viol.) iv (21), 45-49. (In kuesian) (Nin 25-39907). 
Fedorova, C. V 1972. The biological effect of radiocarbon (Ci4) on fish in the early development stales. Voprosy Ikthiol. 12(1). (English transl. py. 173-177).

Feciorova, G. V. 1973. Biological effect of $14 \mathrm{c}$ incorporated in fish eges. Padiobiologiya 12(4): 56́-565. (jinglish transl. AliC-tr-7397). (Nis 27-17691).

Fedorova, G. V. 1977. On influence of ${ }^{14} \mathrm{C}$ upon respiration of freshwater fishes. pp. 91-92. In: Facioecolozy of Animals. (i. 1.. Áleksakinin, ed.). "iaulia., " i.oscow. (In kussian).

Feldt, $\mathrm{H}$. and $\mathrm{H}$. Buenringer. 1970. Damage to rish in the states of embrjonic and gonad development by ionizing radiation. Zentralbl. Veiorinaermed. Bein. (11): 4.2-50. (In German) (lise 25-24377).

Rield, F. Z., K. A. Lichtenheld and K. V. Kilambi. 1904. Effects of various photoperiods and colo tazs upon behavior of iteelhead trout. kesearch in Fisherics, 1963; Contribution 166. Univ, of dashineton Fresc. ieattle.

rollenius, $E$. 1952. infect of $x$-rays upon the evolution of the testicle and the appearance oi secondary sexuci characteristics in Lebietes reliculatus. Conot. Keni. Soc. Biol. 146: 1774-1776. (In French) (ives 7-4015).

Follenius, i. 1952. Frogress of ciereneration of the germinal cells in the adult male Lebistes reticulatur after $\boldsymbol{x}$-irradiation. Compl. Rend. Soc. Biol. 14o: 1776-1778. (In French) (NiSA 7-4019).

rollenius, E. 1963. Effect of $x$-rays on the nuclear. menbrane of sperinatocytes of lebistes reticulati!s. Ilectron nicroscope study compt. Rend. 257(13): 1982-1984. (In French) (IiSA Iह-1392).

Foster, R. $\vec{F}$. 1946. Sone effects of pile effluent vater on young chinook salmon and steelhead trout. lianford Atolic Products operation, General Electric Co.,

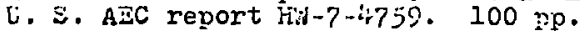

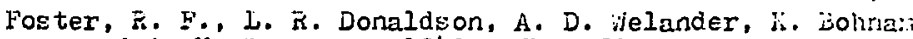
and $A$. It. ieymour. 19l\%g. The effect on embryos and young rainbow trout from exposing the parent fish to x-rays. Growth 13(2): 119-142. Sileo: iniv. of

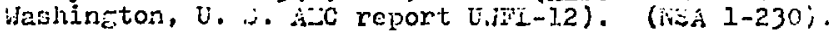


Frank, i.. L. 1971. Effects of acute ionizing radiation on carp (Cyprinus carpio I.) embryos. 'Thesis, univ. of 'iennessee, Ḱnoxville. Vi, $43 \mathrm{pp.} \mathrm{(Also:} \mathrm{i'rank,}$ 2... L. and B. C. Blavlock, Oitik Ride. Natl. Iab., U. $\therefore$. AEC report (RNL-T.-3346).

frank, i.. I. 1973. Sensitivity of carp (Cyprinus carpio) einbryos to acute gamma radiation. pp. 1106-1112. In: Radionuclides in Ecosystems. (D. J. Nelson, ed.). U. S. AEC report CONF-710501-F2. (NSA 2E30143 ).

Gimelfarb, F. B., R. N. Bogorad and G. ii. Ivanovskaya. 1972. Comments on radioecology of some freshwater fishes. pp. 104-108. In: liethods of Deternination of Radioactivity. (G. G. Folikarpov and V. F. Farachevskiy, eds.). "Naukova Dumka," Kiev. (In Russian).

Solovinskaya, K. A. and D. D. Ramashov. 1953. Effect of ionizins radiation on the development and reproduction of fishes. Vopr. Ikthiol. (11): 16-38.

Goodrich, H. B. and J. F. Firinkaus. 1939. 'ihe differential effect of radiations on hendelian phenotypes of the goldfish, Carassius auratus. Biol. Bull. 77(2): $192-199$.

Gorbman, A. and is. S. James. 1963. An exploratory study of radiation camage in the thyroids of coral reef fishes from the Eniwetok Atoll. pp. 385-399. In: Radioecology. (V. Jchultz and $A$. W. Klement, Jr., eds.). Reinhold Fublishing Corp., iNY.

vorodilov, Yu. N. 1971. Change in radioresistance of some species of salmon in the early stages of embryonal development. Kadiobiologiya 11(6): 930-934. (EnElish transl. AEC-tr-7307). (NSA 26-41160).

joss, j. A. 1955. The effect of $x$-raye on taste barbel regeneration in the catfish, Ameiurus. Am. J. Anat. o7 (1): 59-78.

Wrayevokiy, Ye. Ya., 2, N. Faleyeva and N. K. Flerova. 1966. Radioprotective effect of cysteamine under the action of ionizine radiation on loach sperm. Radiobiologiya 6(6): 886-890. (English transl. $A E C-t r-6775$ ). (NSA $21-36718$ ). 
Gros, C. M. and J. Bloch. 1957. Effect of temperature on the survival of the fish, Garascius carassius (i.) after total irradiation. Compt. Rend. Soc. Biol. $151(3)$ : 602-604.

Gros, C. L.., $\bar{R}$. Keiline and J. bloch. 1959. Radiation protective effects of cold in fish. تtrahlentierapie 109:241-245. (In Lerman) (Nial 13-17743).

Cros, C. i.., F. Keiline, J, Bloch and J. F. Vilän. 1958. Combined effects of cold and $x$-rays on fich. Radiobiol. Latina $1: 361 \cdot 375$. (In Italian) (ivis 13-17738).

Lros, C. hi, K. Feiline, j. Eloch and J. F. Vilain. 1958. iffect of $x$-rays on the survival of a fish (Carassiics carassius) exposed to low temperaturee, Conpt. irefid. ioc. Biol. 152(7): 11อ7-1190. (In French) (ivis 13 $7389)$.

Cunstrom, c. h. 1973. Lroce physical anomalies in 1 progeny of irradiated and unirradiated coho salvion. Prans. An. Fich. Loc. $102(2), 430-442$.

iue kova, v, N, et al. 1970. Lffects of a nixture of uraniun fiesion products on canitary conditions anc hyarooionte in bodies of weakly mineralized fresh water. Cidrobiol. 2h. 6(4). (Hydrobiol. J. $C(4)$ : 1-6). (scenedesmus glanciricauda. Infus oria, iotatoria. Earamecium caudatum, Levina minor, E. coli, white $1^{\prime \prime}: \dot{r}$ ani carp s pawn).

lagpquist, $G$. and $C$. Heves $y$. 1956. The combined effect of heavy water and roentren irradiation on the anifral organism. Acta Tadiologica 49(5): 321-325. (rish).

!iallapuchi. 3. 1976. Change in the radiation responser of oogonia in the embryos and fry of the fish Gryzias latipes. Intern. J. Radiat. Biol. 29(6): $565-570$.

ilataquchi, S. and N. Eqani. 1975. postirradiation chante: in oocyte populations in the fry of the fish oryis latipee. Intern. J. radiat. biol. $22(3): 279-264$. (A) 33-1745c).

liansen, H. J. I.. 1975. Chanees in the lipid fraction o: eel $\xi^{i l l s}$ arter ioni ine irradiation in vivo and a shift from fresh to :ea vater. kadiation ties. $62(2)$ : 216-224. (Aneuilla anguilia). 
iarada, Y.. ?. Ai and S. Kondo. 1959. Radiation effects on Fermcells of rainbow trout. (abstr.) (Fresented at 3 rd uapan Conference on Kadioisotopes). liatl. Inst. of Radiological science, Japan. I p. (JAIF, JFIA, 59/ $F-69, A-28)$.

liarrizon, F. I. and J. j. Koranda. 1973. I'ritiation of aquatic animals in an experimental freshwater pool. pp. 425-4;44. In: Radionuclides in icosystens. (j. J. Helson, ed.). U. ¿. GEC report CUNi-710501F1. (Nis 26-9424). (Clams, crayfish, Eolafish, cattails, filanentous algael.

heintz, E. 1958. Indirect chenotrophic action of 8 -rajs on the bitterline (hhoc zus amarus B.). Compt. hend. 21:6: 1309-1312. (In irench).

ielfrich, 1. 1960. A study of the possible relationship between radioactivity and toxiciti in fishes from the Central facific. Univ. of Hawaii, U. S. AEC report iLD-5748. $17 \mathrm{pp}$. (NSA 14-14962).

Hevesy. G. V., D. Lockner and $k$. Lletten. 1964. On the radiation censitivity of extranedullary hematopoiesis. wed. ilelt (10): 455.460. (In Gernan) (Nis 19-3937; 10-29957). (rish).

Hijiya, $i$ and $:$ Yagi. 1956. Effects of fiesion products upon development of aquatic animale. pp. 1219-1224. In: research in the Effects and Influences of the ivuclear Bomb T'est Explosions, Vol. II. Japan socicty for the Fromotion of science, Ueno, Tokyo. (knglish edition) (Daphnia pulex. Loina macrocopa, Pseudorasbora $\mathrm{p}$. parva, orvilas latipes).

iifgins, i. 1951. Atomic radiation hazards for fish. J. Wildife itgt. 15(1): 1-12. (NSA 5-2348).

iliurichs, i.. A. 1925. l.odification of development on the basis of differential susceptibility to radiation. 1. Fundulus heteroclitus and ultraviolet radiation. J. i.orphol. Fhysiol. 41(1): 239-265.

ilizhila, 'T, 1959. Iffect of $x$-ray irradiation on Gryzias latipes under different conditions. II. Sex difference of radio-eensitivity. Nippon Acta Radiol. 19 (1), 93-94. (In Japanese). 
Hiyama, Y. and F. Yasuda, 1954. BreedinE experiments with fishes in the extracts of "Bikini Ashes." Interim Report of the studies on the Effects of Radioactivity from the Fisheries Standpoints. (III): 77-81. (In Japanese).

Hiyama, Y., li. Shimizu and I. Suyama. 1970. Radiation effects on hatching fish errss. Report on the Influence of the Iow Concentrations of Radionuclides in Water to Aquatic Organisms. Nuclear Safety Research Association of Japan. (In Japanese).

HolzberE, is. and J. H. Schroeder. 1972. Behavioural mutagenesis in the convict cichlid fish, Gichlasoma nigrofasciatum Guenther. I. The reduction of male aggressiveness in the first post-irradiation generation. iJutat. Res. 16(3), 289-296. (NSA 26-59083).

Hyodo, Y. 1964. Effect of X-irradiation on the intestinai epithelium of the goldfish, Carassius auratus. I. Histological chanees in the intestine of irradiated fish. Annot. Z001. Japan 37: 104-111. (NSA 19-2085).

Kyodo, Y. 1965. Development of intestinal damage after $\mathrm{x}$-irradiation and $3 \mathrm{H}$-thymidine incorporation into intestinal epithelial cells of irradiated coldfish. Carassius auratus, at different temperatures. Radiation kes. 26(3): 383-394. (iNSA 20-5374).

Hyodo, $Y$. 1965. Wffect of $X$-irradiation on the intestinal epi thelium of the goldfish Carassius auratus. II. Influence of temperature on the development of histopathological changes in the intestine. Radiation Res. 24(1): 133-141. (NEA 19-10880).

Hyodo, $Y$. 1966. Effect of $X$-irradiation on phosphatase activity in the intestine of the goldfich, Carassiuc: auratug, at different temperatures. Annot. 2001 . Japan 39: 119-127. (NSA 21-24338).

Hyodo-Taguchi, Y. 1968. Rate of development of intestinal damage in the goldfish after $x$-irradiation and mucosal cell kinetics at different temperatures. pp. 120126. In: Gastrointestinal Radiation Injury. (ii. $F$. Sulilvan, ed.). Exerpta hedica Foundation, Amsterdam. (NSA 22-49540). (Carassius auratus). 
iyodo-fiacuchi, $\dddot{i}$. 1970. Effect of $x$-irradiation on Jif synthes is and cell proliferation in the intestinal epi thelial cells of Eoldfish at different temperaturcs with special reference to recovery process. Radiation Fes. $41(3)$; 568-578. (NiA 2L-19034).

jerocio-fanuchi, Y. and W. Egani. 1969. Chance in dosesurvival tiase relationship after $x$-irradiation during. elnoryonic development in the fish, oryias latipes. J. Kadiation Res. $10(3 / 4)$ : 121-125. (NAA 24-36818).

1. ocio-iaguchi, $Y$, and $N$. Egami. 1969. Development of intestinal radiation injury and recovery at different temperatures in fish. op. $244-254$. In: Comparativ:? Cellular and species Radiosensitivity. (V. F. Bond and 'i. sugahare, eds.). Jililiams and wilkins, saltimore, .j. (Viis 24-12291). (Goldfish, Cryzias latipes).

i, ocio-iaguchi, $Y$, and iv. igani. 1970. Inhibitory efíects of -rays iroll $90 \mathrm{Sr}$ - $90 \mathrm{Y}$ on gonad formation in enturyos of cryzias latipes. Dobutsufralsu Lasshi 79: 10́5-187. (In Japariese) TiNa 25-24379).

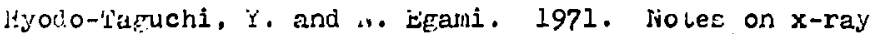
effects on the testis of the Eoby, Chasmichthys gulosus. Annot. 2001. Japan 44(1): $19-22$. (NSA 252.69927 .

ijodo-laguchi, $Y$. and $\mathrm{li}$. Leani. 1976. Wfiect of $\mathrm{x}$-irradiation on spernatogonia of the fish, oryzias latipes. radiation Fes. 67(2): 324-331.

tyodo-laguchi, $Y$. and N. LEami. 1977. Damage to spernatogenic cells in fish lkept in tritiated water. kadiation kes. $71(3), 641-652$. (Oryzias latipes).

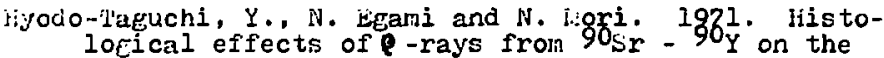
ovary of the marine Eoby, Chasmichthrs gulosus. J. lac. Sci., Univ. of Tokjo, Section IV 2001. 12: $337-$

¿yorio-Iaguchi, $1 ., \mathrm{H}$, Etoh and N. Egami. 1973. $\mathrm{KBE}$ for fast neutrons for inhibition of hatchability in fish embryos irradiated at different developmental staces. liadiation kes. 53(3): 385-391. (Cryzias latipes). 
Ichikawa, R. and I. Luyama. 1974, Effects of tritiated water on the embryonic development of marine fishes. Bull. Jap. soc, Fish. 40: 819- .

lchikawa, T, 1973. Cutline of radiation and biological effects. pp. 1-29. In: hadioactivity and lislee. Contamination, Injuries, and vtilization. (N. Lis alii, ed.). Koseisha Kosei Kalku, lokyo. (In Japanese) (NSA 29-16004).

Ickikawa, 'P.. I Suyama and $n$. lieno. 1973. Effect of radionuclides on the developtent of spawns. pp. 1-5. In: Investifations of the bffects of low Concentretions of Radionuclides on Aquatic Life. Nuclear Safety Research Assoc. T Tokyo. (In Japanese) (NSA 31-8977). (Killifish).

Ichikawa, T., K. Eto and N. Eyani. 1973. Radiation, ichthyology, and fisheries. pp. 30-64. In: Radioactivity and Fishes. Contanination, Injuries, and Utilization. (N. Egami, ed.). Koseisha Kosei Kaku, Pokyo. (In Japanese) (NSA 29-13027).

ljiri, K. 1977. Gamma-ray irradiation on primordial term cells in fish Grvzias latipes: vuantitative assessment of changes in nuclear size. J. Radiat. Kes. $18(4), 293-301$.

Ijiri, K. and $N$. Egami. 1977. Effects of $\gamma-\mathrm{raj}^{\prime}$ irradiation on primordial germ cells in embryos of cryzias latipes. Radiation kies. 72(1): 164-173.

Ijiri, K., F. N. Srivastava and N. Egami. 1978. A note on immediate mortality in the fish orvicias latipes after exposure to massive $\boldsymbol{\gamma}$-radiation. Intern. $J$. Radiat. Biol. 33(2): 201-203.

II'yenko, A. I. I969. Sadioecology of freshwater fishes. Vopr. Ikhtiol. 2(55). (Enflish tranel., Froblens of Ichthyolory $9(2): 249-260)$.

Ivanov, V. N. 1965. Radiosensitivity of the developinf effs of sea fishes. pp. 181-182. In: Froblems in liydrobioloey. l.oscow, Fubl. house Acad. Sci. Uisk. (In Russian).

Ivanov, V. N. 1965. wome features of radioecology of marine fishes in the early stages of ontogeny (an experimental study). itheeis for Defree of Candidate of Biological Sciences. Sevastopol. 197 go. (In Fussian). 
Ivanov, V. N. 1965. Variation in radiosensitivity of rish efrs during their development. Vopr. Gidrobiol. 1966: 181-182.

Ivanov, V. N. 1967. Effect of radioactive substances on the embryanic development of fish. pp. 185-190. In: Froblems in Biooceanocraphy. Reports of the 2nd International Oceanographic Congress, 30 Jiay 9 June, 1966. Kiev, Publ. House Acad. Sci. USSR. (CONF-660574). (English trans1. AEC-tr-6940). (iNSA 23-982.5; 23-26891).

Johncon, T. S., R. K. Nakatani and F. D. Conte. 1970. Influence of temperature and $x$-irradiation on the cellular dynamics of the intestinal epithelium in coho salmon. Oncorhynchus kisutch. Radiation Res. 42(1): 129-140. (INSA 24-25570).

iafiani, J. A., li, Ya. nimofeyeva, A. A. Neyfakh, Yu. A. Kachkus and $N$. I. lisel nikova. 1966. iffect of roentfen-ray irradiation on synthesis of information INA in the early embryogenesis of the loach. Biokhimiya 31: 365-371. (inflish transl. pp. 313-324). (NSA $21-22724)$.

iasatisina, $i$. $V$. 1971. iffect of $90_{\mathrm{Sr}}+{ }^{90} \mathrm{Y}$ on the development and functioning of the hatching glands in ftlantic salmon. Ir. Polyar. Nauch.-Issled. Frockt. Inst. liorsk. Ryb. lihoz. Okeanogr. (29): 55-61. (Enclish trans1. ALC-tr-74IE). (NSA 2728002).

iasatkina, S. V., V. V. Kosheleva, V. N. Higalovskaya, I. F. liigatpyskiy and S. A. Oganesyan. 1973. Chronic effect of $144 \mathrm{Ce}$ and $137 \mathrm{Cs}$ radioisotopes on embryonic development of the Atlantic salmon. pp. 25-35. In: iadioecolory of Vater OrEanisms. III. The Effects of Ionizine Radiation on later Organisms. (G. F. indrushaitis, ed.). Kiga, Izdatel'stvo Zinatne. (inglish trans 1. AEC-tr-7592). (NSA 30-24374; 31$11668)$.

riashivagi, li. and $H$. itoh. 1970. Histological and auto. diographical observations of the effects of $x-$ i.radiation on Eill epithelium of the Eoldfish. Carassius auratus. Annot. 2001. Japan 43(2): 93-101. (HIA 24-51033). 
Kas'yanov, $V$, I, and $N$. A. Lukina. 197l. Fffect of in the tissue of Atlantic salmon larvae. Ir. yolyar. Nauch.-Issled. Froekt. Inst. Worsk. Ryb. Khoz. Okeanogr. (29), 110-115. (English transl. AìC-tr7418). (NSA 27-27948).

kaufman, G. A. and K. J. Beyers. 1973. iffects of chronic Eamua irradiation on the fish, Oruzias latiges. $p$ p. 1119-1124. In: Radionuclides in icosystems. (i. $\mathrm{J}$. Nelson, ed.). U. S. AIC report CONF-710501-\$2. (NiA 28-30144).

Kessler, R. and W. Luther. 1957. Die dirkung der Kontgenstrahlen auf den Hoden und die sedundaren Geschlechtemerkmale von lebistes reticulatus Feters. Z. Vere. Fhysiol. $40(5):=492-528$.

Killebrew, R. and 2. Brou. 1965. Effects of 60co (Eanma radiation) on the melanophores of Gambusia affinis and hollienisia latipinna. J. f.iss. Acad. Sci. II: 197-204. (NSE 20-42905).

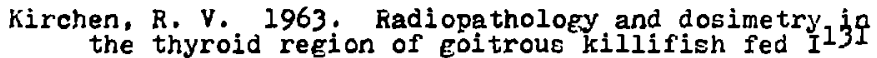
under euryhaline conditione (abstr.). Health fhys. 9(12): 1341 .

Kirpichnikov, V. S. 1961. Crowth and viability of carp marked with caicium -45 and influence of $45 \mathrm{Ca}$ marking on heredity. Izv. Cos. Nauchnr-Issled. Inst. Giern. i Rechn. Ryb. Khoz . 51; 255-265, 272. (NSA 19-36024).

Klyashtorin, L. B., I. A. Shekhanova and A. A. Yarzhornbek. 1972. Un influence of radioactive strontium on respiration rate of loach embryos. Tr. Vses. Nauchn.Issled. Inst. Sorsk. Kyb. Khoz. Okeanogr. (85), 27- .

Kobayashi, J. and I. Yamamoto. 1971. Effects of irradiation on spermatogenesis in the guppy, Lebistes reticulatus. Tokushina J. ixpti. bied. 10: 21-27. (NEA 27-534).

Lobayashi, s, and $\mathrm{H}$. hirata. 1957. Effects of $\mathrm{x}$-irradiation upon raintow trout (Salmo inideus). I. Influence on the feeding activity in rainbow trout fry. Bull. Fac. Fish. Jioklsaido lniv. 8(1): 23-35. 
1.0vageshi, . . and i.. nogani. 1958. Effects of x-irradiation upon rainbow trout (Salino iricicus). III. cvar: crovth in the 2 taces of fry and fingerling. sull. iac. Iish. ilokkaido Univ. 9(2): 89-94.

1.oilandiry, 1e. in. 1970. The use of ultraviolet radiation for the control of disease in efgs and fiches (the s.3i-3 compact bactericial plant). Vopr. Ikhtiol. 10(3). (cnrlish tranel. pp. 326-393).

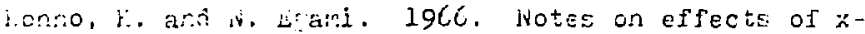
irradintion on the fertility of the male of civias liatipes (teleostei. Cyprincdontidae). Annot. Lool. Segan 39: C. 3-70. (HA 21-39509).

$\therefore$ sino, $\because$. $E \pm$ al. 1955. in the influence of $x$-ray radiaion on the aquatic animale. I. in the influence in the earli development of ici fisth (Carassiue

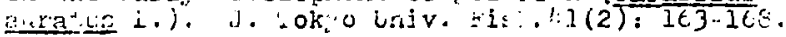

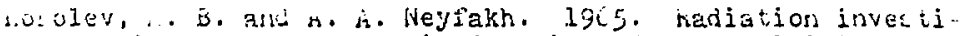
iation of rorphogenetic function of the nliclei in issue differentiation in early development of fist: enbryo (loach, i. iscurnus foesilis). zh. Ctehch. siol. 2i: $352-357$. (In สussian) (ivis 21-1799).

s, televa, V.. 1971. Accunulation of radioactive isotores $r$ the developin e: 2 of the Atlantic salion. 'r. Iolyar. lizuch.-Irsleủ iroets. lnet. orsk. ajb. ishoz. cheanos. (29): -15 . (Lnelirh

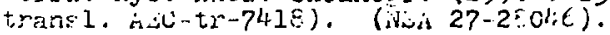

.ort.rleva, $v . V$. 1971. Chanfr in peripheral blooj in the enaryos and larvae of Atlantis salmon under the inflijence of redioactive contamination of the water and $x$ rars. jir. Holyar. Nauch. Issled. Frockt. inst. orsk. rybe dihoz. ckeanor $r$ (29): $(2-73$. (تni lish transil. AiLC-tr-7418). (W-4 27-2704C).

iotorin, $\therefore$. $\because$ anj is. $v$, jonteova $19(9$. investifation of the genetic apparatus of the sperr in iriurnus forsilig $W$ means of nonochronatic ultraviolet raliation. Genetika 5(7): 33-37. (In kuscian) (.....23-2515).

$\therefore \therefore .1 \mathrm{z}, i, \ldots$ 1956. Coservations on the fich populai ion of a lake contamirated by radiouctive vas la:.

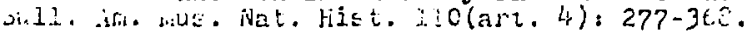


Liruriholz, I. A. and C. S. Shoup. 1953. Sumnary of papers on ecolopical effects of radioactive effluents. pp. 481-483. In: The Role of Atomic cinerey in AE ricul tural Research. Froc. Cak kidge jutner symposiuli-4th Ann. Symp. Oak Kidge, l'ennessee, 1952. U. ¿. AEC report TID-5115. (NSA E-2757).

Kukita, Y, and N. EFami. 1969. Effects of $x$-irradiation on rejection of transplanted scale in Eoldfish. Lobutsukaku Zasshi 78: 112-1i3. (In Japanese) (vì $23-41448)$.

Kulikov, N. V. 1970, Radiosensitivit; of roe of pike (dsox lucius 2.$)$ during fertilization and early cleavafe. hadiobjologiya 10: 768-770. (binglish transl. AEC-tr-7215). (NSA 25-29659).

Kulikov, N. V. 1970. kadiosensitivity of tench (Tinca tinca $L_{\text {. }}$ ) embryos at early stages of developnent. Kadiobiologija 10(1): 127-130. (english transl. ALCitr-7154). (NiA 24-27693).

kulikov, N. V., N. A. Himofeyeva and L. K. whishenkova. 1968. Radiosensitivity of developine tench embryo: (inca tinca 2.). Kadiobioloe iya $8(3)$ : 391-395. (Enclish transi. AlCi-tr-6916). (iNeA $22-51954$ ).

kulikov, N. V., N. A. l'imofeyeva and L. h. Al'shite. 1909. Decrease in the radiosensitivity of tench enbryos (linca tinca $L$. ) as a result of prelininary irradia. tion. kadiobiologiya 9(4): 637-639. (knglish trans. ALC-tr-7109). (NiEA 24-7999).

Lulikov, N. V., N. A. l'imofeyeva and L. K. Al'shits. 1970. Action of a previous irradiation upon the subsequent radiosensitivity of prelarvae of a tench ('inca inca L.). pp. 17- . Ini Action of Ionizing Radiations on Hydrobionts and Iand Flants. Trudy Instituta Ekologii kasteniy i zhivotnykh 74. (In Russian).

Lichtenheld, R. W. 1966. Effect of light, temperature, and gamma radiation on the locomoter activity of juvenile steelhead trout (Salmo Eairdneri). Thesis. Univ. of Washington, seattie. $254 \mathrm{pp}$. (NiA 22-255u).

Linn, D. U. 1962. The effects of radjum on certain g'oldifish blood constituents and reans. Dissertation. Utah itate Univ., Logan. $105 \mathrm{pp}$. 
Lockner, J., A. Fettersson and U. Ericson. 1972. Radiosensitivity of haemopoiesis in fish. II. studies ai 100 and $100 \mathrm{c}$. Intern. J. Kadiat. Biol. $21(\epsilon): 559-$ 572. (Nivi 26-41209). ('inca vulearis).

L.orz, i. ii. 1971. Effecte of $x$-irradiation, diethylstilbestrol, and size at time of release on the early Exual inaturation of coho salmon oncorhynchus kisutch. 'hesis. Creton state Univ., Corvallis. $102 \mathrm{pp}$. (Univ. wicrofilme Grder iNo. 71-25,068). (WSA 26$15+99)$.

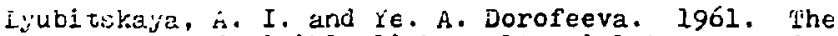
effect of vieible light, ultraviolet rays and temperalure on body metanerism in fish. 3. The effect of ul traviolet rays on the survival and body metamerism of (sinerus eperlanus eperlanus ( $I$.$) and Ferca fluvia-$ tilis l. vopr. Ikhtiol. 173). 497-499.

. oCandess, K. L., J. K. lioffert and F. O. Fromm. 1969. Lifht transmission by corneas, aqueous humor, and cryctalline lenses of fiches. Vision kes. 9: 223232. (iNis 23-43873). (UV irradiation).

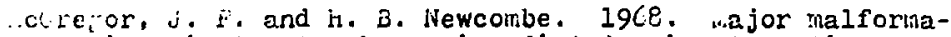
tion: in trout enbryos irradiated prior to active orkanogenesis. Radiation kes; $35(2): 282-300$. (NSA $22-45685$ ). (Salso gaironerij).

.cGlefor, J. I. and $H$. b. Newcombe. 1972. Decreaced riek of efibryo mortality following low doses of raciation to trout eperm. Fadiation Res. 52(3): 536-544. (ilimo sairdnarii).

scurefor, J. $\ddot{F}$ and if. B. Newcombe. 1972. Dose-response relationships for yields of major eye malformations followine low doses of radiation to trout sperm. Sacilation Res. 49(1): 155-169. (NSA 26-23116). (ialno gairdnerii).

, cilin, J. E., L. I. Christensen, J. H. Iucker, D. A. Benoit and i.. J. Lewie. 1974. Effects of pollution on freshater Iisil. J. Water Follut. Control Fed. 46(6): 1540-1591. (Hit 32-17564). (Includes ionizine radiation).

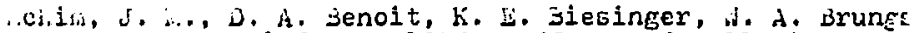
anci. $\div$. Niefert. 1975. Effects of pollution on irushwater fi:h. $s$, water Follut. Control F'ed. $47(0)$ : 1711-1768. (WA 33-20533). (Includes ionizing racila tion). 
1.ashneva, N. J. 1971. Liffect of complex mixtures of racioisotopes on developing. etgs of freshwater fici. after one-time contamination of water bodies. aif. sanit. 36: 118. . (In Kuseian).

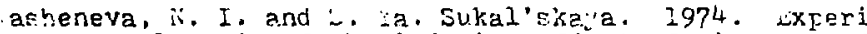
mental study of the jnjurinf effect of rixtures of fra mentary radionuclides in the emtronic development of freshwater fich depending on the assimilatec dose. pp. 49-55. In: Radioecolory of water Critrisms. III. The tffecte of Ionizin radiation on sater Creanisms. (G. F. Andrushaitis, ed.). (in lis trans1. ALC-tr-74+92). (NiN 30-24+376; 31-1It 70 ).

i:ichibata, H. 1976. The role of spermatof onia in the recovery process from temporary sterility induced by ganma-ray irradiation in the teleost oryzias latipes. J. Kadiat. Ree. 17(3): 142-153.

iifalovekaya, v. ii. 1971. Chronic eflect of $90 \mathrm{Nr}+96 \mathrm{Y}$ on the frequency of chromosomal aierrations in the embryonal cells of the Atlanif saltoot. ir. Folsar. Nauch.-Iseled. froekt. Iret. l.orek. @t. hitoz,

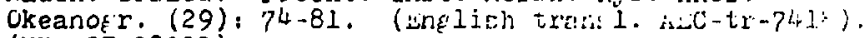
(NEA 27-28003).

. ikfalovskaya, V. N. 1971. iffeci of $x$-inmadiation on the ganetes and embryonal cells: of the stlentic salkon. i'r. Folyar. Wauch. -Iesled. broekt. Inst. worck. ini. Whoz. Okeanogr, (29): 82-90. (Enlish tranel. AtCtr-7418). (ivis 27-27947).

$\therefore$ ifralovskiy, I. F. 19?l. Development of Atlantic salmon eefes under conditions of radipactive contamiration of water by $90 \mathrm{Sr}-90 \mathrm{Y}$ and $144 \mathrm{Ce}$. 'Ir. Lolyar. iduch..Issled. Froekt. Inst. liorsk. Kyb. Khoz. Ckeanofr. (29), 16-27. (Enelish transl. AEC-tr-7418). (Ai 27-27999).

Mispalovskiy, I. F. 1971. Development of fish egts and the early period of cametogenesis in the em:bryos ano larvae of the Atlantic salmon under conditions: of radioactive contanination of water. Iir. Foljar. ijaucn. Issled. Iroekt. Inst. worsk. Kub. Hnoz. Gkeanofr. (29). 32-44. (Linglien transi. soc-tr-7418). (Nos $28001\}$. 
1.ikari, Y., I. datenabe and k. Takano. 1956. 'ithe influence o: radioactive rain-water on the Erowth and i.ifereniation of a tropical fish "Zebra Janio." if. 1225-1229. In: Recearch in the effects and influences of the Huclear Bomb i'est ixplosions, Vol. II. japan ociety for the Fromotion of -cience, iseno. iosio. (inglieh edition).

. oiscyento, Ye. $r$. 1964 . Action of $x$-rajs on desoxyribonucleo grotain of isgurnus fossilis sperm. nadio-

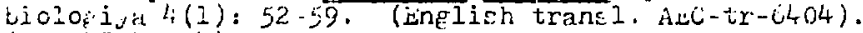
$($ i.t. $\quad 27-17574)$.

oiseycrko, tc. $\ddot{v}$. 196t. frimary danare and enzymatic incomposition of loach sperm and i. coli deoxyribonuclcoprotein under the action of radiation. Candicate's ciceertation. „oscow. (In kussian).

... kalkova, i., I. 1970. On, development of Neosobius alanos com iall. in radioactive cnlcium solutione.

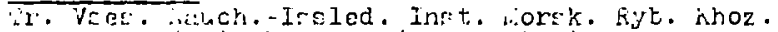
uevno:r. (ug): 40. . (In liussian).

. orl:al tova, 1. I. 1978. The influence of radioactive carbon $\mathrm{C}^{-1}$ on the cievelopment of the eqgs of the round rob: Weorobius melanostornus. Vopr. Ikhtic?. 1P(1). (inglich tranci. pp. 157-16I).

.urt.as. ... 1. 2977. un ruproduction of pike and perch in af experifiental water-body with hicher content of $70_{S \mathrm{r}}$ and $137 \mathrm{Cs}$. pp. 22-83. In: Radioecoloey of tinirrale. (h. .... Alekeakhín, ed.). "Nauka," i.oscow. (In russian).

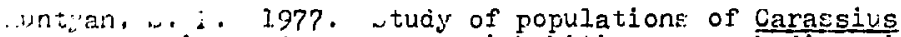
carac -ius and $\underline{L}$. auratus inhabitina water-bodies with alicher concentration of $90 \mathrm{sr}$. pp. 81-82. In: arijoecolory of animale. ( $\bar{k}$. i... Aleksakhin, ed.). "hakka," i.oscon. (In fiuksian).

iffeh: 1.. 19lth, 'the influence of radiation upon fich efre. (1) 'the influence of $\mathrm{r}_{\mathrm{Cl}} \mathrm{l}$ upon the heart of an enuryo which has been kept under radiation of $x-r$-res. 2001. .af. ("ioko) 56(8): 5-7. (ln Japanesej.

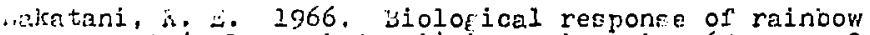
trout, (alno rairdneri) infesting zinc-65. pp. E0922. In: Jisposal of radioactive wastes into weas, Lcean: an! ..urface watere. Intern. atomic inergy SFency, Vienna, sustria, nublication $\because I / \mathrm{IU} / 126$. 
ilakatani, $K$. is. and $\pi$. F joster. 1963. sffeot of chronis: feedine of $\mathrm{ir} 90$.. Y90 on rainbow trout. pF. 359-3ć. In: hadioecology. (V. ichultz and $A$. W. hilesent, Jr., eds..). Rieinhold Fublishing Corp., Nir.

liatali, $V . F$. 1940. 'The effect of $x$-rays on the $s \in x$ gland of male lebistes reticujatus. Lch. Zap. bork., Gor Fed. Inst. (1): 5-29.

diatali, V. F. 1942. Changes induced in the ovaries of fishes (Foecilidae) by $x$.rays in relation to the problen of change of sex. Eylili. ciseper. eiol. t.ed. (10): $57-51$.

Natali, $\forall . \vec{F}$ 1942. The effect of $x$-rays on the sex riand of female lebistes rejiculatus. Eyull. eksper. Eiol. i.ed. $5(6): 56-59$.

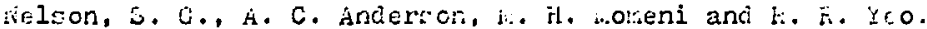
1976. Attentied sterilizalion of sexually undiffertitiated fry of Ijlapia zilli by 60 co zama-ray irradition. Fros. Fish-CuIt. 32(3): 131\%34. (whA 2-52977).

iseuhold, J. lit. and $\mathrm{k}$. $\mathrm{F}$. Sharia, 1969. Interactinf effects 5. ganma lediation a:k sodiun halide coneeritrations on rainbon trout. ip. 142-151. In: wi:posium or radioccology. (j. u. Nelson and l. C. tian:. eds.). U. S. nLC regort CUNA-670503. (ivis 2l-l.jlige).

Neustroyev, G. V. and V. iv. Fooytakhin. 1966. Levelonmental rate of Atlantic salinon (uluo salar) $\epsilon$ : $E$ when there is radiouctive contanination of the waick by :590 - Y90. Kadiobiologiya 6(2): 321-323.

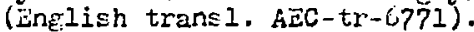

Neustroyev, $G$. V. and $V$. H. Foaymakhin. 1966, nespiratio: of ealmo salar eegs when there is radioacive contai.. ination of the water. Fiadiobiologiya 6(1): 115-116. (inglish transl. A $2 C-i r-6770)$. (NSA 20-42E20).

Neuetroyev, G. V.. V. G. Kondratenko and A. :. Kuzirh. 1967. Effect of trame radiation and radictoxine or the systhesis of DNA in car 3 . embryorrenes is of the ground] ing t.isturnis i'ossiliw. Izv. ibirsk. vit. skad. Nauk Sot (biol. mec.) (5): 95-99. (in nus sian); (HSA $22-23433$ ). 
lioustroyev, G. V., V. G. hondratenko and A. M. Kuzin. 1968. Influence of AET on loach embryos, liigeurnus fossilis, under the action of eamma-rays and radiotoxins. Radiobiologiya 8: 588-593. (English transl. AivC-tr-7014), (INSA 23-86I).

Hewcorsbe, H. E. 1973. "Benefit" and "harm" for exposure of vertebrate spern to low doses of ionizine radiation. Ilealth Fhys. 25(2): 105-107. (Salmo gairdnerii).

Newcombe, li. B. and J. F. j.cGrearor. 1967. hajor concenital malformations from irradiations of sperm and eEES. isutat. Res, 4: 663-673. (NSA 22-15072).

(Salmo gairanerii).

Newcombe, HI, B. and J. F, licGregor, 1972. Increased embryo production followine low doses of radiation to trout spermatozoa. Radiation Res. $51(2)$ : 402-409. (SzImo gairdnerii).

ileyfakh, A. A. 1956. iffects of ionizing radiation on the sex cells of kisgumue fosisilis. Doklady Akad. Nauk SSER $111(3)$ : 585-588. (NSA 11-3657).

ieyfakh, A. A. 1956. 'ihe changes of radiosensitivity in the course of rertilization in the loach iriseurnus fossilis. Dokladj Akad. Nauk SSSR 109(5): 943-946.

Weyfath, A. A. 1959. The effect of ionizing radiation on the early development of rishes. Tr. Inst. liorfol. Zhivot. (24): 135-159.

Vieyfakh, A. A. 1959. X-raj inactivation of nuclei as a method for studying their function in the early development of Iishes. J. Imbryol. Exptl. Horphol. $7(2)$ : $173-192$.

Neyfalch, A. A. 1961. Radiation inactivation of cell nuclei as the method of study of their role in the development of respiration in fish embryos. Biochemistry (USSR) (Bnelish transl.) 25: 503-511. (NSA 15-12735).

Theyfakh, A. A. and N. N. Rott. 1958. A study of the radiation injuries in fish and in early development staees. Doklady Akad. Nauk SSSR 119(2): 261-264. (inglish transl. pp. 134-137). (NSA 12-11240). (iiseurnus fossilis, Acipenser stellatus). 


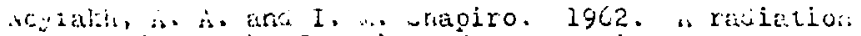
ratuc? ot tire furacion of coc, ies in lice proces: bi

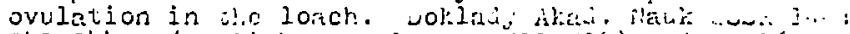

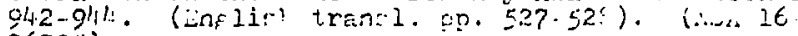
$26795)$.

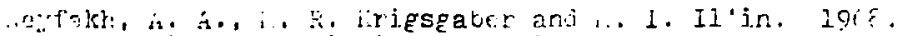

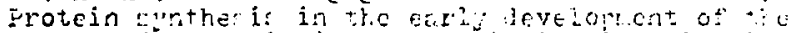

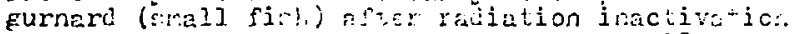

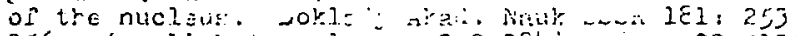
256. (an lj: ? t2an: 1. 7. 3 2-3Eli) (wan 22-513:3i.

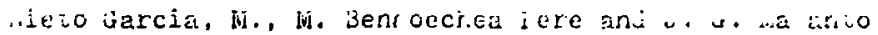
cernantez. 1975. Lifect of acclinalion letperathit on proliferetion oi erj thopoietic preclireore in

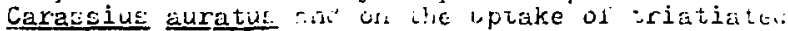

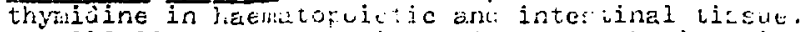

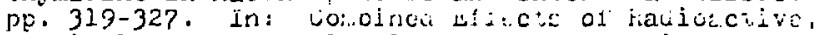

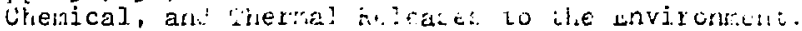

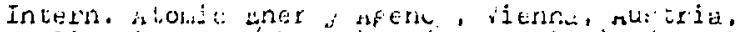

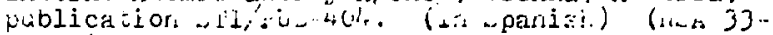
$29795 j$.

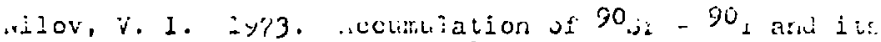

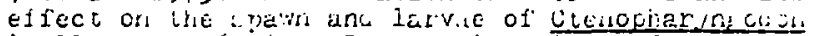

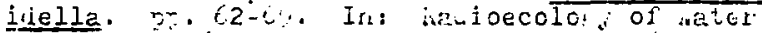

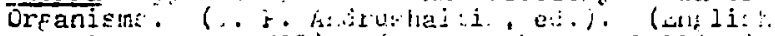

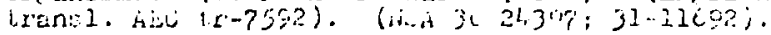

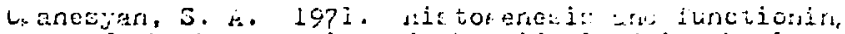

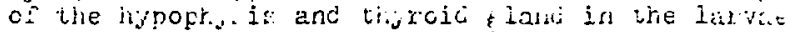

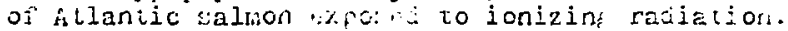

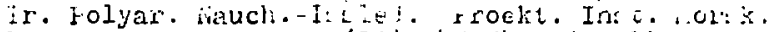

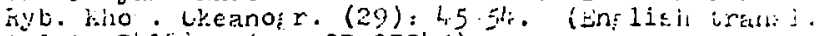
$\therefore \Delta C-t r-7 l i 16 ; . \quad(: \cdots .27-27945)$.

Ltaja, I., I. Cakave, : t.ikuchi anj i. sonno. Isk. Co the influence of $\gamma-r_{a j}$ radiation on the aiduidic anials. in lide inflicnce in the early develoftio:.:

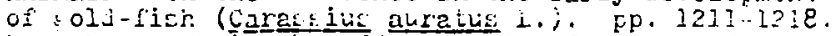
in: restearci in the tfecis and lifluence: of :ic

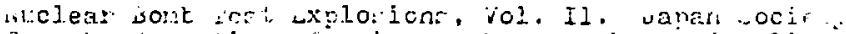

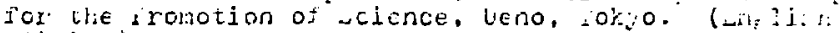
aisition).

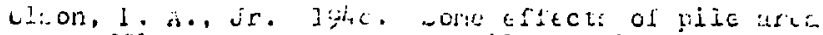

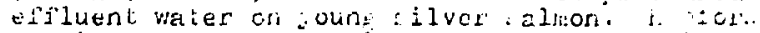

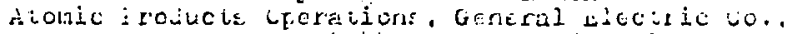

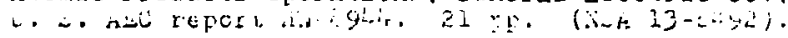


Crletel, I. I. and $j$. .... Judd. 1966. Effects of internal1 Jeocitej radionuclides on the thermel tolerance of rish. pF. $225-833$. In: Disposal of ravioactive .ai: ies into jeas, cceans and surface vatere. Incern. A tomic snerey Afcncy, Vienna, Austria, publicaion -II, IUII2C. (NA 20-3102E).

Lppelarin, h. 2914. vevelownent of trout eहE! $=$ ali.:

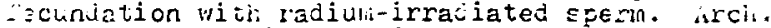
. ikx. Anat. $63(4)$ : 14i-189, fl:. 5-7. Also: sentr. Biochein. in siophys. 15: 90c-. (In Lelimeri)

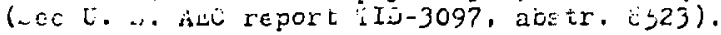

4. Werann, i.. 1915. jevelopnent of trout eqfe aliter il:prefation with radiula-irradiated eperí. Il. chavior of the ratiuti-chromatin Juring first atafes $0 \hat{i}=e$ sentation. Arch. .ikr. anat. $\hat{c} 3(4): 307-323$.

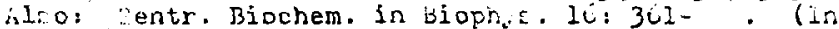

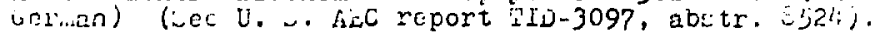

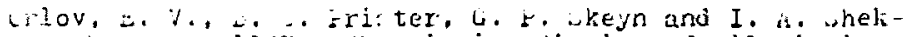
hovn. lgi\%. Chronic irratiation of tilapia in Col olution: ari its bioloeical corsequences.

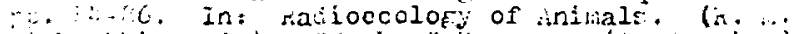
... eltrakhin, cd.). "iauka," lioscow. (in klifeian).

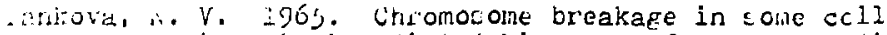
- encration. in irradialed pisfurnue fetlises. sivio

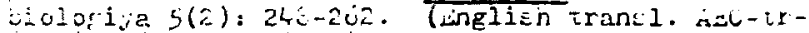
i599). (in.s. 10.2(2.075).

LCCHuventov, V. L. 197C. nise of chromosolal aderteiton: of isturnue ias ili. 1 . larvae develonin in ine 90.5 - or rolutiont of various activity. Lreita o(10): 67-7ü. (In kussian) (fis $25-10653$ ).

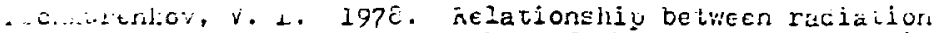
- O. ar c, du: e rate anc number or aberrant anajlase: in

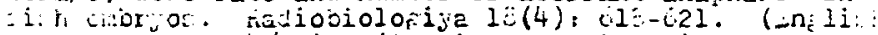

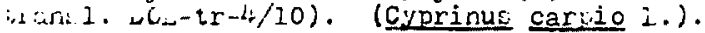

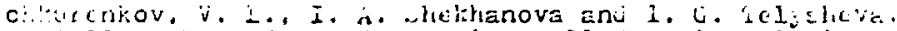
-22. Tie clfect of chronic stall does irraciction

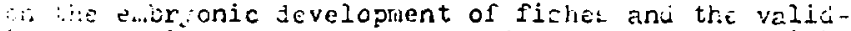

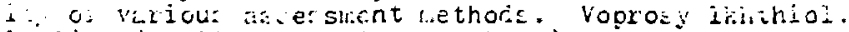

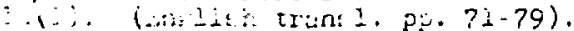




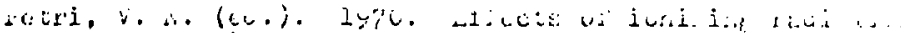

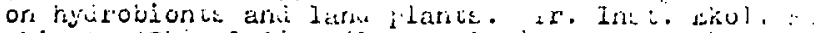
Zlivot. (74): 1-9i. (in aus: jan) (1, 2.

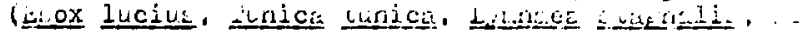

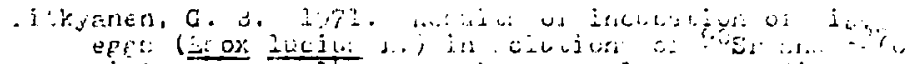
epes (

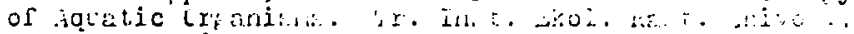
Everillovsk $7 \%$. (In rit..itin).

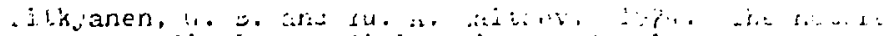

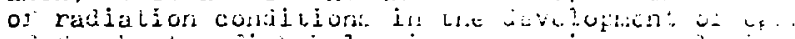

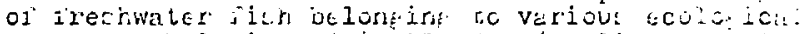

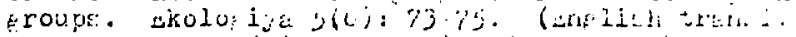

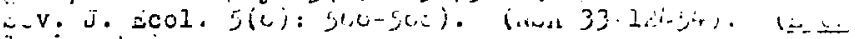
Iucius Li.j.

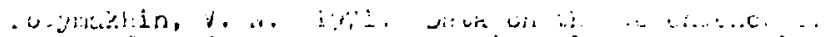

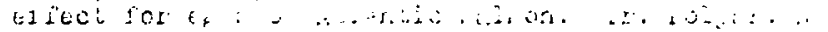

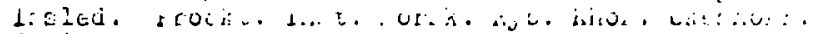

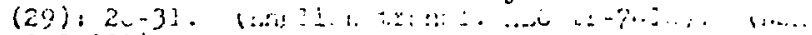
$27 \cdot 20000)$.

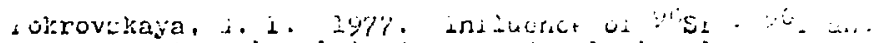

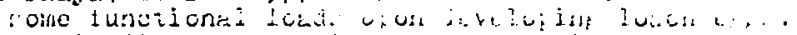

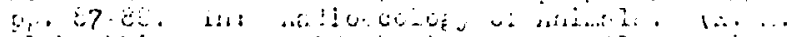

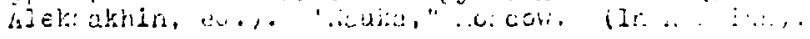

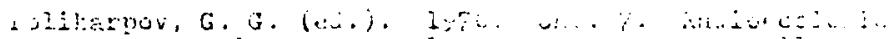

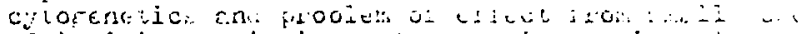

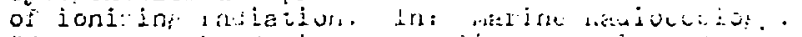

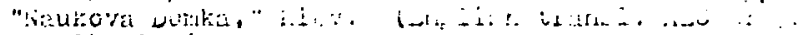
?:. $9: 173 i$.

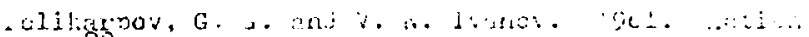

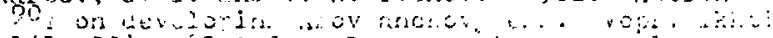

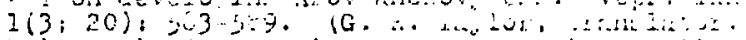

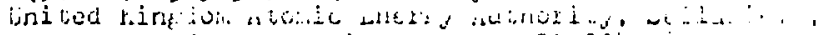

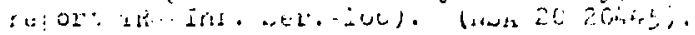

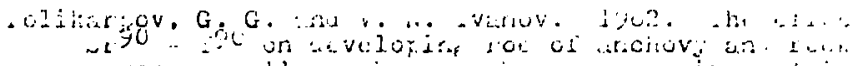

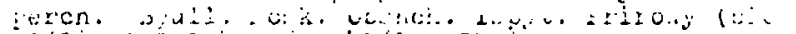

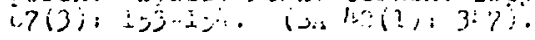




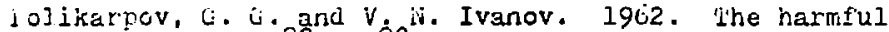
exiect of $5 r 90$ - Y90 on the early development perio: of .,Ulius barbatus ponticue, the hybrid crenilabrus tinca $X C$. quinqueinaculatus, Irachurus and Entraulis encrasicholus. joklady Akad. Nauk jisR 144 (Biol. :ci.): 219-222. (inglish tranel. pp. 491-494). (ivi $16-26792)$.

forte, A., J. F. Zahnd and A. Batzenschldeer. 1963. lihe ultractricture aspecte of the liver in Lacerta Sirjius aru sccara lati irons azter intraperitoneal injection oi thorium dioxide ('horotrast). Lompt. Fend. Loc. Diol. 157: 1791-1795. (In French) (iHSA 18-250úó). (Lizard, t゙ish).

rrasilna, in. 1905. Behaviour of tish in the zone of radiation iources. Byull. Ekcper, siol. bed. bo(il):

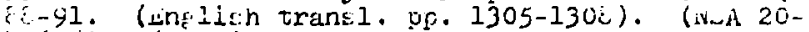
Hoc 50 ). (carts).

Eravoina, G. A. 1960. Behavior of rish in a radiation zone. pp. 97-103. In troblens of veneral kato

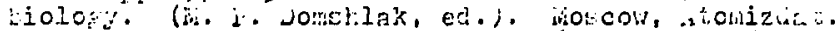

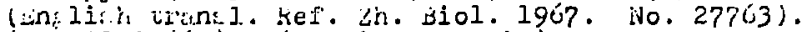
(4w.2 $22-23663)$ (Cjorinus caroio).

arecton, s. 1959. Leucocytosis in response to bactcr. athia as a lieature of the acute raciation suaroite in ihe plaice. Nature 163(4664): E32-£33.

areson, $\therefore$. 197l:. radioactivity in the tarine environ..tni. pp. 305-329. In: Sea iticherief jecearch. (.. I. Hinxuen Jones, Ga.). John wile, anó uoni, di. (includes esecte on $i:=h)$.

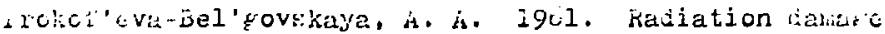
ic chromoscines at carly develoment etafes oi intuon. i:itologiva $3(4):$ - .

rols:" eva-ul'rovskaya, A. A. and iv. V. Fankova. 1965. Jifierratial dainage of the varental chromoconal conlusente following irradiation. zoklasy hked.

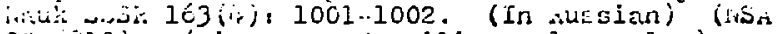

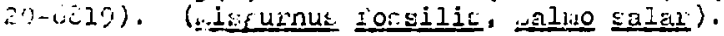

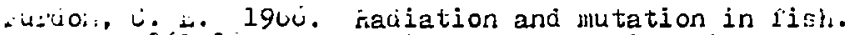

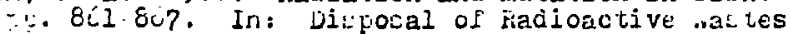

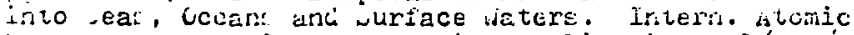

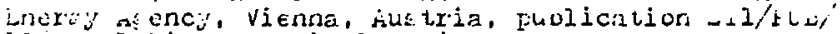
ize. In: i. Lli: reticulatus). 


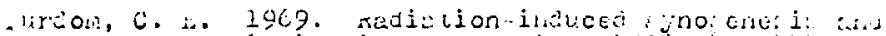

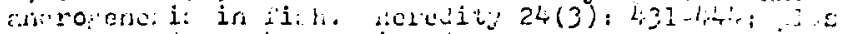

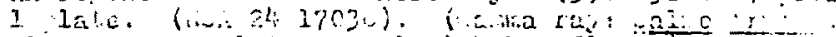

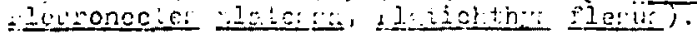

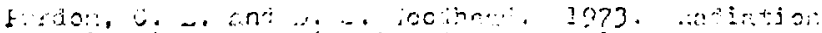

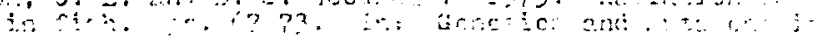

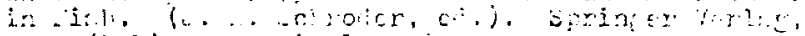

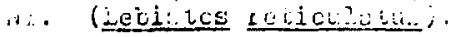

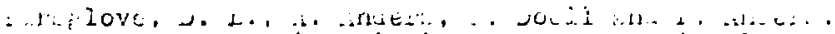

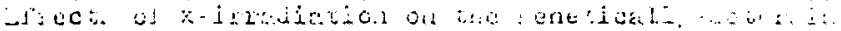

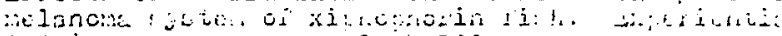

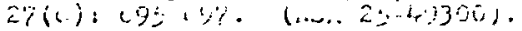

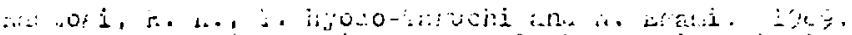

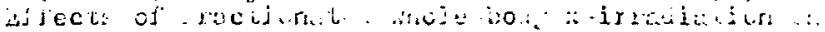
ccil !

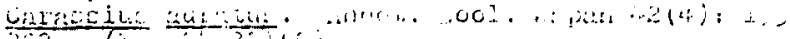

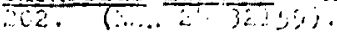

$\therefore$ ri.

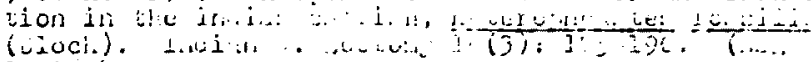
$30.3+i)$

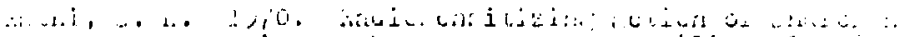

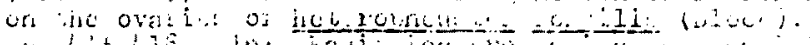

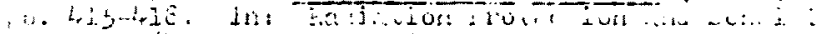

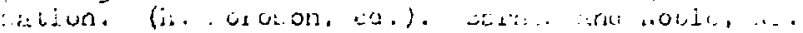

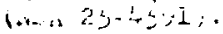

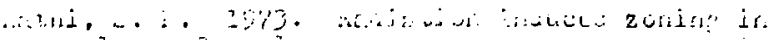

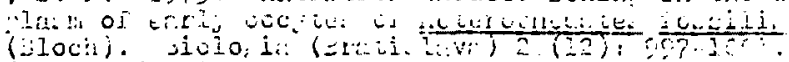
$(\therefore i s+1+342)$.

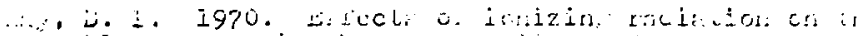

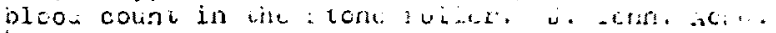
i, : 2 :

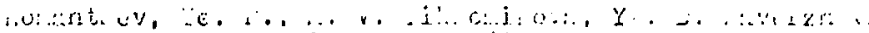

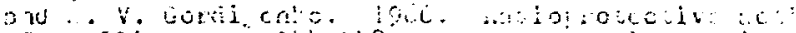

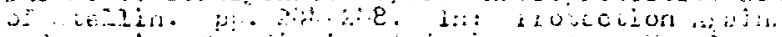

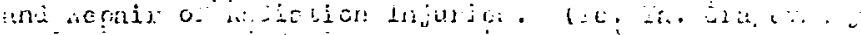

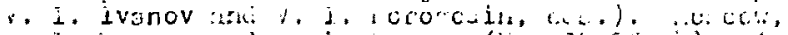

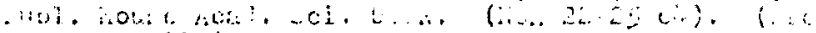
itilgeon ailij. 
romashov, D. D. and h. A. Golovinekaya. 1960. Racliation biolocy and the genetics of fishes. pp. 9-49. In the series, Frogrese in science. (Biological sciences). ilo. 3. Ionizing Fiadiation and Heredity. (li. $\hat{r}$. Dubinin, ed.). lioscow, Acad. Sci. U'sir. (In hussian).

roinashov, D. D. and V. N. Belyareva. 1964. The cytolocy 0 the radiation Eynogenesis and androgenesis in 1. ikcurnue forsilie L. Doklady Akad. Nauk S'sS 157 (4) : $964-967$. (Englieh trans 1. pp. 503-506). (ivi $(0-2102)$.

Eonachov, D. D. and $V$. W. Belyajeva. 1965. Sadiosensitivity of loach (i. is gurnus fossilis L.) eggis. Genetika (5): 101-109. (In kursian) (W\$A 20-24r.94).

. onat hov, J. J. and $V$. li. Belyayeva. 1966. Conetancy of radiation-damaced chromosomes in fish embryogenesis. (enetika (4): 4-15. (In kursian) (riwa 20-35270).

Koriarlov, D. J., V. N. Belyayeva, $\dddot{n}$. Golovins kaya anc A. A. Frokof'yeva-del' covikaya. 1960. Radiation damage in fish. Akad. Waul $\mathrm{Gsk}$, i.oscow. $10 \mathrm{pp}$.

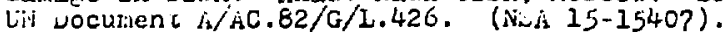

Joliaklov, D. D., W. I. Wikolyukin, V. W. Belyayeva and ii. is. Tinorejeva. 1963. Gynorenesis in sturgeon itil obtained oy means of irradiation. Radiobiolosiya 3(1): 104-110. (U. $a$. ALC tranel. AEC-tr-54:3lr). (.

Soinachov, D. D., V. H. Belyajeva, K. A. Golovinskaya anci a. is. Erokor'yeva-Bel'Eovekaya. 1963. kadiation injiries in fish. Enelish sbsts. Soviet eloc ans ainlane thina iech. Jour. Wer. VI, Bio-sci. i2-11, $1: 5(26):$ n.p. (abstr. only). (SA 45(9): 36107).

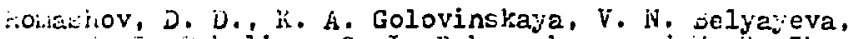
1. 5. Sakulina, G. I. Pokrovskaya and ii. B. Cherfas. 13úl. Jiploid radiation ejnocenesis in $\mathrm{fish}$. vioii: ika $5(4)$ : l, El-4C?. (inglish transl. pp. 524-532). $(\therefore . \therefore 15 \cdot 15430)$.

..ot, \#. it. 1959. The effect of colchicine upon irradiated

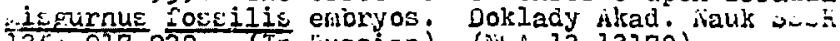
I25: $917-920$. (In Hussian) (NiA 13-13170). 


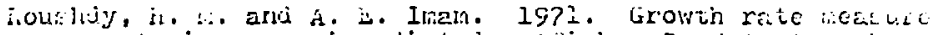

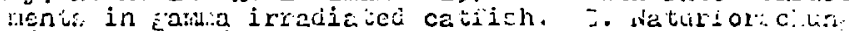

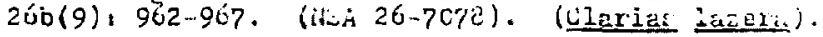

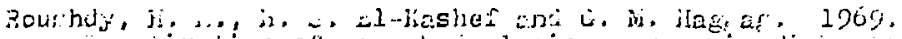

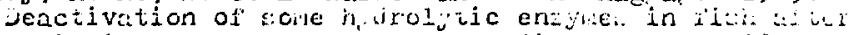

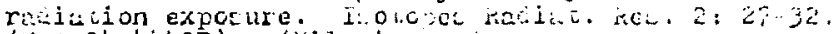

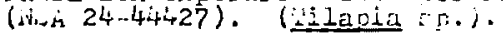

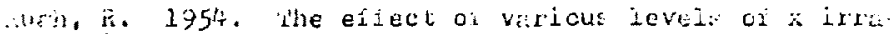

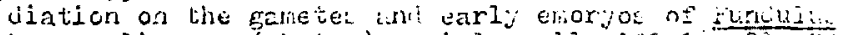

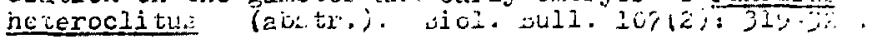

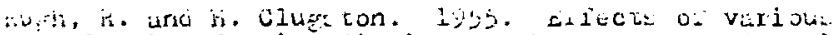
levels: of $x$-irrabletion on ti.e caite ie: arid dirly anoryos o! zuncilui heleroclitue. Jiol. Wui. io. (3): $316-3 x^{2} \cdot$

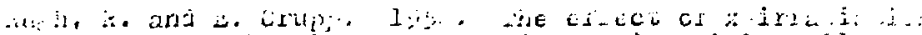

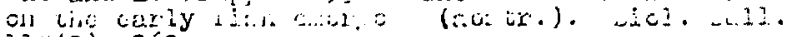
$125(2): 302$.

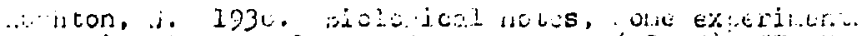

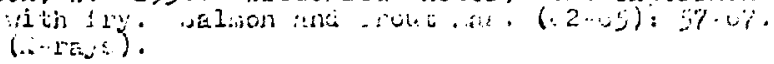

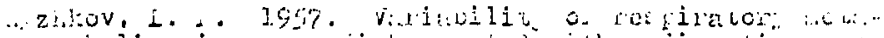

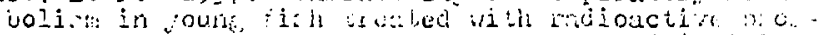

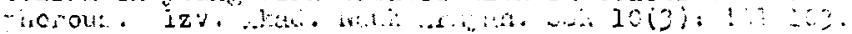

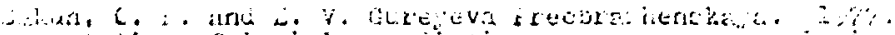
inction of ionizin raitation on procese os theitic

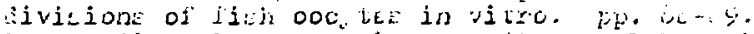

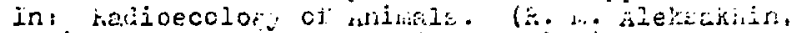

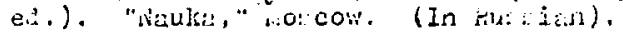

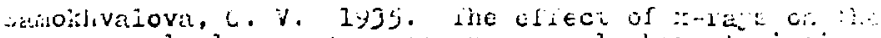

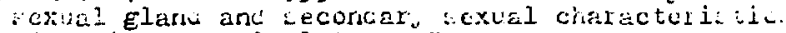
ci ielictes retigulatus. In: vorst on Growh

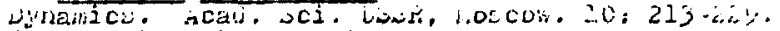

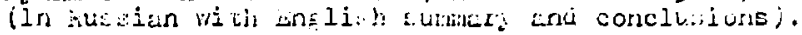

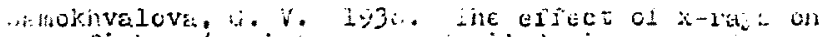

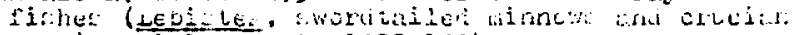

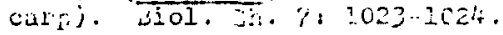

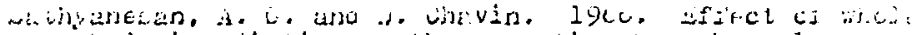

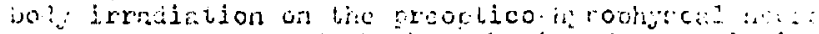

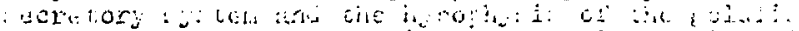

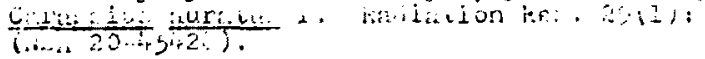


.ethyancsar, $\hat{A} . G$, and $W$ Chavin, 1966. Lffecte of wholebodi irradiation on the adrenal of the golcifist Caraseiue auratus 1 . radiation hes. $23(2): 352-304$. (iisi2 20..3 1094$)$.

sithitanelan, H. G. and S. A. arivastava. 1970. kaciioiodine incuced throid tuinours in tre Inilen ireshwater cat-fish ctus vittatus (jloch). Current ici. (India) 39: 350-351. (ivis 24-litjón).

crivolough, j. Z. and s. G. Addison. 19i2. Conuitionin in fisin: wiects of $x$ irratiation. Science $130(3517): 712-713$.

-chmidt-Loren:,, and $j$. itarkas. 1961. Studies on the radiation resistance oi sone ls chrophilac bacteria and veaste of marine fishes. arch. tikrobiol. 39: 1-12. (it. A 17-24909).

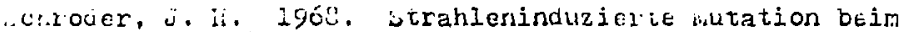
Gippi, lebi. tes reticulatue feters. Verh. Dteci. 3001. Ges. (Heidelber's) 2001. An: 31 (suppl.): tiól-

chroier, i. di. 1969. Die Variavilitat quantitativer terlimale bei Lebijtes reticliatus ieters, nach ancestraler sontgenbestrahlune. Zool. Beitr. W. F. 15: $237-265$.

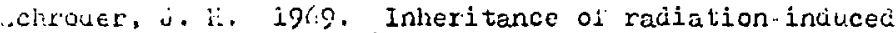
irinal curvatures in the guppy iebietes reticulatus. can. i. Cienet. Cytol. 11: 937977 . (iwis 24-2315E).

Sciroler, $j$.H. 1969. wantitative chanfer in oreciline (roups of jebictes after irradiation. Can. j. Lenci. i, tol. 21 , $955-960$. (iva 25-21650).

- cirocier, i. Hi. 10ú. riaulation-induced apernatozonia exchane between the $x$ and $y$ chronoromes in the suppy. Lan. J. Genet. Cytol. 11: 948-954. (iisi 24-23100\%.

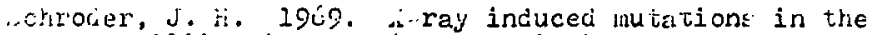
poeciliic rish, Iebietes reticulatus olers. ..urat. lies. 7: 75-90. (1ind 23-22259).

.chrocer, u. F. 1973. Feleasts as a tool in mutation research. pl. 991-995. In: Genetice and whtacen. eili of ish. (j, l., wchrader, ed.). wprinterVerlat, Hi. 
-chrouer, $\therefore$. 11. and $\alpha$ rol: ber.j 1972. sopulation anc tics of iebistes (ioeciliä) reticulatus $j \in t \in r$

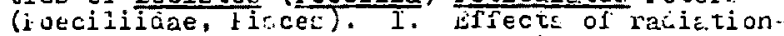
incuced mutations on the cefregation ratio in yo: 5 irradiation $i^{\prime} 2$. Genetics $70\{4\}$ : $021-630$. (Nim 20 -

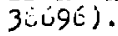

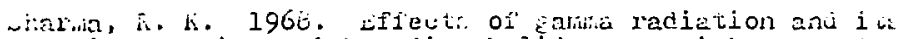
interactions with sodiun helides on reinbow trout.

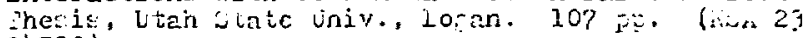
$24730)$.

whecheister, I. I., L. $\therefore$. iatron, $V ., i$ cole and L. $i$. jackron. 19t2. The effect of z-irradiation on roletish. i. He effect of $x$-irrailation on sur.

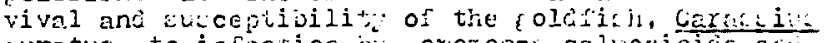

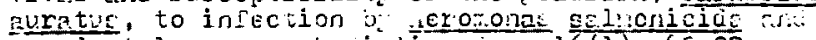

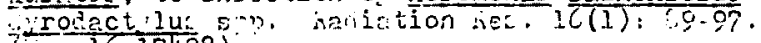
$(1, \ldots, i)-1(-7498)$.

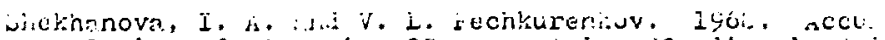

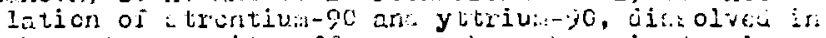

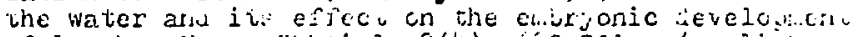

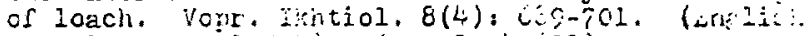
irin:1. $\left.F_{1} \cdot 551, j, 1\right)$. (1w.: $35-40093 ;$.

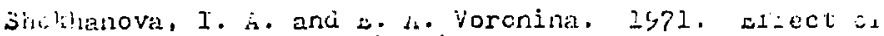
racioactive contanination of the water on regreciucios

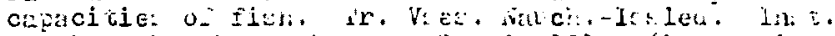

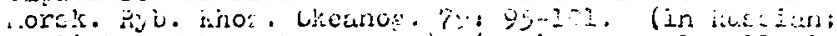

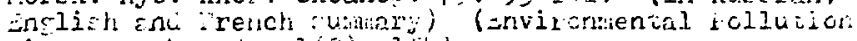
jiorec earch $\left.\operatorname{codaj} 1(j): 1 y^{4}\right)$.

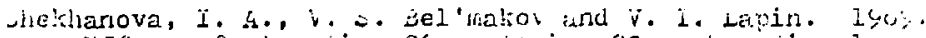
تffect of strontium 99 yteriun-90 on ureeding lect.

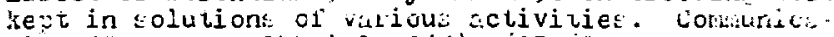
tion 1î. Vopr. Ikhtiol. $9(5)$ : $227-435$.

Shekhanove. I, A., G. i. gialeyicr, i. S. Jilyshtorin arm N. G. itoroziuk. igoi. Inetructions on estimivior or raciation influence upon respiration irten: íj. $i_{i}$ alunolorical reaciviz anc corsent of lipid hycre.

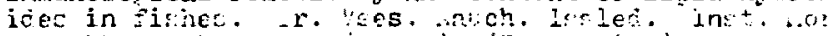

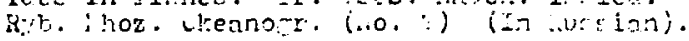

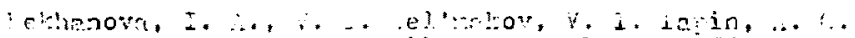

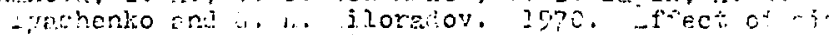

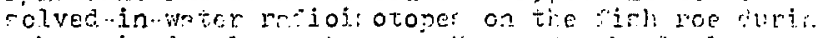

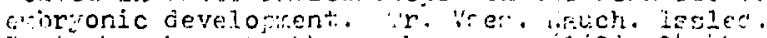

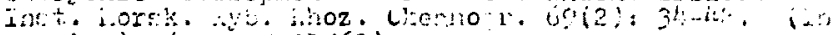

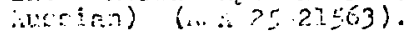


PAlhanova, I. A. A. A. Voronina, V. A. Pechikurenkov, $\therefore$. . Yarzhombel and I. B. biyashtorin. 1971. Ins:iruction on radiooiological investigatione of enibryonic eriod of fishes development. ir $r$. VEes. ivuch. Insled. Inst. : orel. $\mathrm{kyb}$. lhoz. Ckeanogr. (iio. i) (in guevian).

...tiliarova, I. A., A. A. Voronina, 1. B. lilyasitorir, V. I. Fechikurenkov and A. A. Yarzhombek. 1973. sifect of ionizine radiation on the biolotical coniilion oi iich. py.7-24. In: racioecoloes of iater ireanisue. III. 'the iffect of Ionizing riadiation on jater Creanisms. (G. F. Andrushaitis, ed.). iinn, Izd=tel'etvo zinatine. (binglish transl. Aictr-7592). (1)ín 30-24305; 31-11667).

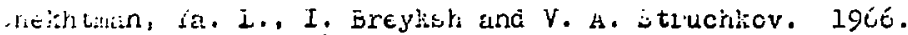
selative biological efficiency of fast nevitrons and Edítia reje on loach sperma and DNA of irradizted - perti. heulicioloeiya $6(4), 495-499$. (inelish

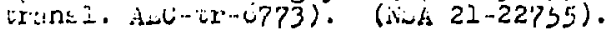

-riegter, $G$. $\dot{s}$ and I. A. Shekhanova. 1977. Influence oi Lonizing radiation upon some ractors of fish iamuni $\mathrm{jy}$. po. 93-94. In: Radioecclogy of Aninals. (…. Aleksadthin, cd.). "ivaka," inoscow. (In Gus aian).

froticinzen, I. I. 1950. The waye in which raciation demete appears in early ievelop:uent in fikh. joklas. níad. irauk SüR (Biol. sci.) lig(1). (english trans. is. $134-137)$.

Sirier, a. $\because$ and j. winn. 1967. the efítects of reciua on goldfish blood. Froc. Ltah scáa. Sciences, istim ard letere $44(2)$ : 600-605.

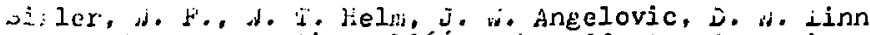
anci . a artin. 19ú6. the effects of uraniun aill Yastes on strean biota. itah ner. sxpt. ita...

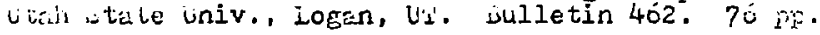

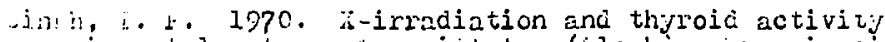
in a teicost, byttue vittatur (Elochj. Experientio

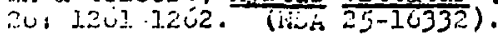


shauen, $\dot{D}$. $r$ 1964. The effects of tritium oxide on aquatic oreanisms. Hinal keport for Contract A's (30-1)-3039. June 1, 1962 through July 31, 19u't. Liniv. of Conn., U. S. H.EC report WNC-3039-1. $17 \mathrm{pg}$. (ikis 19-33). (Lebietes reticulatus).

welien, i., i. Lockner and G. Hevesy, 1964. hauio. sonsitivity of haemopolesis in rish. I. wtulier. at $100 \mathrm{C}$. Intern. J. Kzdiation diol. C(4): $317-32 \%$. (Lis 19-1.7549).

firnova, I. 3 . and 3 . 4 . Latis. 1970. Chane of radiosensitivity and of content of ir Eroupt in early enbryogenesis of the loach (wickurnus roisjli.;.

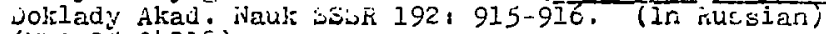
(ivi $25-24318$ ).

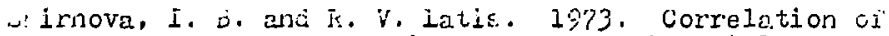
the chilount: of vrotoin and nonprotein thiolis anc the

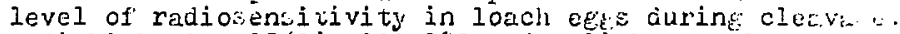

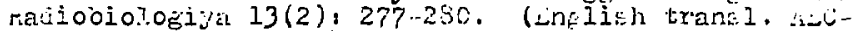
Tr-7444). (HA 2C-24502).

...irnova, I. 3. and t. ia. Graevshiy. 1977, Injurions intilucree of an irladiated ur on nonirraciated cpert. oi the lotich (i,isgurnue rosisilis i.). joklady itiad. daul: wisin (Biol. sci.) 237(5), 1219-1221. (ineliah irancl. $1.557-559)$.

mirnova, I. E., k. V. Latie ano L. V. rrolova. 1973. Gulozctivity of loach ege during cleavarc luner concitions o" colchicine -induced seprescion 01 nitosic. Raviobiologiya 13(3): 442-445. (En 7 ist

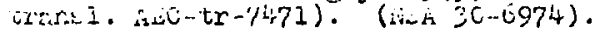

.Ailh, G. i.. 1932. sruptions of corial helanoplore and reneral cutaneous nelanosis in the coludish

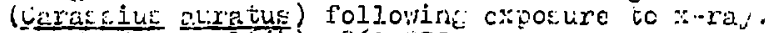
in. v. vencer 10(4): $863-670$.

s.if th, s. ... 1932, 1:elanophores induced by $x-r a y$ con. pered with those existine in wtierna at: 1

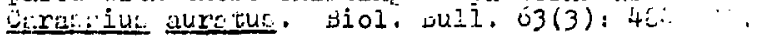

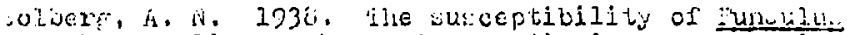
neteroclithe enturyoe to $x$-racisaion. u. Lxrtl. 5001. 7:(4): 4i4l-tín. 
zolver, $\therefore$. it. 193i. 'he surceptibility of the errm cells oi cryzias latipes lo $x$-radiation and recovery ajier treatment. J. Expt1. 3001. 7ن(4): 4l7-439.

urokin, V. F. 1grl. Introduction. Tr. Folyar. Wauch.I. $I$ Ieu. rroekt. Ine t. i.orek. nyt. hinor ckeanoe $r$. (29): 3-7. (unclich trans l. AcC-tr-74le). (rieb).

Suivastrva, $\ddot{5}$. ir. $19 t G$. Effect of ioni: in raviation on the ovarist of japanese tiedaka, (ryiala lalipes

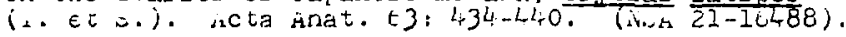

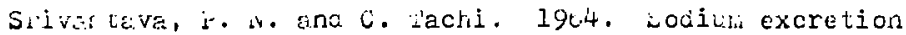
as 2 tactor caueint death in fich due to irradiation. itare 2n2(493c): 1234-1235. (ivin li-29330). (Gol:$\therefore i n)$.

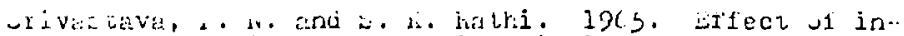
ief nal redioptosphorus: irradiation on ire ovary of intius oplore janilton. ixperientio. 21(3): 13313\% (Nis 19-21900).

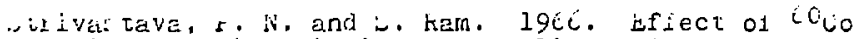
iniernal irracialion on the liver of ieteropreuste:

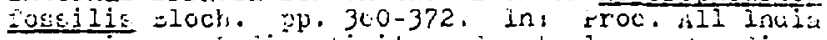
Juposiun on sacioactivity and fetrology ol saciio-

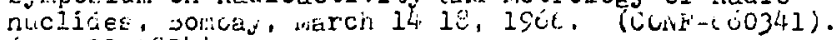
( $\therefore \therefore$ : $22-C E 74 ;$.

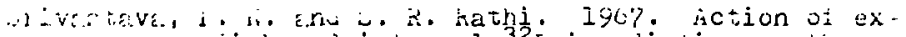
- enoue iish enc internel $32_{F}$ irradiation on tie cvary of the Incian catfich, Heterorncustes fosilis

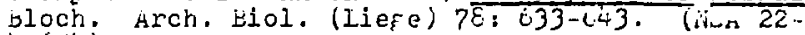
$i, 5,54)$.

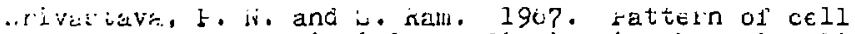
wite e ue to ionizin ratiation in the ejitultal linirs oj the intestine in heterckneustes tok:iiis 3.och. Experientia 23: 358-359. (ifos 2I-3090s).

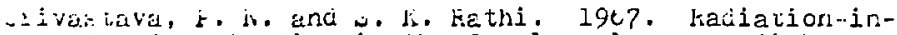
H.cer castration in the female teleostean fish. bieropneutes Yoseilis sloch. Experientie 23:22? 33 . (ix-it 21-22(98).

, i retava, I. and $\mathrm{S}$, iam. lof c uffect of internaliy injected raidoicotoper on the conne tive tierlie in thi indian caticli, acteropneustes foerilis bioc! .

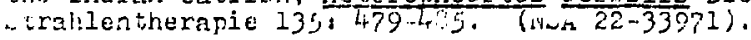


Srivastava, F. N. and S. Kam. 1969. Effect of t.oco internal irradiation on the liver of the Indian cat fish, Heteropneustes fossilis Bloch. Strahlentruapic 137: 499-507. (Nit 23-38758).

Srivertava, F. N. and S. li. kathi. 1970. iffect of radiation on the reproductive $s y$ ten of the Inciar catish, ieteronneustes fossilis Bloch. I. fnnual cycle in the developinent of ovarian eges. dicta inat. 75: $114-125$. (dij.s $25 \cdot 21858$ ).

Srivastava, P. N. and G. H. Mair. 1970. uffect of thrroid Etimulatine hormone and radiophosphorur irradiation on the blood components of Heteropneustes foseilis Hoch. Etrahlentherapie 139:565-570. (Nisi 25-590).

Srivastava, P. V., H. Etoh, Y. Hyodo and N. Egami. 1964. Thyroid activity and radiosensitivity relationship in goldfish, Carassius auratus L. Strahlentherapie 125 : 305-308. (NSA 19-155).

Ssmokhvalova, G. V. 1935. The influence of $x$-rays on the sex glands and the secondary sexual characters in Lebistes reticulatus. Tr. Dinamike Razvitiia 10. 213-229. (In Russian).

Ssmokhvalova, G. V. 1938. Effect of $x$-rays on fishes (Lebistes reticulatus, Ziphorphorus helleri and Carassius vulgaris). Biol. 2h. 7: 1023-1034.

Storozhuk, N. G, and I. A. Shekanova. 1977. Iipoperoxidation in liver and muscles of carp fingerlings after long-term exposure in an environment with higher content of radionuclides. pp. 89-91. Ins Radioecology of Animals. (R. H. Alekeakhin, ed.). "Nauka," Hioscow. (In Russian).

Stout, V. F. 1963. Effects of ionizing radiation on lipids of fish. U. S. Fish and Wildife Service, U. S. AEC report TID-18657, iii, 18 pp. (NSA 1737064 ).

Strand, J.A. 1975. Suppression of the primary immune response in rainbow trout. Salmo gairdneri. sublethally exposed to tritiated water during embryogenesis. Battelle Northwest, U. S. ERDA report BNisL-SA-5237 (Rev.). $152 \mathrm{pp}$. (Thesis). (ERA 1$1472,4)$. 
irat, j. A., A. I. Templeton and E. G. Tangen. 2973. $\therefore$ ccuinulation and retention of tritium (tritiated itier; in umbronic and larval fish, and radiation wifet. pp. 445-451. In: Radionuclides in eco$\therefore y$ ters. (D. $J$. Nelson, ed.). U. S. AEC report CCNE-710S01-11. (NSA 25-37714).

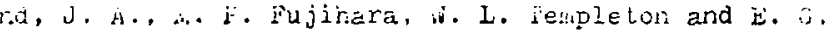
Tangen. 1973. Suppression of Chondrococcus columnaris immune response in rainbow trout sublethally exposed to tritiated water urine embryogenesis. pp. 543-549. In: Radioactive Contamination of the liarine crivironment. Intern. Atonic Energy Agency. Vienna, Austria, publication STI/FUE/313. (NSA $28-8462)$.

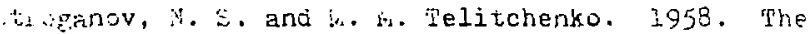
chronic effect of $\varepsilon$ mall doses of $0-238$ on bleak conads. (Kead in November, 1957). Byul1. I. osk. iosticin. Ispyt. Frirody (Biol.) 63(4): 154. (Ř... an. (idol,) 1959:44599; BA 45(13): 54124).

s...: ierk, ij, E., S. ir. Adans, B. G. Blaylock, C, C. Coulant ar. C. A. Guthrie. 1978. Growth of monosex hyoric alapia in the laboratory and sewage oxidation ponas. Uak kiage Nationai Lab., U. S. DCE report CCNF7iuls\%-1. $18 \mathrm{pp}$. (ERA 3-57604). (Includes gamna (adiation).

Suyeirio, $Y$. 1954. Effect of radioactive substances upon fishes. Kagaku 24(12): 619-622.

Janaia. P. 1942. Influence of the ray of helioiamp upon the hatchability of Oncorhynchus keta (Walbcum). 3001. kag. (Tokyo) 54(8):313-314. TIn Japanese).

$\ldots \pi \ldots a . \dot{k}, 1942$. Effect of $x$-ray irradiation on the natching of the eges of Oncorhymchus keta Walbaum. 3uil. Jap. Soc. Sci. Fish. ll(I): 39-40. (Iil Japanesei.

$\because 0, i$. 1972. Effects of irradiation ${ }^{60} \mathrm{Co}$ gramma-ra: un the maturation of rainbow trout. 5ull. vap. Soc. sici. íish. 38(8): 793-79?. (In Japanese witn inglich abstract) (N\&A 29-27079). 
Telitchenko, $\dot{r}$. h. 1962. The continuing effect of elevated concentration of uranium on the fertility and survival of guppies (Lebistes reticulatus). Byull. Wosk. Obshch. Ispyt. Frirody (Biol.). 67(3): $156-157$. (BA 42-358).

"Llitchenko, K. K. and Ye. K. Levitova. 1959. Histologic study of the gonads of bleaks (Alburnus L.) exposed to small chronic doses of U238. Vestnik i.oskov Univ., Ser. Biol., Fochvovedenie, Geol. i. Geograf. (1): 45-48. (English transl. AEC-tr-4004). (NSA $14-12410)$.

ielitchenko, ii. $\mathrm{i}$. and 'i'. I. Chistyakova. 1965. Changes in concentration of nucleic acids in the Eonads of Leucaspius delineatus after exposure to uraniun. Doklady Akad. Nauk SSsk l6l(4): 962-963. (EnElish transl. pp. 37-38). (NSA 19-43769).

ielysheva, I. G, and Yu. A. Shuljakovskiy. 1973. Radioresistance of eggs of some industrial fish. pp. $7 \varepsilon$ 88. In. Radioecology of iater Oreanisms. III. 'The iffect of Ionizine Radiation on water creanir r!! . (G. F. Andrushaitis, ed.). Rifa, Izdatel'stvo Einatne. (EnElish transl. AEC-tr-7592). (NA 3024375; 31-11671).

i'empleton, W. L. 1966. Kesistance of fish eegs to acute and chronic irradiation. pp. 847. Bt.0. In: Disposal of Radioactive wastes into Seas, cceans and surface waters. Intern. Atomic Energy Afency, Vienna, Austria, publication STI/FUB/126.

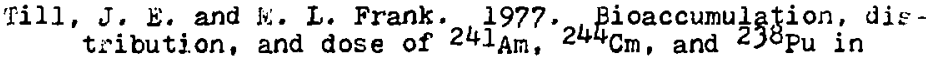
developing fish embryos. Proc. 4th Intern. Coner. of the Intern. Radiation Frotection Association 2: 645-648. (ERA 3-43714).

i'ill, J. E., S. V. isaye and J. R. Trabalka. 1976. The toxicity of uranium and plutonium to the developing. embryos of fish. Cak Ridge National Lab., U. $\dot{A}$. Liva report CKNL-5160. xiv, $189 \mathrm{pp}$. (Dissertation of J. E. Till, ueorgia Institute of Technology). (Ekh26650). (Cuprinus carpio, Pimephales promelas). 
:imofeyeva, N. A. and L. K. AI'shits. 1970. Influence of chronic irradiation upon development of pike eggs (Esox lucius). pp. 8- . In: Action of Ionizing hadiations upon fydrobionts and Land Plants. Trudy Instituta kkologii Rasteniy i zhivotnysh, sverdlovsk 74. (In Russian).

"'rabalka, J. R. and C. F. Allen. 1977. Hepects of fitness of a mosquitofish Gambusia affinis population exposed to chronic low-level environmental radiation. Padiation Res. 70(1): 198-211.

Tsufawa, $Y$. and $r$. Yamamoto. 1960. On Lebistes reticulatus perception of $\mathrm{x}$-radiation. Fart I. Kanazawa ifed. jci. ¿er. 57. pp. ? (In Japanese).

'Uugawa, $\because$ and K. Yamamoto. 1962. On Lebistes reticulatus perception of $x$-radiation. Fart II. lanazawa lied. jci. ier. 66. pp.': (In Japanese).

": jpin. A. B. 1964. Conditioned reflex during $60 \mathrm{Co}$ gamna irradiation of fish and rabbits. pp. 46-49. In: Pathoteneris, Sxperimental Prophylaxis and Therapy of Radiation Injuries. ( $A$. V. Lebedinskiy, ed.). . oscow, ..edEiz. (In Russian) (Nis 20-38655).

rypin, A. S. and Yu. A. Sholodov. 1964. Development of a conditioned reflex to ionizing radiation in fish and rabbits. Radiobiologiya 4(3): 402-40E. (English transi. AEC-tr-6406). (NSA 18-33366). (Carp).

"Eytsugina, V. G. 1971. Effect of incorporated radionuclides on the chromosomal apparatus of marine fish. Ir. Polyar. Nauch. -Issled. Proekt. Inst. Horsk. Ryb. Khor. Okeanogr. (29), 128-134. (English trans 1. AECtr-7/t8). (NSA 27-28006).

I'sytsueina, V. G. 1973. Wethods of karyological and radiation cytogenic investigations of marine fishes. pp. 7- . In: Artificial and Natural Radionuclides in liarine Iife. (V. G. Tsytsugina, N. S. Risik and G. E. Iazorenko, eds.). "Naukova Dumka," Kiev. (English trans1. TT75-50010; pp. 1-2).

Gytsugina, V. G., N. S. Kisik and G. E. Lazorenko. 1973. Chp. II. Karyology of marine fish and the effect of radionuclides on their chromosome apparatus. pp. 2658. In: Artificial and Natural Radionuclides in i.arine life. (V. G. Tsytsugina, N. S. Risik and G. i. Lazorenko, eds.). "Naukova Dumka," lilev. (English trans1. TT75-50010; pp. 16-39). 
ilrikson, G. U. 1969. Use and effects of cobalt-60 for sterilization of bluegills (Lepomis macrochirus). Thesis. Univ, of Michigan, Ann Arbor. $148 \mathrm{pp}$. (Diss. Abstr. 1969:2473B).

Ulrikson, G.U. 1973. Radiation effects on serum proteins, hematocrits, electrophoretic patterns and protein components in the bluegill (Iepomis macrochirus). pp. 1100-1105. In: Radionuclides in Ecosystems. (D. J. Nelson, ed.). U. S. AEC report CCNF-710501-F2. (NiA 26-30142).

Umanskiy, S. R. 1968. Influence of irradiation on the composition of messenger RNA during early loach embryogenesis. Radiobiologiya $8(3): 347-353$. (english trans1. AEC-tr-6916). (NSA 22-5138E).

Vakhrameyeva, N. V. and A. A. Neyfakh. 1959. Comparison in the changes of radio- and thermo-sensitivity during cleavage in the loach, gisgurnus fossilis. Doklady Akad. Nauk Sisin (Biol. Eci.) 126(2): 429433. (English transl. pp. 779-782).

Vasil'yev, O. F. and A. I, Sherstnev. 1965. Effect of strontium-90 on the formed elements of fish blood. pp. 56-57. In: Froblems of liydrobiology. hoscow. Fubl. House Acad. '́ci. USiR. (In Russian).

Vaseileva-Dryanovska, 0 . and $R$. Belcheva. 1965. räadiation gynogenesis in Salino irideus Cibb. Colft. Strid. Acad. Bulg. Sci. 18, 359-362. (NSA 21-22686).

Velikhanov, E. E. 1976. Experimental study of mutual influence of oil and ionizing radiation upon eggs and larvae of stureeon. Isv. Akad. Nauk Azerbayozhanskoy SER, Ser. Biol. 4: 99- . (In kussian).

Venkataraman, $i$. V. 1974. Effect of gamma radiarion on two developmental stages of zebra fish eggs. Curr. Sci. (India) 43(11): 355-356. (N)A 30-12996).

Vinogradova, I. D. and Ya. T. Shekhtman. 1968. Effects of certain protectors on the survival of embryoc and the viscous properties of DNA in the case of irradiation of loach sperm. Radiobiologiya $8(\varepsilon) .811-815$. (English transl. AEC-tr-7013). (NSA 23-18084).

Vivien, J. H. 1950. hiasculinization of xiphophores females by $x$-irradiation of the gonad. Compt. Rend. 231(21): 1166-1168. (In French) (NSA 5-2339). 
Vivien, J. 2953. Effects of radiophosphorus $\mathrm{P}^{32}$ on the Eonads of viviparous cyprinodontes. Compt. Rend. 236: 535-538. (In French) (NSA 7-1877).

vivien, J. 1953. Total sterilization of the gonads after treatment with radioactive phosphorus, in the cyprinodontis: Lebistes and Xiphophores. Compt. Rend. 236: 2172-2174. (In French) (NSA 7-4713).

Voronina, E. A. 1972, Dynamics of weight and linear growth of Tilapia mossambica Feters, Erown in closed aquaria with different content of $90_{\mathrm{ir}}-90_{Y}$. Tr. Vees. Nauch.-Issled. Inst. ilorsk. Ryb. Khoz. Ckeanogr. (85): 31-. (In Russian).

Voronina, E. A., S. P. Peshkov and I. A. Shekanova. 1977. Biological indicators of chronically irradiated populations of Carassius auratus gibelio. pp. 71-73. In: Kadioecology of Animals. TR. Th. Aleksakhin. ed.). "Nauka," Moscow. (In Russian).

Wadley, 6. W. 1971. Effect of $x$-irradiation under various temperature conditions and embryonic developmental stages on the growth and mortality of chinook salmon. Thesis, Univ. of Washington, Seattle. (Uniy. Kicrofilms Order No. 71-28,488). 125 pp. (NSA 26-4838; 26-23112).

Wadley, G. W. and A. D. Welander. 1971. X-ray and temperature: Combined effects on mortality and growth of salmon embryos. Trans. Am. Fish. Soc. 100(2): 267-275. (NSA 25-44925).

Walden, S. J. 1973. Effects of tritiated water on the embryonic development of the three-spine stickleback, Gasteros teus gculeatus. Iinnaeus. pp. 1087-1090. In Radionuclides in Ecosystems. (D. J. Nelson, ed.). U. S. AEC report CONF-720501-F2. (NSA 26-2415).

Hard, E., S. A. Beach and E. D. Dyson. 1971. The effect of acute $x$-irradiation on the development of the plaice Pleuronectes platessa L. J. Fish Biol. 3(2), $251-259$.

Watson, D. G., I. A. George and P. I. Hackett. 1959. Effects of chronic feeding of phosphorus -32 on rainbow trout. pp. 73-77. In, Hanford Biology Research Annual Report for 1958. Hanford Atomic Products Operation, U. S. AEC report HW-59500. 
Watson, I. J., I. I. Shechmeister and I. I. Jackson. 1963. The effect of $x$-irradiation on goldfish. II. The effect of total-body $x$-irradiation on the hematology of Carassius uratus. Phys101. 2001. 36(4). 370-382. (BA 45-22865).

Welander, A. D. 1945. Studies of the effects of roentgen rays on the growth and development of the embryos and larvae of the chinook salmon (Oncorhynchus tschawytscha). Univ. of Washington. U. S. AEC report UWFI-2. $131 \mathrm{pp}$.

Helander, A. D. 1954. Some effects of x-irradiation of different embryonic stages of the trout (Salmo gairdnerii). Growth 18(4): 227-255. (Also: Univ. of Washington, U, S. AEC report UWFL-38). (NSA 9-5844).

Welander, A. D. 1971. Effects of irradiation and temperature on young salmonids. Final Report. Univ. of Washington, Seattle. U. S. AEC report RLO-2225-T8-5. $16 \mathrm{pp}$. (NSA 26-4839).

Welander, A. D., G. W. Wadley and D. K. Dysart. 1971. Growth and fecundity of rainbow trout (Salmo gairdneri) exposed to single sublethal doses of $x$-rays during the eyed embryo stage. J. Fish. Res. Bd. Car. 28(8): 1181-1184. (NSA 26-9634).

Welander, A. D., I. R. Donaldson, R. F. Foster, K. Bonham and $A$. H. Seymour. 1948. The effects of roentgen rays on the embryos and larvae of the chinook salmon. Growth 12(3): 203-242. (Also: Univ. of Washington, U. S. AEC report UWFL-8; MDDC-1689). (NSA 2-27).

Welander, A. D., I. R. Donaldson, R. F. Foster, K. Bonham, A. H. Seymour, and F. G. Lowman. 1949. The effects of roentgen rays on adult rainbow trcut. Univ. of Washington, U. S. AEC report UWFI-17, AECU-188. 20 pp. (NSA 2-1888).

White, J. C., Jr. 1964. Fractionated doses of x-radiation, A preliminary study of effects of teleost embryos. Intern. J. Radiation Biol. 8(1), 85-91. (NSA 195662 ).

White, J. C., Jr. and J. W. Angelovic. 1966. Tolerances of several marine species to Co-60 irradiation.

Chesapeake Sci. 7(1), 36-39. (6 species of marine teleosts, 2 species of marine invertebrates--mud snail (Nassarius obsolecus), sea urchin (Arbacia punctulata)). 
White, J. C., Jr, and J, W. Angelovic. 1973. Interactions cI chronic gemma radiation, salinity, and temperature on the morphology of postlarval pinfish, Iagodon rhomboides. Pp. 199-217. In: Proc. of Jorkshop on EgE, Larval and Juveni le Stages of Fish in Atlantic Coast Estuaries. NOAA Tech. Fubl. No. 1.

Wone, A.-C, and C.-1. Wang. 1960. The effect of embryonic development of goldfish from exposing the parent fish to $x$-raye. Acta Z001. Sinica $12(1), 127-130$. (NSA 19-169).

Noodhead, D. S. 1977. The effects of cironic irradiation on the breeding performance of the Euppy, Poecilia reticulata (Osteichthyes: Teleostei). Intern. J. kadiat. Biol. $32(1)$ : 1-22.

Yoshimura, N. and H. Etoh. 1969. Notes on the effects of beta-rays from $90 \mathrm{Sr}-90_{Y}$ on spermatogenesis in the teleost, Cryzias latipes; Annot. Zool. Japan $1+2(2): 75 \cdot 79$. (NSA 23-50877).

Zizupina, V. G. 1970. Action of incorporated radionuclides on chromosome apparatus of marine fishes. pp. 129-134. In: jarine Radioecology. (G.G. Folikarpov, ed.). Kiev, Fublishine House acad. Sci. likr. :R. (inglish transl. AliC-tr-7299). 


\section{Amphibians}

Afrikanova, I. A. 1963. An experimental study of early structural changes of an irradiated, interauricular septum of a frog. (Live and histochemical observations). Radiobiologiya $3(2)$ : 300-310. (U. $\therefore$. AEC transi. AEC-tr-5435). (NAA 17-30368).

Algard, F. T., C. B. Friedmann and H. k. kicCurdy. 1974. Responses of adult newts (Anphibia: Urodele) to $x$ rays. Can. J. 2001. 52(6): 665-669. (NSA 30-24338).

Allen, B. M. 1956. Cell destruction induced by heavy irradiation of recently metamorphosed Bufo (abstr.). Anat. Record 124(2): 38 .

Allen, B. H. 1956. Interpretation of some experiments upon the effects of ionizing irradiation on the tissues of amphibians. Ann. 2001. 2(9), 119-126.

Allen. B. M. 1957. The effects of heavy gamma irradiation upon pituitary glands transplanted into hypophysectomized tadpoles of Bufo boreas. J. ExptI. 2001. 136(1): 185-198. (N5A 12-11243).

Allen, B. $\%$. 1958. Effects of $x$-irradiation upon the limb-buds of Bufo boreas (abstr.). Anat. Record 130 (2): 391-392.

Allen, B. M. and O. A. Schjeide. 1951. The influence of anoxia upon destruction and mitoses of the hematopoietic cells of $x$-irradiated tadpoles. Univ. of Calif. at Los Angeles, U. S. AEC report UCLA-149. 13 pp. (NSA 5-4972).

Allen, 2. ... and 3. 2. Bachman. 1956. The eff'ects of critical dosages of gamma irradiation upon the capacity of the pituitary gland to secrete thyrotrophic hormone. J. kxptl. 2001. $132(1)$ : 111-132. (Also: Univ. of Calif. at Los Angeles, U. S. Aic report UCLA-324). (NSA 9-2550). ('i'oad).

Allen, B. $\mathrm{A}$, and K. H. Devick. 2957. Differences in susceptibility to whole-body gamma irradiation in the layers of the retina of Bufo. Biol. Bull. 112 (2), 137-143. (NSA 10-3969). 
$\therefore$ Ien, B. i. and I, i.j. Ewell. 1959. Resistance to $x$-irradiation by embr/onic cells of the limb-buds of tadpoles. J. Expt1. 2001. 142: 309-335. (NSA $15-14139)$.

Allen, B. H., C. A. Schjeide and R. Piccirillo. 1951. the infiunce of anoxia upon destruction and mitosis of the netiatopietic cells of $x$-irradiated tadpoles. Univ. of Calif. at Los Angeles, U. S. AEC report UCIA-149. 13 pp. (NES 5-4972).

Allen, B. b., O. A. Schjeide and L. B. Hockwald. 1951. The influence of temperature upon the destruction of $x$-rayed hematopoietic cells of tadpoles. J. Cell. Comp. Physiol. 38(1): 69-82. (Also: Univ. of Calif. at Los AnEeles, U. S. AEC report UCLA-93). (NSA $5-286)$.

Allen, B. M., O. A. schjeide and R. Piccirillo. 1954. Influence of anoxia upon hematopoietic cells of tacipoles exposed to $x$-irradiation and colchicine. J. Cej1. Comp. Physiol. 4h(2), 318-322.

Allen, B. in., O. A. Schjeide, W. J. hillard and $R$. iccirillo. 1953. Relation of x-irradiation dosage and elapsed time to the destruction of hematopoietic cells of tadpoles. J. Exptl. 2001. 122(3), 409-422. (Also: Univ. of Calif. at los Angeles, U. \&. AEC report $\operatorname{VCLA} \cdot 232$ ). (NSA 7-475).

Allen, B. M., O. A. Schjeide, $\mathrm{i}$. T. Ficcirillo and G. kowitz. 1953. The capacity of the anterior pituitary gland to function after heavy irradiation. J. Exptl. 2001. 124(1)! 131-146. (Also: Univ. of Calif. at Los Angeles, U.S. AaC report UCIA-254). (NEA 7-3688). (Toad).

Amoroso, C. and w. Iorenz. 1959. The question "recovery speed or resistance increase" of the $x$-irradiated skin of frogs (Rana esculenta) in small fractionation. Strahlentherapie 108: 84-92. (In German) (NSA 13-8589).

Ancel, F, and F. Vintemberger, 1925. Influence de la rapidite d'evolution de l'oeuf irradie de Rana sur la duree de sa survie. Compt. Rend. Soc. Biol. 93: $281-283$. 
Ancel, F. and F, Vintemberger. 1925. The effect of $x$-rays on embryonic development. Do the rays have an accelerating effect? Arch. Biol. 35, 1-43. (In French) (Includes firtilized frog eges).

Ancel, F. and P. Vintemberger, 1927. Influence de la temperature sur la radiosensibilite d'oeufs d'Ciseaux et de Batraciens. Compt. Rend. Soc. Biol. $9 i:$ 796-799.

Anno, $Y$. and $H$. Cga. 1959. Early reactions on the blood rescels of the frog tongue after irradiation with ise ta rays. Strahlentherapie 109: 144-149. (In jerman) (NSA 13-16731).

Antonijevic, it. and D. Lebez. 1965. Studies on the nitrogen metabolism in frog liver after whole-body irradiation. III. Effect of histamine and cysteine on nitrogen excretion from isolated frog liver after whole-body irradiation. Strahlentherapie 127: 303307. (NSA 19-33933).

Antonijevic, li. and $\mathrm{D}$. Lebez. 1966. studies on the nitrogen metabolism in frog liver after whole-body irradiation. IV. Influence of splenectomy, spleen extract and serum of irradiated frogs on the nitrogen excretion by perfused frog liver. Strahlentherapie 130: 280-284. (NSA 20-18207; 20-35307).

Arvy, I., J. A. Boiffard and J:. Gabe. 1947. Les nodifications de 1 'hemogramme determinees chez Rana temporaria I. par l'irradiation de l'hypophyse aux rayons $X$. Compt. Rend. Soc. Biol. 14l: 455-457.

Ashizawa, A. 1959. Effect of irradiation at lower temperature on the regeneration of the amphibian tail. Nippon IEaku Hoshasen Gakkai Zasshi 19: 1416-1434, (NíA 15-22100).

Ashton, $\mathrm{V}$. 1956. The effects of whole-body irradiation on the melanophores of the common frog (Rana temporaria). pp. 419-426. In: Progress in Radiobiology. (J.S. Witchell, B. E. Holmes and C. L. Smith, eds.). Charles C Thomas, Springfield, II.

Bachofer, C. S. and S. E. Wittry. 1962. Comparison of electroretinal response to $x$-rays and to light. Radiation Res. 17(1): 1-10. (NSA 16-21976) (FroE). 
Sachofer, C, $̈$. and 3 . E. Uittry. 1962. Comparison of $\because$ i, inuius energies required to elicit the ERG in cepone $i 0 x-$ reys and to lifht. J. General Physiol. $\therefore$ (2): 177-187. (NSA 17-13900). (Rana pipiens).

Jaldwin, . . . 1915. The action of ultraviolet raye 1.jon l!i. iset efe. nuat. Record 9(5): 365-j81.

3aliwin. N. it. 1919. The artificial production of monsters conforming to a definite tyre by means of x.rays. Anat. Hecord 17(3): 3.35-164. (Tadpole).

jaliwin, 4 . 1. 1920. The artificial production of monsters demonstrating localized defects as the result of injury from $x$-rays. Am. J. Physiol. $52(2): 29 t$ 303. ('iadpole).

saldwin. W. K. 1921. The artificial production of syringomyelocoele in the tadpole by means of $\mathrm{x}$-rays. hinat. hecord 22: 305 .

sergeder. H. J. 1958. Potassium loss of cold-blooded Jikeler after $x$-irradiation. Naturwiseenscheften $45(3), 61$. (In German) (Frog).

Berpeder, H. D. and 0 . Hockwin. 1960. Alteration of the oxyfen consumption of isolated frog muscle after $x-$ irradiation. Naturwissenschaften $47(7): 161$. (In Serman).

Bergeder, $H, D$, and $D$, Boening. 1965. Immediate effects of $x$-rays on invertebrate animals and frogs. Biophysik 2: 239-246. (In German) (NEA 19-42271).

Bertstrom, R. ir. 1961. The effect of 5.3-hev polonium210 alpha particles on the electrical activity of $x-$ and 2 -ficers of the frog sciatic nerve. Ann. fied. Exptl. Biol. Fenniae (Helsinki) 39(3), 211-215. (NSA 17-21483).

Derestrom, R. i.., R. Blafield and A. Salmi. 1962. Effect of roentgen irradiation on the elasticity of frog skin. Acta Radiol. 58(2): 141-147. (NSA 16-21921).

3lair, A. F. 1960. Ladiation-induced genetic damage in the biexican toad (Bufo valliceps). Texas J. Sci. $12(3): 216-227$. 
Blair, w. F. 1961. Effect of radiations on natural populations of vertebrates. pp. 1377-1381. In: Recent Advances in Botany, Univ. of Toronto Fress, Toronto, Canada. (Includes Bufo valliceps).

Blinov, V.A. 1950. Action of $x$-rays on the embryonic development of amphibia. Doklady Akad. Nauk SSif: 74: 401-404. (iISA 5-517).

Blinov, V. A. 1956. The varying seneitivity of amphibian embryos to the effect of $x$-rays at various siages in their development. pp. 159-184. In: Froblems of Radiobiology. (k. N. Fobedinskiy and P. N. Kisleva, eds.). Leningrad, i.edgiz. (In Russian).

Blum, j., $\vec{F}$. E. G. Eutler and $\because$. E. Uchmidt. 1958 . kegeneration of limb abnormalities after UV irradiation. J. Cell. Comp. Fhysiol. 52(8): 177-186. (Lrodele).

Slun, F. F., L. G. sutler, J.J. Chane, K. C. l:awe and ‥ E. ichmidt. 1957. Studics on regression and regeneration in the urodele forelimb after localized ultraviolet radiation. J. Cell. and Comp. Fhysiol. 49(1): $153-169$.

Bogonoletz, V. I. 1961. Effect of $x$-ray irradiation on the membrane potential and concentration of sodium and potassium in frog muscle fibers. Fiziol. zhur., Akad. Nauk Uicr. RSR 7, 214-219. (English transl. JPRS-9971). (NSA 15-29004).

Bohn, C. 1903. Influence des rayons du radium sur les animaux en voie de croissance. Compt. Rend. 136(17): 1012-1013. (Bufo vulgaris).

Boiffard. J. A., M. Gabe and L. Arvy. 1947. Effets des rayons $X$ sur la hypophyse de Rana temporaria $I$. Compt. Rend. Soc. Biol. 141, 340-341.

Bordeen, C. R. 1907. Abnormal development of toad ova fertilized by spermatozoa exposed to the roentgen rays. J. Expt1. 2001. 4(1): 1-44; 5 plates.

Bordeen, C. R. 1909. Variations in susceptibility of amphibian ova to $x$-rays at different stages of development. Anat. Record 3(4): 163-165. 
3rores. $2 . \%$ 29ii. Further studies on the variation s suscet:ibility of amphibian ove to the $x$-rays at

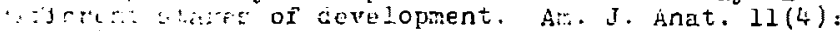

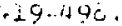

Both, $A . \therefore$ J the The influence of ionitine radiations

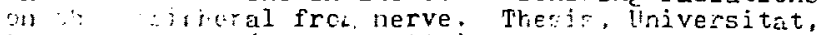

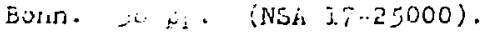

Brifre, $\bar{i} ., \hat{\mathrm{E}}$. L. Green and $\mathrm{i}, \mathrm{J}$. Kinf. 1951. An investipation of the capacity for cleavare and differentiation in Rana pipiens eggs lacking "functional" chromosomes. J. Expt.. 2001. 116(3): 455-499. $(\mathrm{X}$-irradiated $\mathrm{s}$ perm $)$.

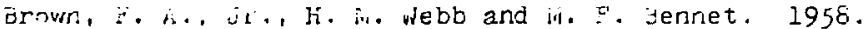
Comparicone of some rluctuations in cocmic railation end in organismic activity during 1954,1955 and 1956. Am. J. Fhyeiol. 195(1): 237-243. (Includes ce purnax, priturus, Pucus, quahog).

Eruns 1., $\vartheta . \forall, 1944$, Untersuchungen des ïinflusses von roentgenetrahlen auf die Entwicklung bei Amphitien. d. Koux Entw. d. Orean. 142: 706-739.

brunst, $v . v$. 1950. Influence of $x \cdot$. ays on limb regeneration in urodele amphibians. duart. Rev. Biol. 25: 1-29. (NSA 4-3283).

Erunzt, V. V. 1954. The effect of local x-ray irradiation upon the development of the anterior part of the head of the axoloti. J. horphol. 95(2), 373-391

Brunst, $V . V$. 1955. The influence of roentgen irradiation on the development of the eye of axolotl. Am. ;. Rontfenol. Radium Therapy Nucl. Hed. 73(2): 281$\therefore 3$.

Brunst, $v . V$. 1955. The reaction of the skin epithelium of the tails of Rana catesbiana tadpoles to local $x$-irradiation. Radiation Res. $2(6): 556-567$. (NSA $9-6842)$.

Erunst, V. V. 1956. Investigation of the lethal effect of $x$-irradiation on the young axolotl (Siredon mexicanum). Radiation Res. 5(3): 267-280. (Nis 10-11650). 
Brunst, v. v. 1957. Histopathology of roentgen death of young axolotl (Siredon mexicanum). Am. J. Roentgenol. Radium Therapy Nucl. Med. $78(3)$ : 518-545.

Brunst, v. v. 1958. Effect of irradiation on some portions of head of young axolotl. Froc. Soc. Expt1. B101. lied. 99(3): 571-574.

Brunst, V. V. 1958. The effect of different doses of roentgen rays on adult axolotl (Siredon mexicanum). Am: J. Roentgenol. Radium Therapy Nucl. Wed. 80(1): 126-142. (NGA 12-10301).

Brunst, V. V. 1958. The effect of total-body $x$-irradiation on the adult axolotl (Siredon mexicanum). Radiation Res. 8(1): 32-45.

Brunst, v. V. 1958. The roentgen sensitivity of various portione of the eye of young axolotl (Siredon mexicanum). Am. J. Roentgenol. Radium Therapy Nucl. Ked. $80(6)$ : 1014-1030. (NSA 13-1900).

Brunst, V. V. 1959. Further investigation of the effects of roentgen irradiation upon the development of the head of the young axolotl. Am. J. Roentgenol. Radium Therapy Nucl. Nied, 82, 708-719. (NSA 1320806).

Brunst, v. v. 1959. Roentgen regression and roentgen stimulation in axolotl (Siredon mexicanum). Acta Unto Intern. Contra Cancrum 15: 568-576. (NSA 147222).

Bmunst, v. V. 1960. Raaction of $11 \mathrm{mb}$ regenerates of adult axolotl (Siredon mexicanum) to $x$-irradiation. Radiation Res. 12(6): 642-656.

Brunst, v. v. 1963. Successive changes in the cornea of young axolotl (Siredon mexicrnum) after $x$-irradiation. Radiation Res. 20(3): 325-340. (NSA 18-1418).

Brunst. v. v, 1963. The successive changes in the skin epithelium of the young axolotl (siredon mexicanum) after roentgen irradiation. Am. J. Roentgenol. Radium Therapy Nucl. lied. 89(1); 624-647. (NSA 1714000). 
Brunst, v. V. 1965. Effects of lonizing radiation on the development of amphibians. Quart. Rev. Biol. $40(1): 1-67$. (NSA 20-3773).

Brunst, v. v. 1965. Histopathology of the development of the axial skeleton and spinal cord in the irradiated tail of the young axoloti (Siredon mexicanum ). An. J. Roentgenol. Radium Therapy Nuc1. Píed. 95: 992-1012. (NSA 20-5312).

Brunst, V. V. 1965. New observations concerning roentgen sensitivity of pigment cells in young axolotls (iiredon mexicanum). Am. J. Roentgenol. Radium Therapy Nucl. Nied. 93(1): 222-237. (NSA 19-8812).

Brunst. V. V. 1965. The response of the cornea of the adult axoloti (Siredon mexicanum) to $x$-radiation. Expt1. Eye Res. 4: 127-134. (NSA 20-82).

erunst, V. V. 1965. The response of the olfactory epithelium of the adult axolotl (Siredon mexicanum) to roentgen irradiation. Am. J. Roentgenol. Radium therapy Nucl, Hed. 94(4), 964-983. (NSA 19-35965).

Brunst, V. V. 1969. Destructive effects of strictly local irradiation of the eye of the adult axolotl (Siredon mexicanum). Radiation Res. 39(1):26-35. (NSA 23-35890).

Brunst, V. V. 1969. The effects of partial irradiation on tail regeneration in adult siredon mexicanum. Am. J. Roentgenol. Radium. Therapy Nucl. Hied. I05. 196-206. (NSA 23-12218).

Brunst, V. V. and F. H. J. Figge. 1951. The development of eccondary tails in young axolotls after local $x-$ ray irradiation. J. Bjorphol. 89(1): 11l-133. (NSA $5-6573)$.

Brunst, V. V., E. A. Sheremetieva-Brunst and F, H. J. Figge. 1953. A comparis on of the reactions of the irradiated parts of the bodies of two day old mice and urodele amphibians to roentgen treatsent. Am. J. Roentgenol. Radium Therapy Nucl. Hed. $70(2)$ : 283-293. (NSA 7-6345).

Brunst, V. V., E. A. Sheremetieva-Brunst and F, H, J. Figfe. 1953. The effect of local $x$-ray irradiation upun the teeth and surroundine tissues in young axolotls. J. Dental Research 31: 609-619. (NSA 7-1044). 
Bucker, H. and $W$. Hanke. 1957. The reaction of the caplilaries and of the web tissue of the foot of the frog (Rena temporaria L.) to UV radiation. 2. Naturforsch. 12b(10), 629-641.

Bucker, H. and W. Hanke, 1958. Comparison of the effect of ultraviolet and $x$-rays on the capillaries of the frog's web. Nature $182(4646): 1375-1376$.

Buckheim, C. E. 1962. Lethal effects in tadpoles $02^{\circ}$ Xenomus laevis (Daudin) after irradiation with high energy electrons. Nature 196(4857): 902-903. (NSA 17-7861).

Butler, E. G. 1933. The effects of $x$-radiation on the regeneration of the forelimb of Amblystoma larvae. J. Expt1. Z001. 65(3), 271-315.

Butler, E. G. 1935. Studies on limb regeneration in $x$-rayed Amblystoma larvae. Anat. Record 62(3): 295-307.

Butler, E. G. and J. P, O'Brien. 1943. Effect of localized $x$-radiation on the urodele limb. Anat. Record $84(4), 407-413$.

Butler, E. G., H. F. Blum and S. E. Schmidt, 1957. The localized character of ultraviolet effects on the urodele forelimb. J. Cell. Comp. Physiol. 50(3): 381-388.

Eychkovskaya, I. B. 1959, The problem of the retention of radiation injury in epithelial cells of corneas of frogs irradiated during hibernation. Tsitologiya I(4): 387- . (English transl. JPRS-2287). (NSA 14-23939).

Bychkovskaya, I. B, 1960. Some data on the mechaniem of "conservation" of the radiation effect in the corneal epithelium of the frog under hibernation conditions. Hed. Radiol. 5(3), 73. (English transl. JPRS-5124). (NSA 14-13619; 14-25300).

Bychkovekaya, I. B. and R. B. Strelkov. 1967. Study of the protective efiect of beta-mercaptoethylamine in expertmente on froge (concerning the problem of the method of estimating the effectiveness of radioprotective agents). Radioblologiya 7(3): 452-454. (Englion transi. AEC-tr-6888). (NSA 22-10816). 
Cali, A, and $V$. Verga. 1960. Effects of $x$-rays on the permeability of capillaries (Study of the mesentery of kana esculentail. Strahlentherapie 112: 604-607. (In German) (WSA 14-22787).

Carlson, B. if. 1970. The effect of $\mathrm{x}$-irradiation and beryli'ur! nitrate upon implant-induced supernumerary linb formation in the newt. Oncology 24: 31-47. (NSA 24-27686).

Carosi, G., G. Gerna, G. Santagati and E. Cerra. 1967. Certain aspects of the morphogenesis of the heteroploid cells from abnormal mitosis caused by $x$-rays. Arch. Sci. lied. 124,592-599. (In Italian) (NSA 23-31885). (Newt).

Chang, C. and L. T'suang. 1965. Enhancement of functional activity of pars intermedia following $60^{\circ} \mathrm{Co}$ irradiation in the toad. Shih Yen Sheng Wu Hsueh Pao 10: 33-38. (In chinese) (NSA 20.5394).

Chasovrikov, N. 1928. The effect of $x$-rays on the fine stricture of frog liver cells. Sibirsk. Arkhiv T'eor. Klîn. lied. 3(1): 214-221.

Chopra, D. F. 1972. Some effects of $\mathrm{x}$-irradiation on the activity of the thyroid and pituitary glands of Xenopus laevis (Amphibia) during metamorphosis. f. Z001. 166(2): 159-162. (NSA 26-41175).

Chung, H. W. and G. W. Malacinski. 1975. Repair of ultraviolet irradiation damage to a cytoplasmic component required for neural induction to the anphibian ege. Froc. Natl. Acad. Sci. U.S.A. 72(4): 1235-1239. (Nis 32-6771). (Rana pipiens).

Cloudnan, A. i:., S. P. Stearner and D. Vining. 1948. Proeress report II. Peripheral blood of the frog (Fana pipiens) - effects of exposure to $600 \mathrm{r}$ totalbody $x$-irradiation. III. The effect of $x$-irradiation on larvae amphiblans. pp. 75-77. In: Biol. and lied. Research Div., Quarterly Rept., Argonne Natl. Lab., U. S. ADC report ANL-4205.

Colville, J. E. 1968. The action of $\mathrm{x}$-irradiation on the regeneration field of the adult newt, piemictylus viridescens. Thesis, Tulane Univ., New Orleans, LA. 61 pp. (NSA 23-18096). 
Colwell, H. A. and M. S. Thomson. 1926. On some effects of primary and secondary $x$-rays on the skin of the frog tadpole. Lancet $211(5367), 59-61$. .

Conger, A. D. and J. H. Clinton, 1973. Nuclear volumes, DNA contents, and radiosensitivity in whole-bodyirradiated amphibians. Radiation Res. $54(1), 69-$ 101. (NSA 28-6030).

Cooper, E. I. and D. H. Schaefer, 1970. Bone marrow restoration of transplantation immunity in the leopard frog Rana pipiens. Froc. Soc. Expt1. Biol. Hed. 135: $406-411$. (NIA 25-8620). (60Co irradiation).

Copenhaver, W. N., R. H. van Dyke and R. Rugh. 1960. Effects of $x$-irradiation on embryos at critical stages of heart development. Yale J. Blol. Hed. $32(6)$, 421-430. (NSA 14-23992). (Amblystoma punctatum).

Craft, T. J. 1963. Spme effects of $\mathrm{x}$-irradiation on the utilization of $\mathrm{C}^{14}$-labelled I-tyrosine and melanin production in Rane pipiens tadpoles. Thesis. The Ohio State Univ., Columbus. 72 pp. (NSA 18-27205).

Craif, D. I., J. S. Kirby-Smith and J. N. Dent. 1956. iilotic inhibition and chromosome breakage in salamanders of the genus Gyrinophilus. Trans. Am. liicroscop. Soc. 75: 234-241. (NSA 10-9930).

Curt1s, W. C., J. A. Cameron and K. C. i.ills. 1936. Exogastrulation in amphibia after $x$-ray exposure. Science $83(2154): 354$.

Czech, H., R. Czech and H. J. Schmermund. 1950. Comparative studies of the effect of particles, electrons and $x$-rays on the cornea of salamander larvae. Strahlentherapie 81:187-192. (Also1 U. S. AEC trans l. AEC-tr-3472). (NSA 13-1892).

Dah1, B. 1936. Die Gefassreation der Schwimmhaut des Frasches (Rang temporarta) nach Rontgenbestrahlung. Acta Radiologlca 17(3): 275-283.

Dalcq. A. 1930. Interpretation cylotogique des effets eur la eastrilation de l'irradiation d'un les gametes chez Rene fuscs. Compt. Rend. Soc. Biol. 104, 10551058 . 
Dawsor, W. W. and H. Jiederwohl. 1965. Functional alternation of visual receptor units and retinal Timments by $x$-irradiation. Radiation Res. 24(2): 292-304. (NSA 19-15182). (Iimulus polyphemus, Rana catesbiana).

Debenedettj, A, V. Grossi and A. Lucaroni, 1969. Comparative eitecto of $x$-rays and visible light on the reconstitution of the early potentials (ERF) of the isolated frog eye previously abolished with severe light exposition. Boll. Soc. Ital. Biol. sper. 45: 1371-1373. (In Italian) (NSA 25-27004).

De Cesaris, C. I. 1958. Dipeptidase in amphibian embryos, treated with x-rays. Arch. Sci. Biol. (Bologna) 42(3): 205-2.22.

Uent, J. N. 1949. Effects of $\mathrm{P}^{32}$ on regenerating amphibian tissues (abstr.). Anat. Record 103, 439. (MSA 3-21).

Dent, J. N. 1969, Effects of graded doses of gamma radjation on transplanted pituitary glands in the cpotted newt. Radiation Res. 38(1): 223-229. (iNSA 23-50852). (Triturus viridescens).

Je Sha, D. L. 1971. Participation of $x$-rayed cells in a regenerate induced on an $x$-rayed limb of the salamander, Triturus viridescens. Thesis, Tulane Univ., New Crleans, LA. $78 \mathrm{pp}$. Untv. Miicrofilms Order No. 71-20,218). (NSA 25-58103).

Di Grande, F. 1968. Post-metamorphic development of the gonarls and Bidder organs in young Bufo bufo panirradiated with $x$-rays. Atti Acad. Naz. Lincei rend. Cl. Sci. Fis. liat. Nat. pp. 437-442. (In italian). (NSA 24-844).

Dolgov, E. C. 1962. The effect of toad skin gland secretion on the permeability of tissues to vital stains after their exposure to experimental acute radiation. Bul1. Expt1. Blol. Hed. (USSR) 52(10): 1147-1150. (English transl.). (NSA 16-20157).

Donaldson. D. J. 1972. Pffects of $x$-irradiation on lens regeneration in adult Triturus viridescens. Anat. Record 172(1), 45-55. (NSA 26-25861). 
Donnelly, G. li. and A. H. Sparrow. 1963. Laree chromosomes: The somatic and meiotic chromosomes of Amphiuma. Brookhaven Natl. Lab; U. S. AEC report BNL-7596. 25 pp. (NSA 19-2060): (Nientions radiosensitivity).

Jomelly, S. H. and A. H. John. 1964. Radiosensitivity of the salamander Desmognathus (abstr.). Genetics $50(2), 244$.

Dubis, K. and 2. Srebro. 1970. Wiorpho-functional study of hypothalamic neurosecretion. VI. The effect of locally administrated $x$-irradiation in Rana temporaria and Rana esculenta. Folia Biol. (Krakow) 16:247252. (NSA 25-8764).

Duryee, $W$. 1947. The effect $c_{I} x$-rays on chromosomes and nucleoli in ovarian eges of the salamander, Triturus pyrrogaster (abstr.). Biol. Bull. 93(1): $206-207$.

Duryee, if. $\bar{\kappa}$. 1949. The nature of radiation injury to amphibian cell nuclel; J. Natl. Cancer Inst. 10: 735-796. (NSA 4-2516).

Farberoy, A. I., 2. A. Sokolova and V. V. Popoy. 1965. $\mathrm{X}$-irradiation influence on frog retina. Radiobiologiya $5(2)$ : 319-320. (English transl. AEC-tr6599). (NSA 19-28087).

Farberov, A. I..G. V. Barybina and V. V. Popov. 1972. iffect of $x$-radiation on the pigment epithelium and ganglionic cells of tadpole retina (Rana temporaria). Doklady Akad. Nauk SSSR 206(4): 1014-1017. (In Russian) (NSA 28-8463).

Fimian, w. J., Jr. 1959. Leucocyte inflltration in localized regions of $x$-rayed amphibian limb tissues. Exptl. Cell Res. 16(2): 418-420.

Foxon, G. E. H. 1965. The use of $x$-rays as a research instrument: Problems in animal biology. Proc. Roy. Soc. Med. 58, 164-165. (NSA 19-32002). (Comments on studies on frogs and lizards; fosail fish).

Frledman, G. B., H. bi. Jiccurdy and F. T. Algard. 1970. kesponse of newt larvae to $x$-irradiation. Can. J. Zoo1, 48, 1017-1021. (NSA 25-16350). (Taricha torosa). 
Writz Higeli, H. 1958. Radiation chimaeras and parabiosis.: trahlentherapie 106(3): 378-390. (In German) (rition alpestres).

Gaffey, C. T. 1962. Hioelectric effects of high energy irradiation on nerve. pp. 277-296. In: Response of the Vervove isystem to Ionizing Radiation. Academic jress, London. ( $T$. J. Haley and $R$. S. Snider, eds.). (NEÁ 16-23486). (FrOE).

.affey, C. T' 1970, L'lectrophysiologic responses of sciatic nerves exposed to $200-\mathrm{kV} x$-rays and $47.5-$ liev protons. Advan. Biol. Hed. Phys. 13: 351-371. (NEA 26-23104). (Frog).

Garfey, C. T. 1971. The response of maximal and submaximal action potentials from frog sciatic nerve to 200-kV x-rays. Radiation Res. 45(2), 311-325. (NSA 25-26993).

Calkovsknya, K. F. 1951. Recovery of function of denervated limbs of axoloti following $x$-irradiation. Doklady Akad. Nauk SSSR 81: 945-948. (In Russian) (NEA 6-3496).

Calkovskaya, h. F. 1952. Stimulating effect of $x$-rays on the process of regeneration of peripheral nerves. Doklady Akad. Nauk SSSR 87, 677-679. (In Russian) (NSA 7-4009). (Axolot1).

Gallien, I. 1969. Provoked chromosome anomalies and mutations in amphibians. Annee Biol. 8, 319-33I. (In French) (NSA 24-48492). (Includes ionizing radiation).

iallizn, I. and li. Labrousse. 1962. Radiosensitivity to neutrons of fertilized eges of urodele, Pleurodeles waltlii lichah. Compt. Rend. $255(2) ! 371-$ 373. (In French) (NSA 16-28776).

Gallien, I., b. Labrousse and J.-C. Iacroix. 1963. Chromosomic aberrations associated with the hypomorphoses after $x$-irradiation of the egg in the amphibian urodele pleurodeles wattii vichah. Compt. Rend. $256(25): 5413-5415$. (In French) (NSA 17-33651). 
Gerasimova, G. K. 1963. Ionizing radiation effects on the mechanism of adaptation to rising temperature in the surrounding media. Radiobiologiya $3(5): 711-$ 715. (English trans1. AEC-tr-5438). (NSA 18-23307). (Frog).

Gilman, P. K. and F. H. Baetjer. 1904. Some effects of the roentgen rays on the developnent of embryos. Am. J. Physiol. 10(5): 222-228. (Amblystoma).

Golichenkov, V. A., V. V. Popov and E. B. Vsevolodov. 1964. Data on experimental, radiation-induced cataract in frogs. Doklady Akad. Nauk SSSR I54(6): 1458-1461. (In Russian) (NSA 18-23268).

Goss, R. J. 1957. The effect of partial irradiation on the morphogenesis of limb regenerates. J. liorphology 101(1): 131-148, (Triturus viridescens).

Grayevskiy, Ye. Ya. and Ye. G. 2inov'yeva. 1956. Radiosensitivity of pituitary glands in total body irradiation of amphiblans; Doklady Akad. Nauk SSSR 110: 379-382. (In Russian) (NSA 11-1738).

Griffin, C. S., D. Scott and D. G. Papworth. 1970. Influence of DNA content and nuclear volume on the frequency of radiation-induced chromosome aberrations in Bufo species. Chromosoma 30, 228-249. (NSA 256684).

Gronskaya, N. F. 1963. Relationship of the development of radiation damage and repair on the regenerative activity of tiasues of Rapn temporipia tadpoles. Byull. Eksper. Biol. Mied. 551100-112. (English transl. pp. 108-112). (NSA 18-19781).

Gronskaya, N. F. 1965. Reactions of tadpole tissues to $x$-radiation during starvation conditions. Radiobiologiya $5(6), 850-854$. (English transi. AEC-tr-6603). (NSA 20-10676).

Guha, T, and M. I. De. 1973. Rediation-induced alteration in toad erythrocyte and hemoglobin. Proc. Indian Nat. Sci. Acad. Part B 39(4), 506-51I. (NSA 31-14390).

Guha, T. and M. I. De. 1974. Ifortality of the toad Bufo melanostictus after whole-body $x$-irradiation. Intern. J. Radiat. Blol. 26(1), 77-80. (NSA 31-810). 
Hajnal-Papp, Mi. and A. Niedetsky. 196?. Effect of ionizing radiation on the center of automatism of frog heart. Acta Biochim. Biophys. (Budapest) 2: 199204. (NSA 22-15059).

Hamilton, I. 1969. Changes in survival after $x$-irradiation of Xenonlis embryos at different phases of the cell cycle. Radiation Res. 37(1): 173-180. (NSA 23-16414).

Hartman, A. 1920. Uber der Einwirkung von Rontgenstrahlen auf das Blut und das blutbildende Gewebe von Rana temporaria - larven. Arch. F. Entwicke. d. crg. $47: 131-209$.

Henshaw, P. S. 1943. Peculiar growth lesions in frogs induced by irradiation of sperm cells with $x$-rays. J. Natl. Cancer Inst. 3(4) \& 409-417. (Rana pipiens).

Hohn, A. 1955. The effect of $x$-radiation on the larvae of Xenopus. Oncologia 8(3), 273-289. (NsA 9-6577).

Holan, I., A. Rosenberg, I, G. Russy, L. Diacu and A. Bozac. 1963. The effect of $\mathrm{P}^{32}$ on the early development phases of Triturus vulgaris eggs. Finiol. Normala Fathol. (Bucharest) 9: 169-173. (In Rumanian) (NSA 18-31161).

Fughes, A. F. W. and J. A. F. Fozzard. 1961. The effect of irradiation on cell degeneration among developing neurones in Xenopus laevis. Brit. J. Radiol, 34 (401): 302-307. (NSA 15-19162).

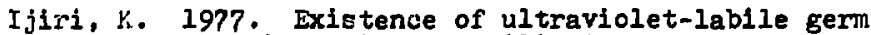
cell determinant in unfertilized eggs of Xenopus laevis and its sensitivity. Dev. Biol. 55(1), 206211 .

Ijiri, $x_{i}$. 1979. X-ray effect on the development of Xenophs laevis embryos - with special reference to primordial cells. J. Radiat. Res. 20(1), 133-136.

Isomaeki, A. H., R. Li, Bergstroem and E. Kivalo. 1962. Ultrastructural changes in the sensory nerve fibers in the skin of the frog (Bnng temporaria) after circumscript Irradiation with Fo2I0 alpha particles (5.3 Hev). Acta Pathol. Microbiol. Scand. 54 190202. (NSA 16-20134). 
Ivanitskaya, A. F. 1956. Reaction of axolotl cell elements to the total $x$-radiation. Izvest. Akad. Nauk SSSR (Biol.) (5), 85-97. (In Russian) (NSA 1l-1939).

Ivanitskaya, A. F. 1961. A microcinematography method in the investigation of the effect of $x$-rays on cells. Pathol. Biol. (Semaine Hop.) 9(7/8), 842-843. (In English) (NSA 17-21542). (Amblystom mexicanum).

Jakowska, S., R. F. Nigrelli and A. H. Sparrow. 1954. Iocal cell responses to induced skin infection in Triturus viridescens after whole-body irradiations (abstr.). Radiation Res. 1(6): 569 .

Jakowska, S., R. F. Nigrelli and A. H. Sparrow. 1958. Radiobiology of the newt, Diemictylus viridescens, hematological and histological effects of whole-body $x$-irradiation. Zoologica $43(4): 155-160$. (NSA i37460 ).

Jakaoska, S., R. F. Nigrelli and A, H. Sparrow. 1961. Effects of chronic gamma irradiation on adult newts, Diemictylue viridescens (abstr.j). Am. zoologist l: 361-362.

Jaylet, A. and C. Bacquier. 1967. Heterozygous chromosomal aberrations in the viable offspring of $x$-irradiated male newts (Pleurodeles waltii lichah.). Cytogenetics 6: 390-401. (In French) (NSA 22-23645).

Kaack. B. 1970. Effect of beta irradiation on oxygen consumption in the frog sciatic nerve. Radiation Res. $42(2)$ : 405-412. (NSA 24-31845). (Rana Dipiens).

KaO, H. 1965. Aytoradiographic research on the incorporation of $\mathrm{Na}_{2} 3 \mathrm{~S}_{4} \mathrm{SO}_{4}$ in the regenerating limb of the axolotl (Amblyatoma mexicanum) after $x$-ray irradiation. Shih Yen Sheng ivu Hsueh Fao 10, 285-297. (In Chinese) (ISA 21-6429).

Kaschenko, I. A. 1962. Radiation damage to the ovulation mechanism in the frog. Radioblologiya $2(6), 868-872$. (English transl. AEC-tr-5433). (NSA 17-15743).

Kaschenko, I. A. 1963. Changes in the anterior hypophysis in irradiated frogs. Radioblologiya 3(1), 76-80. (English transi. AEC-tr-5434). (NSA 17-30341). 
Kashchenkc, I. A. 1971. Radiation reaction of the adenohypophysis-gonads system in cold-blooded animals. 'l'r. Folyar. Nauch.-Issled. Proekt. Inst. Morsk. Ryb. Khoz Okeanogx. (29) , 135-158. (English transl. AECtr-7418). (NSA 27-27949). (Grass frog).

Kassem. I. A. A. 1967. The production of haploid/diploid chimaerae of zenopus laevis larvae oy irradiation. Froc. Eeypt. Acad. Scî. 20: 19-22. (NSA 22-49322). (Ultraviolet radiation).

lsasturi Bai, A. R. and L. Dilli. 1974. Effects of radiations on the rate of regeneration in Homalozoon vermiculare (Stokes) and Urostyla. Indian J. Exptl. Biol. 12(4): 343-345. (NSA 31-14400).

lemp, N. E. 1962. Alterations in frog skin after heavy gamma irradiation. pp. vv-3. In: Vol. 2 Electron Hicroscopy. Academic Press, NY. (NSA 16-31419).

Kharlampovich, S. I. and V. A. Culyayev. 1967. Electron microscopic changes in the thyroid gland in local irradiation. Fed. Kadiologiya 12(4):33-36. (In Russian) (NiA 2l-28610). (TrOE).

limovskaya, i. D. 1962. Effects of ionizing radiation on the function of ciliated epithelium in frog's Fullet. Radiobiologiya 2:222-227. (In Russian) (Nis 16-28809).

Kiortsis, V. and A. Droin. 1958. The importance of the spinal cord durine regeneration of the larval tail of Siglamandra galamandra Laur. Arch. Sci. (Geneva) $11(2), 235-245$.

Klimovskaya, L. D. 1962. Effect of ionlzing radiation upon the function of ciliated epithelium of frog es ophagus. Radiobiologiya $2(2): 222-227$. (Enelish trans 1. AEC-tr-5429).

Kraft, A. V. 1968. Iarval form and visceral situation in the newt (Triturus alpestris) after one-sided UV irradiation of neurulae and postneurulae. Arch. Entwicklungsmech. Crgan. 160,259-297. (In German) (Niti 22-45E78).

Krifer, I. A. and 0. Ni. zorina. 1959. The effect of $x$-rays on the unilateral permeability of froe skin. Biophysics (USIR) (Enelish trans1.) 4, 88-94. (NSA 14-9338). 
Krobel, W. and G. Krohm. 1959. The effects of low radiation doses on the signal production and propagation properties in frog nerves. Atomkernenereie $4(7 / 8)$ : 280-286. (In German).

Kroebel, W. and K. Vanselow. 1962. Investigation of the influence of ion dose rates on the radiation effects on the ischiadicus of frogs. Atomkernenergie 7(12): 464-470. (In German) (NSA 17-7816).

Kuzin, A. K. and F. F. Plinayev. 1966. Fostirradiative modification of radiation damage in frogs (R. ridibunda). Radiobiologiya 6(5): 690-692. (English transi. AEC-tr-6774). (NSA 21-10933).

Kuzin, A. M., I. V. Slozhenikina and V. L. Migushina. 1971. Study of radiosensitivity of thyroxine induction of urea-forming enzymes in Rana temporaria tadpoles. Radiobiologiya 11(5), 754-757. (English trans 1. AEC-tr-7306). (NSA 26-38676).

Iacroix, J, C, and $\mathrm{K}$. T. Loones, 1971. X-ray induced fragmentation of the organizer of a lampbrush chromosome differentiation in Bleurodeles watili. Chromosoma 36(1), 112-118. (In French) (NSA 2625852).

Lakatos, T. 1967. Effect of visitle light and ultraviolet rays on the stimulus threshold of frog muscle sensitized by eosin. Acta Biochim. Biophys. (Budapest) 2: 191-198. (NSA 22-17047).

Landreth, H. F., P. B. Dunaway and G. E. Cosgrove. 1974. Effects of whole-body gamma irradiation on various life stages of the toad, Bufo woodhousei Fowleri. Radiation Res. 58(3), 432-438. (NSA 30-9887).

Lappenbusch, W. I. 1969. The effect of dimethyl sulfoxide (Diso) on the radiosensitivity of the rough.skinned newt (Taricha Exanulosa). Thesis, Cregon State UnIv., Corvalis. 132 Pp. (NSA 24-34647).

Lappenbusch, w. I. 1970. Effect of circadian rhythm on the radiosensitivity of the rough-skinned newt (Taricha grinulose). J. Radiat. Res. 11, 134-137. (NSA 25-32570). 
Lappenbusch, W. L. and D. L. Willis, 1969. The effect of dimethyl sulfoxide (DWSO) on the radiosensitivity of the rough-skinned newt (Taricha eranulosa) (abstr.). Radiation RES. 39(2): 553 .

Iappenbusch, W. L. and D. L. Willis. 1970. The effect of dimethyl sulfoxide on the radiation response of the rough-skinned newt (Taricha granulosa). Intern. J. Radiat. Biol. 18(3): 217-233.

Iappenbusch, $W$. L. and J. H. Ward. 1973. Synergistic bio-effects of oil and irradiation in an aquatic organism, Taricha Eranulosa. Bull. Environ. Contam. Toxicol. 9(2): 75-79. (NSA 33-3250).

laschi, R. and A. Abbati. 1960. Early vascular changes following $x$-irradiation. Rass. Intern. Elettron. Nuc1. 7: 5 Congr. Nucl.. Kome, 1960, 3, 445-475. (NSA 17-37123). (Comments on frog).

Lazard, L. 1959. Influence of 'neutral' grafts on the regeneration of extremities of amblystoma. Compt. Rend. 249(18): 1819-1920. (Irradlation).

Lazard, L. 1965. Regeneration of irradiated members in axolotl, induced by grafts of testlcle. Compt. Fend. 260: 1277-1279. (In French) (NSA 19-21899).

Iazard, I. 1967. Restoration of regenerative capacity in irradiated axolotl limbs by erafts of different heterotopic tissues. J. Embryol. ixptl. Horphol. 18: 321-342, (In French) (NSA 22-52010). .

Lazard. I. 1973. Development of transplanted gonads in axolotl limbs. Effects of irraciation and amputation of the host limb. Compt. Rend. D276(10), 1601-1604. (In French) (NSA 28-21750).

Lebez, D., M. Antonijevic and K. Furlan. 1965. Changes in the composition of frog serum proteins after wholebody irradiation. Nuklearni Inst. "Joz of Stefan," Ijubljana (Yugoslavia). 3 pp. (NSA 20-18243).

Lebez, D., in. Antoni jevic and $M$. Furlan. 1966. Studies on the nitrogen metabolism in Irog 11 ver after wholebody irradiation. $v$. Changes in the composition of froe serum proteins after whole-body irradiation. strahlentherapie 130: 437-439. (NSA 20-42787). 
Leseler, H. A. 1959. Low-level $x$-ray damage to amphibian erythrocytes. Science 129(3362): 1551-1553. (NSA 13-14211).

Lessler, Bi. A. and F. Hi. Herrara. 1961. Electron microscope studies of $x$-ray damage to frog blood cells (abstr.). Radiation Res. 14(4), 482, abstr. 93.

Lessler, H. A. and F. li. Herrera. 1962. Electron-microscope studies of $x$-ray damage to frog blood cells. Radiation Res. 17(2): 111-117. (NSA 16-26821).

Light, A. E. 1935. A hietologic study of the effects of $x$-rays on frog skin. Radiology 25(6): $734-738$.

Iiotti, F. ऽ. 1959. Influence of cobalt salts on the mortality caused by $x$-rays in the larvae of Bufo vulgaris. Spermentale log(1): 87-99. (In Italian).

Iischi, G. and A. Pacciardi. 1952. iction of $x$-rays on the cardian function of Bufo vulearis. II. viectro. cardiographic observations. Radioterapia Radiobiol. e Fis. Wed. 4, 308-314. (In Italian) (NSA 6-3166).

Litschko, Ye. Ya. 1932. Further observations on the effect of $x$-rays on regeneration in axolotl. Compt. Rend. Akad. Nauk UR's' A3(1):65-70, 1 pl. (In Russian).

Iuther, H. 1939. Die strahlenwirkung auf Amphibiahaut vor und nach lietamorphose. Naturwissch. 27(43): 713-720.

Iuther, 1940. deitere Untersuchungen uber das Verhalten der zellteilung in der Haut rontgenbestrahler Salamander-larven. Strahlentherapie 68(2): 185205.

licCurdy, H. 1.1., F. T. AlEard and G. B. Friedmann, 1974. Responses of metamorphosing Tarichi torose to $x$-rays . Can. J. Zool. 52(6):671-676. (NSA 30-24317).

I:CGregor, J. H, 1908. Abnormal development of frog embryos as a result of treatment of ova and sperm with roentgen rays. Science $27(690)$, 445-446. 
Jiangold, O. and T. Peters. 1956. Uber die Wirkung Eleicher Rontgendosen auf verschidene Stadien der Entwicklung von Triton alpestris. Beitr. Path. Anat. $116: 480-498$.

Manoylov, S. Ye. 1959. Importance of the ionization of iron-containing compounds during $x$-irradiation of an organism. Froc. Ist All-Union Conf. Radiation Chem. Noscow, Jt. 4. pp. 189-191. (In Russian) (NZA 13-22118). (Frog heart).

Sianoylov, S. Ye. and K. F. Ivanov. 1955. Some characteristics of the biological activity of penetrating radiation. Doklady Akad. Nauk SSSR 105(1): 180-181. (Frog heart).

i.anoylov, S. Ye.. A. V. Lazovskaya and V. A. Orlov. 1956. Effects of $x$-rays emitted from various anodes upon the work of isolated heart of a frog. Doklady Akad. Nauk ESSR 110, 125-128. (In Russian) (NSA 11-1737).

itarin, A., C. Weneghini, S. Wezzanotte and U. Scarpis. 1960. Considerations on the changes in the blood capillaries after ionizing radiations. II. Histologic and histochemical study of the blood capillaries of the frog tongue after single exposure to $x$-rays. Riv. Anat. Patol. Oncol. 18(5):606-622. (In Italian) (NSA 17-23194).

hartin, W. S., R. C. Grubbs and H. A. Lessler. 1956. Effects of low-level $x$-irradiation of axygen consumption of bullfrog erythrocytes. Am. J. Physiol. 18? (3). 505-508. (NSA 11-4231).

ilaurav'yev, H, N. and A. B. Tsypin. 1967. Action of gamma rays of $60 \mathrm{Co}$ on the automatic activity of the lymphatic hearts of the frog. Doklady Akad. Nauk SSSR 17?: 479-482. (English transl. pp. 799-802). (NSA 22$31132)$.

liedvedev, 2h. A. and I. A. Chaban. 1968. The effect of ionizing radiation on the RNA synthesis in the nucleated erythrocytes of tadpoles and frogs. Teitologiya 10(12): 1569-1579. (In Russian) (NSA 23$12024)$. 
ilelnertz, T. 1963. An investigation of cell division activity in Axolotl larvae and larvae of Triton punctatus, and also experiments with irradiation by ultraviolet light and constant electric light. Arch. Entwicklungsmech. Organ. 154:513-525. (In German) (NSA 19-17511).

Meinertz, T. 1963. An investigation of the cell division activity of $x$-irradiated larvae of priton punctatus. Arch. Entwicklungsmech. Organ. 154, 195-215. In German) (NSA 19-15044).

Miceli, R. and G. Prodi. 1957. The effects of roentgen rays on the metachromatic substance of the skin of the axolotl. Radioter. Radiobiol. Fis. ifed. 12(1): $36-42$.

i:ikami, Y., Y, Yoshida, K. Iakano and Y. Suzuki. 1956. Effect of the radioactive rainwater upon the development of Bufo vulgaris eggs. Mie lied. J. (Tsu) $6(1 / 2), 27-39$.

Iiillo, A. and A. Debenedetti. 1964. Changes of the permeability of the isolated frog heart irradiated with $x$-rays. Frotective action of glucose, of cysteamine, and of sodium thiosulphate. Riv. Biol. 57 (suppl. 2): 151-167. (In Italian) (NSA 20-3794).

Furav'yev, [i. N. 1963. A study of certain manifestations of automatism in frog intee tine after whole-body gamma irradiation. Radiobiologi ya 3(4): $540-544$. (English trans1. AEC-tr-5437). (NSA 18-6669).

Wuzheyev and Shitova. 1956. Influence of radon irradiation on the breathing of an isolated frog muscle. pp. 69-77. In: Problems of Radiobiology. (ii. N. Pobedenskiy and $F$. N. Kiseleva, eds.). (Ref. $\mathrm{zh}$. (Biol.) 1956: 71087).

Nadareishvili, K. Sh. and O. I. Saneblidze. 1966. Ionizing radiation effects on contractile functions of frog striated muscles. Soobshch. Akad. Nauk Gruz. SSR 44:741-748. (In Russian) (NSA 21-20048).

Nadareishvili, K. Sh, and O. I. Saneblidze, 1967. The mechanism of radiation-induced contracture of striated muscles. Radiobiologiya $7(2), 214-220$. (English trans1. AEC-tr-688?). (NSA 21-34784). 
Nadareishvili, K. Sh., B. S. Gugushvili and E. D. Kakhiani. 196?. Local ionizing radiation effects on the heart activity in frofs. Soobshch. Akad. Nauk Gruz. SSR 4?: 451-456. (In Russian) (NSA 22-12905).

Nakazawa, K. 1960. Effect of $x$-ray irradiation upon the affinity of bulfrog's sciatic nerve tissue for photoporphyrin. III. liie Igaku 4: 293-314. (NSA 1525885).

Namenwirth, i.. $R, l_{1}, 1969$. Inheritance of cell differentiation during limb regeneration in the axolotl. Thesis, Indiana Univ., Bloomington. $118 \mathrm{pp.} \mathrm{(liniv.}$ licrofilms order No. 70-7484). (NSA 24-51066). (Irradiation).

i.eyfakhy, A. A. 1961. A radiation study of morphogenetic functions of the nucleus during the early development of anurans. Doklady Akad. Nauk SSSR 136(5): 1248-1251. (English trans1. pp. 41-44). (Rana temporaria. E. esculenta, R. ridibunda, Bufo viridis).

Niedetzky, A. 1967. Effect of radiation on isolated frog hearts stopped as a result of $\mathrm{Ca}$ deficiency. Acta Biochim. Biophys. (Budapest) 2:205-210. (INSA 2215068).

Niedetzky, A. and Cs. Lajtai. 1969. Effect of radioactive radiations on the lifetime of sperms. Acta Biochim. Biophys. 4(2): 211-216. (NSA 24-34602). (F'RE).

Nishimura, K. 1967. Influence of $137 \mathrm{Cs}$ and $90 \mathrm{Sr}$ on the Erowth of early stage amphibian eggs. Hie lifed. $\mathrm{J}$. 16: 245-251. (NSA 22-10875).

Nishimura, K. 1967. On the formation of visceral inversion caused by radioactive iron and calcium. Mile i.ed. J. 16, 253-262. (NSA 22-10857). (Bufo).

Nishimura, $K$. 1967. Abnormal formation of visual organs of amphibian larvae induced by radioactive rainwater. ilie Med. j. 16: 263-267. (NSA 22-15049).

Gerpriller, J. C. 1968. The action of $x$-irradiation on the regeneration fleld of the forelimb of the adult newt, Diemictylus vifidescens. J. Exptl. Zool. 168: 403-422. (NSA 23-20346). 
O'Brien, J. F. and W. L. Gojmerac. 1956. Radiosensitivity of larval and adult amphibia in relations to temperature during and subsequent to irradiation. Froc. soc. Expt1. Biol. Hed. 92(1): 13-16. (NSA 10-9939).

Oga, H. 1959. Effects of $\mathrm{P}^{32}$ irradiation on skin and blood vessels. Yonago hed. J. 10(4): 850-865. (Frog).

Ogawa, $Y$. 1968. Growth, differentiation and regeneration. 44. Effects of repeated $x$-irradiation on the formation of the early Triturus embryo. Igaku To Seibutsugaku 76: 81-84. (In Japanese) (NSA 23-48229).

Padoa, E. 1964. Details on the possibility of destr ine the germinal plasma of the egg of Rana esculenta with ultraviolet rays. Boll. Soc. Ital. Biol. Sper. 40, 272-275. (In Italian) (NSA 22-10692).

Fankova, N. V. 1974. Investigation of radiation-induced chromatid aberrations in amphibian lymphocytes in vitro at the $G_{2}$ phase upon the varying doses of x-rays. Genetika 10(5):52-56. (In Russian; Enelish summary). (NSA 30-18869). (Rana temporaria).

Fartskhaladze, N. N. 1970. Study of the survival of frog, embryos subjected to $x$-irradiation at the stage of zygote. Soobshch. Akad. Nauk Gruz. SSR 60, 685-687. (In Russian) (NSA 25-21900).

Patetta Queirolo, M. A. 1964. Skin absorption of the beta rays emitted by a $90_{\mathrm{Sr}} / 90_{\mathrm{Y}}$ source. Acta Cient. Venezolana 15: 26-28. (NSA 19-33791). (Bufo marinus L.).

Patt, H. and N. Swift, 1948. Influence of temperature on radiation to frogs. Am. J. Physiol. 155(3): 388393.

Perri, T. 1950. The biologic action of $x$-rays on embryos of amphibians. Experiments of transplantation. Riv. Bio1. 42, 119-154. (In Italian) (NSA 4-5348).

Ferri, $T$, 1959. The effect of $x$-rays on the larvae of the anura amphibia. Grafts of joints and administration of thyroxine. Atti Accad. Naz. Iincei. Rend. Classe. Sci. Fis. Mat. e Mat. $27(8), 259-263$. (In Italian) (NSA 14-14677). 
Feters, T. 1955. Development of en unsegmented salamander embryo after treatment with x-radiation in combination with oxygen deficiency, cold, and hydrocyanic acid. Strahlentherapie 98, 628-639. (In German) (NSA 10-2591).

Peters, T. 1959. Growth damageg at various doses in salamander larvae after irradiation in incipient food absorption stage. Strahlentherapie 108: 383402. (In German) (NSA 13-11590).

Peters, T. 1960. The effects of $x$-rays on fertilized ege cells of Triton alpestris with special emphasis on the effects of snall doses and less damage. Strahlentherapie 112(4), 525-542. (In German).

Piatt, J. 1962. Comparative radiosensitivity of foreiimb and hindlimb primordia in amblystoma punctatum. J. Expt1. 2001, 150(2), 143-153. (NSA 17-19851).

Piatt, J. 1962. The effect of temperature upon the development of $x$-irradiated ear grafts in Amblystoma. J. Expt1. 2001. 149(1): 59-73. (NSA 17-33681).

Piatt, J. 1964. A summary study of direct and indirect radiation damage upon the developing ear in Amblystoma. J. Expt1. Z001. 156(3): 331-343. (NSA 19$8864)$.

Fiatt, J. 1964, Development of the ear in $x$-irradiated parabionts of Amblystoma. J. Exptl. Z0ol. 155(1): 117-128. (NSA 18-25148).

Piatt, J. 1966. X-irradiation on lateral-line primordia in Ambligstoma; J. Exptl. Z001. 162(2), 193-207. (NSA 21-13037).

Piatt, J. 1968. Dessociability of developmental processes in the morphogenesis of the ear in Amblystoma. as revealed by $x$-ray damage. Anat. Record $160(1)$ : 143-151. (NSA 22-40921).

Piatt, J. and A. Raventoss. 1953. Transplantation of $x$-irradiated tissues in embryonic amblyatoma. $J$. Ixpt1. 2001. 124(1), 167-197. 
Pick, J. 1965. The fine structure of sympathetic neurons in $x$-irradiated frogs. J. Cell. Biol. $26(2), 335-351$. (NSA 19-42285).

Pletsch, P. and A. K. Bruce. 1965. The sienificance of post-irradiation erowth in regenerating limb and tail olas temas of Amblystoma larvae. J. Cell. Comp. Physio1. $66(2$, Part I): 243-249. (NSA 20-6837).

Pogany, G. C. 1971. Effects of sperm ultraviolet irradiation on the embryonic development of Rana pipiens. Develop. Biol. 26(2): 336-345. (NSA 26-15477).

Pogosyan, R. I. 1962. The sensitivity of skin chromatophores to the lonizing radiation. Byull. Eksptl. Biol. 1 Med. 53, 82-84. (In Russian) (NSA 16-23444). (Frog).

Polezhayev, I. V. 1966. Mechanism of recovery of the regenerative capacity inhibited by $x$-irradiation. Izv. Akad. Nauk SSSR, Ser. Biol. (2): 254-265. (In Russian) (NSA 20-29038).

Folezhayev, I. V. 1966. Restoration of regenerative capacity suppressed by $x$-irradiation. Izv. Akad. Nauk SSSR, Ser. Biol. (1), 37-58. (In Russian) (NSA 20-18337).

Polezhayev, I. V. and S. Ya. Tuchkova. 1968. Transplantation of heterologous tissue as a means of restoring axolotl limb regenerability after depression by $x$-irradiation. Doklady Akad. Nauk SSSR 180, 754757. (English transl. pp. 277-280). (NSA 22-45688).

Polezhayev, I. V., N. A. Teplits and S, Ya. Tuchkova. 1962. Regeneration of axolotl entremitiea depreseed by $x$-rays and prevention of $x$-ray induced ulcers. pp. 210-216. In: Recovery Processes in Radiation Injuries. Meeting of the Acad. Med. Sc1. USSR. (N. A. Kraevskiy and A. V. Iabedinskiy, eds.). Hoscow, Atomizdat. (In Russian) (NSA 18-38969),

Folezhayev, I. V., N. A. Tepllta and S. Ya. Tuchkova. 1962. The role of proteins and of the nucleic acids in restoring the regenerative capacity of the extremities in salamanders (axolotls), which had been suppressed by $x$-ray irradiation; Doklady Akad. Nauk SSSR 144, 930-933. (In Russian) (NSA 16-26794). 
Polezhayev, I. V., N. A. Teplfts and S. Ya. Tuchkova. 1963. Factol.s affecting the restoration of regenerative capacity in the extremities of axolotls (larval salamanders), which had been suppressed by $x$-ray Irradiation. Doklady Akad. Nauk SSSR 150(3), 694697. (English trans1. pp. 690-693). (NSA 17-33665).

Polezhayev, I. V., N. A. Teplits and S. Ya. Tuchkova. 1964. Regeneration ability restored with the aid of nucleic acid in axolotl extremities, inhibited by $\mathbf{x}$-ray irradiation. Doklady Acad. Nauk USSR 159(3): 682-685. (English transl. pp. 798-801). (NSA 19-26118).

Popov, V. V. 1962. Provocation of a radiation cataract by traumatizing an irradiated eye lens. Doklady Akad. Nauk SESR 143, 441-443. (In Russian) (NSA 16-20165). (Frog).

Fopov, V. V. 1962. Ray cataract in the lens of the eye caused by wounding after $x$-irradiation. Nature 194 (4831), 884-885. (NEA 16-20200). (Frog).

Eopov, V. V. 19.3. Protective effect of cystamine on the induction capacity of the irradiated eye. Vestn. liosk. Univ. (biol.. pochv.) (1): 110-111. (In gussian) (NSA 23-48203). (Rang temporaria tadpole).

Fopov, V. V. and A. I. Farverov, 1962, ElectroretinoEram of irradiated eye and induction of the cornea. Iz vest. Akad. Nauk SSSR Ser. Biol. 1, 102-105. (English transl. JPRS-13562). (NSA 16-28673). (Tadpole).

Fopov, V. V. and V. A. Golichenkov. 1964. Resistance of triton lens to radiation and trauma. Nauchn. Dokl. Vysahei shkoly, B101. Nauki (3), 82-86. (English trans1. JPRS-28782). (NSA 19-21866).

Popov, V. V. and V. V. Ul yanova. 1967. Stimulating and depressive effect of $x$-rays on the functional state of the retina and on its ability to induce cornea formation. Doklady. Aknd. Nauk SSSR 177: 728-731. (English trans1. pp. 753-756). (NSA 2233926). (Frog). 
Popov, V. A., O. P. lielikove and Yu. P. Kozlov. 1965. The relation between certain physical and chemical changes in irradiated skin and its ability of rapid transformation into cornee. Doklady Akad. Nauk SSSR (Biol. Sci.) 165: 241-244. (English transl. pp. 724727). (NSA 20-32986). (Rana pipiens).

Popov, V. V., V. A. Gollchenkov, A. I. Farberov and Z. A. Sokolova. 1964. hechanism of acceierated development of radiation cataracts caused by a prick in the irradiated crystalline lens. Doklady Akad. Nauk. SSSR 155(4), 940-943. (In Ruseian) (NSA 13-27109). (FrOg).

Pora, E. A. and St. Nianciulea. 1972. Action of very small doses of radiations on certain enzymes in Rana esculenta. (Periodical not given) 24 (2): $139-142$. (In Rumanjan) (NSA 28-2959).

Fora, E. A., St. Hanciulea and A. Suteu-Rusdea. 1968. The action of very low gamma-ray doses on froe liver tissue respiration during spring recovery. Rev, Roum. Biol. (2001,) 13:193-195. (In French) (NSA 2343875).

Fortela, A., li. Garfunkel, J. Vaccari, A. W. Delbue, F. A. Siewart arit J.C. Perez. 1971. Radiation effects on water permeability and distribution in froe muscle cells. Radiation Res. 47(3):704-715. (NSA 25-55323).

Prasad, K. N. 1968, Necturue maculosus as an experimental animal to study cellular injuries of the irradiated gut in yivo: bionogr. Nucl. hed. Biol. (1): 377-384.

Prasad, K. K. and H. A. Johnson. 1968. Differential radiosensitivity of the hepatic mejanocytes of Amphiuma tridactylum. Radiation Res. 33(2): 403-416. (NFA $22-21580)$.

Fraslicke, 3. and li. Hill. 1959. The effect of a low temperature on the development of radiation injury in frogs. Folia 310l. (Frague) $5,348-354$. (In RusBian) (N.JA 14-4234).

Praslicka, J., J. Helona, J. Havelka and J. 2ieka. 1955. The influance of the simultaneous offoct of $x$-ray irradiation on the mortality of tadpoles. Folia Biol. (Frague) 1 , 375-380. (In Ruse1an) (NSA 13-19789). 
Fuckett, W. 1936. The effect of x-radiation on limb development and regeneration in Amblystoma. $\mathrm{J}$. Diorphol. 59(1), 173-213.

Puckett, $W, 1937$. X-1rradiation and thyrold induced metamorphosis in anuran larvae. J. Exptl. Zool. $76(2): 303-323$.

Wueirolo, H. A. F. 1964 . Cutaneous absorption of -rays emitted by a $90_{S r} / 90_{Y}$ source. Acta cient. Venezolana 15: 26-28. (In Spanish) (NSA 19-12915). (Bufo marinus).

Rattazzi, 11. 1964. Free amino acids in the embryos of Rang esculenta and Bufo vulgaris. Quantitative determination in normal ova and in ova fertilized with irradiated sperm. Att1 Accad. Nazl. Lincei, Rend., Cl. Sci. Fis. Mat. Nat. 36, 75-85. (In Italian) (NSA 19-12978).

Reyss-Brion, H. 1962. Modifications of the competence of the ectoderm of the gastrula of batrachia after irradiation with $x$-rays. Compt. Rend. 225: 10131014. (In French) (NSA 17-5807).

Feyss-Brion, 15. 1963. On the strustures differentiated from $x$ irradiated amphiblan ectoderm. J. Embryol. Expt1. Morphol. 11(4), 649.657. (In French) (NSA 18-19649).

Reyss-Brion, $M$, 1964. The effect of $x$-rays on the respective potentialities of competent zctoderm and its natural inducer in the early amphibian gastrula. Arch. Anat. Microscop. Morphol. Exptl. 53; 397-465. (In French) (NSA 19-33809).

Richter, 1 . 1968. The effect of $x$-radiation on the regenerative ovents in the brain of Ambiystoms mexicanum. 2. Mikrork.-Anat. Forsch. $79 t 31 \mathrm{C}-341$. TIn German) (NSA 23-48193).

Rollason, G.S. 1949. X-radiation of eggs of Rang pipiens at various maturation stages. Blol. Bull. $97(2)$ : 169-186. (NSA 4...33).

Rondanelli, E. G., A. Trenta, V. Vannini, E. Hagliulo and G. Gerna. 1965. Pseudo-aml toses provoked by $x$-rays in erythropolotic cello in vitro. Nouvelle Rev. Franc. Hematol. 5, 213-220. (In French) (NSA 1943826). (Bioles rulerrts). 
Rondanelli, E. G. et al. 1967. Morphogenesis of the cells at several nuclei by action of $x$-radiation. Study in contrast of phase on the erythropoietic cells to the living state. Exptl. Cell Fes. 47, 222-228. (In French) (NSA 21-43509). (Triton spleen).

Rose, F. C. and S. M. Rose. 1965. The role of normal epidermis in recovery of regenerative ability in $x$-rayed limbs of Triturus. Growth 29. 361-393. (NSA 20-20465).

Rose, F. C. and S. H. Rose, 1967. Nerve penetration and regeneration after $x$-rayed limbs of Triturus viridescens were covered with un-x-rayed epidermis. Growth 31: 375-380. (NSA 22-43451).

Rose, F. C. and S. M. Rose. 1974. Regeneration of aneurogenic limbs of salamander larvae after $x$-irradiation. Growth 38(1), 97-108. (NSA 29-29818). (Amblystoma).

Rose, F. C., H. Qunstler and S. H. Rose. 1955. Regeneration of $x$-rayed salamander limbs provided with normal epidermis. Science 122(3178), 1018-1019. (NSA 10521).

Rosen, D. and K. B. Dawson. 1960. Search for immediate effects of x-radiation on frog nerve-muscle preparations. Radiation Res. 12(4), 357-370.

Rosen, D. and K. B. Dawson, 1962, Fall in threshold to electrical excitation of $x$-irradiated isolated frog nerve. Intern. J. Radiation Biol. 5(6), 535-541. (NSA 17-10417).

Fostand, J. 1957. Honstrous frogs and radioactivity. Compt. Rend. 245(14), 1175-1176.

Rowinski, P. 1962. The biological effects of variation of radioactivity of potassium in the perfused isolated heart. Final Report for IAEA Contract No. 52. $35 \mathrm{pp}$. (NP-14664). (NSA 19-12953). (Ran esculenta).

Rugh, R. 1939. Developmental effects resulting from exposure to $x$-rays. I. Effect on the embryo of irradiation of fror speju. Proc. Am. PhIlo. Soc. $81(3), 447-471$. 
Rugh, R. 1949. Some prenatel effects of Amblygtome opacum larvae exposed to $25,000 \mathrm{r}$ x-radiation (abstr.). Anat. Record 103(3): 500-501.

Rugh, R. 1949. The immedlate and delayed morphological effects of $x$-radiations on meiotic chromosomes. Columbia Univ., U. S. AEC report AECU-649 (CUF-3). $20 \mathrm{pp}$. (NSA 4-383). (Iriturus pyrrhogaster).

Rugh, R. 1954. The effect of ionizing radiation on amphibian development. J. Cell Comp. Physiol. 43 (Suppl. 1): 39-67. (NSA 8-5095).

Rugh, R. 1954. X-irradiation of the frog embryo, Gross effects. Columbia Univ.. U. S. AEC repurt NYO-474. $25 \mathrm{pp}$.

Rugh, R. and F. Exner. 1940. Developmental effects resulting from exposure to $x$-rays. II. Development of leopard frog eEge activated by bullfrog sperm. Froc. Am. Fhilo. Soc. 83(5): 607-619.

Rugh, R, and R. H. Van Dyke. 1962. Reactions of the $x$-irradiated embryonic eye in a normal field and vice versa. J. Expt1. 2001. 149:217-231. (NSA 177848 ). (Amblystoma punctatum).

Rugh, R. and R. H. Van Dyke. 1964. The fate and effect of $x$-irradiated neuroblasts (presumptive neural ectoderm) in a normal envi ronment. J. Exptl. 2001. 157 (2): 197-215. (NSA 19-28026). (Amblystoma punctatum).

kuesu, I. G., T. Holan, A. Rosenbere and I. Diaguj; 1961. The influence of radioactive phosphorus ( $P 32$ ) on the growth and differentiation of the tadpoles of Rana temporaria. Acta Anat. $46(3): 233-239$. (INSA 17270727 .

Saakyan, A. G. 1959. Effects of radon mineral water on isolated frog heart subjected to block of tiseue sulfhydryl eroups. Farmakol. i Toksikol. 22, 178182 .

Sambulchi, H. 1964. Effects of radiation on frog eges. I. The development of egge traneplanted with irradiated nuclei or cytop.tasm. Idenfaku Zasshi 39: 259-267. (NSA 19-36006). 
Sambuichi, H. 1966. Effects of radiation on frog eges. II. Diploid and haploid eggs with heavily $\gamma$-irradiated cytoplasm. Embryologia (Nagoya) 9; 196-204. (NSA 21-24623).

Saneblidze, O. I. 1967. Radloinduced contraction of skeletal muscles in frogs. Soobshch. Akad. Nauk Gruz. SSR 47, 457-462. (In Russian) (NSA 22-12904).

Saneblidze, O. I., K. Sh. Nadareishvili and Yu. Ya. Shafir. 1967. Radiation effects on electrical ant mechanical activity of skeletal muscles in frogs. Soobshch. Akad. Nauk Gruz. SSR 45: 499-506. (In Russian) (NSA 21-24616).

Sanides, F. 1956. Die lethale und teratogene Wirkung von Roentgenstrahlen auf ungefurchte Keime und Gaetrulen von Priton alpestris in verschiedenem Milieu. Biol. 201.75: 149-177.

Schaper, A. 1904, Experimentelle Untersuchunger uber En Einfluss der Radium-Etrahlen und der Radiumemanation auf embryonale und regenerative Entwicklungsborgange. Anat. Anz $25(12 / 13), 298-314 ; 25(14 / 15)$, 326-337. (In German). (Rana esculenta, Rena fusca, triton, planaria).

Scheitanov, G. and G. Russev. 1963. Effect of contact of roentgen-irradiated salamander embryos on nonirradiated salamanders. Radiobiol. Radiotherap. 4(2): 159-165. (In German) (NSA 17-33743).

Schine, H. R. and H. Fritz-Niggli. 1954. Balformations of the adult claw frog (Xenopus Inevis Daud) after $x$-radiation in the embryonic stages. Strahlentherapie 94, 147-15I. (In German) (NSA 8-5093).

Schjeide, O. A. and B. A. Allen. 1951. The relation of mitosis to the manifestation of $x$-ray damage in hematopoietic cells of tadpoles. J. Cell. Comp. Physiol. 38(1): 51-67. (NSA 5-28?). (Rana catesbiana).

Schjeide, O. A.. M. J. Jilllard and B. M. Allen. 1953. The effects of $x$-irradiation on the circulating blood cells of the tadpole of Ring catesbiang. Univ. of Calif. at Los Angeles, U. S. AEC report UCLA-24I. (NSA 7-1872). 
Seymour, R. and K. B. Dawson. 1967. Effects of $\mathbf{x}$-rays combined with other agents on the excitability of frog sciatic nerve. Intern. J. Radiat. Biol. 13(2): 171-178. (NSA 22-21568).

Seymour, $\vec{k}$. and K. B. Daweon. 1967. Variation in the response and threshold to electrical excitation of $x$-irradiated isolated frog nerve with dose and doserate. Intern. J. Radiat. Biol, 12(1): 1-11. (NSA 21-36715). (Rana temporaria, Rang pipiens).

Shabadash, A. I. 1960. Cytochemical signs of radiobio.. logical reactivity of the nervous system and their functional significance. Voprosy Teitologii $i$ Cbshchey Fiziologii. pp. 368-381. (English transl. JFRS-12921; CSO: ó905-N). (Frogs and rats).

Shabadash, A. L., S. G. Yenenko and I. V. Orlova. 1963. Cytochemical studies of glycogen in the central servous system of the frog after gamma-irradiation. Arkh. Anat. Gjstol. i Embriol. 44(5): 26-36. (Englieh transl. JPRS-21170 (Del.); O'SS-63-31802 (Dei.)). (NSA 17-37069).

Shoop, C. R. 1975. Effects of ionizing radiation on salamander orientation. Final report. liniv. of Rhode Island, U. S. AEC. report c00-3486-3. $36 \mathrm{pp.}$ (NSA 33-20525).

Sidorova, V. F. 1951. Regeneration of $\mathbf{x}$-ray-irradiated extremity of axolotl on transplantation of unspecific tissues. Doklady Akad. Nauk SSSR 81: 297-299. (In k̃useian) (NSA 6-5943).

sidorova, V. F. 1957. On the causes of regeneration ability loss in the axolotl extremity after $x$-raying. Byull, Eksp. Biol. Ned, 43(2): 215-219, (English transl. pp. 84-89). (NSA 12-9582).

Sinakov, Yu. G., L. M. Poluyektova and V. V. Popov. 1969. Influence of large doses of radiation on the lipid content in the crystaline lens of the grass frog. kadiobiologiya 9(5): 784-785. (Englieh transl. AEC$\operatorname{tr}-7136$ ). (NSA 24-11949).

Skowron, S. and H. Roguski. 1958. Regeneration from implanted dissociated cells. I. Regenerative potentialities of limb and tail celle. Folia biol. (Krakow) 6,163-173. (In English) (Axolotl). 
Smith, I. D, 1966. Role of a germinal plasm in the formation of primordial germ cells in Rang pipiens. Dev. Biol. 14:330-347. (NSA 21-20410). (UV irradiation).

Sokolova, Z. A., A. A. Gusovskaya and V. V. Popov. 1969. Effects of $x$-irradiation on the retina of grass frog tadpoles. Radioblologiya 9(6); 863-867. (English trans1. AEC-tr-7145). (NSA 24-17139).

Sologub, H. I. 1962. Effects of different doses of $x$-ray irradiation on changes of intra-cellular resting potentials of muscular fibres. Vestn. Leningr; Univ., Ser. Biol. (15): 138-145. (In Russian) (NSA 19-24362). (Rana temporaria).

Sparrow, A. H., C. H. Nauman, G. M. Donnelly, D. L. Nillis and D. G. Baker. 1970. Radiosensitivities of selected amphiblans in relation to their nuclear and chromosome vo? nes. Radiation Res. 42(2): 353371. (NSA 24-32195). (Desmoenathus fuscus. Taricha Eranulosa. Amphiuma means. Necturue macuIosus, kana Dipiens, Notophtalmus viridescens, Ambiystoma mexicanum).

Srebro, Z. 1970. Hammalian and frog pars tuberalis in some experimental conditions including $x$-irradiation. Folia Blol. (krakow) 18:335-341. (NSA 25-24365).

Stearner, 3. F. Date? Effects of various doses of $x$-rays on frogs. I. Survival. II. Hematology. III. Hictoloey. pp. 36-39. Ins Blology and Hedical Division duarterly Progress Report. Argonne Natl. Lab., U. S. AEC report ANL -4147 .

Stearner, S. P. 1947. I. Hematology of the frog (Rana pipiens). II. Effect of $1500 \mathrm{r}$ upon the peripheral blood of Rana pipiens. pp. 42-50. In: Biology and INedical Division Quarterly Proeress Resport. Areonne Natl. Lab., U. S. AEC report Aill-4108.

Stearner, E. P. 1948. I. Acute changes following $900 \mathrm{r}$ $x$-irradiation in the peripheral biood of the frog (Rans pipiens). II. Survival. III. Parasites. pp. 38.47 . In: Argonne NatI. Lab.. U.S. AEC report ANI-4163. 
Stearner, S. F. 1950. The effects of $x$-irradiation on Rana pipiens (leopard frog), with special reference to survival and to the response of the peripheral blood. J. Expt1. 2001. 115(2), 251-262. (NSA 5-917).

Stineon, B. D. 1958. Radioprotection of regeneration capacity in urodele larvae. Anat. Record $132(3)$, 510-512.

Stinson, 3. D. 1963. The response of $x$-irradiated limbs of adult urodeles to normal tissue grafts. I. Effects of autografts of sixty-day forearm regenerates. J. Expt1. 2001. 153(1): 37-52. (NSA 18-13499). (Triturus viridescens).

Stinson, 3. D. 1964. The response of $\mathbf{x}$-irradiated limbs of adult urodeles to normal tiseue grafts. II. Effects of autografts of anterior or posterior halves of sixty-day forearm regenerates. J. Exptl. Zool. 155(1): 1-23. (NSA 18-29314).

Stinson, B. D. 1964. The response of $x$-irradiated limbs of adult urodeles to normal tissue grafts. III. Comparative effects of autografts of complete forearm regenerates and longl tudinal half forearm regenerates. J. Expt1. 2001. 156(1): 1-18. (NSA 1913013). (Triturus viridescens).

Strelin, C. S. 1934. The effects of $x$-rays on frog corneal epithelium. Vestn. Rentgenol. I Radiol. $13(1): 98-113$.

Sturges, M. H. and I. Levin. 1921. Influence of radium and $x$-rays on the frog's leucocytes. Proc. Soc. Expt1. Biol. ifed. 18(B): 295-297.

Suzuki, A. 1967. Analysis of the effects of neutron radiation on developine. Triturus embryos. J. Exptl. 2001. 165(1): 111-115. (NSA 22-10877).

Tanaka, N. 1964. Effects of x-ray Irradiation on secondary gill formation and tail regeneration of Branchiura sowerbyi. Part I. Nippon Igaku Hoshasen Gakkai Zasshi 23(11), 1314-1325. (In Japanese) (NSA 19. 21951). 
Tanaka, N. 1966. Effect of fractionated $x$-rays and $\gamma$-rays irradiation on tadpole of amphibia. I. Rana nigromaculata. Nippon Igaku Hoshasen Gakkai Zasshi 26:910-913. (In Japanee) (NSA 21-22753).

Tenaka, N. 1966. The effect of fractionated $x$-rays and $\gamma$-rays on the tadpole of amphibia. II. On the Rhacophorus schlegelii arborea. Nippon Igaku Hoshasen Gakkai Zasshi $26,914-921$. (In Japanese) (NSA 22-28663).

Tanaka, N. 1966. Effects of $x$-rays on the secondary eill formation and the tail regeneration in Branchiura sowerbyi. III. The protective effect of chlorobutanol against $x$-irradiation on tail regeneration in Branchiura sowerbvi. Nippon Igaku Hoshasen Gakkai Zasshi 26, 922-926. (In Japanese) (NSA 2134732).

Tanaka, N. 1966. The protective effects of some narcotic substances against $x$-irradiation in aquatic animals. I. Effects of chlorcbutanol in lar'vae of khacophorus arboreus. Nippon Igaku Hoshasen Gokkai Zasshi 26 , 1001-1011. (NSA 21-41464).

Tanaka, N. 1966. The protective effects of some narcotic substances against $x$-irradiation on aquatic animals. III. Effecte of urethane and changes in concentration of chlorobutanol solution against $x$-irradiation in larvae of Rhacophorus arboreus. Nippon Igaku Hoshasen Gakkai Zasshi 26(8): 1016-1021. (In English) (NSA 22-28552).

Tanaka, N. 1967. The effects of $x$-irradiation on the treated amphibian larvae in 2,4-dinitrophenol and azaid. Nippon Igaku Hoshasen Gakkai Zasshi 26, 1384-1387. (In Japanese) (INSA 21-36644).

Tansley, K., I. H. Gray and F. G. Spear. 1948. A preliminary note on some biological effects of alpha radiation on the frog tadpole. Brit. J. Radiol. 2l(251): 567-570. (NSA 2-33).

Taragov, B. N. 1954. Principles of biological action of radioactive radiation. pp. 3-138. Hoscow, Jiediz. (English transI. PB-11230). (NSA 13-14992). (Includes study on survival of frogs and salamander eges irradiated under different temperatures). 
Teplits, N. A. 1963. Changes in the nucleic acid content in the limbs of the axolotl after irradiation with roentegen rays and restoration of the power of regeneration. Doklady Aked. Nauk SSSR 147(1), 244-247. (Entlish transl. pp. 1312-1314). (NSA 17-7834).

Teplits, N. A. 1964, Variation in the content of nucleic acids in the tissues of axolotl extremities following their $x$-ray treatment as against normal regeneration. Doklady Akad. Nauk SSSR 159(2): 442-445. (English transl. pp. 169-172). (NEA 19-25942).

Tester, J. R., M. A. Ewert and D. B. Siniff. 1970. Effects of ionizing radiation on natural and laboratory populations of Hanitoba toads, Bufo hemiophrys. kadiation Res. $44(2)$ : 379-389. (NSA 25-8628).

Thorton, C. S. 1958. The inhibition of limb regeneration in urodele larvae by localized irradiation with ultra. violet liEht. J. Exptl. 2001. 137(1): 153-179.

'ligyi, J. 1963. The effect of 15-liev electron raye on the activity and excitability of the isolated frog heart. Acta Fhysiol. Acad. Sci. Hung. 24, 129-135. (NSA 18-25098).

TiEyi, J. 1971. Effect of gamma-irradiation on the Ca content of etriated muscles. pp. 403-407. In: Radiation Biophysics, Free Radicals. Vol. II. (E. Broda, ed.). Wiener liedizinische Akademie, Vienna. (NSA 30-588). (Frog).

Tkacheva, G. A. 1968. Ontogenetic dependence of the interrenal gland reaction on irradiation. Byull. iksper. Biol. Med. 65(5), 109-113; (In Russian) (NSA 22-45695). (Anuran amphibia).

Trampusch, H. A. L. 1958. Action of $x$-rays on morphogenetic field. I. Heterotopic Erafts on irradiated limbs. Froc. Kon. Ned. Akad. Wiet. $61,417-420$. (Axolotl).

Trampusch, H. A. I. 1959. New experiments on the effect of $x$-rays on the morpl zgenetic field. Ned. $T$. Geneesk. 103(13), 695-696. (Amphibian). 
Treip, C. S. and G. Divita. 1966. Histopathology of the cerebellum, medulla, and labyrinth of xenopus 1aevis after high doses of total-body acute irradiation. J. Neuropathol. Exptl. Neurol. 25, 296-310. (NSA 21-20094).

Trott, K. -K. 1966. Radiaticn effect of the potential and resistance of frog skin. pp. 125-129. Ini Biophysikalische Probleme der Strahlenwirling. (Biophysical Problems of the Actions of Radiation). (H. Nuth, ed.). Georg Ihieme Verlag, Stuttgart. (NSA 21-22361).

'Prunova, N. M. 1967. Change in the electroretinogram during irradiation. Radiobiologiya 7, 548-552. (NSA 22-15081). (Rana ridibundai Rana temporaria).

Tisypin, A. B. and N. Bi. Irunova. 1964. Reactions of the retina to ionizing radiation. In loth Coner. of the All-Union Paviov Physiological Soc.. Erevan, 1964. Vol. II, No, 2. Tezisy Nauchn. So boshch., Vypusk 2.. Izdatel'stvo Nauka. (E'nglish tranel.. Wright-Patters on Air Force Base. Air Force Systems Command, Foreign Technol. Div, , report FTD-TT-65-48, pp. 590-591). (NSA 19-40359). (Includes frog).

Tuchkova, S. Ya. 1964. Causes underlying the loss of regeneration capacity by salamander extremities. after exposure to $x$-rays. Doklady Akad. Nauk SSSR 158(6): 1420-1423. (English transl. pp. 101-111). (NSA $19-19544)$.

Tuchkova, S. Ya. 1964. Variation in the content of nucleic acids, accompanying cuppresed regeneration of extremities in salamanders following $x$-ray treatment. Doklady Akad. Nauk SSSR 159, 215-218. (English trans1. pp. 791-793). (NSA 19-19546).

Tuchkova, S. Ya. 1965. Histological and histochemical investigation of the restoration of the ability to regenerate limbs in axolotl, suppressed by $x$-ray irradiation. Radiobiologiya 5(2), 207-210. (inglish trans1. AÉC-tr-6599).

Tuchkova, S. Ya. 1966. Role of trauma in the restoration of regeneration capacity in axolotl extremities inhibited by $x$-ray irradiation. Doklady Akad. Nauk SSSR 168: 473-476. (English trans1. pp. 349-352). (NSA 21-8986). 
Tuchkova, $\Xi$. Ya. 1967. Variation in mitotic activity in extremity tissues of axoloti in the case of restored regeneration ability inhibited by $x$-ray treatment. Doklady Akad. Nauk SSSR 172, 222-224. (In Russian) (NSA 2l-34749).

Tuchkova, S. Ya. 1969. Autoradiographic study of DNA synthesis from the inclusion of thymidine-3H during restoration of regenerative ability in axolotl extremities, suppressed by $x$-ray irradiation. Doklady Akad. Nauk SisR 186: 724-72?. (English transl. pp. 452-456.) (NSA 23-50824).

Tuchkova, S. Ya. 1973. Autoradiographic data on the participation of irradiated tissues in the process of axolotl extremity regeneration suppressed by $x$-ray irradiation. Doklady Akad. Nauk SSSR 2IO(4): 986-988. (NSA 28-20178).

Iuchkova, S. Ya. 1976. Participation of irradiated tissues in the formation of a limb regenerate in axolot1. Doklady Akad. Nauk SSSR 228(3): 752-755. (English transl. pp. 243-245).

Tumanishvili, G. D. 1962. Regeneration of tissues under the action of extracts irradiated by $\gamma$-and $x$-rays. Tr. Inst. Fiz. Akad. Nauk Gruz. SSF 8: 109-114. (In Russian) (NSA 17-12117). (Frog, hen).

I'umanishvili, G. D., V. F. Nandzhgaladze and Kh. N. Dzhanelidze. 1964. Effect of ionizing radiation on the stimulation properties of tissue extracts. foobshch. Akad. Nauk Gruz. SSR 33: 549-556. (NSA 19-8917). (Rana ridibunda).

Turska, R. 1971. Fathologic changes in the ultrastructure of hepatocytes in the axolotl (Amblystoma tigrinum Green) under the influence of roentgen rays. Acta lied. Fol. 12(2): 231-233. (NSA 25-58112).

Turska, R. 1971. Pathologlcal changes of ultrastructures of hepatocytes of axolotls after $x$-irradiation. Z001. Fol. 21(1): 91-99. (NSA 26 48269).

Underbrink, A. G., A. H. Sparrow and V. Fond. 1968. Chromosomes and cellular radiosensitivity--II. Use of interrelationships amone chromosome volume, nucleotide content and $D_{0}$ of 120 diverse organisme in predicting radiosensitivity. Kiadiation Bot. $8(3), 205-$ 238. (Includes Chlamvdomonas reinhardi. Rana pipiens, Eugiena Eracilis, Amphiuma, Necturus). 
Ursprung, H., J. Leone and L. Stein. 1968. Blastular arrest and chromosome abnormalities produced by $x$-rays in two amphibians: Rana pipiens and Xenopus laevis. J. Expt1. 2001. 168(3), 379-386. (NSA 23. 24745).

Van Caneghem, P. 1964. Cause of death after irradiation of lower extremities of frogs. Strahlentherapie 125: 441-448. (In German) (NSA 19-7150).

Van der Schueren, G, and J. Bonte, 1958. Disturbance of the ion transport across the irradiated skin of amphiblans. Proc. 2nd Intern. Conf. on the Peaceful Uses of Atomic Enerey 22: 191-200. (NSA 13-6069).

Vanselow, $k$. 1967. Stlidies on short-term recovery processes in the stimulation threshold of peripheral nerve fibres altered by $x$-inradiation. Atompraxis 13: 34-37. (In German) (NSA 21-18123). (Frog).

Vintemberger, $P, 1928$. Sur $I^{\prime e m p l o i ~ d e s ~ r a y o n s ~} X$ en embryologie comme agents de destrustion localisee. Une technique nouvelle pour l'etude de la pontentalite des deux premiers blastomeres dans l'oeuf de la grenouille rousse. Compt. Rend. Soc. Biol. 99(33): 1590-1592. (Frog).

Vintemberger, $P$. 1928. Sur les effects d'application des rayons $X$ localisees soit au protoplasm, soit a la region nucleaire de la cellule. Compt, Rend. Soc. Biol. 99: 1968-1971. (Frog ege).

Vintemberger, P. 1928. Sur les variations de la radiosensibilite au cours des premiers mitoses de segmentation dans 1 oeuf de Rana fusca. Compt. Rend. Soc. Biol. 98, 532-535.

Vintemberger, $P$. 1928. The effects of localized irradiations on one of the two first blastomeres in the egg of the European frog. Compt. Rend. Soc. Biol. 99: 1592-1594. (In French).

intembercer, F. 1930. Sur la resultats d l'application d'ure tres fort dose de rayons $X$ a diverses regions d $l^{\prime}$ oeuf de grenoullle rousee. Compt. Rend. Soc. Biol. 102, 1055-1057. (Frog egg). 
Vintemberger, P. 1933. Suppression of the blastopore in Rana fusca due to irradiation localized to the inferior hemisphere of the blastula, and the theory of the origin of the blastopore and of the embryo. Comp. Fend. Soc. Biol. 112! 809-812. (In French).

Voino-Yasenetskiy, A. V. 1955. Effect of Co60 gamma radiation on the process of ovulation, fertilization, and embryonic development in the frog. Doklady Akad. Nauk SSSR 100, 389-391. (In Russian) (NSA 9-2581).

von Kraft, A. 1968. Situs inversus of the newt (TrituruS alpestris) after UV irradiation of gastrulas. Arch Entwicklungsmech. Organ. 161: 351-375. (In German) (WSA 23-50837).

von Kraft, A. 1969. The enteric situs of the alpine salamander (Triturus alpestris) after UV irradiation in pregastruía stages. Arch Entwicklungsmech. Crgan. 163: 178-183. (In German) (NSA 24-19351).

:lallace, H., S. Wessels and K. Conn. 1971. Radioresistance of nerves in amphibian limb regeneration. Arch. Entwicklunesmech. Organ. 166, 219-225. (NSA 2532525).

Wilits, D. I. 1974. Radiosensitivity of the roughskinned newt. Department of General Science, Oregon State Univ., Corvallis, Gregon, report RIO.$2227-\mathrm{P} 8-6$. 44 pp. (NiA 32-3746).

Willis, D. I. and W. I. Lappenbusch. 1976. The radiosensitivity of the rough-skinned newt (Taricha Eranulosa). pp. 363-375. Int Radioecology and Enerey Resources. (C. E. Cushing, Jr. et al., eds.). Dowden, Hutchinson and Rose, StroudsburE, PA.

Witcofski, R. I. 1967. The relationship of hypoxia to the effects of $x$-radiation on ribonucleic acid synthesis in the liver of Triturus viridescens. Thesis, Wake Forest College, Winston-Salem, NC. $112 \mathrm{pp}$. (NSA 22-47489).

Wolff, E. and ir. Reyss-irion. 1957. Effect of $x$-rays on gastrula of a batrachian urodele: Pleurodeles waltili. Comyt. Rend. 244(26): 3172-3175. 
Worgul, B. V. 1974. Investigation of raciation cataract by hormonal manipulation of lens Browth. Dissertation, Univ. of Vermont, Burlington. $277 \mathrm{pp.} \mathrm{(Univ.}$ liicrofilms crder No. 74-22,035). (NSA 31-811). (Frog).

Yamada, T. and $\mathrm{M} . \mathrm{Z}$. Roesel. 19C:. Effects of actinomycin $D$ on the lens regenerating system. $J$. Embryol. Expt1. Morphol. 12(4):713-725. (NSA 19-45738). (Triturus).

Yamanoto, [\%. and I. Hotomura. 1968. Biological effect of electron beam irradiation on small creatures. 2. Change in the digestive canal of newts due io 6o-HeV electron beam. Res. Rep. Lab. Nucl. Sci., Tohoku Univ. 1(2): 143-147. (In Japanese) (NSA 24-21279).

Yoshida, Y., S, Kawasaki, K. Takano, T. Ohashi, H. Kusaka, Y. Mikami and S. Ueki. 1957. Induction of situe inversus cordis et viscerum by culturing in radioactive $\mathrm{Ca}$ and $\mathrm{Fe}$ solution. Hile lied. J. 7(2.), 7993. (Toad!. 


\section{Rentiles}

(Turtle)

Daniel, A. P. and B. Highmann. 1951. Some effects of x-irradiation on turtles. J. Exptl. 2001. 118(1): 1-10.

Gaidamakin, N. A., G. P. Parfenov, V. G. Petrukhin and v. V. Antipov, 1971. Results of studies concerning turtles flown on some apace ships. Izv. Akad. Nauk. SSSR (Biol,) 3, 451-453. (In Russian; English summary) (Environmental Poliution Bioresearch Today $1(9), 147$ ). (Concerns ionizing radiation).

Krebs, A. T. 1961. Immediate reaction of the redeared turtle (Peeudemys scriota elecans) to $x$-irradiation. Radiation Res, $15(3): 372-377$. (NSA 152426).

Pezard, A. G. 1958. Effect of maturity and $x$-ray castration on the color centers of the reting in chelonians. Compt. Rend. Soc. Biol. 152, 414-416. (In French) (ISA 12-16878).

Pezard, A. G. 1958. Effect of sexual maturity and of castration induced by $x$-rays on turtles. J. Physiol. (Paris) 50(2): 450-451.

\section{Misceztoneous}

Khomutovsiciy, O. A. 1965. Microscopic and submicroscopic changes in the liver during radiation sickness provoked by radioactive strontium. F1ziol. 2h. , Akad. Nauk Ukr. RSR 11, 208-219. (In Ukralnien) (NSA 1936000). (Porpolses).

Krumholz, I. A. and J. H. Rust. 1954. Osteogenic sarcoma in a muskrat from an area of high environmental radiostrontium. A. M. A. Arch. of Pathol. 57, 270-278.

Olsson, Y., A. I. Caraten and I. Klatzo. 1972. Effects of Eemma radiation on the shark brain. Acta Neuropathol. $21(1), 1-10$, (NSA 26-53487). 


\section{MISCEITANEOUS}

Angelovic, J. W., J. C. White, Jr, and D. W. Engel. 1966. Influence of galinity on the response of estuarine animals to ionizing radiation (abstr.). Bull. Assoc. Southeastern Biol. 13(2): 29.

Bittel, R., R. Kirchmann, G. Van Gelder-Bonnijns and G. Koch. 1974. In situ study of a natural aquatic ecosystem contaminated by tritiated liquid effluents with a view to evaluating the sensitivity of the parameters involved in assessing population exposure levels. pp. 613-621. In: Population Dose Evaluation and Standards for Man and His Environment. Intern. A tomic Energy Agency, Vienna, Austria, publication STI/PUB375. (NSA 31-19592).

Dolgopolskaya, Ni. A., L. A. II'in, I. A. Puzanov and V. A. Tsenev. 1959. Use of radiolsotor is in the control of marine fouling. Atom. Einergiya $6(6), 674-676$. (English transl. pp. 508-510).

Finstad, J., K. Fange and R. A. Good. 1969. The development of lymphoid systems: Immune response and radiation sensitivity in lower vertebrates. Adv. Expti. Med. Biol, 5: 21-31. (Petromyzon marinus, Muxine glutinola, Golfingia procera, Garcinus maenus, crayfish.

Graynum, M. If. 1973. Effects of thermal shock and ionizing radiation on primary prod ctivity. pp. 639-644. In: Fadionuclides in Ecosyg usms. (D. J. Nelson, ed.). U. S. AEC report CONF-710501-PI. (NSA 2537756). (Chlamydomonas reinhardi, Yonochrusis lutheri, mixed phytoplankton species).

Hanawalt, P. C. 1975. Repalr processes in diverse systems. pp. 503-506. In, Molecular Hechnisms for Repair of DNA, Part B. (P. C. Hanawalt; od.). Plenum Press, NY. (Includes UV and $x$-irradiation; Tetrahysns, Micrococcus, Vicis. Nicetinia, Holophopus, chlamydom ONE). (ERA 1-7528).

Havlik, V. No date. Effect of radium on primary production organisms. Institut Hygieny a Epidemiologio, Fraque. (INIs-af-887-2). pp. $77-80$. (In Rusgian) (NSA 30-3577). (INIS ATCUINDEX RN 103689). (Alcae). 
Hortobagyi, T. and J. Vigassy. 1967. Micro-organisms in the reactor circuits exposed to radiation of the nuclear reactor. Budapest-Csillebere. Acta Biol. Hung. 18: 151-160.

Hug, 0.1960 . Reflex-like responses of lower animals and mammalian organs to ionizing radiation. pp. 217224. In: Immediate and Low Level Effects of Ionizing Radiations. (A. A. Buzzati-Traverso, ed.). Intern. J. Radiation Biol. Spec. Suppl. (Snails, clams, actiniae, leech, barnacle, sea urchin).

Il'yin, B. W. 1964. The effect of strontium 89 on the microflora of biological filters. Gigiena i Sanit. 29(2), 102-104. (English trans1. JPRS-23903). (NSA $18-19451$; 18-27732).

Kostromskaya, V. A. 1972. Change in the intensity of oxidative phosphorylation and the activity of catalase during irradiation of various species of invertebrates. Radiobiologiya 12(3): 437-441. (English transl. AEC$\operatorname{tr}-7402$ ). (NSA 27-17675). (Ilanarla, roundworms, tubeworms, earthworms, leeches, mollusks, Daphnia, shrimp, roodlice, cockroach).

Moskalev, Yu. I. and V. N. Streltsova. 1976. Blas tomogenic action of small doses of external sources of radiation and incorporated radionuclides. Inf. Byull. No. 19, Sci. Council on Problems of Radiobiology, Acad. Sci., USSR, Moscow. (In Russian).

Pollkarpov, G. G. 1977. Effects of lonizing radiation upon aquatic organisms (chronic irradiation). pp. 25-46. In: Atti della Giornata sul ma Alcuni Aspettis di Radioecologia. XX Congresso Nationale, Associazione Italiana di Fisica Sanitaria - Protezione Contro le Radiaziont. Bologna.

Polikarpov, G. G. 1979. Bxperimental methods for radiobiological investigations with devaloping fion eggs. pp. 173-194. Ins Methodology for Assessing Impects of Radioactivity on Aquatic Syatems. Intern. Atomic Energy Agency, Vienna, Austria, Tech. Repts. Series No, 190.

Ragsdale, H. I. 1968. The effects of blotic complexity and fast noutron radiation on ceaium-137 and cobalt60 kinetics in aquatic microcosms. Thesis, Univ, of Tennessee, Knoxvilie. (Also: Oak Ridge NatI. Lab.. U. S. AEC report ORNL-4318). (NSA 23-12043). 
Timofeyeva-Resovskaja, Ye. A. 1958. Rate of underwater overgrowth (periphyton formation) in the presence of weak concentration of radioactive substances. Byul1. Ural'sk. Otd. Hoskov. Obshch. Isp. Prirody Akad. Nauk SSSR 1, 87-96. (In Russian).

I'imofeyev-Resovskiy, N. V., N. A. Poryadkova, Ye. N. Sokurova and Ye. A. Timofey eva-Resovskaya. 1957. Effect of radioactive substances on the biomass and structure of earth, soil and freshwater biocenoses. Sbornik. Rabot Lab. Blofiz. Ural'sk. Fil. Akad. Nauk SSSR 1. 202-251. (In Russian).

Vinberg, G. G. and V. I. Gaponenko, 1958. The development of various aqyatic organisms in cultures at various levels of $32 \mathrm{p}$ activity. Tr., Biol. Stants. Oz. Naroch' (1), 193-196.

Williams, R. B. and M. B. Murdocn. 1973. Effects of continuous low-level gamma radiation on sessile marine invertebrates. pp. 551-562. In Radioactive Contamination of the Marine Environment. Intern. Atomic Energy Agency, Vienna, Austria, publication STI/PUB-313. (NSA 28-8487).

Williams, R. B. and M. B. Murdoch. 1973. The effects of continuous low-level gamma radiation on estuarine microcosms. pp. 1213-1221. In: Radionuclides in scosystems. (D. J. Nelson, ed.). U. S. AEC report CONF-710501-P2. (NSA 28-30244). (Phytoplankton, zooplankton, benthos, attached algae).

Zhogova. V. H. 1961. Effects of radioactive strontium on microflora of water and on mineralization processes of organic substances. pp. 314-319. In: Distribution, Biological Effects, and kigration of Radioactive Isotopes. (A. V. Iebedinskiy and Yu. I. Hoskalev, eds.). Medgiz, Hoscow. (English transl. AEC-tr-7512). (NSA 30-7177). 
ECOLCGICAL WODELING IN RADIATION ECOLOGY:

\section{SEIECTED REFERENCES}

by

Vincent Schultz

Department of 200105y

Washington State Univertity

Pullman, Washington

1979 
240 
Aoyama, I. and $Y$. Inoue. 1973. Estimation and evaluation of radioactive contamination through a food web in an aquatic ecosystem (1) - An application of the compartment model to transfer of radioactive substances through a food chain. J. Radiat. Res. 14(4): 375-381.

Aoyama, I. and $Y$. Inoue. 1974. A stochastic study on the concentration process of radioactive substances to aquatic organisms. Health Physics 26(2): 191-198. (NSA 29-20882).

Aoyama, I. and $Y$. Inoue. 1975. Estimation and evaluation of the radioactive contamination through a food web in an aquatic ecosystem (2) - System analysis of the transfer of radionuclides through a food web. $J$. Radiat. Res. 16(2): 132-141.

Aoyama, I.. S. Yoshikawa, Y. Inoue and S. Iwao. 1970. Dynamic concentration process of radioactive substances in aquatic organiems. Tentative approach from stochastic theory. Hoken Butsuri 5, 135-140.

Armstrong, N. E. anc E. F. Gloyna. 1969. Mathemetical models for the dispersion of radionuclides in aquatic systems. pp. 329-335. In. Symposium on Radioecology. (D. J. Nelson and F. C. Evans, eds.). U. S. AEC report CONF-670503.

Arnold. J. R. 1958. Trace elements and transport rates in the ocean. Proc. 2nd UN Intern. Conf. on the Peacerul Uses of Atomic Energy $18,344-346$.

Beetle, T. N. 1972. A statistical study of radiation dosage for fishermen. Battelle Northwest. U. S. AEC report BNiL-SA-4449. (i), 9 pp. plus 10 figures.

Belyaev, B. I. 1972. Exchange equations of radionuclides betweer marine organisms and the environment. pp. 6271. In: Radiation and Chemical Ecology of Aquatic Organisms. (G. G. Polikarpov, ed.). "Naukova Dumka," Kiev. (NSA 26-53532).

Bernhard, M. 1972. Utilization of simple models in radioecology. pp. 129-163. In: Warine Radioecology. Organization for Economic Co-operation and Development, Paris. (NSA 29-410). 
Bernhard, M., A. Bruschi and F. lioller, 1975. Use of compartmental models in radioecological laboratory ctudies. pp. 241-289. In: Design of Radiotracer Experiments in Mlarine Biological Systems. I International Atomic Enerey Agency, Vienna, Austria, Tech. Repts. Series No. 167.

Bernard, S. R., I. R. Shenton and V. R. R. Uppuluri. 1967. Stochastic models for the distribution of radioactive materials in a connected system of compartments. Proc. 5th Berkeley Symp. on lathematical Statistics and Probability 4, 481-510.

Bittel, R. 1971. Contribution of a prediction nodel to the establishment of formulae for the discharge of radioactive effluent into water. pp. 977-987. In: Proc. Intern. Symp. Radioecology Applied to the Protection of lian and His Enviroment. Comission of the European Communities, Iuxemburg, report EUR$4800 \mathrm{~d}-f-i-e$. (In French) (NSA 27-5281).

Bittel, R. and G. Lacourly. 1972. Hethod of approach for the evaluation of chemical pollution levels in marine environments and marine food chains. pp. 349-353. In, Marine Pollution and Sea Life. (M. Ruivo, ed.). Fishing News Itd., Iondon. (In French with English abstract).

Bloom, S. G. and G. E. Raines. 1967. A note on the origin of exponential functions in models to describe the transfer of radionuclides through an ecosystern. Battelle isemorial Institute, U. S. AEC report IOCS Memorandum BhI-9 (BhI-860.02). $10 \mathrm{pp}$.

Bloom, S. G. and G. E. Raines. 1969. A preliminary mathematical model for predicting the transport of radionuclides in the marine environment. Bettelle Memorial Institute, U. S. AEC report BMI-171-123. (v). $16 \mathrm{pp}$. plus appendix.

Bloom, S. G. and G. E. Raines. 1971. Mathematical models predicting the transport of radionuclides. In a marine environment. Bioscience 21(12): 691-696.

Bloom, S. G., A. A. Ievin, W. E. Martin and G. E. Raines, 1970. Wathematical methods for evaluating the transport and accumulation of radionuclides. Battelle Nemorial Institute, U. S. AEC report IOCS Memorandum BNI-35 (BiII-860.09). (1), $40 \mathrm{pp}$. 
Bloom, S. G., J. E. Howes, R. A. Ewing and G. E. Raines. 1975. Pretest estimates of hypothetical internal radiation doses from Cannikin via marine food chains. Battelle Columbus Labs.. U. S. ERDA report BMI-171143. $37 \mathrm{pp}$. (NSA 32-14593).

Booth, R. S. 1976. A systems analysis model for calculating radionuclide transport between receiving waters and bottom sediments. pp. 133-158. In, Environmental Toxicity of Aquatic Radionuclides: Models and hechanisms. (M. W. Hiller and J. N. Stannard, eds.). Ann Arbor Sci. Publishers, Ann Arbor, MI. (ERA 2-18271). (ORNL-TH-475I).

Booth, R. S. and S. V. Kaye. 1971. A preliminary gystems analysis model of radioactivity transfer to man from deposition in a terrestrial environment. Oak Ridge National Lab., U. S. AEC report ORNL-TH-3135. 17 pp.

Booth, R. S., S. V. Kaye and P. S. Rohwer. 1973. A systems analysis methodology for predicting dose to man from a radioactively contaminated terrestrial environment. pp. 877-893. Int Radionuclides in Ecosystems. (D. J. Nelson, ed.), U.S. AEC report CONF-710501-P2.

Bowen, V. T., J. S. Olsen, C. I. Osterberg and J. Ravera. 1971. Chp. 8. Ecological interactions of marine radioactivity. pp. 200-222. In R Rioactivity in the Marine Environment. (National Research Council). National Academy of Sciences, Washington, DC.

Branca, G., F. Breuer, A. A. Cigna and R. Amavis. 1971. Application of a mathematical model for determining at $r$ ommunity scale the discharge standards for radioactive effluent. pp. 839-866. Int Proc. Intern. Symp. Radioecology Applied to the Frotection of lian and His Environment. Commission of the European Communities, Luxemburg, report EUR-4800 d-f-i-e. (In Italian) (NSA 27-5263).

Carlssgn. S. 1978. A model for the movenent and loss of $137 \mathrm{Cs}$ in a small watershed. Health Phys. 34(1): 33-37.

Carlason, s. 1978. A model for the turnover of $137 \mathrm{Cs}$ and potassium in pike (Esox lucius): Health Phys. 35(4). 549-554.

Conover, R. J. and V. Franc1s. 1973. The use of radioactive 1sotopes to measure the transfer of materials in aquatic food chains. Marine Biol. 18(4), 272-283. 
Craig, H. 1957. Disposal of radioactive wastes in the ocean: The fission product spectrum in the sea as a function of time and mixing characteristics. pp. 3442. In, The Effects of Atomic Radiation on Oceanography and Fisheries. National Academy of SciencesNational Research Council, Washington, DC.. publication 551.

Crossley, D. A., Jr. and D. E. Relchle. 1969. Analysis of transient behavior of radioisotopes in insect food chains. Bioscience 19(4):341-343.

Crossley, D. A., Jr, and C. S. Gist. 1973. Use of radioisotopes in modeling soil microcommunities. pp. 258 278. In: Proc. First Soll hicrocomunities Conference. (D. L. Dindal, ed.). U. S. AEC report CONF-711076.

DiGregorio, D., T. Kitchings and P. Van Voris. 1978. Radionuclide transfer in terrestrial animals. Health Physics 34(1), 3-31.

Eberhardt, I. I. 2969. Similarity, allometry, and food chains. J. Theoret, Biol. 24(i), 43-55.

Eberhardt, I, I. 1973. Hodeling radionuclides and pesticides in food chains. pp. 894-897. In: Radionuclides in Ecosystems. (D. J. Nelson, ed.). U.S. AEC report CONF-710501-P2.

Eberhardt, L. I. 1975. Some methodology for appraising contaminants in aquatic systems. J. Fish. Res. Bd. Can. 32(10): 1852-1859. (ERA 2-44150).

Eberhardt, I. I. 1978. Designing ecological studies of trace substances. pp. 8-33. In: Environmental Chemistry and Cycling Processes. (D. C. Adriano and I. I. Brisbin, Jr., dz.). U.S. DOE report CONF-760429. (DOE Symp. Series 45$\}$ :

Eberhardt, I. L. and R. E. Nakatani. 1968. A postulated effect of growth on retention time of metabolites. J. Fish. Res. Bd. Can. 25(3), 591-596.

Eberhardt, I. L. and W. C. Hanson. 1969. A simulation model for an arctic food chain. Health Phys. 17(6): 793-806. 
Eberhardt, I. I. and R. E. Nakatan1. 1969. Modeling the behavior of radionuclides in some natural systems. pp. 740-750. In: Symposium on Radioecology. (D. J. Nelson and F. C. Evans, eds.). U. S. AEC report CONF-670503.

Eberhardt, L. L. and R. O. Gilbert. 1973. Gamma and lognormal distributions as models in studying foodchain kinetics. Battelle Northwest, U. S. ERDA report BNWL-1747. iii, $95 \mathrm{pp}$.

Eberhardt, I. I., R. O. Gilbert, H. I. Hollister and J. M. Thomas. 1976. Sampling for contaminants in ecological systems. Environmental Science and Technology 10(9), 917-925.

Elwood, J. W. and I. D. Eyman. 1976. Test of a model for predicting the body burden of trace contaminants in aquatic consumers, J, Fish. Res. Bd. Can. 33(5): 1162-1166. (ERA 2-14812).

Espey, W. H., Jr., E. F. Gloyna and R. D. Talor. 1978. Appendix. Hydrologic tranapcrt of radionuclides. pp. 55-72. In: Proc. of a Warkshop on the Evaluation of Models Used for the Enviror.mental Assessment of Radionuclide Releases. (Vario is authors). U. S. DOE report CONF-770901.

Fagerstrom, T. and B. Asell. 1976. Caged fish for estimating concentrations of trace substanies in natural waters. Health Fhys. 3I(5): 431-439.

Federov, A. F. 2964. Fiathomatical frmulas for concentration coefficient study of radioactive material to sea biota. Bull. Inst. Dceanogr. $63(1304)$, 11 pp.

Feldt, W. 1974. Nuclear explosions an: marine radiobiology. pp. 77-94. In: Kontamination und Dekontamination von Lebensmitteln. ( $\mathrm{E}$. Fischer, oG.). AID, Bonn. (CONF-700685). (In German) (NSA 3:-17204).

Freke, A. M. 1967. A model for the appzoximate calculation of safe rates of discharge of radoa:tive wastes into marine environments. Health Fhys. $1 ;(7)$, 743-758. (NSA 21-32353). 
Frittelli, I. 1974. Application of systens analysis methodology to the determination of the limiting radiological capacity of the area surrounding a nuclear facility. pp. 425-432. In: Environmental Surveillance Around Nuclear Insiallations. Volume 1. International Atomic Energy Agency, Vienna, Austria, publication STI/PUB-353. (NSA 31-14081).

Garten, C. T., Jr., R. H. Gardner and R. C. Dahlman. 1979. A compartment model of plutonium dynamics in a deciduous forest ecosystem. Health Phys. 34(6), 611-619.

Gist, C. S. and F. W. Whicker. 1971. Radioiodine uptake and retention by the mule deer thyroid. J. Wildl. Mgnt. 35(3), 461-468.

Gist, C. S., K. M. Duke and B. C. Patten. 1973. A systems analysis of a model for radioiodine movement in mule deer. pp. 909-914, In: Radionuclides in Ecosystems. (D. J. Nelson, ed.). J. S. AEC report CONF.710501-P2 .

Gloyna, E. F, and J. O. Ledbetter. 1969. Chp, 10, Environmental transport of radionuclides. pp. $2 i 3-284$. Iil: Principles of Radiological Health. (E. N. Gloyna and J. o. Iedbetter). Marcel Dekker, $N Y$.

Gloyna, E. F. et ai. 1978. Hydrologic transport of radionuclides. pp. 33-54. In: Proc. of a Workshop on the Evaluation of kodels Used for the Environmental Assessment of Radionuclise Releases. (Various authors). U. S. DOE report CONF-77090I.

Goldstein, R. A. and J. W. Elwood. 1971. A two-compartment, three-parameter model for the absorntion and retention of ingested elements by animals. Ecology $52(5): 935-939$.

Gus 'kova, V. N., O. N. Prokof'yev, A. A. Zasedatelev, B. N. II' in and A. I. Tikhonova. 1971. Dynamics of concentration of strontium-89 in water and carp tissues after a single contamination of a body of water. Hydrobiol. J. 7(1): 53-56. (English trans.).

Halfon, E. and R. E. Bargmann, 1976. System identification of radioisotope flows in aquatic microcosms. pp. 184193. In: Radioecology and Enerey Resources. (C. E. Cushing. Jr. et al.. eds.). Dowden, Hutchinson and ROBs, StroudsburE, PA. 
Hanson, W. C. and I. I. Eberhardt. 1969. Effective half-times of radionuclides in Alaskan lichen and eskimos. pp. 627-634. In: Symposium on Radioecology. (D. J. Nelson and F. C. Evans, eds.). U. S. AEC report CONF-670503.

Hawthorne, H. A., S. D. 2ellmer, I. I. Eberhardt and J. M. Thomas. 1976. 137Cesium cycling in a Utah dairy farm. Health Phys. 30(6), 447-464.

Hess, C. T. and C. W. Smith. 1977. A mathematical model of the accumulation of radionuclides by oysters (c. virginica) aquacultured in the effluent of a nuclear power reactor to include major biological parameters. Health Fhys. $33(2)$ : 12l-130.

Hoffman, F. H. 1978. Concluding remarks. pp. 123-126. In: Proc. of a Workshop on the Evaluation of Models Used for the Environmental Assesament of Radionuclide Releases. (Various authors). U. S. DOE report CONF770901 .

Hoffmen, G. R. 1972. The accumulation of cesium-137 by cryptogams in a Iirfodendron tulipifera forest. Bot. Gaz. $133(2): 107-119$.

Horfman, F. O., C. W. Miller, D. L. Shaeffer and C. T. Garten, Jr. 1977. Computer codes for the assessment of radionuclides released to the environment. Nuclear Safety 18(3): 343-354.

Hoffman, F, O., C. W. Miller, D. L. Shaeffer, C. T. Garten, Jr., R. W. Shor and J. T. Ensminger. 1977, A compilation of documented computer codes applicable to environmental assessment of radioactivity releases. Oak Ridge National Lab., U. S. ERDA report ORNI/TM-5830. xili, $70 \mathrm{pp}$.

Isaacs, J. D. 1973. Potential trophic biomasses and tracesubstance concentrations in unstructured marine food webs. Marine Biol, 22(2), 97-104.

Ivanov, V. N. and D. S. Parchevekaya. 1974. The probable character of accumulation and effect of radionuclides in the marine environment. Dokl. Akad. Nauk SSSR 218(1): 215-218. (English transi.. pp. 428-430). (NS:A 31-25770). 
Kahn, B. 1976. Measurements for modeling radionuclide transfer in the aquatic environment. pp. 165-181. In! Environmental Toxicity of Aquatic Radionuclides, Models and liechanisms. (vi. W. Miller and J. N. Stannard, eds.). Ann Arbor Science Fublishers, Ann Arbor, MI. (ERA 2-18272).

Kaye, S. V. and D. J. Nelson. 1968. Analysis of specificactivity concept as related to environmental concentration of radionuclides. Nuclear Safety $q(1)$, 53-58.

Kaye, S. V. and P. S. Rohwer. 1969. Predicting radiation dose equivalents for populations. II. Results obtained with the dose models. Bioscience 19(2): 326-330.

Kaye, S. V. and S. J. Ball. 1969. Systems analysis of a coupled compertment model for radionuclide transfer in a tropical environment. $\mathrm{pp}$. 731-739. In: Symposium on Radioecology. (D. J. Nelson and F. C. Evans, eds.). U. S. AEC report CONF-670503.

Kaye, S. V., P. S. Rohwer, K. E. Cowser and W. S. Snyder. 1969. Predicting radiation dose equivalents for populations. I. Dose models and methods of application. Bioscience $19(3), 238-241$.

Kaye, S. V., R. S. Booth, P. S. Rohwer and E. G. Struxness, 1971. A cumulative exposure index (CUEX) for assessing environmental releases of radioactivity. pp. 909-938. In! Proc. Intern. Symp. Radioecology Applied to the Protection of Iian and His Environment. Commission of the European Communities, Iuxemburg, report EUR-4800 d-I-1-e. (NSA 27-5239).

Killough, G. G. and I. R. HcKay (comps.). 1976. A methodology for calculating radiation doses from radioactivity released to the environment. Oak Ridge National Lab., U. S. ERDA report ORNL-4992. xiv, various pages.

Kulikov, N. V., V. S. Bezel and I. N. Ozhegov. 1970. Accumulation of radiolsotopes by developing roe of tench (Iinca tinca $L_{.}$) and perch (Perca Iluviatilis L.). Ekologiya $1(5): 73-77$. (EnElish trans1. pp. 425-428).

Lerman, A. 1973. Transport of radionuclides in sediments. pp. 936-944, In: Radfonuclides in Ecosystens. (D. J. Nelson, ed.). U. S. AEC report CONF-701501-P2. 
Iu, A. H. 1978. Nodeling of radionuclide migration from a low-level radioactive waste burial site. Health Phys. 34(1): 39-44.

Martin, W. E. and F. B. Turner. 1966. Transfer if $89 \mathrm{Sr}$ from plants to rabbits in a fallout field. Health Phys. $12(5)$ : $621-631$.

liartin, W. E. and G. E. Raines. 1969. Ecological transfer mechanisms--terrestrial. pp. 401-433. In: Proc. for the Symposium on Futilc Health Aspects of Peaceful Uses of Nuclear Explosives. U. S. Fublic Health Service report SilRHL-B2.

Martin, W. E., G. E. Raines, S. G. Bloom, A. A. Levin and J. A. Duke. 1971. hiathematical models of radionuclide transport in ecosystems. pp. 39-99. In: Nuclear Cratering Explosion Effects for Interoceanic Canal Feasibility Studies. (A. W. Klement, Jr., ed.). J. S. AEC report NVO-6? (Rev, 1).

Miller, C. W., D. E. Dunning, Jr., E. I. Etnier, F. 0. Hoffman, C. A. little, H. R. Heyer, D. I. Shaeffer and J. E. Till. 1979. The evaluation of selected predictive models and parameters for the environmental transport and dosimetry of radionuclides. Oak Ridge National Lab. . U. S. DOE report ORNL/TM-6663, $x, 87$ pp.

Murray, C. N. and A. Avogadro. 1979. Effect of a lonE-term release of plutonium and americium into an estuarinecoastal sea ecosystem. I. Development of an assessment methodology. Health Fhys. 36(5): 573-585.

Neel, R. B. and J. S. Olson. 1962. Use of analog computers for simulating the movement of isotopes in ecological systems. Oak Ridge National Lab., U. S. AEC report ORNL-3172. xil, $108 \mathrm{pp}$ (Also, R. B. Neel, Thesis, Vanderbilt Univ., Nashvilie, TN.).

Olson, J.S. 1963. Analog computer models for movement of nuclides through ecosystems. pp. 121-125. In: Radioecology. ( $V$. Schultz and A. W. Klement, Jr., eds.). Reinhold Publishing Corp., NY.

Olson, J.S. 1965. Equations for cesium transfer in a Liriodendron forest. Health Physics $11(12), 1385-1392$.

O'Neill, R. V. 1970. Fathway analysis, a preliminary application of systems ecology to nuclear facility safety evaluation. Cak. Ridee National Lab., U. S. AEC report CRNL Central Files No. 70-3-24, 23 pp. (Internal use only). 
O'Nelll, R. V. 1973. Error analysis of ecological models. pp. 898-908. InI Radionuclides In Ecosystems. (D. J. fielson, ed.). U. S. AEC report CONF-710501-PI.

Onishi, Y. 1977. Finite element models for sediment and contaminant transport in surface waters. Transport of sediments and radionuclides in the Clinch River. Battelle Northwest, U. S. ERDA report BNWL-2227. xiv, 103 pp. plus references.

Onishi, $Y$. 1977. Mathematical simulation of sediment and radionuclide transport in the Columbia River. Battelle Northwest, U. S. ERDA report BNWL-2228. xiv, $89 \mathrm{pp}$. plus references.

Onishi, Y., P. A. Johanson, R. G. Baca and E. L. Hilty. 1976. Studies of Columbia River water quality: Development of mathematical models for sediment and radionuclide transport analysis. Battelle Northwest, U. S. ERDA report BNwL-B-452, iv, $42 \mathrm{pp}$.

Ophel, I. I. et al. 1978. Aquatic food chain transport of radionuclides. pp. 73-84. In: Proc. of a Workshop on the Evaluation of Models Used for the Environmental Assessment of Radionuclide Releases. (Yarious authors). U. S. DOE report CONF-770901.

Parchevskaya, D. S. 1970. Scheme of statistical analysis and planning of experiment. pp. 26-28. In: liarine Radioecology. (G. G. Polikarpov, ed.). Kiev, Fublishing House Acad. Sci. Ukr. SSR. (English transl., AEC-tr7299).

Parzyck, D. C., J. P. Witherspoon and J. E. Till. 1976. Validation of environmental transport models in the CUEX methodology. pp. 194-198. In Radioecology and Energy Resources. (C. E. Cushing. Jr. et al., eds.). Dowden, Hutchinson \& Ross, Stroudsburg, $\bar{P}_{A}$.

Patten, B, C. 1964. The systems approach in radiation ecology. Oak Ridge National Iab., U. S. AEC report ORNL-Tin-1008. 19 pp.

Patteq B. C, and M. Witkamp. 1967. Systems analysis of 134 cesium kinetics in terrestrial microcosms. Ecology $48(5): 813-924$. 
Patzer, R. G. 1976. Concentration factors and transport models for radionuclides in aquatic environments. A literature report. Final report. Environmental Monitoring and Support Lab., U. S. EPA, Las Vegas, NV., report $\mathrm{PB}-255097$. $64 \mathrm{pp}$. (ERA 2-38387).

Piskunov, I. I. 1970. Statistical study of the accumulation of radioisotopes in aquatic organisms. Gidrobiol. Zh. 6(5): 70-72. (English transl. Hydrobiol. J. 6(5): $58-60)$.

Piskunov, I. I. 1971. Quantitative aspects of the accumulation of radioisotopes by freshwater organisms. Gidrobiol. 2h. 7(1): 64-68. (English transl. Hydrobiol. J. $7(1)$ : 49-52). (NSA 26-9494).

Piskunov, I. I. and G. I. Voznesenskaya. 1976. A parameter of radionuclide accumulation in freshwater plants. DokI. Akad. Nauk SSSR 230(3): 741-744. (English trans1., pp. 423-426).

Preston, A. 1972. Critical path analysis applied to the control of radioactive waste disposal to aquatic environments. pp. 121-134. Ins Disposal of Radioactive Waste. Nuclear Energy Agency, Organization for Economic Co-operation and Development, Faris.

Preston, A. 1974. Application of critical path analysis techniques to the assessment of environmental capacity and the control of environmental waste disposal. pp. 573-583. In: Comparative Studies of Food and Environmental Contamination. International Atomic Enerey Agency, Vienna, Austria, publication STI/PUB/348. (NSA 30-15540).

Prokhorov, V. M. No date. Mathematical modelling of radionuclide migration in certain regions of biosphere. (INIS-mg-887). pp. 252-265. (In Russian) (NSA 2915629).

Prokhorov, V. M. and I. R. Ginzburg. 1971. Modelling the process of migration of radionuclides in forest ecogystems and description of the model. Ekologiya $2(5)$, 11-19. (Englieh transl. Sov. J. Ecol. 2(5), 396-402).

Prokhorov, V. M, and N. G. Safronova: 1973, Kinetics of the self-purification of a body of water containing strontium-90 as a result of absorption of the radiomuclide by the botton doposits. Ekologiya $4(2), 12-18$. (English transl. Sov. J., Ecol. 4(2), 101-105). 
Prokhorov, V. M., M. V. Ryzhinskiy and A. M. Margolin. 1973. Numerlcal method of calculating the dynamics of sorption of a substance in a medium with variable transfer coefficients. Radiokhimiya 15(3): 298-304. (English transl. Sov. Radiochem. 15(3): 302-306). (ISA 30-6527).

Raines, G. E., S. G. Bloom and A. A. Levin. 1969. Ecological models applied to radionuclide transfer in tropical ecosystems. Bioscience 19(12): 1086-1091.

Reichle, D. E. 1967. Radioisotope turnover and energy flow in terrestrial isopod populations. Ecology $48(3)$ : $351-366$.

Reichle, D. E. 1969. Measurement of elemental assimilation by animals from radioisotope retention patterns. Ecology $50(6): 1102-1104$.

Reichle, D. E., P. B. Dunaway and D. J. NelBon. 1970. Turnover and concentration of radionuclides in food chains. Nuclear Safety II(1), 43-55. (NSA 24-12038).

Rodionova, I. F. and S. Ya, Sukal'skaya. 1969. The accumulation of $\mathrm{Ba}-140$ and $\mathrm{Ia}_{\mathrm{a}}-140$ by planktonic organisms from fresh water. Gidrobiol. 2h. 5(6). (English transl. Hydrobiol. J. 5(6):70-74).

Ruzic, I. 1972. Two-compertment model of radionuclide accumulation into marine organisms. I. Accumulation from a medium of constant activity. Marine Biol. 15(2): 105-112.

Sama, T. P., T. M. Kriehnamoorthy and V. N. Sastry, 1971. An approach to the calculation of the allowable specific activities in marine fishes. Health Fhys. 20(1): 23-30.

Schreckhise, R. G. and F. H. Whicker. 1976. A model for predicting strontium-90 levels in mule deer. pp. 148156. In: Radioecology and Energy Resources. ?C. B. Cushing, Jr., et al., eds.). Dowden, Hutchinson Ross, Stroudsburg, PA.

Shih, C. S. and E. F. Gloyma. 1970. Hathematical model for the transport of radionuclides in stream system. pp. 320-341. In Environmental Surveillance in the Vicinity of Nuclear Facilities. (W. C. Reinig, ed.). Charles C Thomas, Springfield, IL. 
Soldat, J. K., D. A. Baker and J. P. Corley: 1973. Applications of a general computational model for composite environmental radiation doses. pp. 483-498. In: Environmental Behaviour of Radionuclides Released in the Nuclear Industry. Intern. Atomic Energy Agency, Vienna, Austria, publication STI/PUB/345.

Soldat, J. K., N. M. Robins on and D. A. Baker. 1974. Niodels and computer codes for evaluating environmental radiation doses. Battelle Northwest, U, $S$. AEC report BNiL-1754. iv, various number pages.

Soldat, J. K. et al. 1978. Terrestrial food chain transport of radionuclides. pp. 85-98. In Proc. of a Horkshop on the Evaluation of Hodels Used for the Environmental Assessment of Radionuclide Releases. (Various authors). U. S. DOE report CONF-770901.

Svirezher, Yu. M., V. I. Anokhin and A. M. Tyuryukanov. 1971. Quantitative models in radiation biocoenology. pp. 207-215. In: Viethods of Radioecological Investigations. (I. N. Verkhovskayay, ed.). Atomizdat, Noscow. (In Russian) (NSA 26-12255).

Turner, F. B. 1965. Uptake of fallout radionuclides by mammals and a stochastic simulation of the process. pp. 800-820. In: Radioactive Fallout from Nuclear Weapons Tests. (A. W. Klement, Jr., ed.). U. S. AEC Symposium Series No. 5.

Turner, F. B. and R. I. Jennrich. 1967. The concentration of $131 \mathrm{I}$. in the thyroids of $h$ rrbivores and a theoretical consideration of the expected frequency distribution of thyroidal $13 I_{I}$ in a large consumer population. pp. 175-182. In: Radioecological Concentration Processes. (B. Aberg and F. P. Hungate, eds.). Pergamon Fress, NY.

Vanderploeg, H. A. and R. S. Booth. 1976. Interpretation of biological-rate coefficients derived from radionuclide content, radionuclide concentration and specific activity experiments. Health Phys. 31(1): 57-59.

Vanderploeg, H. A., R. S. Booth and F. H. Clark. 1976. A specific activity and concentration model applied to cesium-137 novement in a eutrophic lake. pp. 164-177. In: Radioecology and Bnergy Resources. (C. E. Cushing, Jr. et al.. eds.). Dowden, Hutchinson \& Ross, Strouds burg, FA. 
Van Dyne, G. M. 1964. Application of some operations research techniques to food chain analysis problems. Health Fhys. 11(12): $1511-1519$.

Van Winkle, W. 1977. Modeling techniques for predicting long-term consequences of the effects of radiation on natural aquatic populations and ecosystems. Cak Ridge Natl. Iab., U. S. DOE report CONF-771115-2. 12 pp. (ERA 3-19807).

Various authors. 1978. Proceedings of a Workshop on the Evaluation of hodels Used for the Environmental Assessment of Radionuclide Releases. U. S. DOE report CONF-770901. iii, 131 pp.

Vaughan, B, E. and J. A. Strand. 7870. Biological implications of a marine release of $90 \mathrm{Sr}$. Health Phys. 18(1): 25-41. (NSA 24-12039).

Watts, J. R. 1976. Modeling of radiation doses from chronic aqueous releases. Du Pont de Nemours, U. S. ERDA report DP-lis-75-126. 14 pp. (CONF-760652-1). (ERA $1-24582)$.

Watts, J, R. and C. E. Jurphy, Jr. 1978. Assessment of potential radiation dose to man from an acute tritium release into a forest ecosystem. Health Phys. 35(2): 287-291.

Webb, G. A. H. and F. Horley. 1973. Model for the evaluation of the deep ocean disposal of radioactive waste. National Radiological Protection Board, Harwell, England, report NRPB-R-14. 29 Pp. (NS̈A 28-22128).

Webb, G. A. M, and F, Norley, 1974. Hodel for the evaluation of the deep ocean disposal of radioactive waste. pp. 313-318. In! Proc. Third Intern. Congr. Intern. Radiation Protection Assoc. (CONF-730907-Pl). (NSA 30-26768).

White, G. C., I. W. Adams and T. A. Bookhout. 1978. Simulation model of tritium kinetics in a freshwater marsh. Health Phys, 34 (1), 45-54.

Wiggins, A. D. 1960. On a multicompartment migration model with chronic feeding. Biometrics 16(4), 642658 . 
Yegorov, V. N. and I. G. Kulebakina, 1973. Mathematical model of 5 r90 exchange between Cystoseira and marine water. pp. 281-285. In Radioecology of Water Organisms. II. Distribution and Vigration of Radionuclides in Freshwater and Seawater Biocenoses. (G. P. Andrushaitis, ed.). "Zinatne," Riga. (English transi. AEC-tr-7606; pp. i67-169). (NSA 30-21148).

Yegorov, V. N. and G. G. Polikarpov, 1974. Nathematical applications of radioecological investigations under expedition conditions. pp. 5-30. In: Chemoradioecology of Pelagic and Benthic 2ones (Metals and Radionuclides in Aquatic Organisms and Environment). (G. G. Folikarpov, ed.). "Naukova Dumka," Kiev. (NSA 30-29422).

Yegorov, V. N. and I. G. Kulebakina. 1974. Niathematical model of exchange of $5 r 90$ between Cystoseira and marine water. pp. 30-39. In, Chemoradioecology of Pelagic and Benthic Zones (hietals and Radionuclides in Aquatic Organisms and Environment). (G. G. Polikarpov, ed.). "Naukova Dumka," Kiev. (NSA 30-29422).

Yousef, Y. A. and E. F. Gloyna. 1975. Transport model for long term radionuclide release into a stream ecosysten. Am. Chem. Soc. Div. Environ. Chem. Prepr. 15(1): 148151. (ERA 2-30B85).

2uccaro Labellarte, G. 1974. A distribution model for radioactive and other persistent pollutants in the enviroment and in the food chain. pp. 585-593. In: Comparative Studies of Food and Environmental Contamination. Interna. Atomic Enerey Agency, Vienna, Austria. STI/PUB $/ 348$.

\section{Hiscellaneous References}

Goldberg, E. D., I. N. IicCave, J. J. O'Brien and J. H. Steele (eds.). 1977. Marine thodeling. The Sea, vol. 6. Wiley-Interscience, NY. xiv, $1048 \mathrm{pp}$.

Harrison, E. A. 1975. Ecosystem models (a bibliography with abstracts). Report for 1964-0ctober 1974. National Technical Information service, Springfield, Virginia, report NTIS/FS-75/088. 149 pp. (NSA 33-643). 
Harrison. E. A. 1975. Ecosystems models (a bibliography with abstracts). Report for 1964-November 1975.

National Technical Information Service, Springfield, virginia, report NTIS/PS-75/846, 219 pp. (ERA 211192).

Harrison, E. A. 1976. Ecosystem models. Vol. 1. 1964October 1975 (a bibliography with abstracts). Report for 1964-November 1975. $219 \mathrm{pp}$.; Vol. 2 . November 1975-November 1976 (a bibliography with abstracts). Report for November 1975-November 1976. $81 \mathrm{pp}$. National Technical Information Service, Springfield, VA., reports NTIS/PS $-76 / 0903$ and 0904, resp. (ERA 2-38355; 38356$)$.

Haven, K. F. 1975. Methodology for 1mpact assessment in the estuarine/marine environment. Univ. of California, Lawrence Iivermore Iab., report UCRI-51949. $45 \mathrm{pp}$. (NSA 33-20238).

Izrael, Yu. A. 1976, An evaluation of the state of the biosphere and a basis for monitoring. Dokl. Akad. Nauk SSSR 226(4), 955-957. (English transl. pp. 11-12).

Izrael, Yu. A.. I. M. Filippova, F. N. Semevskiy, S. M. Semenov and G. E. Insarov. 1978. Principles of ecological monitoring under conditions of residual pollution of an environmental ecosystem. Dokl. Akad. Nauk SSSR (biol. sci.) 24I(1), 253-255. (English transl. pp. 323-325).

Izrael, Yu. A., I. M. Nazarov, I. IT. Filippova, Yu. A. Anokhin, V. M. Koropalov, A. Kh. Ostromogil'skiy and A. G. Ryaboshapko. 197B. Ecological approach to the assessment of the state of the ecosystem and to control its quality. Dokl. Akad. Nauk SSSR (biol. sci.) 241(3), 723-726. (English trans1. pp. 325-329).

Nihoul, J. C. J. (ed.). 1975. Modelling of Harine Systers. Elsevier Scientific Pubilishing Co., NY. $x i x, 272 \mathrm{pp}$.

0'Neil, R. Y., N. Gergus on and J. A. Watts. 1977. Bibliography of mathematical modeling in ecology. Oak Ridge National Iab. report EDFB/IaP-75/5. \&i pp. (ERA 3-31810).

Owen, P. T., N. S. Dalley, C. A. Johnson and F. M. Niartín. 1979. An inventory of environmental impact models related to energy technologies. Oak Ridge National Inb., U. S. DOE report ORNI/EIS-147. vi1, $428 \mathrm{pp}$. 
Weyland, J. R., I. H. Baker, J. T. Ivy and C. A. Bedinger, Jr. 1975. Heavy metals in estuarine benthic organisins and sediments: Data and model. Sandia Iabs.. Albuquerque, Nii., report SAND-75-5869. 32 pp. (ERA 1-7366). 


\title{
AQUATIC RADIATION ECOLOGY: \\ SELECTED REFERENCES ON DOSE AND DOSTMETRY
}

by

\author{
Vincent Schultz \\ Department of zoology \\ Washington State University \\ Pullman, Washington 99164
}

1979 
Abdullah, H. 1973. Ground trail probe for the measurement of gamma density on ocean beds, Nieerestechnik 4(3): 87-89. (In German) (INSA 28-18377).

Acree, H. H., H. R. Brashear, Jr. and F. N. Case. 1972. Device for inserting tafeed sand into ocean floor. U. S. Patent 3,697,756. (NSA 27-17289).

Adams, iN. 1968. Dose-rate distribution from spherical and spherical-shell radiation sources, with special reference to fish eggs in radioactive media. United Viardom Atomic Energy Authority, Harwell, report AHSE (NP)R-8?. $19 \mathrm{pp}$. (NSA 23-24606).

Akiyama, T. 1965. On an instrument for in situ measurement of Eamma-ray activity in deep water of the ocean. Oceanofr. Haet. 17:69-75.

Amano, Y. 1955. Radiation dosinetry of fish. Shizen ('sci. Mafaz. "Shizen") 10(3):43.

jlaylock, B. G. anc J. P. Wi therspoon. 1975. Dose estimation and prediction of radiation effects on aquatic biota resulting from radioactive releases from the nuclear fucl cycle. pp. 377-392. In: Impacts of Wuclear peleases into the Aquatic environment. Intern. A tomic Inerry Aeency, Vienna, Austria, publication STI, SUD/406. (NSA 32-24338).

Fedorov, A. F. 1965. Tradiation doses for some types of marine bioti under present-day conditions. Radioact. Sea (ironace) (14): 1-28. (INAA 20-38741).

solsom, f. R. 1959. Comparison of radioactive dosace from potassium with estimated dosages from uranium and radium in marine biosphere. Froc. Ninth Pacific Science Coneress 16: 176-178.

rolsom, $\because$. R. and J. H. Harley. 1957. Comparison of some natural radiations received by selected organisms. pp. 28-33. In: The Effects of Atomic Radiation on Cceanography and Fisheries. National Academy of Sciences - National Research Council, Washington DC., publication 551 . 
Farchevskaya, D. S. 1969. Estimation of absorbed doses of $\gamma$-radiation in spherical hydrobionts of small sizes. Radiobiologlya 9(2): 28I-285. (English transl. AEC-tr-7025).

Iarchevskaya, D. S. 1970. Estimation of absorbed doses of beta-radiation in spherical hydrobionts of small size, pp. 135-141. In: Viarine Radioecology. (G. G. Folikarpov, ed.). Kiev, Publishing liouse Acad. Sci. Ul:r. SSE. (English trans1. AEC-tr-7299).

lodymakhin, V. N. 1971. Natural radiation loads on the egge of marine and fresh water organisms. Tr. Polyar. Nauch.-Issled. Froekt. Inst. Horsk. Ryb. Yhoz. Okeanogr. (29): 116-127. (English transl. AEC-tr-7418). (NSA 27-28005).

kodymakhin, V. N. 1971. Radiometric and dosimetric characteristics of experiments for detexmining the influence of radioactivity of a water medium on the development of eer: $;$ of the Atlantic salmon. Tr. Folyar. Nauch.-Issled. Froekt. Inst. Worsk. Ryb. Khoz. Okeanogr. (29;: 91-103. (EnElish transl. AIC-tr-7418). (HAs 27-28004).

Fiiel, G. $K$. 1969. Addition of automatic temperature and pressure sensors to underwater gamma spectrometer. Naval Ordinance Lab., White Oak, Md. U. $\$$. AEC report TID-2.5484. $20 \mathrm{pp}$. (NSA 24-46527).

datson, D. G. and W. L. Templeton. 1973. Thermoluminescent dosimetry of aquatic organisms. pp. 1125-1130. In: Radionuclides in Ecosystems. (D. J. Nelson, ed.). U. S. AEC report CONF-710501-P2.

Woodhead, D. S. 1970. The assessment of the radiation dose to deveioping fish embryos due to the accumulation of radioactivity by the ege. Radiation Res. 43(3): 582-597. (NSA 24-50923).

Woodhead, D. S. 1973. Levels of radioactivity in the marine environment and the dose commitment to marine organisms. py. 499-524. In Radioactive Contamination of the liarine Environment. Intern. A tomic Energy Agency, Vienna, Austria, publication STI/PUB-313. (NSA 28-8184). 
Woodhead, D. S. 1973. The radiation dose received by plaice (Fleuronectes platessa) from the waste discharged into the north-east Irish sea from the fuel reprocessing plant at windscale. Health Phys. 25(2): $115-121$.

Hoodhead, D. S. 1974. Estimation of radiation dose rates to fish in contaminated environments and the assessment of the possible consequences. pp. 555-575. In: Population Dose Evaluation and Standards for lian and His Environment. Intern. Atomic Energy Agency, Vienna, Austria, publication SII/FUB-375. (NSA 31-19591).

Hoodhead, D. S. et al. 1976. Concentrations of radionuclides in aquatic environments and the resultant radiation dose rates received by aquatic organisms. pp. 3-54. In: Effects of Ionizing Radiation on the Aquatic Organisms and keosystems. Intern. Atomic Energy Agency, Vienna, Austria, Tech. Repts. Series No. 172 . 
ECOLOGICAL ASPECTS OF RADIOACTIVE WASTE DISFOSAL INTO THE SEA ; SONE GENERAI REFERENCES

\author{
Vincent Schultz \\ Department of 200logy \\ washington State University \\ Pullman, Washington \\ Puliman, Washington
}


Ancellin, J, No date. Marine radioesology. pp. 197-202. In! 8th National Congress on the Control of Ionizing Radiations. Ecole Centrale des Arts et Nanufactures, Chatenay-Malabry, France. (In French) (NSA 33-3006). (Includes sea disposal).

Ancellin. J, 1973. Froblems associated with the disposal of radioactive wastes in the sea. Agriculture (Paris) (366), 181-183. (In French) (NSA 29-15569).

Anderson, D. R. et al. 1975. Release pathways for deep seabed disposal o* radioactive wastes. pp. 483-502. In: Impacts of Nuclear Releases into the Aquatic Environment. Intern. Atomic Energy AEency, Vienna, Austria, publication STI/PUB/406.

Anonymous. 1967. Radioactive waste disposal operation into the Atlantic. Europeen Nuclear Energy Agency, Paris. 74 pp. (NSA 22-51121).

Anonymous, 1971. Radionuclides in the sea. Intern. Atomic Energy Agency Bull. 13(1): 26-31. (NSA 2532403).

Anonymous. 1972. Disposal of Radioactive Waste. Proceedings of the Information Heeting. Paris, April 1214. 1972. Organization for Economic Co-operation and Development, Paris, report CONF-720453. $294 \mathrm{pp}$. (In French and English) (NSA 28-6463).

Anonymous. 1973. Setting limits on marine pollution. Bull. Intern. Atomic Energy Agency $15(4): 39-41$.

Anonymous. 19,4. Guidelines for sea disposal packages of racioactive Waste. Nuclear Energy Agency, Paris. 27 pp. (NP-20310). (NSA 31-23437). (Deep sea disposal).

Aoyama, I., M. Yamamoto and Y. Inove. 1977. Evaluation of the radioactive wastes disposal into the deep ocean. Health Phys. 33(3), 227-240.

Avargues, $M$. No date. Study of a maritime site with the view of disposal of radioactive waste. Commissariat - I'Energie Atomique, Centre d'Etudes Nucleaires, Fontenay-aux-Roses, France, report CEA-CONF-1876. 6 pp. (In French) (NSA 26-22816). 
Bernhard, M. 1970. Evaluation of the risks rejated to the discharge of radioactive isotopes in a marine ecosysten. I. A comparison between the concentration factor approach and the specific activity approach. Rev. Intern. Oceanogr. lied, 20, 125-131. (NSA 288180).

Blaylock, B. G. and J. P. Witherspoon. 1976. Rediation doses and effects estimated for aquatic biota exposed to radioactive releases from IVR fuel-cycle facilities. Nuclear Safety 17(3): 351-361. (ERA 1-24759).

Bogorov, V. G, and E. M. Kreps. 1958. Concerning the possioility of disposing of radioactive wastes in ocean trenches. Froc. 2nd UN Intern. Conf. on the Peaceful Uses of Atomic Energy 18: 371-375.

Bogorov, V. G. and Ye. M. Kreps. 1958. Radioactive waste disposal in the abyssal depth of the ocean. Friroda (9): 45-50.

Bogorov, V, G. and B. A. Tareev, 1960. Ocean depths and the problem of burying radioactive wastes in them. Izv. Akad. Nauk SSSR (geofiz.) (4), 3-10. (English transl. JPRS 4,103).

Bogorov, V. G, and N. I. Popov, 1963. Problems of global radioactive contamination of the raters of the world oceans. State Committee on the Use of Atomic Energy, USSR. Hoscow. Atomizdat. UN Document A/AC.82/G/I.

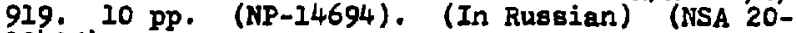
29405).

Bogorov, V. G., B. A. Tareyev and K. N. Fedorov. 1960. The dupths of the ocean and the question of radioactive waste disposel in them. pp. 210-217. plus references, p. 209. InI Disposal of Radloactlve ilastes, Vol. 2 . Intern. Atomic Energy Agency, Vienna, Austria, publication STI/PUB/I8.

Bowles, P., R. H. Burns, F. Hudswej.I and R. T. P. Whipple. 1958. Sea disposal of low-activity effluent. Proc. 2nd UN Intern. Conf, on the Peacerul Uses of Atomic Energy 18, 376-389.

Brenca, G. 1972. Linrine dieposal of solid radionctive wates. A gurvey of world operations. Ing. Sanit. $20(2), 63-76$. (In Italian) (ISA 28-13403). 
Brown, E. D. 1971. International law and marine pollution: Radioactive waste and other hazardous substances. Natural Resources J. II(2), 221-255.

Brown, J. M., Jr., J. F. Thompson and H. I. Andrews. 19ó2. Survival of waste containers at ocean depths. Health Phys. $7(3 / 4): 227-228$.

Carritt, D. E. 1960. Disposal into the sea and into geological structures of wastes resulting from the peaceful uses of atomic energy. pp. 259-264. In: Disposal of Radioactive Wastes, Vol. 2. Intern. Atomic Energy Agency, Vienna, Austria, publication STI/PUB/IB.

Chipman, W. A. 1959. Disposal of radioactive materials and its relation to fisheries. Proc. Natl. Shellflasheries Assoc. 49, 5-12.

Committee on OceanoEraphy. 1959. Radioactive waste disposal into the Atlantic and Gulf coastal waters. National Academy of Sciences - National Research Council, ilashington, DC., publication 655. viii, $37 \mathrm{pp}$.

Committee on Dceanography. 1962. Disposal of low-level radioactive waste into Pacific coastal waters. National Academy of Sciences - National Research Council, Washington, DC., publication 985 . xil, $87 \mathrm{pp}$.

Craig, H. 1957. Disposal of radioactive wastes in the ocean: The fission product spectrum in the sea as a function of time and mixing characteristics. $p p$. 34-42. In The Effects of Atomic Radiation on Oceanography and Fisheries. National Academy of Sciences - National Research Council, Washington, DC., publication 551 .

Dunster, H. J. 1958. The disposal of radioactlve liquid wastes into coastal waters. Froc. 2nd UN Intern. Conf. on the Feaceful Uses of Atomic Energy 18: 390-399.

Duursma, E. K. 1973. Specific activity of radionuclides sorbed by marine sediments in relation to the stable element composition. Radioact. Sea No. 331 57-7l. (NSA 33-29109). (Concerns waste disposal). 
Fair, D. R. R. and A. S. Hetean. 1956. The disposal of mote products into the sea. Part 3. The experimental discharge of radioactive effluents. Proc. Intern. Conf. on the Peaceful Uses of Atomic Energy 9, 716717.

Fedorova, A. F. and V. N. Podimakhin. 1962. The world ocean should be protected from radioactive contamination. Priroda 11: 47-50.

Fountaine, H. 1956. The oceans and the dangers resulting Irom the use of atomic energy. J. Cons. Intern. Explor. Mer 21(3), 241-249. (In French).

Frye, A. 1962. The hazards of atomic vastes: Perspectives and proposals on oceanic disposal. Public Affairs Press, Washington, DC. iv, $45 \mathrm{pp}$.

Gennel, I. 2965. The Brookhaven experience with sea disposal of radioactive wastes. pp. 153-16I. In: Sanitary Enginecring Aspects of the Atomic Energy Industry, a seminar held at the Robert A. Taft Engineering Center, Cincinnati, Ohio, December 6-9, 1955. Part la. U. S. AEC report TID-7517.

Gordon, D. I. 1960. Some hydrographic studies required for assessing the effects of atomic waste disposal. pp. 226-228. Ins Disposal of Radioactive Wastes, Vol. 2. Intern. Atomic Energy Agency, Vienna, Austria, publication STI/PUB/18.

Heath, G. R.. 1975. Seabed disposal programi Geochemical and gedimentological studies of North Pacific gediments. Progress report, July 1, 1975 - September 30, 1975. Fhode Island Univ.. Kingston. Contract E(11-1)-2689. 4 pp. (CO0-2689-2). (ERA 1-7359).

Hedgpeth, J. W. and H. T. Farvar. 1972. Atomic waste disposal in the sea, An ecological dilemma. Pp. 812-828. In: Careless Technology: Ecoloby and International Development. (H. T. Parvar and J. P. Milton, eds.). Natural History Press, Garden City, IIY. (NSA 28-2983).

Hollister, C. D., D. R. Anderson and D. M. Talbert. 1976. First international workshop on seabed disposal of high-level wastes. pp. 639-657. In: Proc. Intern. Symp. On the Nanagement of Wastes from the LWR fuel cycle. U. S. ERDA report CONF-760701. (ERA 2-21837). 
Hunzinger, 4. 1975. Safety aspects of sinking radioactive waste into the sea. Meerestechnik $6(1): 23-$ 27. (In German) (NSA 33-15371).

Hydeman, I. $M_{\text {. }}$ and $W, H$. Berman. 1960. Iegal and administrative problems of controlling the disposal of nuclear wastes in the sea. pp. 565-571. In: Disposal of Radioactive Hastes, Vol. 1. Intern. Atomic Energy Agency, Vienna, Austria, publication STI/PUB/18.

Ichikawa, R. 1970. Problems of marine disposal of radioactive waste. Genshiryoku Kogyo $16(7), 20-24$. (In Japanese) (NSA 25-4316).

International Atomic Energy Agency. 1961. Radioactive Waste Disposal into the Sea. Vienna, Austria, Safety Series No. 5. 174 pp. (STI/PUB/14).

Knizhnikov, V. A, and R. M. Barkhudanov, 1975. Radioactive contamination of the environment and the possible consequences. Atomic Energy Rev. 13(2), $171-214$.

Kullenberg, G. E. B. 1975. Ocean dumping sites. Ocean Manage. 2(3): 189-209. (NSA 32-17910).

Irevastu, T. 1959. Marine biology and the disposal of radioactive wastes in the sea. Inst. Sci. Mag. Bombay 28: 59-61.

Lowenstein, R. 1961. Some legal considerations in the ocean disposal of radioactive wastes. Health Phys. $6(3 / 4)$; $110-113$.

Lowman, F. G. 1975. Radioactive waste in the marine environment. U. S. ERDA report TID-26833. 17 pp. (NSA 32-14276).

Lowman, F. G. 1976. Radioactive waste in the marine environment. pp. 273-2B9. In: Energy and the Environment Cost-Benefit Analysis. (R. A. Karam, ed.). Perganon Press, Elmsford, NY. (ERA 2-30887).

Biakihara, K. 1969. Radioactive contamination of the ocean. J. Pollution Control 5, 255-263. (In Japanese) (NSA 24-9625).

Miyake, Y. 1963. Radioactive contamination of the sea. Problems in the disposal of radioactive wastes in the sea. Shizen 18(8), 22-27. (In Japanese) (NSA 18-1(503). 
Morgan, F. 1960, Pisheries radioblology of the discharge of radioactive wastes. pp. 17-24. In: Disposal of Radioactive Wastes, Vol. 2. Intern. Atomic Erergy Agency, Vienna, Austria, publication STI/PUB/18.

National Committee on Radiation Protection. 1954. Radioactive waste disposal in the ocean. National Bureau of Standards Hardbook 58. Washington, DC. 31 pp.

Nielsen, S. 0. 1974. Nuclear waste disposal in the oceans. Science 185(4157), 1183. (NSA 30-30110).

Odum, E. P. 1956. Consideration of the total environment in power reactor waste disposal. Proc. Intern. Conf. on the Peaceful Uses of Atomic Enerby 13, 350-353.

Olivier, J. P. 1975. Sea disposal of packaged radioactive wastes. pp. 255-256. In: Ia Maturite de l'Energie Nucleaire. ( $J$. Iehoulier and M. Vantega, eds.). Societe Francaise de I'Energie Nucleaire, Clamart, France. (In Fronch) (NSA 32-22967).

0livier, J. P. 1976. Off-shore discharge of radioactive wastes. Rev. Gen. Nucl. (6), 513-519. (In French) (ERA 3-21781).

Pearce, K. W. and J. D. Vincent. 1963. Investigation into the effects of deep sea pressures on waste materials and disposal containers. United Kingdom Atomic Energy Authority, Harwell, report AERE-Iil-1254. 29 pp. (NSA 21-36173).

Pelzer, N. 1970. Legal problems in the disposal of radioactive wastes in the sea. An international legal and comparative law investigation. Studies of International Economic Laws and Atomic Energy Laws. Vol. 41. $278 \mathrm{pp}$. (In German) (NSA 25-44576).

Polvanf, C. 1969. Radioactive solid waste disposal into the oceans: Implications and perspectives. Comitato Nazionale per 1 'Energia Nucleure, Rome, Italy, report RT/PROT-(70)-34. 20 pp. (NSA 26-299).

Pontavice, E. 1975. Radioactive merine pollution. pp. 119-137. In! Muclear Inter Jura 75 Proc. Intern. Nuclear Law ABsoc., Paris. (In French) (ERA 2-24122). 
Preston. A. 1975. The radiological consequences of releases from nuclear facilities to the aquatic environment. pp. 3-2l. Ins Impacts of Nuclear Releases into the Aquatic Environment. Intern. Atomic EnerES Agency, Vienna, Austria, publication STI/PUB/406.

Pritchard, D. W. 1958. Factors affecting the dispersal of fission products in estuarine and inshore environments. Froc. 2nd UN Intern. Conf. on the Peaceful Uses of Atomic Energy 18; 410-413.

Pritchard, D. H. 1960. The application of existing oceanographic knowledge to the problem of radioactive waste disposal into the sea. pp. 229-248. In: Disposal of Radioactive iastes, Vol. 2. Intern. Atomic Enerey Agency, Vienna, Austria, publication STI/PUB/18.

Pritchard, D. W. 1961. Disposal of radioactive wastes in the ocean. Health Phys. 6(3/4): 103-109.

Renn, C. E. 1956. Disposal of radioactive wastes at sea. Proc. UN Intern. Conf. on the Peaceful Uses of Atomic Energy 9:718-721.

Renn. C. E. 1956. Ultimate disposal of radioactive reactor wastes in oceans. J. Amer. Water Works Assoc. $48(5): 535-537$.

Revelle, $R$. 1959. Research needed to evaluate the effects of radioactive material in the marine environnent. pp. 1299-1323. In: Industrial Radioactive Waste Disposal, Hearings before the Special Subcommittee on Radiation, Joint Committee on Atomic EnerEy, U. S. Congress, Vol. 2, Washington, DC.

Revelle, R. and H. B. Schaefer. 1957. General considerations concerning the ocean as a receptacle for artifically radioactive materials. pp. 1-25. In: The Effects of Atomic Radiation on Oceanography and Fisheries. National Academy of Sciences - National Research Council, Washington, DC, publication 551.

Revelle, R. and M. B. Schaefer. 1958. Oceanic research needed for safe disposal of radioactive wastes at sea. Proc. 2nd UN Intern. Conf. on the Peaceful Uses of Atomic Inerey $18,364-370$. 
Revelle, R., T. R. Folsom, E. D. Goldberg and J. D. Isaacs. 1956. Nuclear science and oceanography. Proc. UN Intern. Conf. on the Peaceful Uses of Atomic Energy 13: $371-380$.

Robinson, B. P. 1962. Ion-exchange minerals and disposal of radioactive wastes - a survey of literature. U.S. Geological Survey Hater, Suppl. Paper 1616. 132 pp.

Saddington, K. S. and W. I. Templetor. 1958. Disposal of Radioactive Hastes. George Newnes Itd., Iondon. x, $202 \mathrm{pp}$.

Schaefer, II. B. 1961. Some fundamental aspects of marine ecology in relation to radioactive wastes. Health Phys. 6(3/4), 97-102.

Templeton, W. I. 1959. Fission products and aquatic organisms. pp. 125-140. In: The Effects of Pollution on Living Material, 8th Symposia. Institute of Biology, Iondon. (NSA 16-19210).

Templeton, W. I. 1965. Ecological espects of the disposal of radioactive wastes to the sea. pp. 65-97. In: Bcology and the Industrial Society. (G. T. Goodman, R. W. Edwards and J. M. Iambert, eds.). Blackwell Scientific Publications, Oxford.

United Nations. 1957. UNESCO/FAO/WHO report on sea and ocean disposal of radioactive wastes, including Appendices A, B, and C. Paris. $118 \mathrm{pp}$. (UNasco/ NS $/$ OCEAN $/ 76$ ).

Various authors. 1960. Discussion. pp. 293-320. In: Dioposal of Radioactive Wastes, vol. 2. Intern. Atomic Bnergy Agency, Vienna, Austria, publication STI/PUB/18. (Effects and waste disposal).

Walden, H. 1972. Overloading the sea with waste products. Studiengesellschaft zur Foerderung der Kernenergieverwertung in Schiffbau and Schiffahrt $E_{\text {. }} V_{\text {. }}$ Hamburg. west Germany, report NP-19706. 41 pp. (In German) (NSA 28-5529).

Wallace, B. 1974. Commentary: Radioactive wastes and damage to marine communities. Bioscience $24(3)$, 164267 . 
Webb, G. A. and F. Morley. 1973. A model for the evaluation of the deep ocean disposal of radioactive waste. National Radiological Protection Board, Harwell, Didcot, Berks, report NRPB-R14. 29 pp. (NSA 2822128).

Miscellaneous liaterials

Anderson, D. R. (ed.). 1978. The Third International Seabed High-Level Waste Disposal Assessment Workshop. Albuquerque, New liexico, February 6-7, 1978; a Report to the NEA Radioactive Waste ianagement Committee. Sandia Labs., U. S. DOE report SAND 78-0369. 199 pp.

Anderson, D. R. et al. 1978. Release pathways for deep seabed disposal of radioactive wastes. Sandia Labs.. U. S. DOE report SAND 74-5854. (i), $25 \mathrm{pp}$.

Anonymous. 1975. Ocean waste disposal. A bibliography with abstracts. Search period covered 1964 -illay, 1975. Aircraft Nuclear Propulsion Dept.. General Electric Co., Cincinnati, Ohio, report NTIS/PS-75/462. $214 \mathrm{pp}$. (NSA 32-27974).

Bishop, W. P. and C. D. Hollister (eds.). 1973. Program on the ocean basin floors and radioactive materials: Data bases for assessing preliminary concepts. Sandia Labs. , Albuquerque, New Hexico, U. S, AEC report SLA-73-596. 44 pp. (NSA 28-30706).

Bishop, W. P. and C. D. hollister. 1974. Nuclear wastes beneath the deep sea floor. Sandia Iabs., Albuquerque, New liexico, report SAND-74-5855. 19 pp. (NSA 3224717). (CONF-750830-1).

Bishop, W. P. and C. D. Hollister. 1974. Seabed disposal where to look. Nuclear Technol. 24: 425-443.

Blshop, W. P., D. R. Anderson and C. D. Hollister. 1974. Iuclear wastes in the deep seabed. Sandia Labs., Albuquerque, New hexico, report SAND-74-7017. $8 \mathrm{pp}$. (NSA 32-7238).

Brown, R. J. 1976. Ocean waste disposal (a bibliography with abstracts). Report for 1964-June, 1976. National Technical Information Service, Springfield, VA.. report NIIS/PS-76(0558). 236 pp. (ERA 2-29001). 
Davis, T. F. 1962, Radioactive waste processing and disposal. A literature search. U.S. AEC report TID-3555. 98 pp. (NSA 14-20042).

Davis, T. F. 1962. Radioactive waste processing and disposal. A literature search. U. S. AEC report TID-3555 (Suppl. I). 156 pp. (NSA 16-30157).

Davis, T. F. 1966. Radloactive waste processing and disposal. An annotated bibliography of selected iiterature. Division of Tech. Inform. Extension, U. S. AEC report TID-3311 (Suppl. 2). 182 pp. (NSA 21-8567).

International Atomic Enerby Agency. 1962. Disposal of radioactive wastes into marine and fresh waters. Vienna, Austria, Bibliographical series No. 5. $368 \mathrm{pp}$. (STI/PUB/21/5). (ISA 16-20040).

Laevastu, T. 1959. Bibliography on disposal of radioactive wastes into the sea. Intern. Atomic Enerey Agency, Vienna, Austria. $31 \mathrm{pp}$. (TO/HS/9).

Iehmann, E. J. 1974. Ocean waste disposal. A biblioGraphy with abstracts. Report for 1964 - June, 1974. National Information Service, Springfield, VA.. report NTIS-WIN-74-062. 146 pp. (NSA 31-4018).

Sasaki, T. and M. Okazaki. 1966. Studies of a container for disposing of radioactive wastes into the sea. VI. On the permeability and diffusion in mortar (2). Nippon Kaiyo Gakkaishi 22:245-254. (In Japanese) (NSA 21-26134).

Sasaki, T., S. Wattanabe, G. Oshiba, N. Okami and M. Kajhara. 1963. Studies on the container for disposing radioactive wastes into the sea. (Part I.). J. Oceanog. Soc. Japan 19, 16-26. (In Japanese) (NSA 17-29874).

Schneider, K. J. 1974. High level waste. pp. 187-233. In: Human and Ecologic Effects of Nuclear Power Plants. (I. A. Sagan, ed.). Charles C Thomas, springfield, IL. (NSA 30-23729). 
Schneider, K. J. and A. M. Platt (eds.). 1974. Highlevel radioactive waste management alternatives. Section 1. Summary. Section 2. Background and data base. Section 3. Evaluation methodology. Battelle Northwest Labs . . U. S. AEC report BNWL1900 (Yol. 1). 458 pp. (NSA 30-13295).

Schneider, K. J. and A. M. Platt (eds.). 1974. Highlevel radioactive waste management alternatives. Section 4. Geologic disposal. Battelle Northwest Labs.. U. S. AEC report BNWI-1900 (Vol. 2). 259 pp. (NSA 30-13296).

Schneider, K. J. and A. M. Platt (eds.). 1974. Highlevel radioactive waste management alternatives. Section 5. Ice sheet disposal. Section 6. Seabed disposal. Battelle Northwest Iabs., U. S. AEC report BW/L-1900 (Vol. 3). 310 pp. (NSA 30-13297).

Schneider, K. J. and A. M. Flatt (eds.). 1974. Highlevel radioactive waste management alternatives. Section 7. Waste partitioning. Section 8. Extraterrestrial disposal. Section 9. Transmutation processing. Battelle Northwest Labs., U. S. AEC report BNHI-1900 (Vol, 4), 463 pp. (NSA 30-13298).

Stanley, H. G. and D. H. Kaplanek. 1976. Bibliography on ocean waste disposal. Second edition. Final report, 1976. Interstate Electronics Corp., Anaheim, CA. Contract EPA-68-01-0796. $154 \mathrm{pp}$. (IEC-446-0C-0417). (PB-265831). (FRA 2-58527).

Terry, R. D. 1957. An annotated bibliography on bacteriology, oceanography, and marine geology as they relate to the disposal of waste material into the sea. University of Southern California, Los Angeles. $14 \mathrm{pp}$. 
EFFECTS OF IONIZING RADUITION ON AQUATIC ORGANISMS:

SELEGTED TABLES

by

Vincent Schultz

Department of Zoology

Washington State BnI versity

Puliman, Washington

1979 
Source: Blaylock, B. G. and J. R. Trabalka. 1978, Evaluating the effects of ionizing radiation on aquatic organiams. Advances in Radiation Biology 7: 103-152.

TADLE I

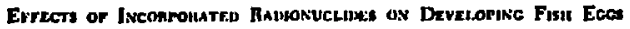

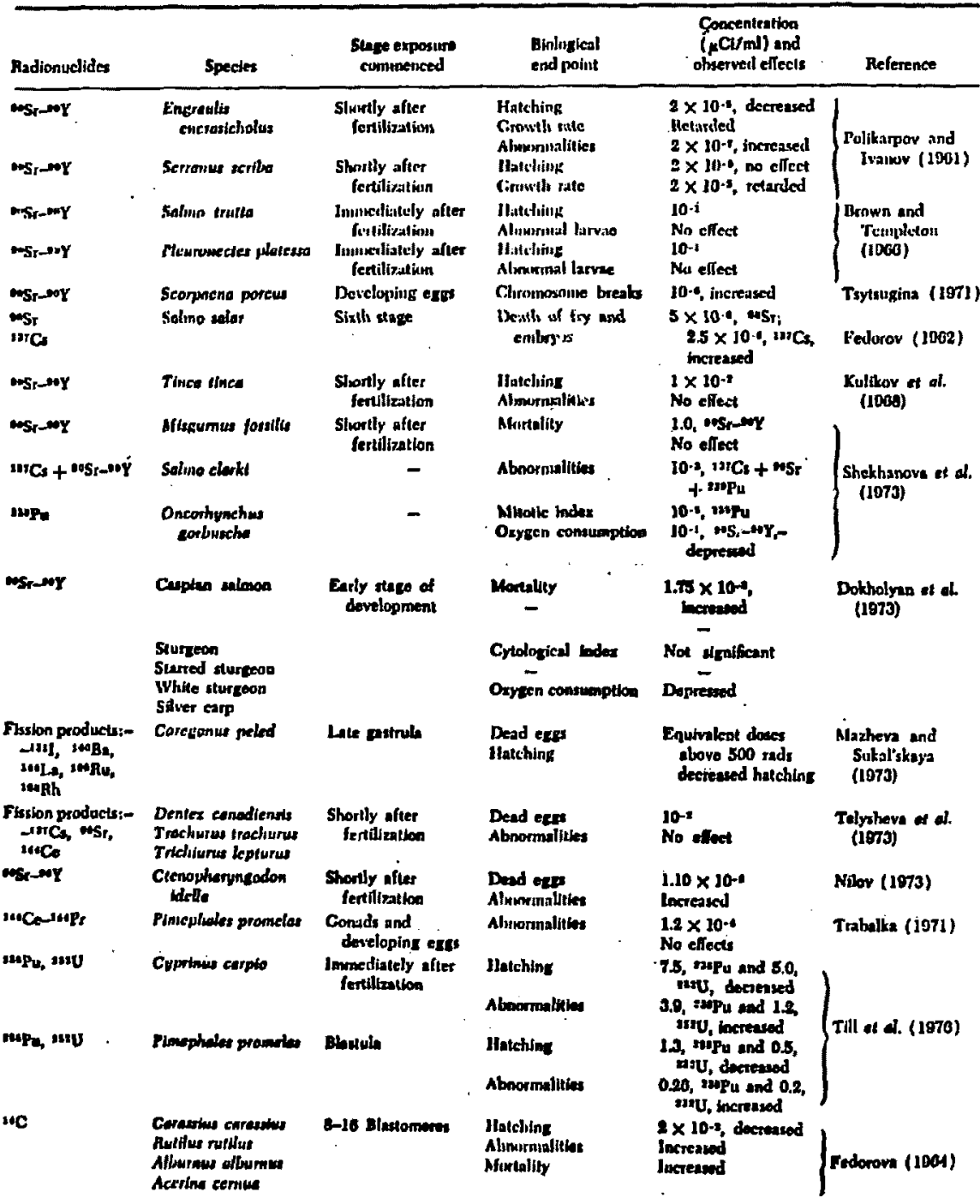


Table I. continued.

Source: Bloylock, B, G. and J. R. Trabalka, 1978. Evoluating the effects of lonitine radiation on aquatic oreanisms. Advances in ladiation iLiologs 7: 103-152.

TABLE 1 (Continued)

\begin{tabular}{|c|c|c|c|c|c|}
\hline Radionuclides & Snecies & $\begin{array}{l}\text { Stape erposure } \\
\text { commenced }\end{array}$ & $\begin{array}{l}\text { Blolosical } \\
\text { end point }\end{array}$ & $\begin{array}{l}\text { - Comcentration } \\
\text { ( } \mu \bar{C} i / n d) \text { und } \\
\text { observed effects }\end{array}$ & Reforence \\
\hline 川I & $\begin{array}{l}\text { Coprtinus ampio } \\
\text { Cesterosteur } \\
\text { eculeofus }\end{array}$ & $\begin{array}{l}\text { Inmediately after } \\
\text { Sertlibation } \\
\text { Immediately after } \\
\text { fertilizatlon }\end{array}$ & $\begin{array}{l}\text { Jlatching } \\
\text { Mlortality } \\
\text { Alsnormalitles } \\
\text { Eyo diametor }\end{array}$ & $\begin{array}{l}518 \\
\text { No efiect } \\
2000 \\
\text { No effect } \\
1000 \text {, reduced }\end{array}$ & $\begin{array}{l}\text { Elaylack et al. } \\
\text { (1970) } \\
\text { Walden (1071) }\end{array}$ \\
\hline •II & Salno calrdact & $\begin{array}{l}\text { Immellately after } \\
\text { Iertilizantion }\end{array}$ & $\begin{array}{l}\text { Ilotching } \\
\text { Alsuorinalities }\end{array}$ & $\begin{array}{l}10 \\
\text { No efiects }\end{array}$ & $\begin{array}{l}\text { Strand at al. } \\
\text { (1073) }\end{array}$ \\
\hline था! & 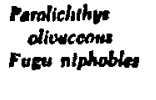 & $\begin{array}{l}\text { 10.Cell sthese } \\
\text { 2-Cell sage }\end{array}$ & $\begin{array}{l}\text { Ilulching } \\
\text { Heaching }\end{array}$ & $\begin{array}{l}10 \\
\text { Nis efiext } \\
10 \\
\text { Decreased }\end{array}$ & $\begin{array}{l}\text { Ichikawa and } \\
\text { Suyama (1074) }\end{array}$ \\
\hline $\mathbf{H I}$ & Solmo calrdher & $\begin{array}{l}6 \text { las After } \\
\text { fertilinstion }\end{array}$ & $\begin{array}{l}\text { Imonune response of } \\
\text { fry }\end{array}$ & $\begin{array}{l}1 \\
\text { Suppicised }\end{array}$ & $\begin{array}{c}\text { - Strand at al. } \\
\text { (1073) }\end{array}$ \\
\hline
\end{tabular}


Soiurce: Howen, V. T., J. S. OIsen, C. L. Osterbert and J. Ravera. 1971. Chp. 8. Ecolorical interactions of marine radioactivity. pp. 200-222. In: Radionctivity in the Yarine Environment, National Acadeny of Sciences, Washington, DC.

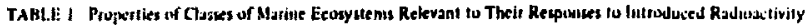

\begin{tabular}{|c|c|c|c|}
\hline Riomity & $\begin{array}{l}\text { Prugk: } \\
\text { Open Ocens }\end{array}$ & Oellici & $\begin{array}{l}\text { Meat-Shote: } \\
\text { Menthe and felogue }\end{array}$ \\
\hline Adworptine wefluces & Largaty blotopical & 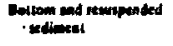 & 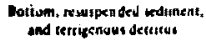 \\
\hline Fyricocthemical stability & Quite wrobs: & Vary ruste. & Masimum variability \\
\hline Puductivity & 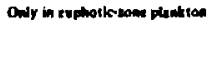 & Nom & 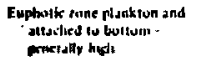 \\
\hline Poomuly autrixath twpaly & Leredy by wotel adxies & Nat bereatsin & 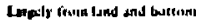 \\
\hline 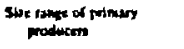 & Musty motroveole & - & Smoll 10 very larue \\
\hline Situ tame of tertiviteres & Manty yun & - & Monente to is re \\
\hline Food chio tresth mane & Motty base & Mosimene & smal \\
\hline Pupulativa molulity & Maximim- Mestion br & 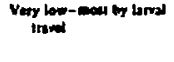 & Eutb hiph and low \\
\hline $\begin{array}{l}\text { Acotribitify to nem, both } \\
\text { expluitation an effects }\end{array}$ & 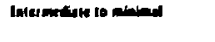 & Whinallat & Manted \\
\hline
\end{tabular}


Source: Chipman, :. $\Lambda_{0}$ i972. Ionizing, radiation, pn, 1579-1657. In: Marine licolory,
Volume I, Part 3. (0. Kinnc, ed.). Wilcy-Interscience, NY.

Talsle $11+3$

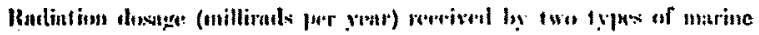

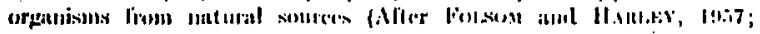
morlitic:d)

\begin{tabular}{|c|c|c|c|c|}
\hline \multirow{2}{*}{$\begin{array}{l}\text { Type of arganistul and } \\
\text { its kneution in tle sera }\end{array}$} & \multicolumn{3}{|c|}{ Typt of sndintion } & \multirow{2}{*}{$\begin{array}{l}\text { Appros: } \\
\text { tneal } \\
\text { dust }\end{array}$} \\
\hline & Cormic & Seu & Juternal & \\
\hline \multicolumn{5}{|l|}{ Large fislice } \\
\hline Near sea slurfaco & 35 & $0 \cdot 8$ & 28 & 64 \\
\hline At 300 in diptli & 0.5 & $0 \cdot 9$ & 28 & 30 \\
\hline 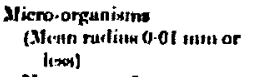 & & * & & \\
\hline Nonria-asiarfuco & 35 & $3 \cdot 6$ & $-\bullet$ & 30 \\
\hline At IfHInalinath & $0+5$ & $7 \cdot 6$ & $-\bullet$ & .3 \\
\hline 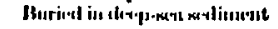 & 11.0150 & 40 tiene. & $-\bullet$ & $111-1120$ \\
\hline
\end{tabular}

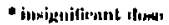

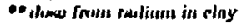


Source: Cosgrove, G. E., B. G. Blaylock, G. U. Ulrikson and P. H. CohEu. 1975. Radiation-induced hematopoietic lesions in fish. pp. 463-476. In: The Patholowy of Fisies. (V. E. Ribelin and G. Migak1, eds.). Univ. of Wisconsin Press, Madison.

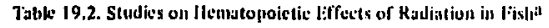

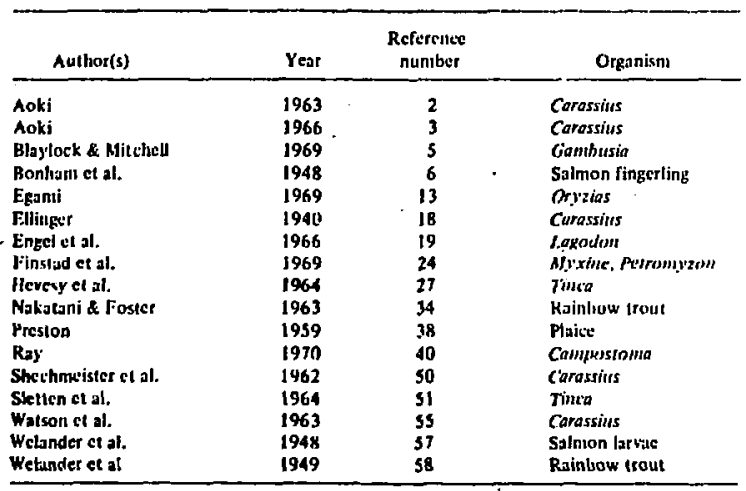

aReviews and special articks are not included. Other w tistes are lisled in the References. 
Source: Gochas'd, $K_{0}$ B. E. 2962. Invisible radiations. pp. 551-566. In:

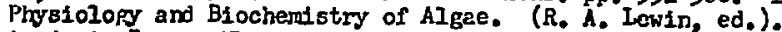
Academic Preso, II.

\section{TABIE III}

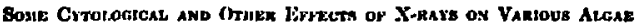

\begin{tabular}{|c|c|c|c|}
\hline Effect & $\begin{array}{l}\text { Dowe } \\
\text { (in rocatgend } \\
\times 100)\end{array}$ & Alo & Rofrresice \\
\hline None & $\begin{array}{r}2 \\
3 \\
10 \\
10\end{array}$ & 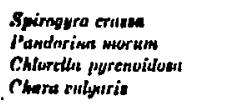 & 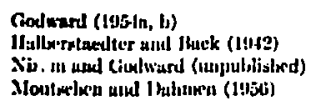 \\
\hline Alwormal cells & 10 & Chlordla rulgnris & T'kitscluatain (19isit) \\
\hline 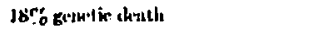 & H) & 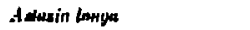 & Feloxenlnotn (1:51) \\
\hline 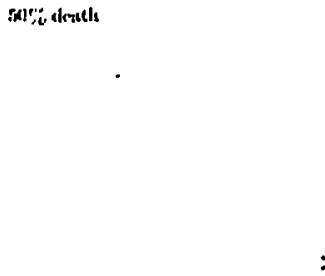 & $\begin{array}{l}0.75 \\
8 \text { (hard) } \\
11 \\
12 \\
10 \\
18 \\
28 \\
+10(\cos t) \\
45 \\
>100\end{array}$ & 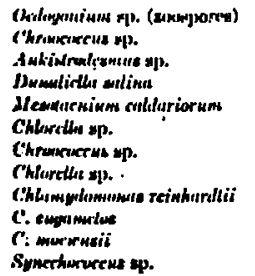 & 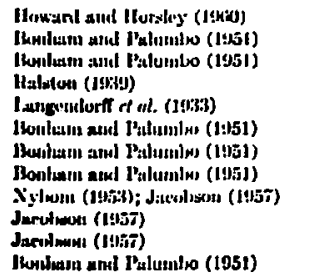 \\
\hline Dentlt on division & 5 to 300 & Pundorinu warum & IInlberstaceder atid liack (19-42) \\
\hline Vialste zanucte formation mipnoened & +0 & Acetabularia meditarenea & Six (11:38) \\
\hline Negencration Mi'phrewed & 400 & A cedebulurias nedilcrounou & Six (145B) \\
\hline 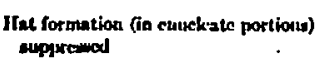 & 50 to 100 & Acatalularia meniterraned & $8 i x(1956)$ \\
\hline $\begin{array}{l}\text { "Ultimate survival" (as befined is } \\
\text { "ext) } \\
\text { "Immediste" death }\end{array}$ & $\begin{array}{r}15 \\
100 \\
000 \\
10 \\
000 \\
750\end{array}$ & 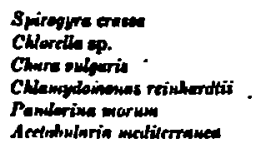 & 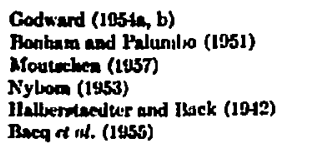 \\
\hline
\end{tabular}


Source: Ophel, I. I. et al. 1976. Chp. 2. Fifects of fonizing radiation on aquatic orpanisms. pp. 57-86. In: Effects of Ionizing Radiation on Aquatic Organisms and Ecosystems. Intern. Atomic Knersy Azency, Vienna, Austria, Teeb. Repts. Scries No. 172. (STI/DOC/10/172).

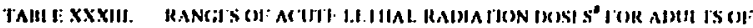

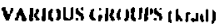

\begin{tabular}{|c|c|c|c|}
\hline Isucteria & 4.5 & -735 & $(1.1)_{w 1}$ \\
\hline the grein shest & $<460$ & $->1200$ & $\left.(L)_{10}\right)$ \\
\hline OHlltr ن & 3 & $\therefore \quad 120$ & $\left|t . b_{s, 0}\right|$ \\
\hline I'rutuases & $?$ & 600 & $(1.1)_{(0)}$ \\
\hline M'ollusiti & 20 & 109 & $\left(L D_{20 / \infty}\right)$ \\
\hline C'tublatitans & 1.5 & 56.6 & $\left(L D_{s 0 / x)}\right)$ \\
\hline Fishi & 1.1 & 5.6 & $\left(L U_{x y j}\right)$ \\
\hline
\end{tabular}

Mosily derived from Ref. [139].

TAULF. XXXIV." ACUTF BFTA DOSE ALLORING ULTHATE SURVIVAL OF Al Ginlikssul

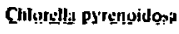

Anshytula $4 p$.

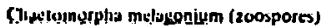

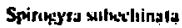

Mlisugeutiat sp?

Ryencund cslindrikum

Cosmọtioum suhtụminlum

Fudonima stutums

Spirowsira terts

C] Inclomorglis nislaponium

\section{0}

$100-200$

100

40

$20-50$

$20-50$

$20-50$

20- 50

is

10

- Afrer Goderad | 141]. 
Source: Ophel, I. L, et 8I. 1976. Chp. 2. Effects of iontrine radiation on aquatic organiame. pp. 57-96. In: Bffects of Ionizing Radiation on Aquatic Organisms and Leosystems. Intern. Atoric Ënerpy Apency, Vienna, Austria, Foch; Repts, Series No, 172. (STI/DOC/10/172).

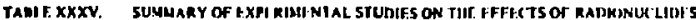
IN WATHR ON AOUATIC UKLANISHS

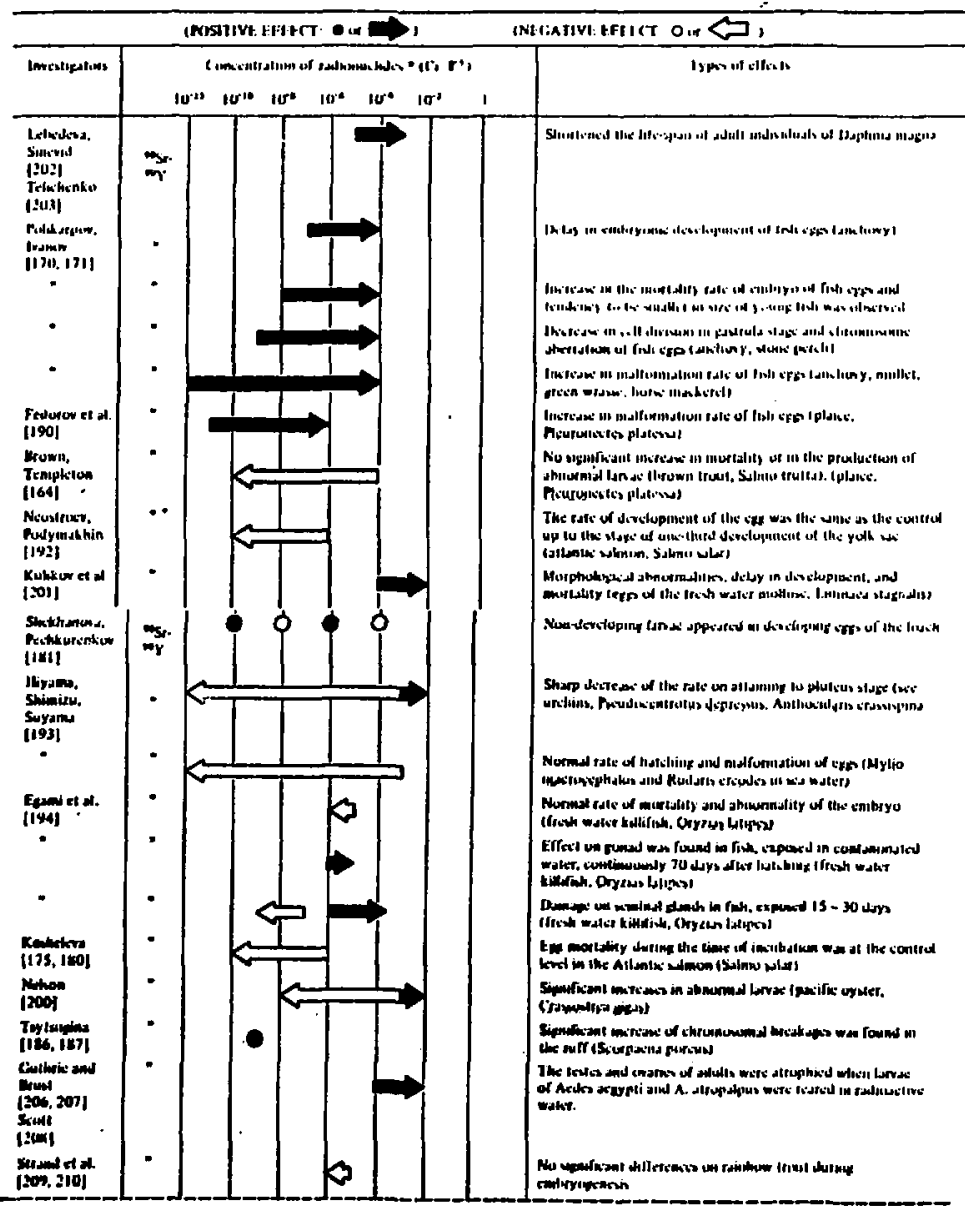


Table JYY. continued.

Sourcc: Ophel, I. J. et a]. 1976. Chp. 2. Erfects of loniaing radiation on aquatic organisms. op. 57-86. In: Frfects of Ionizing ladiation on Aquatic Organisms and Ecosystems. Intern. Atomic Energy Agency, Vienna, Austria, Tech. Repts. Series No. 172. (5TI/DOC/10/172).

IABt XXXV (contunued)

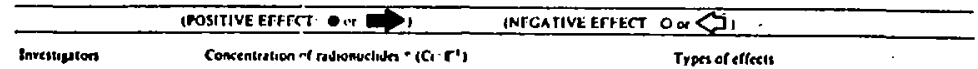

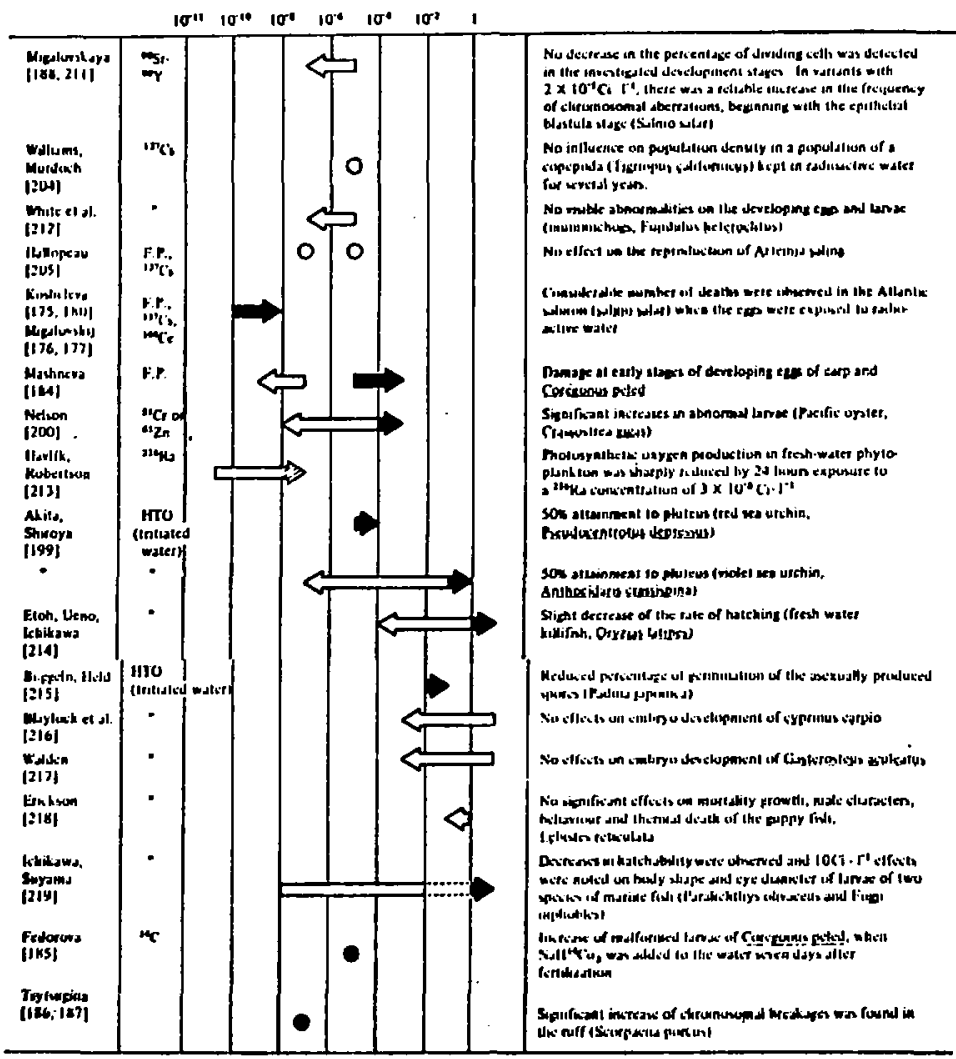

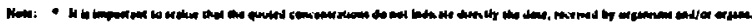


"ource: Poliksrpov, G. G. 1966. Part III. (continucd)

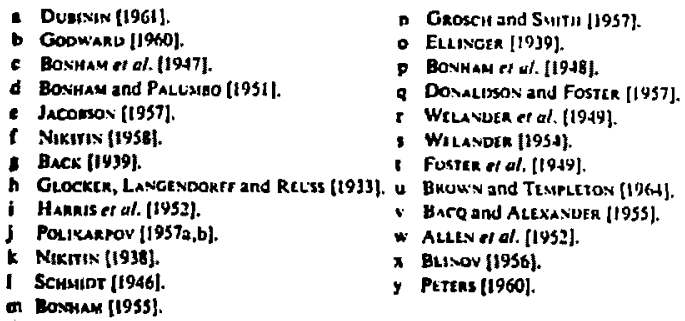


Source: Polikarpov, G. G. 1977. Effects of ionizing raviation upon aquatic organisms (chronic irradiation). Pp. 25-46. In: Atti della Giornata Sul rama Alcuni Aspetti di Radioecologia. XX Congresso Nationale, Associaziune Italiana di Fisica Sanitaria e Protezione Contro le Radiazioni, Bologna.

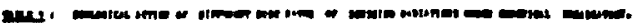

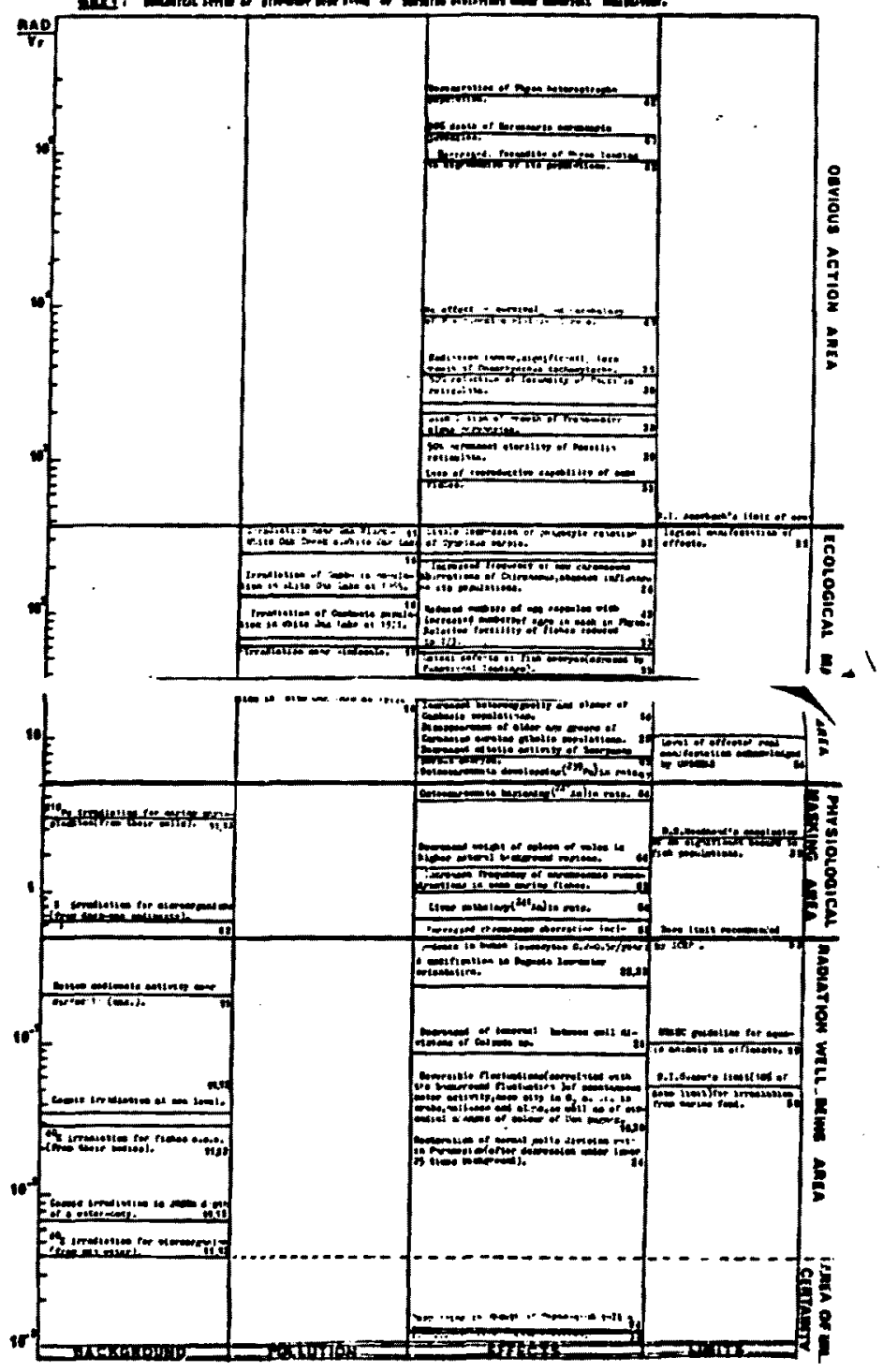


Source: Poltkarjov, U. G. 106.6. Part III. The effect of nuclear radistion on mrine orparifses. pp. 183-24\%. In: Radioccolory of Aquatic Orcanisms: the Accuriulation and Viologicel Effect of Hadioactive Gibstances. English translabion $7 n^{\prime}$ rovised edition. V. Sehultz and A. H. Kzement, Jr., eds. (Oriprinal: 196/. iladioccalofy of Marino Organisms. jitomizdat, Koscon, 295 pp.). North-Holland, Ainsterdam.

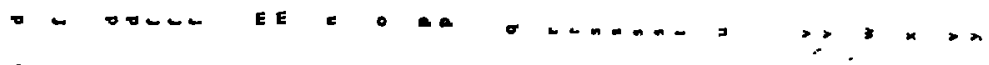

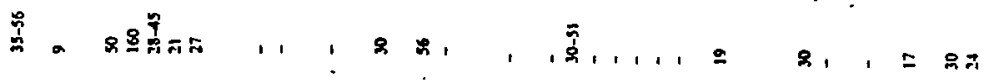

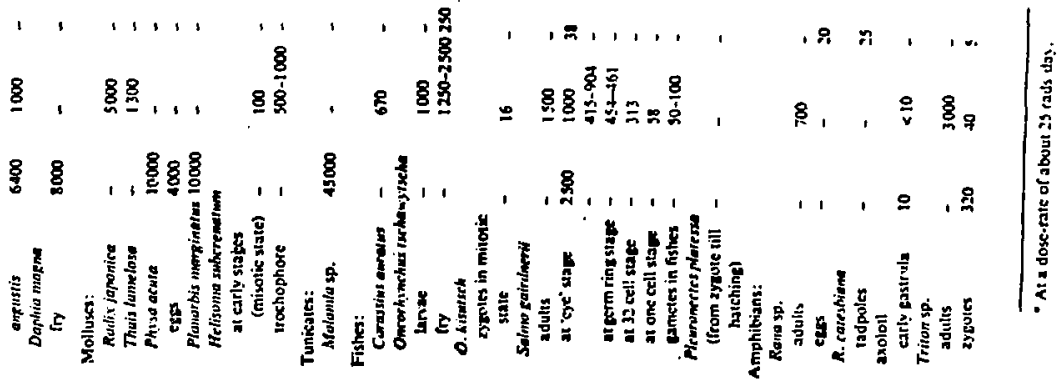

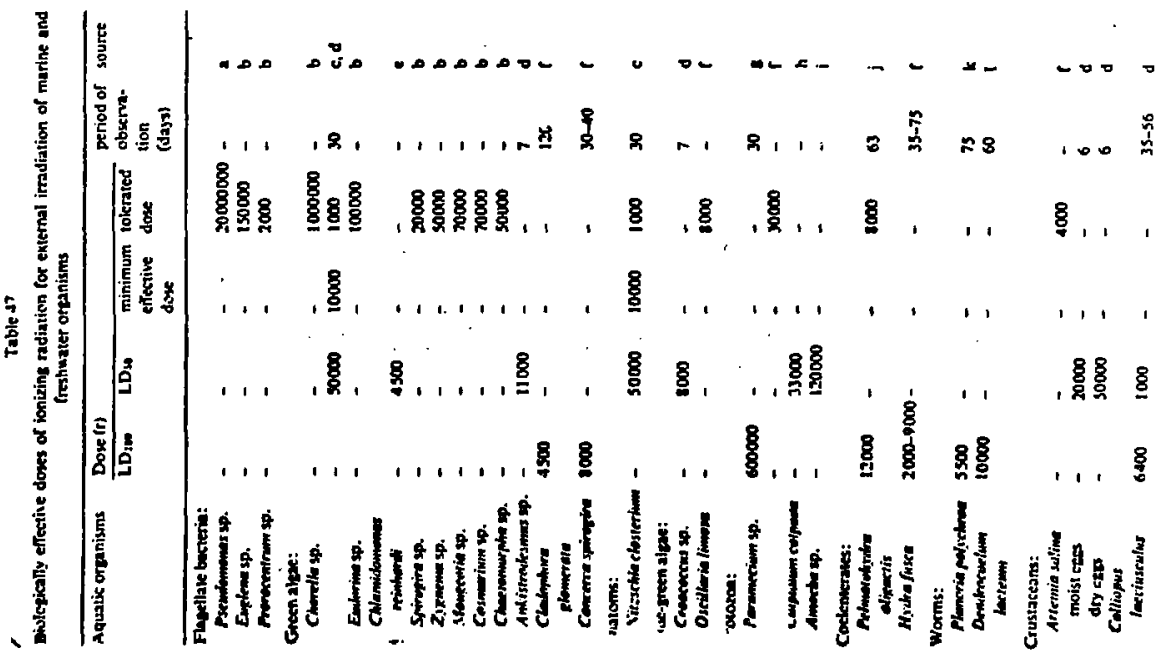




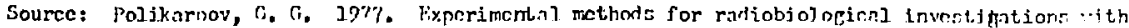

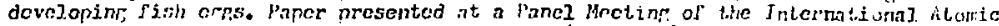
Fneres Aponcy, Vienn, hustria, October 1977. (In press).

Table 1. Radiobiological investigations of fishes apecies at acages of developing eggs in marine (M), hrackish (B) and fresh (F) water.

\begin{tabular}{|c|c|c|c|c|c|}
\hline Taxonomy & $\begin{array}{l}H, B \\
\text { or } F \\
\text { eater }\end{array}$ & $\begin{array}{l}\text { Sources of } \\
\text { ionizing } \\
\text { radiations }\end{array}$ & $\begin{array}{l}\text { Doses } \\
\text { (rad) }\end{array}$ & $\begin{array}{c}\text { Kadiunuclides } \\
\text { concentrations } \\
\text { (Ci/l) }\end{array}$ & Ref.: \\
\hline
\end{tabular}

\section{Class Osteichthyea}

Subclass Actinopterygii

Order Acipenseriformes

Fam. Acipenceridac

$$
\begin{aligned}
& 90 \mathrm{Sr} \text { (as we } 11 \text { as } \\
& 137 \mathrm{Cs} \text { and } 144 \mathrm{Cc} \text { ) }
\end{aligned} \quad 10^{-10}-10^{-6}
$$

Acipencer güldenstädti

A. B. persicus

External $1+$ oil $0.01-1 \mathrm{mg} / \mathrm{l}) \quad 800-9000$

\section{A. etellatus}

F External

10000

$10 \overline{7}$

Huso huso

$$
\begin{aligned}
& 90 \mathrm{Sr} \text { (as vel1 as } \\
& 137 \mathrm{Cr} \text { and } 144 \mathrm{Ce})
\end{aligned}
$$

$$
10^{-10}-10^{-6}
$$

Order Clupeiformes Suborder Clupeoidei

Fam. Engraulidae

$$
B, M \quad{ }^{90} \mathrm{Sr}
$$

$$
10^{-14}-10^{-4}
$$

Engraulis encracicholus

Suborder Salmonoidei

Fam. Salmonid ae

Salmo salar

External $\quad 50-350 \quad \not i 3 \overline{7}$

$$
\mathbf{F}
$$




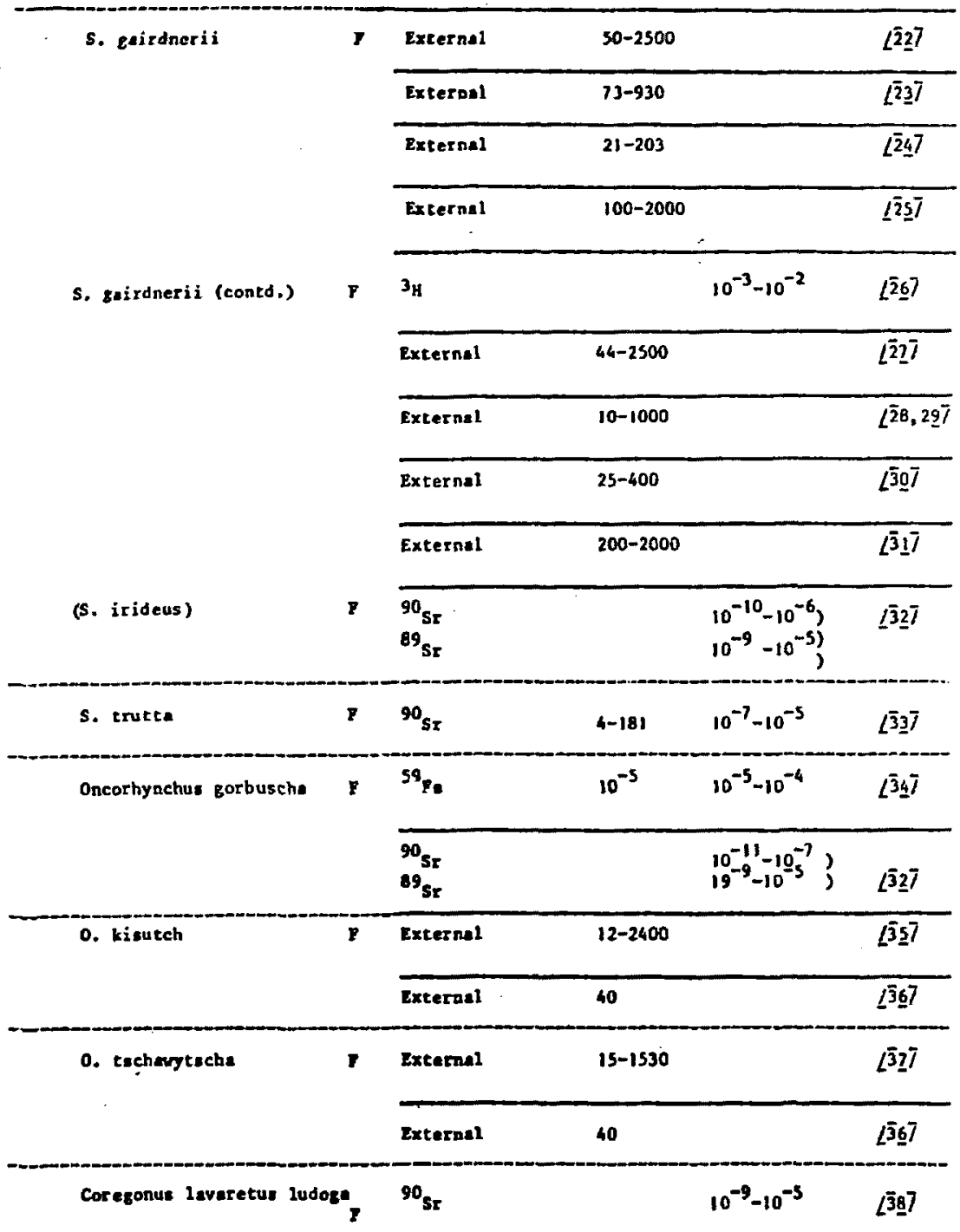




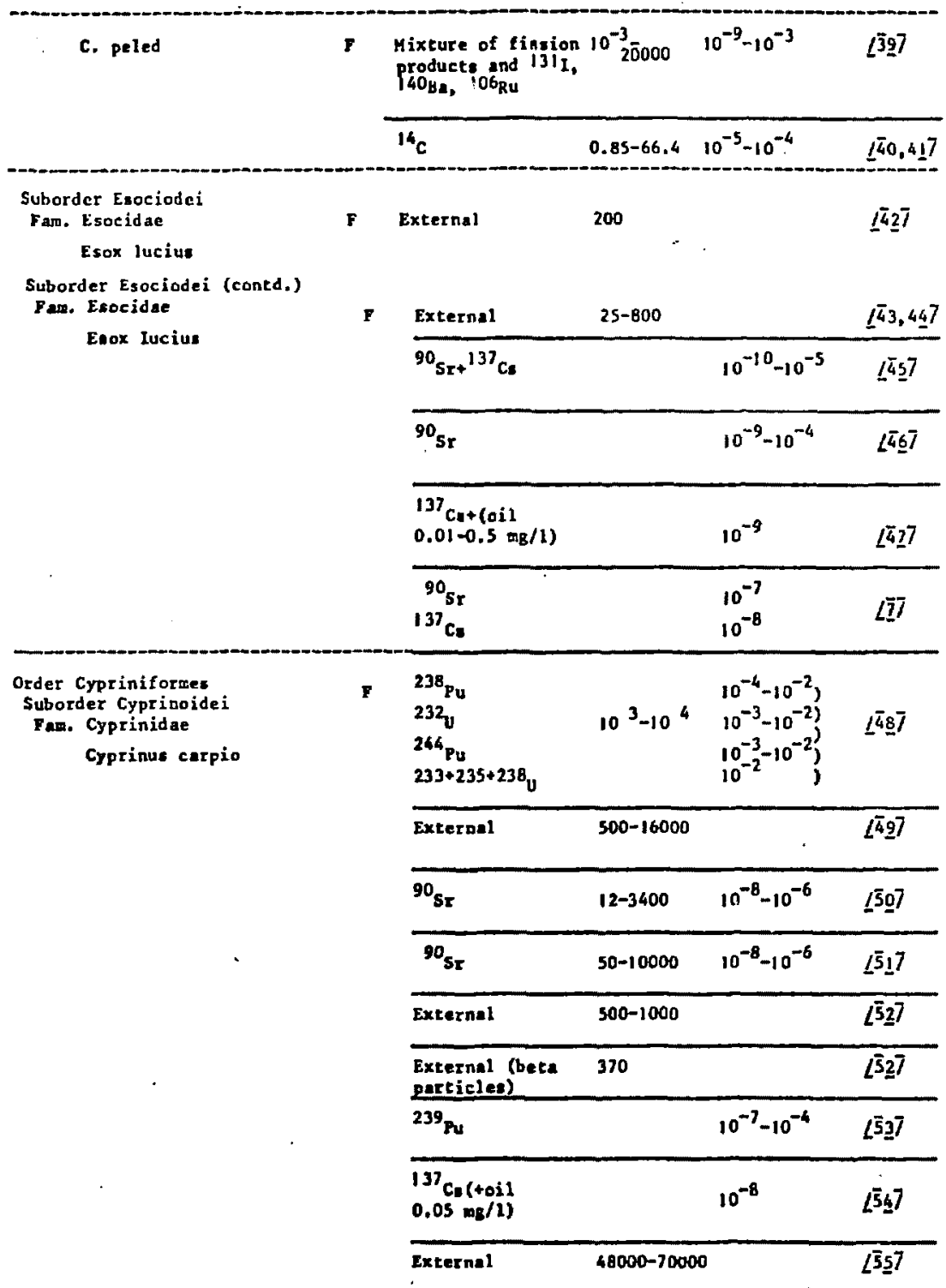




34 $10^{-5}$

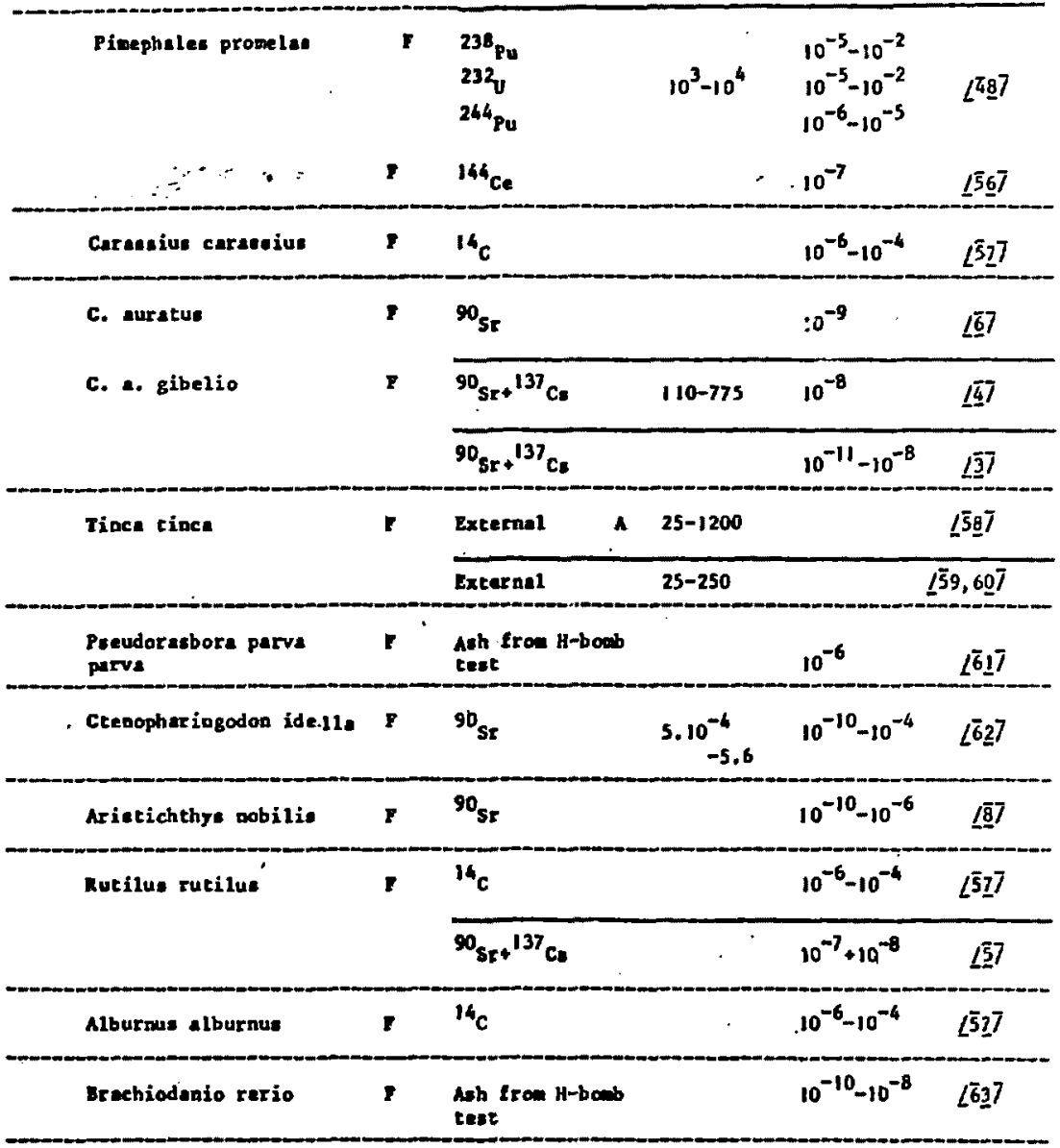

Fan. Cobitidee

Miscurnu fansilis

- External 100-3000

\begin{tabular}{lll}
\hline External & $10000 \quad\langle\bar{j} \bar{T}$
\end{tabular}




\begin{tabular}{|c|c|c|c|}
\hline External & $50-500$ & & {$[\overline{6} 57$} \\
\hline${ }^{90}{ }_{5 r}$ & 0.83 & $10^{-10}-10^{-4}$ & $1 \overline{6} 6 \overline{7}$ \\
\hline $\begin{array}{l}\text { External } \\
\text { (colchicine) }\end{array}$ & $1500-50000$ & & $\lfloor\overline{6} 27$ \\
\hline $90_{5 r}$ & $5.10^{-4}-50$ & $10^{-10}-10^{-4}$ & $\underline{6} 0 \overline{0}$ \\
\hline${ }^{239}{ }_{{ }^{90}}^{239^{+}}{ }^{90}{ }_{\mathrm{Sr}+}{ }^{137} \mathrm{Cu}$ & & $\begin{array}{l}10^{-11}-10^{-8} \\
10^{-10}-10^{-6} \\
10^{-10}-10^{-3}\end{array}$ & $1 \overline{6} 97$ \\
\hline $90_{\mathrm{Sr}}$ & & $10^{-10}-10^{-6}$ & $\angle \overline{\bar{\prime}} 0 \bar{T}$ \\
\hline
\end{tabular}

Order Gasterostei forwes

Fam. Gasterosteidae
Gasterosteus aculeatus
F ${ }^{3}$ H
0.5
$\{\overline{7} 17$

Order Cyprinodontiformes

Suborder Cyprinodontoidei

Fam. Cyprinodontidae

Fundulus heteroclitus

\begin{tabular}{lll} 
Feternal & $100-2000$ & {$[\overline{7} 2 \underline{T}$} \\
\hline Excernal & 2000 & $\lfloor\overline{7} \underline{3} \bar{T}$
\end{tabular}

\begin{tabular}{|c|c|}
\hline External & $1000-200000$ \\
\hline
\end{tabular}

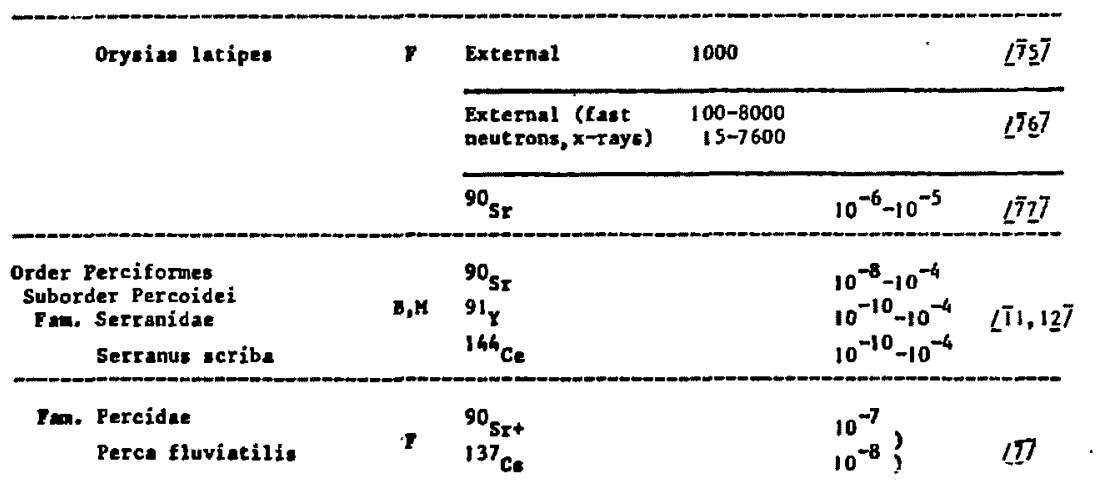




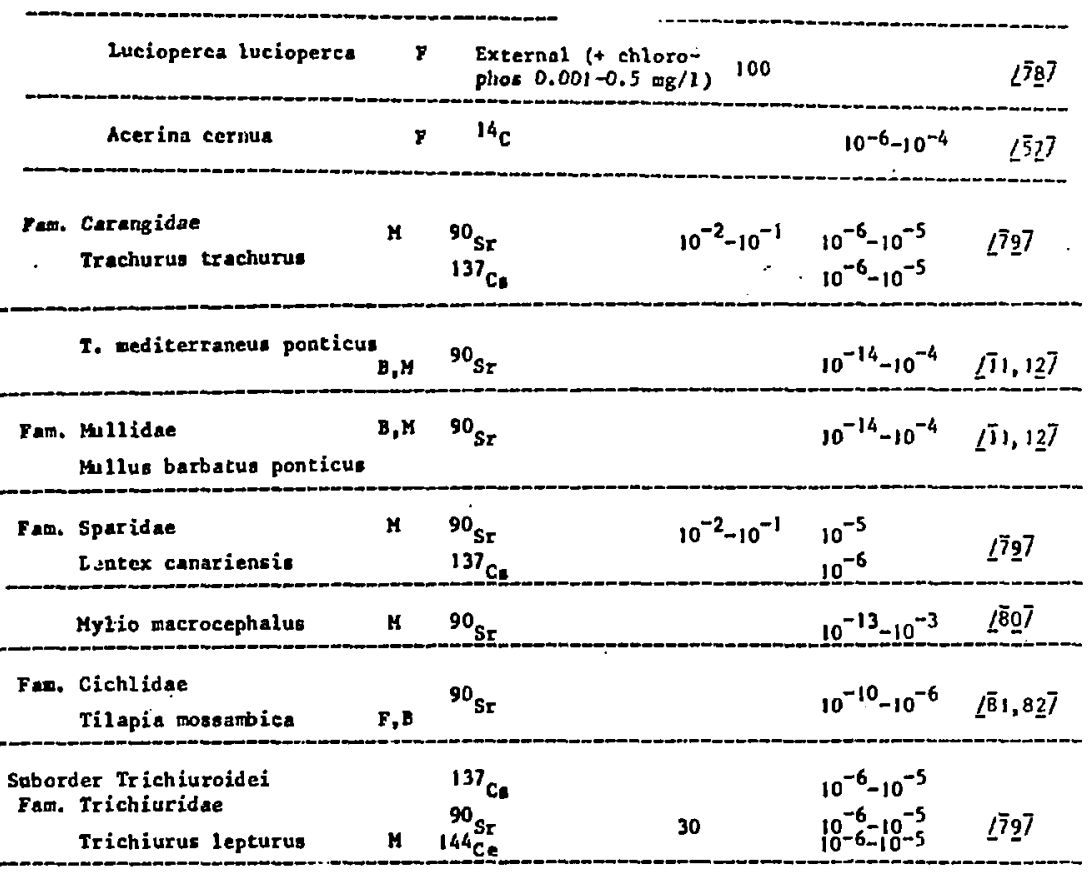

Suborder Gobioidei

Fam. Gobiidae

Neogobius melanostomus
B, $\quad{ }^{45} \mathrm{C}$.
$10^{-9}-10^{-5}$
[8.87

Suborder Cotcoidei

Eati. Scorpaenidae

Scorpaene porcus

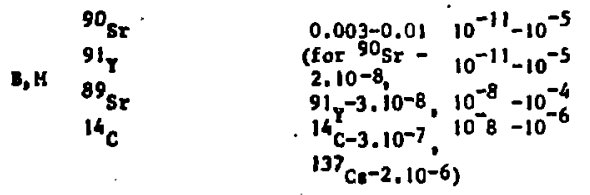

$91_{Y}$ (t strep-
tonicin)

$10^{-6}$

Suborder Anabantidoldei

Fan. Anabantidae

F External

$1000-5000$

Hacropodu: opercularia 


$\begin{array}{lll}\begin{array}{l}\text { Ordfr Plcuronectiformes } \\ \text { Fam. Bothidae }\end{array} & 91 \mathrm{y} & 10^{-8}-10^{-4} \\ \begin{array}{l}\text { Scophthalmus macoticus } \\ \text { macoticus }\end{array} & \text { B } 137 \mathrm{CE} & 10^{-4}\end{array}$
maeoticus

Far. Pleuronectidae

Pleuronectes platesse

M External 30-150

$[\bar{B} B \bar{Z}$

$\begin{array}{ll}90_{S r} & 10^{-11}-10^{-10} \\ 137 \mathrm{Cs} & 10^{-11}-10^{-10}\end{array}$

$\begin{array}{llll}{ }^{90} \mathrm{Sr} & 0.004-230 \\ & 0.63-492.5 & 10^{-10}-10^{-4} \quad[\overline{3} 3]\end{array}$

Paralichthy olivaceus $M \quad{ }_{H} \quad 10^{-6}-10$

Order Tetradontiformea

Faur. Munacanthidae

Rudario ercodes

M $\quad 90_{\mathbf{s r}}$

$10^{-13}-10^{-3}$

ட믁

Fam. Tetraodontidae

Fugu niphobles

\begin{tabular}{l}
$3 \mathrm{H}$ \\
\hline
\end{tabular}

x.

"If there is a seriec of publications, then the lagt and generalized one is being cited.

mExternal - gama or X-rays. If other external radiation. (neutrons, beta-part :eles),
they are specified. 


\section{Sourpe:}

lifec, T. $\Omega_{0}$ and D, A. Wolfe. 2972. Radioactivity - chemical and blolorical anpects. pp. 325-379. In: Implngement of Man on the Oceans. (D. H. Hood, cd.). Wilcy-Tnterscience, $\mathrm{KY}$.

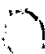

Table 12.10. Amounts of Radiation Required to Kill 50 Per Cent of the Rainbow Trout, Salmo gnirdneri, Irradiated at Various States in Their Lire Cycle .

\begin{tabular}{|c|c|}
\hline Stage in Life Cycle & LD. 00 (B) \\
\hline $\begin{array}{l}\text { Gamrted } \\
1 \text { cell } \\
\text { os cell. } \\
\text { Cem rims } \\
\text { Ese } \\
\text { Adult }\end{array}$ & $\begin{array}{l}60-100 \\
69 \\
313 \\
434-461 \\
415-904 \\
1400\end{array}$ \\
\hline
\end{tabular}


Sourco: Rzea, T. H, and J. P. Baptist, 197h. Chp. 10. Beolopic effects of

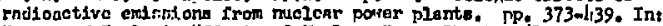
Hurean and Eoolorito Lifects of Muclear Power Plents. (L, A, Sagan, ed.). Charlou O Thomes, Springfield, II.

rABLE 10.XIII COMPARISON OF TIE RADIATION SENSITIYITIES OF, VAMIOUS AQUATIC ORGANISMS AS INDICATED $D$

\begin{tabular}{|c|c|c|c|c|c|c|c|}
\hline Spreik: & Hedialian & Dowe & Trep. & sel. & LD.so & Coso & Neference \\
\hline 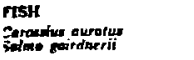 & $\begin{array}{l}x-\operatorname{cosy} \\
\mathbf{x} \cdot \mathbf{r n y}\end{array}$ & 1,000 & $\underline{2 x-25}$ & $\stackrel{-}{-}$ & $\mathbf{p}$ & $2315:$ & 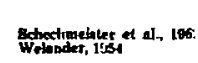 \\
\hline 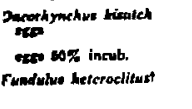 & $\begin{array}{l}x \cdot \pi y \\
x \cdot n y \\
\operatorname{enmmn}\end{array}$ & $460 \mathrm{rad} / \mathrm{min}$ & $\boldsymbol{1 1}$ & - & $\underset{0}{0}$ & 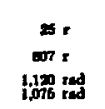 & 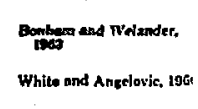 \\
\hline Mrupit orphefust & pand & n'م//der & $m$ & - & $\ddot{\infty}$ & $2,050 \mathrm{red}$ & Whilo and Anzelovic, ise \\
\hline Extroulenger ep.t & enme & nנm $40 \mathrm{red}$ & $\pi$ & - & $\underset{\infty}{\infty}$ & 850 meds & WhHte nond Angerlovic, 196 \\
\hline Intodon rhamboldent & Dhenema & $400 \mathrm{rad} / \mathrm{min}$ & 18 & - & $\mathbf{B}$ & $2,000 \mathrm{md}$ & Whito and Anpelovic, 196 \\
\hline Nikrepogen madubaturt & Imantix & $46 \mathrm{rad} / \mathrm{mm}$ & $\mathbf{w}$ & - & $\mathbf{\infty}$ & ded & White and Anjotowle, f \\
\hline muliekshy lethosticmel & andent & $400 \mathrm{nd} / \mathrm{min}$ & M & - & $\ddot{B}$ & ispos rod & Whilo and Angotovic, 196 \\
\hline $\begin{array}{l}\text { CRUSTACEA } \\
\text { OAG meru metimLe }\end{array}$ & $9+\pi$ & a vimin & to & 10 & $\boldsymbol{x}$ & $1,700 \mathrm{r}$ & Hoppombelt, IDO \\
\hline o. menthil & $m-m r$ & n & 15 & 10 & $\boldsymbol{0 0}$ & 1,700 & Ilopponheil, 1060 \\
\hline o. ducteal & xiny & $400 \mathrm{~s} / \mathrm{arat}$ & 16 & 10 & $\boldsymbol{*}$ & 200 I & Hoppenteil, 1800 \\
\hline C. durbent & $\mathbf{m}+\mathbf{m}$ & tos s/min & II & $\omega$ & $\boldsymbol{\omega}$ & $200 \mathrm{r}$ & Merpanheil, 1960 \\
\hline Paloemancter putio & $\operatorname{mon}$ & $1500 \mathrm{r} / \mathrm{min}$ & - & - & $\mathbf{m}$ & $1,465 \mathrm{P}$ & Rest, 1962 \\
\hline P. pugio & 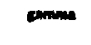 & $200 \mathrm{rad} / \mathrm{min}$ & $\boldsymbol{x}$ & 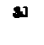 & $x_{010}^{20}$ & 7it6 net & S.C. White, unpublished \\
\hline Uen pumer & $\ln$ & $1960 \mathrm{r} / \mathrm{min}$ & - & $\bar{m}$ & $\mathbf{n}$ & 4000 r & $\operatorname{Rom}, 1962$ \\
\hline D. momar & $\min$ & $200 \mathrm{md} / \mathrm{m}$ & 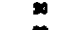 & $\boldsymbol{\infty}$ & $\omega$ & 1660 ind & D.W. Eaped, unpublished \\
\hline U. midider & $=$ & Mred/min & 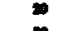 & 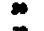 & $\omega$ & $9000 \mathrm{and}$ & 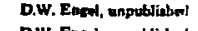 \\
\hline $\begin{array}{l}U, \text { mines } \\
\text { Cultinectes apriting }\end{array}$ & an & 20 red/aln & $\boldsymbol{\infty}$ & $\ddot{x}$ & $\omega$ & $\begin{array}{l}13,100 \mathrm{~m} \\
2000 \mathrm{mad}\end{array}$ & $\begin{array}{l}\text { D.w. Enywl, unpubliahed } \\
\text { Ewat, ing }\end{array}$ \\
\hline MOLLLU:CA & & & & & & & \\
\hline Lereemaris merernerit & $\operatorname{ang}$ & nem & - & - & 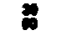 & $\operatorname{lus}_{\text {then }} \mathrm{r}$ & Prike, Itws \\
\hline Cranedres virglate & 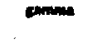 & 400 r/mis & - & - & 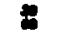 & $<00000$ : & Prist, Ises \\
\hline Austrabertis slotratus & 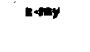 & 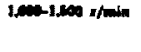 & - & $\bullet$ & & trip: & 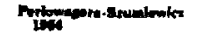 \\
\hline Unopiphr cinerese & $2-\boldsymbol{y}$ & - & - & - & 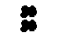 & ser: & 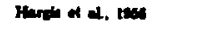 \\
\hline U. rineres & Iony & - & - & - & 6 & If: & Kenten of al, ins \\
\hline Nomerim eboolumer & م=سח & redingin & 10 & - & $\ddot{0}$ & tren & mite and Anoriowle, ith \\
\hline
\end{tabular}




\section{Source:}

Seymour, A, H. et al. 1975. Aquatic enviroment, pp. 103-161. In: Itong-Term Worldwide Effects of Yultiple Nuclear-Weapons Detonations. (Committee to Study the lone-Lerm Horldwide Erfects of Multiple Nuclear-Heapons Detonations). National Research Counc17, National Acadeny of Sciences, Washington, DC.

TABLE 4.9 Ranges of Acute Lethal Radiation Doses for Various Groups (kilorads) $^{a}$

\begin{tabular}{lc}
\hline Organisn & Radiacion Doge \\
\hline Bacteria & $4.5-735\left(L D_{90}\right)$ \\
Blue-green algae & $<400-1200\left(L D_{90}\right)$ \\
Other al gae & $3-120\left(L D_{50}\right)$ \\
Protozo: & $1-600\left(L D_{50}\right)$ \\
Mollusks & $20-109\left(L_{50 / 30}\right)$ \\
Cruataceans & $1.5-14.5\left(L D_{50 / 30}\right)$ \\
Fish & $1.1-5.6\left(L D_{50 / 30}\right)$ \\
\hline
\end{tabular}

From Reference 71 . 


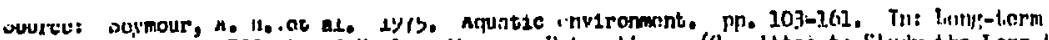

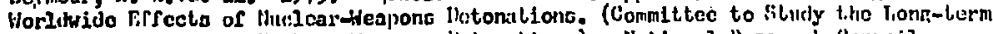

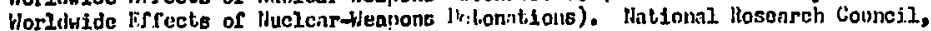
National Acadens of Sciences, Waohinition, DC.

TÁbi. A.15 Est imated Whole-Body Radiation Doses to Selected Blota, mrad/year

Type Internal External Total

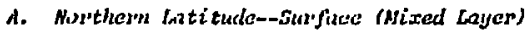

\begin{tabular}{|c|c|c|c|}
\hline $\begin{array}{l}\text { Fisli } \\
\text { trustaceil } \\
\text { Hillusks } \\
\text { Plants } \\
\text { Bird (plant dlet) } \\
\text { Bird (flsil dlet) }\end{array}$ & $\begin{array}{l}0.8 \\
2 . \\
2 . \\
10 . \\
\text { so. } \\
4 .\end{array}$ & $\begin{array}{c}0.01^{a} \\
70.1 \\
70.1 \\
0.04^{a} \\
-0.007^{\circ} \\
-0.007^{\circ}\end{array}$ & $\begin{array}{c}0.8 \\
70 . \\
70 . \\
10 . \\
50 . \\
4 .\end{array}$ \\
\hline
\end{tabular}

B. Northern Latitude--Midicpth

$\begin{array}{llcc}\text { Flsh } & 0.3 & 0.005 & 0.3 \\ \text { Crustacea } & 1 . & 30 . & 30 . \\ \text { Holiukss } & 1 . & 30 . & 30 . \\ \text { Algae } & 8 . & 0.01 & 8 .\end{array}$

c. Northern Latitude--Deep Water

$\begin{array}{lccc}\text { Fish } & 0.4 & 0.006 & 0.4 \\ \text { Crustacea } & 1 . & 30 . & 30 . \\ \text { Hollusks } & 1 . & 30 . & 30 . \\ \text { Algae } & 20 . & 0.02 & 20 .\end{array}$

D. Southem Latitudi--Surface (Mixed Layer)

$\begin{array}{lccc}\text { Finh } & 0.4 & 0.006 & 0.4 \\ \text { Crustacea } & 1 . & 30 . & 30 . \\ \text { Hullutks } & 1 . & 30 . & 30 . \\ \text { Hlants } & 16 . & 0.02 & 16 . \\ \text { Mird (plant diet) } & 20 . & 0.003 & 20 . \\ \text { Mird (fish diet) } & 2 . & 0.003 & 2 .\end{array}$

B. Southem Latitude-Niddepth

$\begin{array}{llll}\text { Tish } & 0.08 & 0.001 & 0.08 \\ \text { Crustacea } & 0.3 & 7 . & 7 . \\ \text { Molluaks } & 0.3 & 7.003 & 7 . \\ \text { Plent: } & 2 . & 0.003 & 2 .\end{array}$

F. Southasm Latitud('--lece) Water

\begin{tabular}{llll} 
Prah & 0.05 & 0.0008 & 0.05 \\
Crustacea & 0.2 & 5. & 5. \\
Molluaks & 0.2 & 2. & 2. \\
Plents & 1. & 0.002 & 2. \\
\hline
\end{tabular}

Gxternal dose from watur Immereson.

Exterial dasa at water-wedimilic linter fuce.

Imerulon dose $2650 \%$ of tIme is apent in water. 


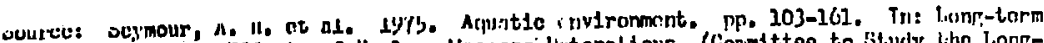

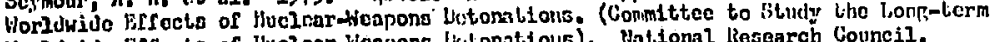

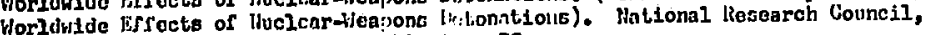
National Acadeng of Sciences, Washinfiton, DC.

TABLE 4.16 Estimated Radiacion Doses to People Consuming Seafood, aren/year ${ }^{a}$

Food Totol Body $\quad$ Gl-LLI ${ }^{b}$ Tliyrold Bone $^{c}$

Hervested from:

A. Northem Hemiaphere--Surface (Nixed Iayen)

$\begin{array}{lllll}\text { FIsh } & 0.06 & 0.06 & 0.9 & 0.07 \\ \text { Crustacea } & 0.008 & 0.02 & 0.4 & 0.009 \\ \text { Hollusk: } & 0.004 & 0.03 & 0.8 & 0.005 \\ \text { TOTAL } & 0.07 & 0.1 & 2 . & 0.08 \\ \text { So-yr dosed } & 4 & 5 & 100 & 4\end{array}$

B. Northem Hemisphere--Niddepth

\begin{tabular}{lllll} 
Fish & 0.02 & 0.02 & 0.3 & 0.03 \\
Cruataces & 0.005 & 0.006 & 0.1 & 0.004 \\
Holluske & 0.002 & $\underline{0.01}$ & $\underline{0.3}$ & 0.003 \\
\hline TUTAL & 0.03 & 0.04 & 0.7 & 0.04
\end{tabular}

6. Northerm Hemiophure--Deep Water

$\begin{array}{lllll}\text { Fish } & 0.03 & 0.03 & 0.4 & 0.03 \\ \text { Crustace } & 0.04 & 0.007 & 0.2 & 0.005 \\ \text { Hollusks } & 0.04 & \underline{0.015} & \underline{0.4} & \underline{0.0004} \\ \text { Total } & 0.1 & 0.05 & 1.0 & 0.04\end{array}$

D. Southem Hemiophalc-Surface (Mixed Layer)

$\begin{array}{cllll}\text { Fish } & 0.03 & 0.02 & 0.4 & 0.03 \\ \text { Crustacea } & 0.003 & 0.007 & 0.2 & 0.004 \\ \text { Hollusks } & \underline{0.002} & \underline{0.01} & \underline{0.4} & \underline{0.002} \\ \text { Total } & 0.04 & 0.04 & 1.0 & 0.04\end{array}$

c. Southorn Homiephere--Widdepth

$\begin{array}{lllll}\text { Fish } & 0.005 & 0.006 & 0.09 & 0.007 \\ \text { Crustaces } & 0.0008 & 0.002 & 0.04 & 0.0009 \\ \text { Holluake } & 0.0004 & \underline{0.003} & 0.08 & \frac{0.0005}{0.008} \\ \text { Torat } & 0.006 & 0.01 & 0.2 & 0.008\end{array}$

F. Sou them Homiophare--Dacp Water

\begin{tabular}{|c|c|c|c|c|}
\hline $\begin{array}{l}\text { Flalt } \\
\text { Crustacta } \\
\text { Holluake }\end{array}$ & $\begin{array}{l}0.0015 \\
0.1 \mathrm{kM15} \\
0.0002\end{array}$ & $\begin{array}{l}0.004 \\
0.011 \\
0.002 \\
\end{array}$ & $\begin{array}{l}0.06 \\
0.02 \\
0.05\end{array}$ & $\begin{array}{l}0.004 \\
0.0101 \\
0.0004\end{array}$ \\
\hline TOTAL & 0.004 & 0.007 & 0.1 & 0.005 \\
\hline
\end{tabular}

apocse are rounded of co avold sugesetsns undue accuracy.

Encrance to lower large inteetine.

Mineral bone.

Woes accumulated over a 50-year period from continuous ingestion of contamineced seafood at the acm concentrations as the ifrat year. 
Source: Templeton, H. I., R. F. Nakatant and F. F. fleld, 1971. Nadiation esfects. ip. $r 23-$ 239. In: lladionctivity in the Marino Finvironert. (Panel on Marine lidioactivity in tho Harine Environent). National Acadeny of Sciences, Gashingtion, DC.

(Gadus acgiefinisis);

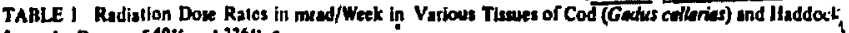
from the Decay of ${ }^{40} \mathrm{~K}$ and $226 \mathrm{Ka}^{4}$

\begin{tabular}{|c|c|c|c|c|c|c|c|}
\hline & & \multicolumn{4}{|l|}{ Cod } & \multicolumn{2}{|c|}{ Madoct } \\
\hline \multicolumn{2}{|c|}{ Rediomatile } & Tisede & stia & Bon & $F$ & Mroste & sin \\
\hline $\mathbf{4}$ & 7 & $\begin{array}{l}0.43 \\
0.03\end{array}$ & $\begin{array}{l}0.23 \\
\therefore .01\end{array}$ & $\begin{array}{l}0.21 \\
0.01\end{array}$ & $\begin{array}{l}0.15 \\
0.01\end{array}$ & $\begin{array}{l}0.35 \\
0.03\end{array}$ & $\begin{array}{l}0.25 \\
0.01\end{array}$ \\
\hline $226 \mathrm{na}$ & & - & 0020 & 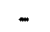 & - & - & 0.040 \\
\hline
\end{tabular}

Arict Frener (1065).

TABLE 2 Eutmutes of Naturd-Radiation Done Rafes to

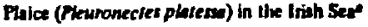

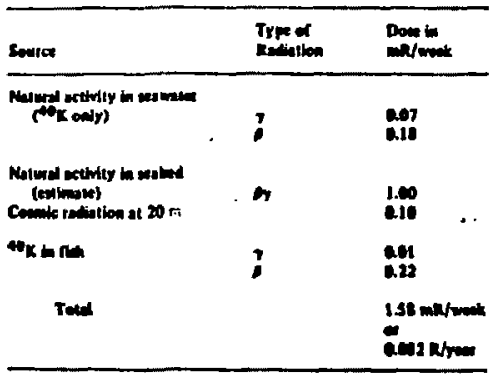

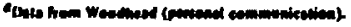


Source: Toytsugina, v. G., N. S. Risik and G. D. Lazorenko. 1975. Chp. II. Karyoj.oiy of marine fish and the effect of radionuclicics on their chromosome apparatus. pp. 16 - 39. In: hrtificial and latural Radioneclideo in llarine Iiffe. "Naukova Dumka", Kiev. (Enqlish transl. TT 75-50010, U. S. Dopt. of Commerce, National Technical Information Service).

Chronfe offect of lon doses of incorporated radiomuclides on the chramosone apparatus of aninals and plants (the excess over and above, the absorbed dose oupplied by cosmic radiation is indicated in parentheses).

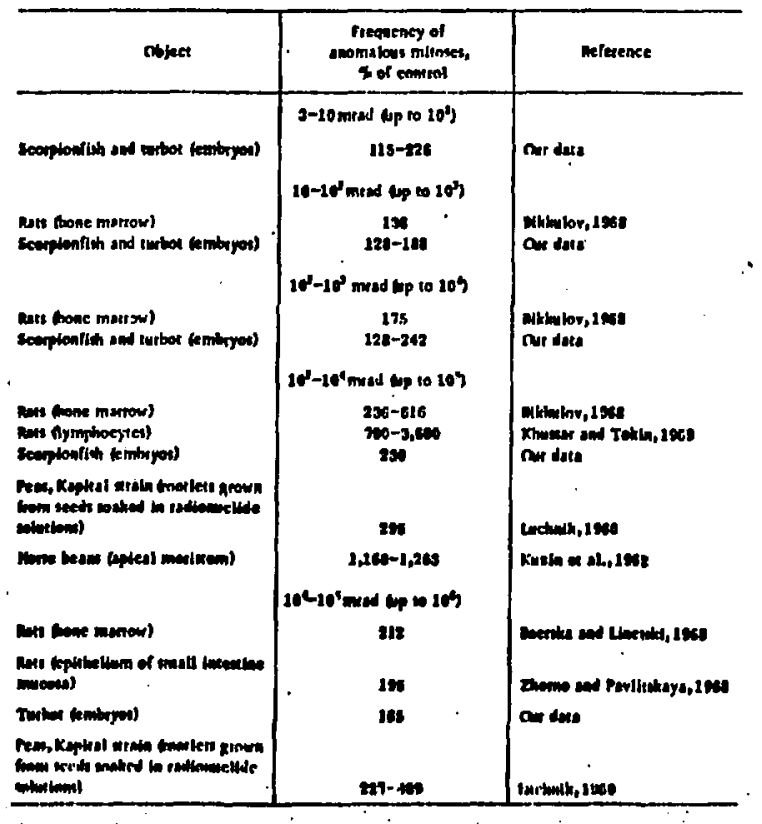


Source: Trytsugina, V. G., N. S. Risik and G. T. Lazorenko, 2975. Chp. II. Karyolocy of narine litih and the effect of radionuclides on their chromosome apparatus, pp. 16 - 39. In: Artificial and Natural Radionuclides in Harine Life. "Haukova Dumka", Kiev.

(Enclish transl. TT 75-50010, U. S. Dept. of Commerce, National Technical Infornation Service).

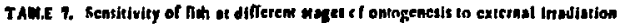

\begin{tabular}{|c|c|c|c|}
\hline speeks & Buse, & efreet & Deference \\
\hline 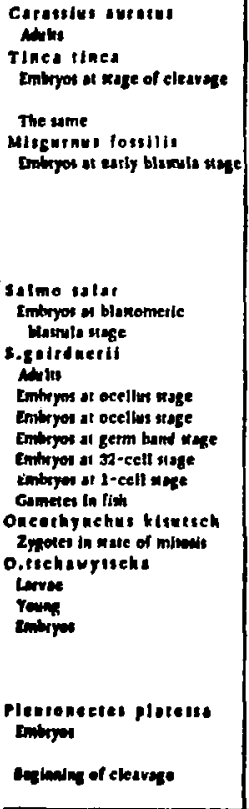 & 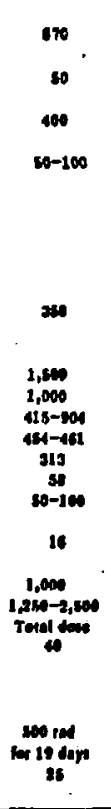 & 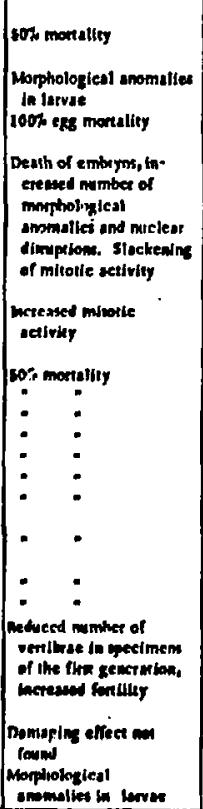 & 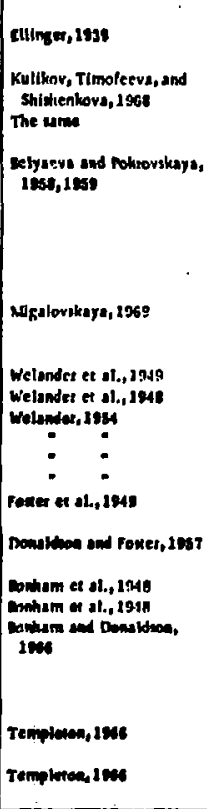 \\
\hline
\end{tabular}


Source: TBytsupina, V. O., N. S. RIElk and G. E. Lazorenko, 1975. Chp. II. Karyolopy of marine lish and the effect of radionuclides on their chromosome apparatus. pp. 16-19. In: Artificial and Natural Radiomulides in harine Life. "Naukova Dunka", Kiev.

(Enclish transi. TT 75-50010, U. S. Dept. of Commerce, National Technical Information Service).

TAME A. Serallivily of fish embrym tn incorgme ited radionactides

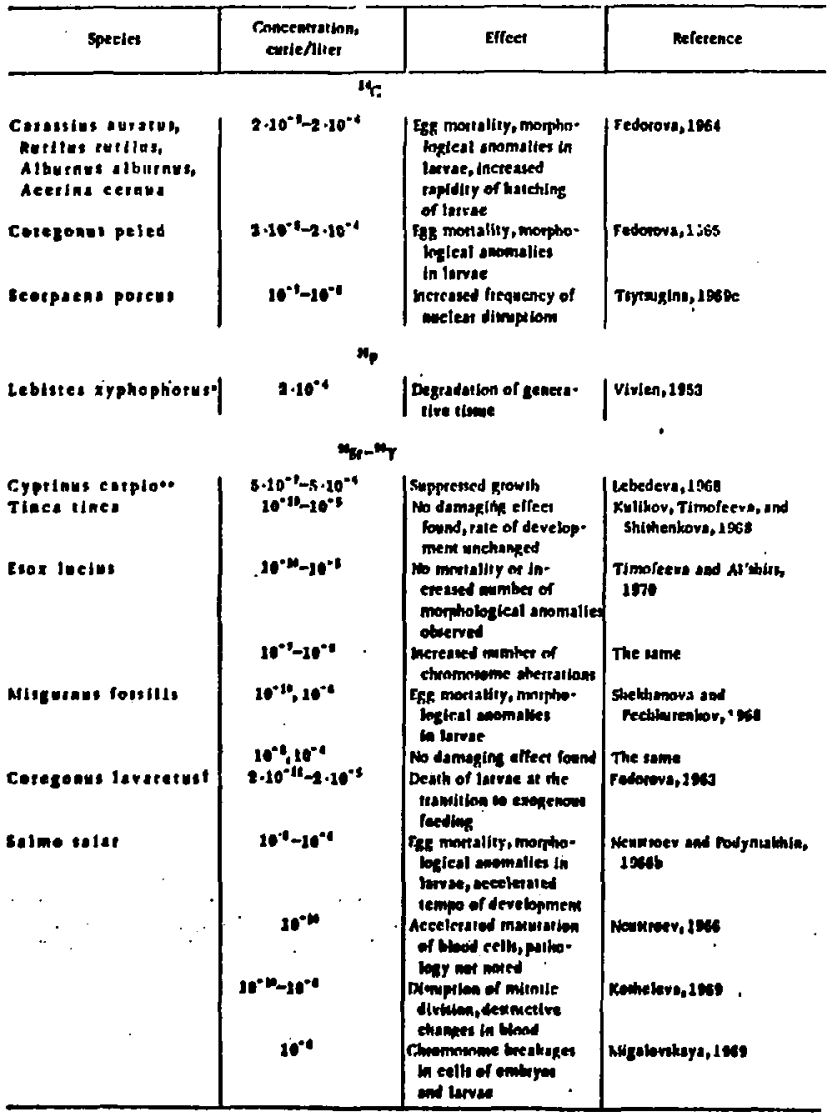

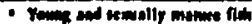

- Yomatelotheryen

1 lewe 
Tabj.c \& contimed.

Sourca: Tsytsugrina, V. G., N. S. Risik and G. E. Lazorenko, 1975. Cing. II. Karyolow of marino fish and the effect of radionuclices on thoir chrumosonic apparatus. pp. 16-19. Is: Artificial and Natural lidiomclidea in Narine Life. "Naukova Dumka", Kiev. (English transl. TT 75-50010, U. S. Dept. of Commerce, National Techical Information Service).

TAbL : (conilined)

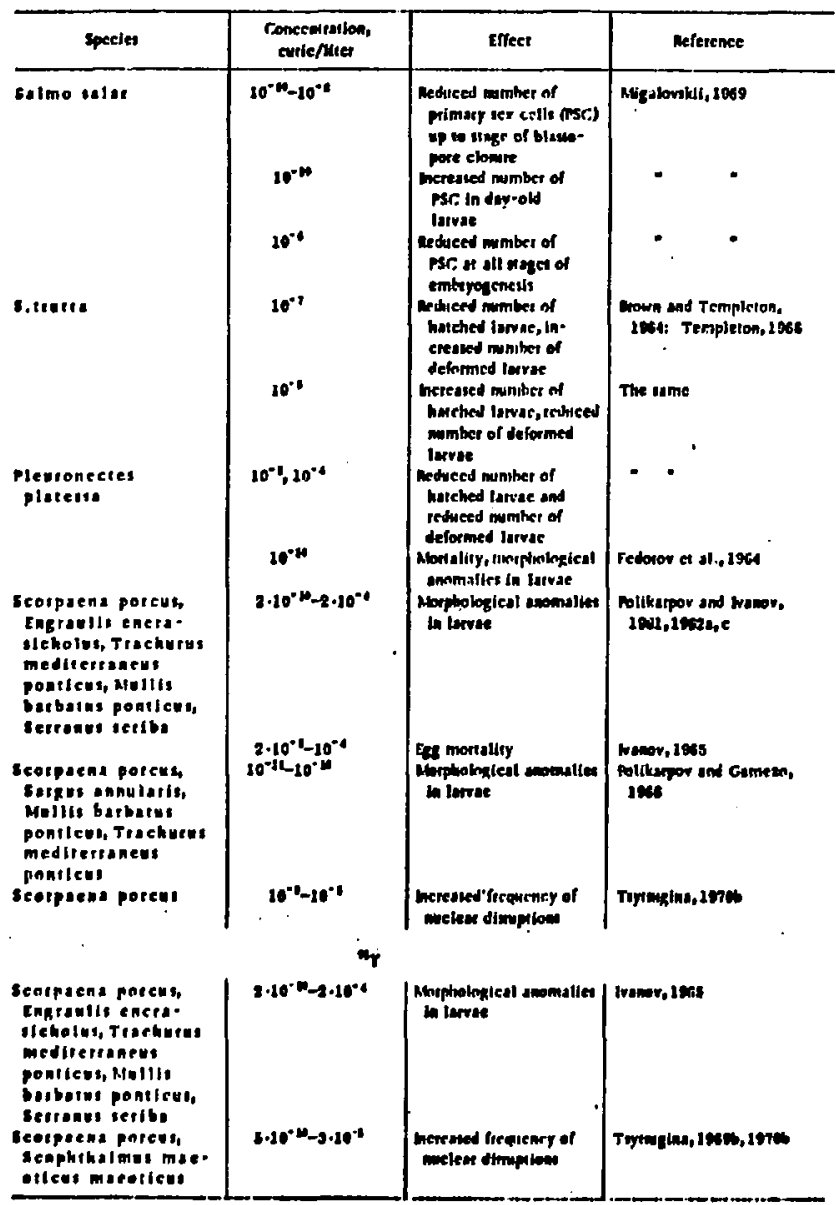


Tablo 8 contimed.

Source: Teytsugina, V. G., N. S. Risik and G: E. Lazorenko, 1975. Chp, II. Karyoloby of marine fish and the effect of radionuclides on their chromosome apparetus. pp. 16-19. In: Artificial and Natural Radiomejides in Jierine Life. "Naukova Dumka", Kiev, (Inglish transl. TT 75-50010, U. S. Dept. of Commerce, llational Technical Information Service\}.

TAW, 8 contimes)

\begin{tabular}{|c|c|c|c|}
\hline Species & $\begin{array}{l}\text { Concemistion, } \\
\text { corlefhitot }\end{array}$ & Lifet & Meference \\
\hline \multicolumn{4}{|c|}{${ }^{\prime c a}$} \\
\hline 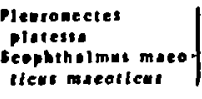 & $\begin{array}{c}10^{-11} \\
20^{-6}-10^{-8}\end{array}$ & 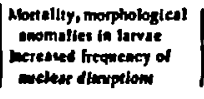 & $\begin{array}{l}\text { Fedorow et al., } 1964 \\
\text { Toynu gina, 1959e }\end{array}$ \\
\hline \multicolumn{4}{|c|}{ Mre } \\
\hline 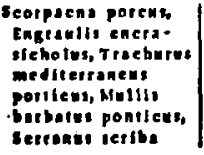 & $10^{-30}-10^{-4}$ & $\begin{array}{l}\text { Morphological anomalies } \\
\text { in lurvese }\end{array}$ & Iuanov, 1*ss \\
\hline \multicolumn{3}{|c|}{ Extroet of radiosective abh } & - \\
\hline $\begin{array}{l}\text { Pseederasters parva } \\
\text { parva }\end{array}$ & $10^{*}$ & 140r larval morratity, & futhya and rast, Lest \\
\hline \multicolumn{4}{|c|}{ Redieavellde mixtere of unknewn cempetition } \\
\hline zebre danie & $\begin{array}{l}5.1+10^{+1} \\
4.10^{-10}\end{array}$ & 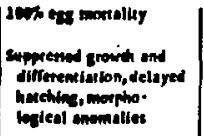 & $\begin{array}{l}\text { Mhand, Wranals ond } \\
\text { Tahom, ises } \\
\text { The ume }\end{array}$ \\
\hline
\end{tabular}




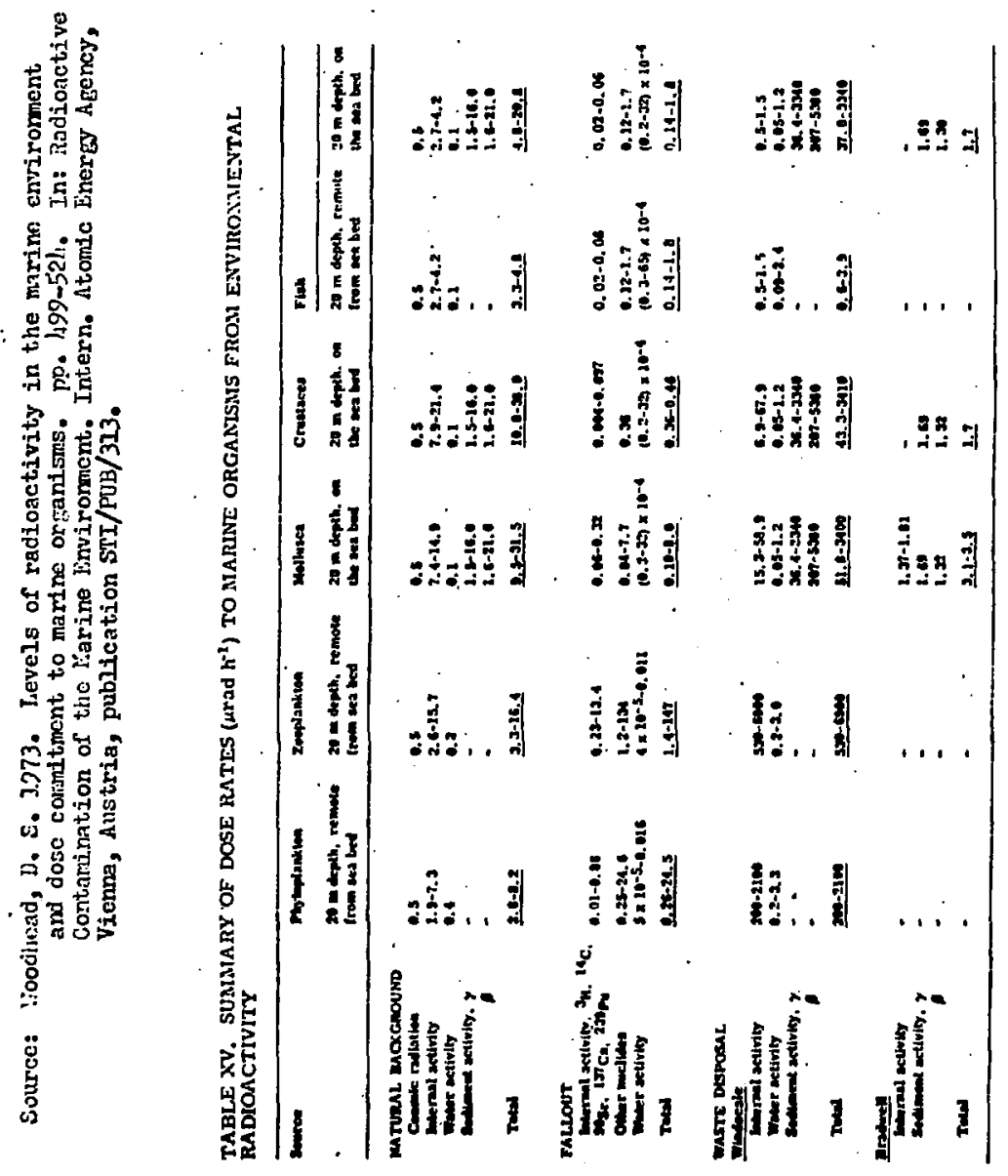


Soirce: Seymour, A. Il. ot al. 1975. Aquitio environment, pp, 103-161. In: Lonp-term Vorldwide fiffects of liucleandieapons Detonitions. (Comittec to Stidy the Lonf-term Worlivido firfecto of lluclanr-lieapons Detonitions). National Resoarch Council, Hational Acadeny' of Sciences, Washinpton, DC.

TABle 4.10 Comparison of the Radiation Sensteivitfes of Varlous Aquatic Organians ac Indicated by Liathel Doses ${ }^{a}$

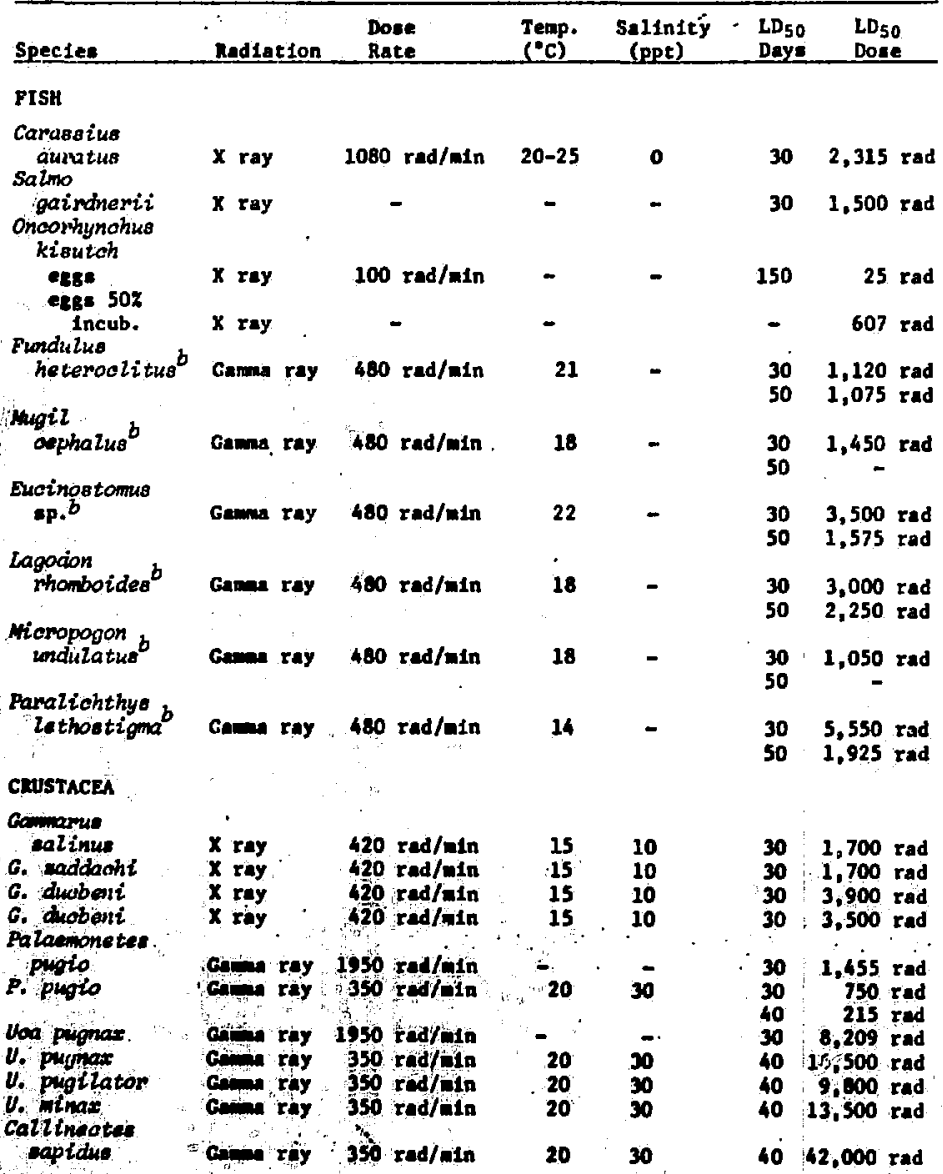


Table h.10. contimued.

Source: Seymour, A. H. et al. 2975. Aquatic envirobment, pp, 103-16]. In: Long-tem l:orlunlde Effects of huclear-:capons jetonations. (Committee to Stucy the Jone-term :Iorlsivie E: Secte of Hucloarditeapons Detonstions). Nation?l leseerch Council, National Acadomy of Sciences, Vashington, DC.

\begin{tabular}{|c|c|c|c|c|c|c|}
\hline Spectes & Radjation & $\begin{array}{l}\text { Dose } \\
\text { Rate }\end{array}$ & $\begin{array}{l}\text { Temp. } \\
\left({ }^{\circ} \mathrm{c}\right)\end{array}$ & $\begin{array}{c}\text { Salinity } \\
\text { (ppt) }\end{array}$ & $\begin{array}{l}L_{50} \\
\text { Days } \\
\end{array}$ & $\begin{array}{l}L_{50} \\
\text { Dose }\end{array}$ \\
\hline wot.L.USs:A & & & & & & \\
\hline $\begin{array}{l}\text { Mertistlaria } \\
\text { mercenaria }\end{array}$ & Gamma ray & $5800 \mathrm{rad} / \mathrm{min}$ & - & - & $\begin{array}{l}30 \\
60\end{array}$ & $\begin{array}{r}115,000 \\
67,000\end{array}$ \\
\hline $\begin{array}{l}\text { Crassostrea } \\
\text { vilyinica }\end{array}$ & Gamma ray & $5800 \mathrm{rad} / \mathrm{m} 1 \mathrm{n}$ & - & - & $\begin{array}{l}30 \\
60\end{array}$ & $\begin{array}{l}100,000 \\
<10,000\end{array}$ \\
\hline $\begin{array}{c}\text { Australaibis } \\
\text { ylabratus }\end{array}$ & $X$ ray & $1000-1500 \mathrm{rad} / \mathrm{m} 1 \mathrm{n}$ & - & 0 & $\begin{array}{l}30 \\
60 \\
90\end{array}$ & $\begin{array}{l}23,800 \mathrm{r} \\
16,300 \mathrm{r} \\
13,800 \mathrm{r}\end{array}$ \\
\hline $\begin{array}{l}\text { Urosalivinx } \\
\text { cinereu }\end{array}$ & $x$ ray & - & - & - & $\begin{array}{l}30 \\
60\end{array}$ & $\begin{array}{l}40,000 \\
20,000 r\end{array}$ \\
\hline U. cinerea & $x$ ray & - & - & - & $\begin{array}{l}30 \\
60\end{array}$ & $\begin{array}{l}47,000 \mathrm{r} \\
32,000 \mathrm{r}\end{array}$ \\
\hline $\begin{array}{l}\text { Nassarius } \\
\text { obsoletus }\end{array}$ & Gamma ray & $480 \mathrm{rad} / \mathrm{min}$ & 18 & - & $\begin{array}{l}30 \\
50\end{array}$ & $\begin{array}{l}37,500 \\
14,000\end{array}$ \\
\hline
\end{tabular}

Data from Reference 34. (Bice, T. $r$, and J. P. Baptist, 1974)

Imature stage. 
SEIECTED BIBLIOGRAPHIES ON

BIOLOGICAL EFFECTS OF IONIZING RADIATION

by

Vincent Schultz

Department of Zoology

Washington State University
Pullman, Washington 99164

1979 
Anonymous, 1978. Low-level radiation, Biological interactions, risks, and benefits. A biblioeraphy. $U$. S. DOZ report TID-3373. iv, $513 \mathrm{pp}$. plus index of $218 \mathrm{pp}$.

Bost, W. E., H. L. Ward and H. E. Voress. 1967. Combined subject and author indexes to radiobiology biblioEraphies. TID -3097, Biological effects of ionizing radiation and TID-3098. The effects of radiation and radioisotopes on the life processes. U. S. AIC report TID-3099, iii, 762 pp.

Ingram, it. 1966. Biological effects of ionizing radiation. An annotated bibliography covering the years 18981957. U. $\Xi$. AEC report TID-3097, viii, 892 pp.; index vi⿺辶, $286 \mathrm{pp}$.

Iangham, W. H. (ed.), P. Bell, I. Codfrey and H. Stearns (comps.). 1960. Literature search on the relative biological effectiventes (RBE) of lonizing radiations. Los Alamos Jeientific Lab., U. $S$. AEC report LAlls2343. $251 \mathrm{pD}$. (NiA 14-25216).

Fhillips, $\therefore$. D. and bi. G. Nagelsen. 1951. A bibliography on the effects of x-rays on bacteria. Battelle liemorial Institute, Columbus, Ohio. $18 \mathrm{py}$. (NP-3610). (NiA 6-1377).

Fierce, C. Li. 1963. The effects of radiation and radioisotopes on the life processes. An annotated bibliozraphy. Beuk 1, 2. U. S. AEC report TID-3098, viii, $1824 \mathrm{pp}$. (Index by Bost, W. E.. H. L. Ward and H. E. Voress).

kobinson, K. F., fi. D. Fhillips and W. G. Nagelsen. 1951. A bibliography of the effects of $x$-rays on bacteria. Oberlin College. $18 \mathrm{pp}$. (NP-3610). (NSA 6-1377).

Smith, I. I. 1961. Aleae, Radioactivity uptake irradiation effects, a literature search. I. I. dupont de Nemoure and Co., Savannah River Lab., v. S. AEC report PID-11749. 4 pp. (NSA 15-8504). 